\title{
Report of the DOE Advanced Fuel-Cell Commercialization Working Group
}

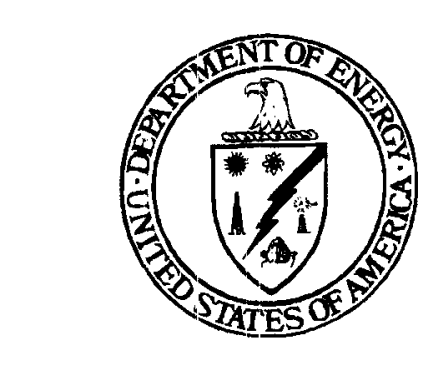

\section{March 1995}

U.S. Department of Energy Office of Energy Research Office of Program Analysis 
This report has been reproduced directly from the best available copy.

Available to DOE and DOE Contractors from the Office of Scientific and Technical Information, P.O. Box 62, Oak Ridge, TN 37831; prices available from (615) 576-8401.

Available to the public from the U.S. Department of Commerce, Technology Administration, National Technical Information Service, Springfield, VA 22161, (703) 487-4650. 


\section{DISCLAIMER}

This report was prepared as an account of work sponsored by an agency of the United States Government. Neither the United States Government nor any agency thereof, nor any of their employees, makes any warranty, express or implied, or assumes any legal liability or responsibility for the accuracy, completeness, or usefulness of any information, apparatus, product, or process disclosed, or represents that its use would not infringe privately owned rights. Reference herein to any specific commercial product, process, or service by trade name, trademark, manufacturer, or otherwise does not necessarily constitute or imply its endorsement, recommendation, or favoring by the United States Government or any agency thereof. The views and opinions of authors expressed herein do not necessarily state or reflect those of the United States Government or any agency thereof. 


\section{DISCLAIMER}

Portions of this document may be illegible in electronic image products. Images are produced from the best available original document. 


\section{Report of the \\ DOE Advanced Fuel-Cell \\ Commercialization \\ Working Group}

(referred to as AFC2WG or Working Group)

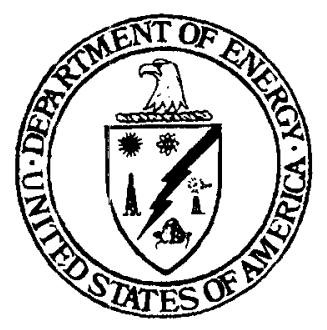

March 1995

Submitted by: S.S. Penner Center for Energy and Combustion Research University of Califomia, San Diego 9500 Gilman Drive

La Jolla, CA 92093-0411

Phone: (619) 534-4284

FAX: (619) 534-5354

Work performed under U.S. DOE Grant No. DEFG03-93ER30213 to the Regents of the University of California. F.D. Freeburn served as the DOE Technical Project Officer.

U.S. Department of Energy

Office of Energy Research

Office of Program Analysis

Germantown, MD 20874 



\section{REPORT \\ of the \\ DOE ADVANCED FUEL-CELL COMMERCIALIZATION WORKING GROUP* \\ (referred to as AFC2WG or Working Group) \\ January 30, 1995}

Submitted by: S.S. Penner Center for Energy and Combustion Research University of California, San Diego 9500 Gilman Drive

La Jolla, CA 92093-0411

Phone: (619) 534-4284

FAX: (619) 534-5354

* Work performed under U.S. DOE Grant No. DEFG03-93ER30213 to the Regents of the University of California. F.D. Freeburn served as the DOE Technical Project Officer. 


\section{TABLE OF CONTENTS}

PREFACE

V

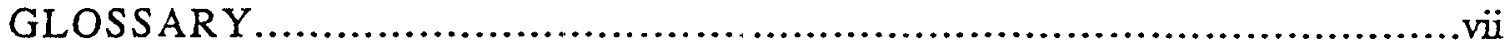

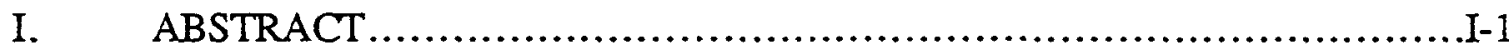

APPENDIX IA: MEMBERS AND EX OFFICIO MEMBERS OF THE DOE ADVANCED FUEL-CELL COMMERCIALIZATION WORKING GROUP

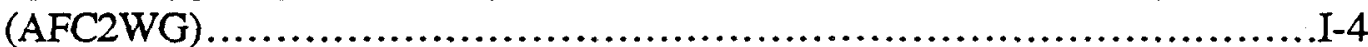

IN MEMORIAM: Manville J. Maytield .......................................I-9

II. STATUS AND DEVELOPMENT OF FC SYSTEMS ........................II-1

III-1. Introduction............................................................

III-2. Low-Temperature Systems (PAFCs and PEMFCs) ...........................

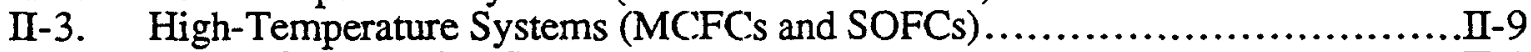

III-4. Power-Conditioning Systems .............................................. 15

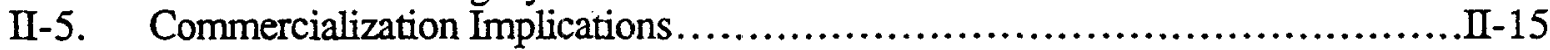

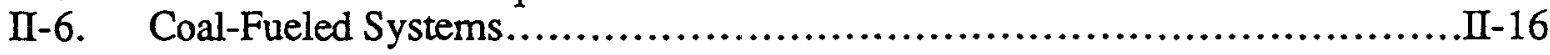

APPENDIX IIA: PROPOSAL FOR CONSTRUCTION AND OPERATTON OF A NATIONAL FUEL CELL RESEARCH CENTER (NFCRC)......................II-17

III. INTERNATIONAL PERSPECTIVES ON SUCCESSFUL FC-SYSTEM COMMERCIALIZATION .................................................

III-1. Private- and Public-Sector Commercialization of FC Systems.................III-1

III-2. The Importance of Timing in Commercialization Schedules......................III-2

III-3. Servicing FC Systems at User Installations .....................................

III-4. International Cooperation and Competition........................................

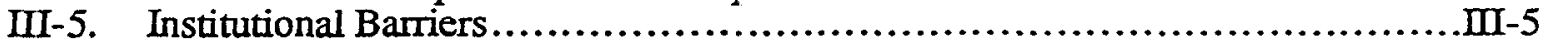

III-6. International Issues Relating to the Commercialization of New Technologies ....III-5

III-7. Steps in FC Commercialization ...............................................

III-8. FC-System Commercialization in Japan and Europe ..........................II-8

III-9. Strengths and Weaknesses of the U.S. Fuel-Cell Commercialization Effort .....III-12

APPENDIX IIIA: A HISTORICAL OVERVIEW OF PAFC DEVELOPMENTS AND COMMERCIALIZATION IN THE U.S., EUROPE AND JAPAN..............II-16

IIIA-1. Introduction...................................................................

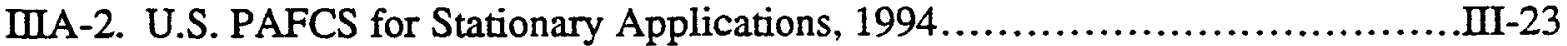

IIIA-3. European Dispersed-Power Applications of PAFCs .........................II-25

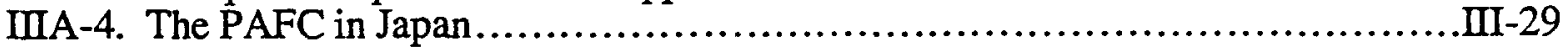


IV. MARKET PERSPECTIVES ON FC-SYSTEM COMMERCIALIZATION .....IV-1

IV-1. Competing Technologies................................................

IV-2. Estimations of Market Size ......................................................

IV-3. External Drivers in Commercialization ..........................................

IV-4. Measures to Accelerate Market Penetration .................................... IV-5

IV-5. Allocation of Funds for Commercialization through Market Push...............IV-6

V. MANUFACTURERS' PERSPECTIVES ON FC-SYSTEM COMMERCIALIZATION ..................................................V-1

V-1. Overview............................................................

V-2. AlliedSignal Recommendations for a Major New Initiative to Develop

Monolithic or Planar SOFC Technology for American Industry.................V-2-1

V-3. The Ballard PEM Fuel Cell Commercialization Program ........................ V-3-1

V-4. The Ceramatec/SOFCo SOFC Power Generation Systems: Development and

Commercialization .........................................................V-4-1

V-5. The Dow/Ballard PEM Fuel Cell System Development and Commercialization Programs...............................................................V-5-1

V-6. Energy Research Corporaton Perspectives on Fuel-Cell System

Commercialization ...................................................V-6-1

V-7. IFC Perspective on Fuel Cell System Commercialization............................. V-7-1

V-8. Commercialization of M-C Power's IMHEX Molten Carbonate Fuel Cell Power Plants ..................................................... $-8-1$

V-9. The Westinghouse View of SOFC-System Commercialization (Tubular SOFCs) ..........................................................

V-10. Ztek Advanced Planar RTI ${ }^{\circledR}$ SOFC for Efficient and Cost-Effective Utility Power Plants .............................................................

VI. ROLES OF DOE, EPRI AND GRI IN FC-SYSTEM COMMERCIALIZATION

VI-1. The Historical Role and Current Programs of DOE ..........................VI-3

VI-2. The Historical Role and Current Programs of EPRI.................................VI-8

VI-3. The Historical Role and Current Programs of GRI.............................VI-10

VII. IMPACTS OF PUBLIC POLICY AND REGULATIONS ON FC-SYSTEM

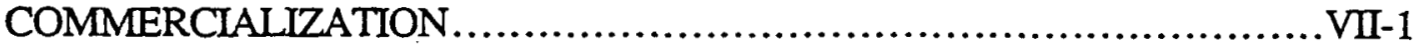

VII-1. Implications of Utility Deregulation on FC-System Commercialization...........VII-1

VII-2. Environmental Policy as a Driver for FC-System Commercialization.............. VII-3

VII-3. Selective Tax Relief to Target Specialty Markets................................... VII-4

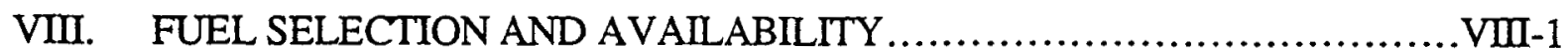

VIII-1. Costs and Availability of NG ................................................VIII-1 VIII-2. Use Rate of NG with Developing FC Capacity for Electricity Generation........VIII-3 
IX. NEAR-, INTERMEDIATE- AND LONG-TERM SUPPORTING R\&D TO REDUCE SYSTEM COSTS AND IMPROVE PERFORMANCE...............IX-1

IX-1. Research to Make Better and Cheaper PAFC Systems .........................IX-1

IX-2. Research to Make Better and Cheaper MCFC Systems .....................X. 18

IX-3. Research to Make Better and Cheaper SOFC Systems .....................X-40

IX-4. Supporting Research to Make Better and Cheaper PEMFC Systems...............IX-51

APPENDIX IXA: A RETROSPECTIVE OVERVIEW OF FC-TECHNOLOGY DEVELOPMENTS ....................................................

IXA-1. FC Technologies, 1985-1994 .............................................

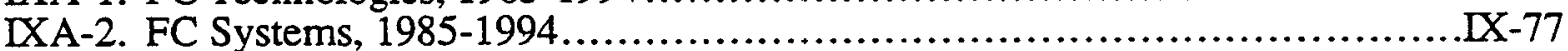

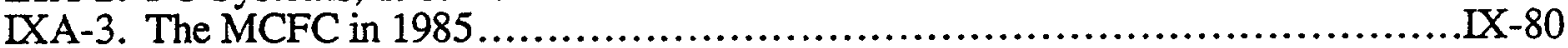

IXA-4. The MCFC and SOFC in the U.S. and Europe, 1985-94 ......................X-83

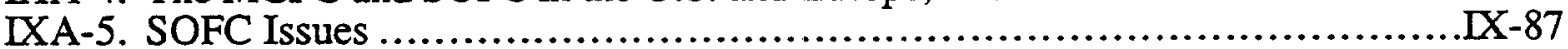

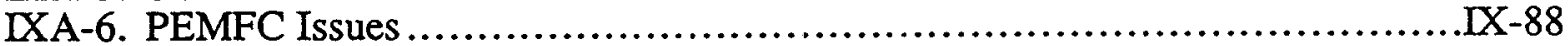

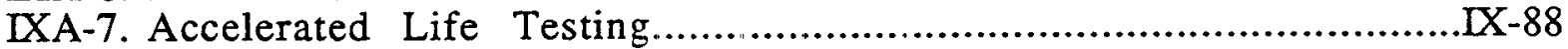

X. PROGRAMS IN UNIVERSITIES AND NATIONAL LABORATORIES ON TEACHING AND TRAINING IN SUPPORT OF A SIGNIFICANT FCSYSTEM COMMERCIALIZATION EFFORT $\ldots \ldots \ldots \ldots \ldots \ldots \ldots \ldots \ldots \ldots . . . . . .1$

$\mathrm{X}-1$. University Programs in Support of Commercialization ..........................

$\mathrm{X}-2$. The Role of the National Laboratories in the U.S. Fuel-Cell Commercialization Program ...............................................

$\mathrm{X}-3$. Summary Remarks on the Roles of Institutions......................................... 6

$\mathrm{X}-4$. Establishment of a University-Based Engineering Research Center in FCSystem Technology .................................................................

XI. FUEL-CELL PRODUCTION LEVELS AND ASSOCIATED EXTERNAL SUBSIDIES TO MANUFACTURE COST-COMPETITIVE FC SYSTEMS ...XI-1

XI-1. Critique from a Manufacturer's Perspective of Any Simplified Model to Describe Cost vs Production-Level Correlations...................................XI-2

XI-2. The "Top Down" Perspective ...............................................

XI-3. Sharing the Risks in FC-System Market Entries Between (i) FC-System Manufacturers, (ii) FC-System Purchasers and (iii) Interested Third Parties.....XI-7

XI-4. Public Benefits Anticipated Through FC-System Commercialization ............XI-7

XI-5. Summary Statements on the Status of FC-Systems (cf. Table 1-1, p. I-3).......XI-8

XI-6. Cost vs Production-Level Estimates for Hypothetical FC-Systems ...............XI-9 


\section{PREFACE:}

Formation of the Advanced Fuel-Cell Commercialization Working Group (AFC2WG) by the

OFFICE OF PROGRAM ANALYSIS of the U.S. DEPARTMENT OF ENERGY and the

\section{CHARGE TO THE WORKING GROUP}

Nearly 10 years have elapsed since this Office tasked the Advanced Fuel-Cell Working Group (AFCWG) to define research needs for advanced fuel cells that would pave the road in carrying fuel-cell technologies from the laboratory to the market place. The AFCWG report was first issued in 1985 as a Department of Energy/Office of Program Analysis report and was subsequently published in an archival journal and also as a book.* This visibility of the output of our study contributed greatly to a rapidly developing international effort to create the highly efficient, environmentally benign, sustainable technology development that is expected to result from large-scale application of fuel-cell systems wherever power conversion is needed, using either primary fossil- or renewable-energy sources.

Significant progress has been made worldwide during the last decade, no doubt reflecting the unique promise of a new technology that will not only contribute to energy efficiency and offer a very wide range of environmental benefits, but will also create high-technology jobs and singular opportunities for entering commercial markets in both developed and developing regions of the world. Nevertheless, the rate of fuel-cell market penetration has not met the expectations which we had a decade ago. This Office therefore charged the Principal Investigator of the earlier AFCWG to form an Advanced Fuel-Cell Commercialization Working Group for the purpose of providing an independent assessment of obstacles to fuel-cell technology commercialization for stationary electricity production and needed measures to facilitate commercialization.

Within the broad goal of identifying measures to proceed efficaciously to commercial sales of fuel-cell systems for stationary electricity production, the newly constituted AFC2WG was asked to emphasize each of the following important topics:

1. The present technical status of the fuel-cell technologies, including a detailed product-improvement agenda for the benefit of participating fuel-cell-stack manufacturers and potential fuel-cell-system users.

2. Description of technical, financial and regulatory obstacles and identification of measures that will facilitate market sales in competition with other advanced powerconversion technologies during the twenty-first century.

3. The technical and commercialization status of the international agenda to bring to the market an exceptionally valuable set of technologies for sustainable development.

4. Identification of needed steps and measures to assure a balanced competitive status for U.S. domestic fuel-cell developers.

\footnotetext{
* Energy - The International Journal 11, 1-230 (1986).
} 
The undersigned and many other government employees have been active participants as Ex Officio Members of the AFC2WG at the numerous discussions, presentations, conferences, technical and scientific meetings, and site visits to manufacturing facilities which formed a part of the AFC2WG programs during the last 15 months. This report constitutes the output of these activities. I take pleasure in thanking the Principal Investigator, all of the participants and especially the authors of this report (who are identified in the Appendix to the following Executive Summary) for their dedicated effort in responding to our charge.

F. Don Freeburn

Office of Program Analysis

Office of Energy Research

U.S. Department of Energy 


\section{GLOSSARY OF SYMBOLS AND ABBREVIATIONS}

\begin{tabular}{|c|c|}
\hline A & ampere \\
\hline A\&E & architects and engineers \\
\hline $\mathrm{ABB}$ & Asea Brown Boveri \\
\hline $\mathrm{AC}$ & altemating current \\
\hline $\mathrm{ACCT}$ & Alliance (Association) to Commercialize Carbonate Technology \\
\hline $\mathrm{AE}$ & air electrode \\
\hline AES & air electrode support \\
\hline $\mathrm{AFC}$ & alkaline fuel cell \\
\hline AFCWG & Advanced Fuel Cell Working Group \\
\hline AFC2WG & Advanced Fuel-Cell Commercialization Working Group \\
\hline AISI & American Iron and Steel Institute \\
\hline AIST & Agency of Industrial Science and Technology \\
\hline ANL & Argonnne National Laboratory \\
\hline APPA & American Public Power Association \\
\hline ARPA & Advanced Research Project Agency \\
\hline ASF & amperes per square foot \\
\hline atm & atmosphere \\
\hline atma & absolute atmosphere \\
\hline ATP & advanced technology program \\
\hline BAAQMD & Bay Area Air Quality Management District \\
\hline B\&W & Babcock \& Wilcox Company \\
\hline $\mathrm{BCN}$ & Brandstofcel Nederland B.V. (Dutch Fuel-Cell Corporation) \\
\hline BEST & battery energy storage test \\
\hline BMW & Bayerische Motor Werke (Bavarian Motor Works) \\
\hline BOP & balance of plant \\
\hline Btu, Btut & British thermal unit \\
\hline C & Celsius \\
\hline cal & calorie \\
\hline CAL Trans & California Transportation Department (CALTRANS) \\
\hline CCGT & combined-cycle gas turbine \\
\hline $\mathrm{CE}$ & Combustion Engineering (an ABB Company) \\
\hline CEC & Commission of the European Community \\
\hline CHP & combined heat and power \\
\hline COE & cost of electricity \\
\hline COGENT & coal gas energy transformation \\
\hline $\mathrm{cm}$ & centimeter \\
\hline $\mathrm{cm}^{2}$ & square centimeter \\
\hline CRADA & cooperative research and development agreement \\
\hline CSW & calcia-stabilized tungsten \\
\hline CSZ & calcia-stabilized zirconia \\
\hline CTE & coefficient of thermal expansion \\
\hline
\end{tabular}




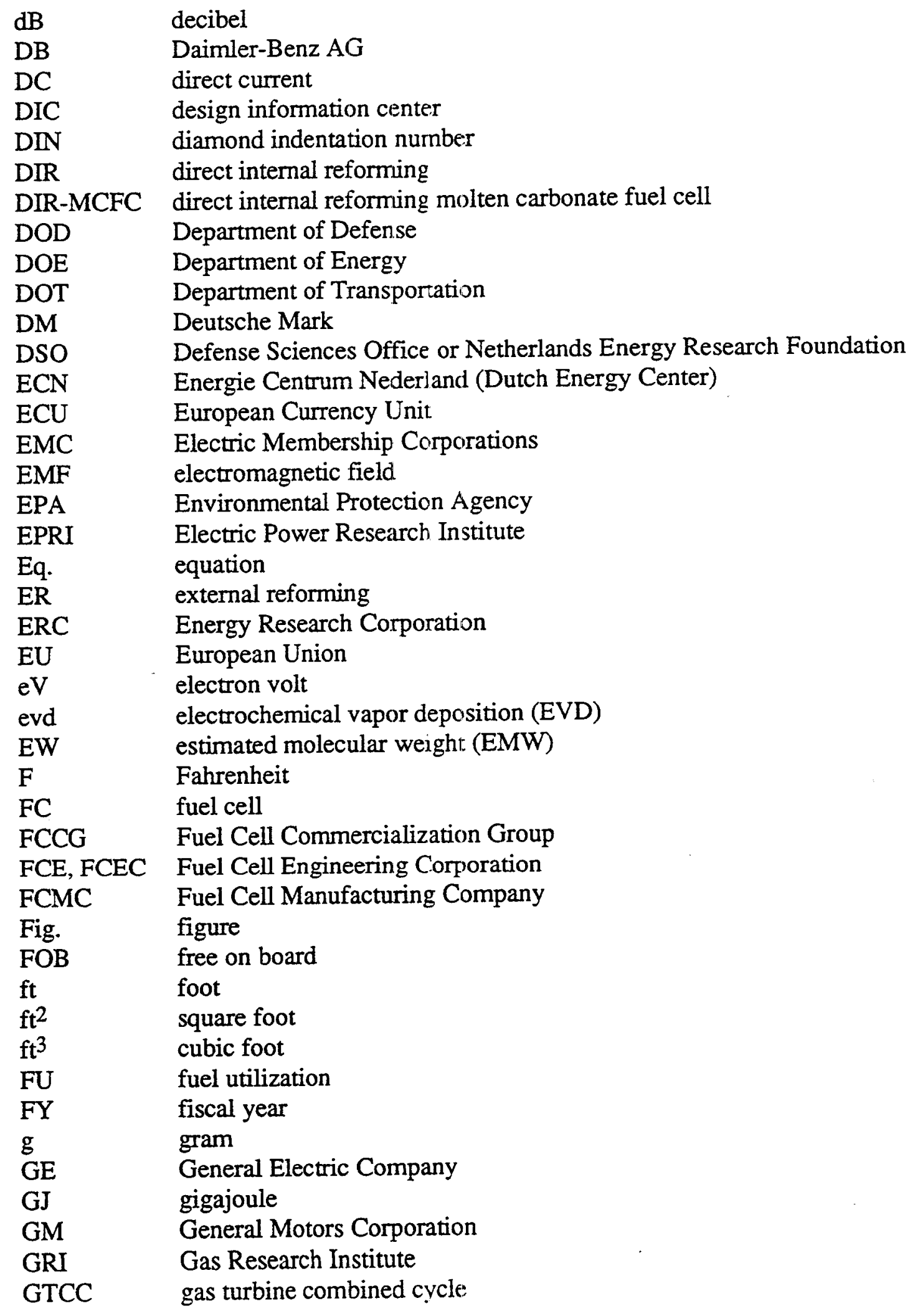




$\begin{array}{ll}\text { GW } & \text { electrical gigawatt } \\ \text { GW } & \text { thermal gigawatt } \\ \text { h } & \text { hour } \\ \text { HC } & \text { hydrocarbon } \\ \text { HHV } & \text { higher heating value } \\ \text { hp } & \text { horse power } \\ \text { HRSG } & \text { heat recovery and steam generation } \\ \text { HTFC } & \text { high-temperature fuel cell } \\ \text { Hz } & \text { hertz } \\ \text { IC-engine } & \text { internal-combustion engine (ICE) } \\ \text { IEA } & \text { International Energy Agency } \\ \text { IEEE } & \text { Institute of Electrical and Electronics Engineers } \\ \text { IFC } & \text { International Fuel Cell Corporation } \\ \text { IGCC } & \text { integrated-gasifier combined cycle } \\ \text { IGFC } & \text { integrated-gasification fuel cell } \\ \text { IGT } & \text { Institute of Gas Technology } \\ \text { IHI } & \text { Ishikawajima-Harima Heavy Industries } \\ \text { IR } & \text { indirect internal reforming } \\ \text { in } & \text { inch } \\ \text { IPP } & \text { independent power producer } \\ \text { IR drop } & \text { current } \times \text { resistance (ohmic resistance voltage drop) } \\ \text { IRMCFC } & \text { internal reforming molten carbonate fuel cell } \\ \text { JPL } & \text { Jet Propulsion Laboratory } \\ \text { Kepco } & \text { Kansai Electric Power Company (KEPCO) } \\ \text { kg } & \text { kilogram } \\ \text { kJ } & \text { kilojoule } \\ \text { km } & \text { kilometer } \\ \text { KTI } & \text { Kinetics Technology, Inc. } \\ \text { kW } & \text { electrical kilowatt } \\ \text { kWh } & \text { electrical kilowatt-hour } \\ \text { kWt } & \text { thermal kilowatt } \\ \text { kW } \text { h } & \text { thermal kilowatt-hour } \\ \text { l } & \text { liter } \\ \text { LACMTA } & \text { Los Angeles County Metropolitan Transportation Authority } \\ \text { LADWP } & \text { Los Angeles Department of Water and Power } \\ \text { LANL } & \text { Los Alamos National Laboratory } \\ \text { lb } & \text { pound } \\ \text { LBL } & \text { Lawrence Berkeley Laboratory } \\ \text { LCC } & \text { calcium-doped lanthanum chromite } \\ \text { LHV } & \text { lower heating value } \\ \text { LNG } & \text { liquefied natural gas } \\ \text { LMC } & \text { magnesium-doped lanthanum chromite } \\ \text { LSC } & \text { strontium-doped lanthanum chromite } \\ & \end{array}$




\begin{tabular}{|c|c|}
\hline $\mathrm{m}$ & meter \\
\hline M & mole \\
\hline $\mathrm{mA}$ & milliampere \\
\hline Mcal & megacalorie \\
\hline MCFC & molten carbonate fuel cell \\
\hline $\mathrm{MCP}$ & M-C Power Corporation \\
\hline Melco & Mitsubishi Electric Company \\
\hline METC & Morgantown Energy Technology Center \\
\hline $\mathrm{mg}$ & milligram \\
\hline MHI & Mitsubishi Heavy Industries Corporation \\
\hline MITI & Ministry of Intermational Trade and Industry (Japan) \\
\hline $\mathrm{mm}$ & millimeter \\
\hline MMBtu & million British thermal units \\
\hline $\mathrm{MPa}$ & megapascal \\
\hline M.S. & Master of Science \\
\hline $\mathrm{mt}$ & metric ton \\
\hline $\mathrm{mV}$ & millivolt \\
\hline MW & electrical megawatt \\
\hline MWh & electrical megawatt-hour \\
\hline $\mathrm{MW}_{\mathrm{t}}$ & thermal megawatt \\
\hline $\mathrm{MW}_{\mathrm{t}} \mathrm{h}$ & thermal megawatt-hour \\
\hline NASA & National Aeronautics and Space Administration \\
\hline Nasdaq & National Association of Security Dealers Automated Quotations \\
\hline NEDO & New Energy and Technology Agency (Japan) \\
\hline NFCRC & National Fuel Cell Research Center \\
\hline NG & natural gas \\
\hline $\mathrm{NIH}$ & National Institutes of Health \\
\hline NIST & National Institute of Science and Technology \\
\hline NL & national laboratory \\
\hline NOMO & notice of market opportunity \\
\hline NOVEM & $\begin{array}{l}\text { Nederlandse Organisatie voor Energie en Milieu (Netherlands Energy } \\
\text { and Environment Organization) }\end{array}$ \\
\hline $\mathrm{NO}_{\mathrm{x}}$ & nitrogen oxides \\
\hline NSF & National Science Foundation \\
\hline O\&M & operation and maintenance \\
\hline OECD & Organization for Economic Cooperation and Development \\
\hline OPC & Oglethorpe Power Corporation \\
\hline OPEC & Organization of Petroleum Exporting Countries \\
\hline OU & oxidant utilization \\
\hline $\mathrm{Pa}$ & pascal \\
\hline PA & phosphoric acid \\
\hline PAC & process and control \\
\hline PAFC & phosphoric acid fuel cell \\
\hline
\end{tabular}




$\begin{array}{ll}\text { PEM } & \text { proton-exchange membrane } \\ \text { PEMFC } & \text { proton-exchange membrane fuel cell } \\ \text { Pf } & \text { Pfennig } \\ \text { PFD } & \text { process-flow diagram } \\ \text { PG\&E } & \text { Pacific Gas and Electric Company } \\ \text { Ph.D. } & \text { Doctor of Philosophy } \\ \text { PI } & \text { principal investigator } \\ \text { ppm } & \text { parts per million } \\ \text { ppmv } & \text { parts per million by volume } \\ \text { PNL } & \text { Pacific Northwest Laboratories } \\ \text { PPP } & \text { purchasing power parity } \\ \text { PSE\&G } & \text { Public Service Electricity and Gas Company } \\ \text { psia } & \text { pound per square inch absolute } \\ \text { PVDIC } & \text { Photovoltaic Design Information Center } \\ \text { q } & \text { quad =1015 Btu } \\ \text { R\&D } & \text { research and development } \\ \text { RD\&D } & \text { research, development and demonstration } \\ \text { RFP } & \text { request for proposal } \\ \text { ROG } & \text { reactive organic gases } \\ \text { SCAQMD } & \text { South Coast Air Quality Management District (Los Angeles) } \\ \text { SCE } & \text { Southern California Edison Company } \\ \text { SCF } & \text { standard cubic foot } \\ \text { SCF NG } & \text { standard cubic foot of natural gas } \\ \text { SCG } & \text { Southern California Gas Company } \\ \text { SDG\&E } & \text { San Diego Gas and Electric Company } \\ \text { SMUD } & \text { Sacramento Municipal Utility District } \\ \text { SOFC } & \text { solid oxide fuel cell } \\ \text { SOX } & \text { sulfur oxides } \\ \text { SPEFC } & \text { solid polymer electrolyte fuel cell (formerly used for PEMFC) } \\ \text { SS } & \text { stainless steel } \\ \text { T\&D } & \text { transmission and distribution } \\ \text { TARGET } & \text { Team to Advance Research on Gas Energy Transformation } \\ \text { TCF } & \text { tera cubic feet = 1015 cubic feet } \\ \text { TCFNG } & \text { tera cubic feet of natural gas } \\ \text { TEPCO } & \text { Tokyo Electric Power Company } \\ \text { TGC } & \text { Tokyo Gas Company } \\ \text { TIG } & \text { tungsten inert gas } \\ \text { TMI } & \text { Technology Management, Inc. } \\ \text { TNO } & \text { Netherlands Institute for Applied Scientific Research } \\ \text { TVA } & \text { Tennessee Valley Authority } \\ \text { typ. } & \text { typically } \\ \text { UCSD } & \text { University of California, San Diego } \\ \text { UPS } & \text { uninterruptible power systems } \\ & \\ & \end{array}$




$\begin{array}{ll}\text { U.K. } & \text { United Kingdom } \\ \text { U.S. } & \text { United States of America } \\ \text { UTC } & \text { United Technologies Corporation } \\ \text { V } & \text { volt } \\ \text { W } & \text { electrical watt } \\ \text { WG } & \text { working group } \\ \text { wt } & \text { weight } \\ W_{\mathrm{t}} & \text { thermal watt } \\ \text { yr } & \text { year } \\ \text { YSZ } & \text { yttria-stabilized zirconia } \\ \Delta H & \text { enthalpy change } \\ \Delta H \mathrm{H} & \text { enthalpy of combustion } \\ \Omega & \text { ohm } \\ ¥ & \text { yen }\end{array}$




\section{ABSTRACT}

This report deals with an assessment of requirements to advance fuel-cell (FC) system manufacture, marketing and sales to the point where publicly or privately held organizations can operate profitably in the international, competitive, stationary power-equipment market of the twenty-first century. Some or all of the members of the Working Group (see Appendix IA for the membership roster) participated at seven technical meetings and discussions, site visits to facilities of U.S., Japanese and European FC-stack manufacturers and to operating FC systems in the U.S. and Japan, and assessments of the supporting RD\&D programs in the U.S., Japan and Europe performed in industrial, national and university laboratories. The Working Group also received inputs from utility executives, construction engineers, managers of federal and industry-cooperative programs, and others.

Using fossil fuels for diverse stationary and mobile power applications, FC systems may become the first important replacements in more than a century for high-temperature combustion systems because they have emissions of regulated pollutants far below currently applicable and anticipated future control levels, as well as high conversion efficiencies of fuel energy directly to electricity. Since FC systems for stationary power applications are expected to enter preferentially the on-site, distributed power market, there will be cost savings in transmission and distribution and also relief concerning the perception of health problems caused by longdistance, high-power electricity-transmission lines. FC systems may be operated with many different fuels. FC construction, installation and operation will create numerous high-technology and supporting jobs. Large markets for FCs are foreseen in many industrial sectors for both developed and less-developed countries.

The crucially important first test for FC systems of market acceptability has been passed successfully with demonstration sales of the PC25 $5^{\mathrm{TM}}$ PAFC systems manufactured by the ONSI unit of the International Fuel Cell Corporation (IFC). This report contains descriptions of developments and commercialization schedules prepared independently by the following FC manufacturers: AlliedSignal, Ballard, Ceramatec/SOFCo, Dow/Ballard, ERC, IFC, M-C Power, Westinghouse, and Ztek. The primary current issue in commercialization is increasing numbers of sales at progressively lower prices, coupled with R\&D directed at cost reduction and product improvement. Without substantial investments, there may be critical delays in large-scale construction and use of U.S. FC systems. Estimates of required funding for commercialization of the most promising FC systems are given in this report. Rapid commercialization of FC systems is in the national interest and major foreign governmental support of foreign FC commercialization efforts requires continued U.S. governmental support of U.S. manufacturers in order to maintain a level playing field in international competition.

A tabular overview of the mid-1994 status of FC developments is given in Table I-1. Examination of this table shows each of the following: (i) the greatly different status with respect to commercialization of the different types of FC systems, (ii) the urgency of large numbers of sales for all FC systems, (iii) the near-term need for successful operations of large-scale MCFCs and tubular SOFCs with complete BOPs, (iv) the proliferation of competing entries for planar SOFCS and PEMFCs, (v) both the international cooperative and 
competitive features of the developing FC technologies, and (vi) large differences in design features and application areas for the different FC-system technologies.

Potential domestic and international FC markets include (i) on-site systems on the customer or utility side of the meter with requirements from a few tens of $\mathrm{kW}$ to a few $\mathrm{MW}$, (ii) substation systems from a few to perhaps $50 \mathrm{MW}$, (iii) central station systems with outputs from 50 to hundreds of MW. For each power range, there are competing technologies at capital costs per $\mathrm{kW}$ of output well below those that can currently be met with FC systems. Nevertheless, for selected applications and regions and provided proper allowance is made for combined environmental, transmission and distribution, and quality advantages of the efficient FC systems, these systems may be used to deliver lower-cost electricity to consumers than conventional technologies. While it is generally agreed that system costs of $\$ 1500 / \mathrm{kW}$ would be attractive in assuring market penetration, there are applications and situations where the competitive price is much higher (i.e. $\$ 2500-3000 / \mathrm{kW}$ ). The potential market is so large that only a small percentage of the total is required to assure the success of a commercialization effort. The commercial entry of $\mathrm{FC}$ technologies into the market place will be negatively affected by deregulation of the utility industries.

All commercial systems require long-term basic research support for the purpose of reducing costs, improving performance, enhancing reliability, etc. R\&D for FC-system product improvement is no exception. A detailed agenda of needed R\&D leading to product improvement and cost reductions is given in this report for each of the FC systems considered in the evaluation. Because of serious budgetary constraints for supporting R\&D leading to scale-up and product improvements that are coupled to the construction of demonstration plants, the competition for $R \& D$ funds has necessarily resulted in underfunding of long-term basic research. This problem is best corrected by identifying dedicated sources of support that cannot be diverted to urgent near-term uses. 
Table I-1. Summary table on FC-commercialization status as of mid-1994; BOP means balance of plant.

\begin{tabular}{|c|c|c|c|c|c|c|c|c|}
\hline Fuel-Cell Type & \multicolumn{2}{|c|}{$\begin{array}{l}\text { Demonstration } \\
\text { Sales } \\
\text { (Power Range) }\end{array}$} & \multicolumn{2}{|c|}{$\begin{array}{l}\text { Commercial } \\
\text { Sales }\end{array}$} & \multicolumn{2}{|c|}{$\begin{array}{c}\text { Steps to } \\
\text { Commercializa- } \\
\text { tion }\end{array}$} & $\begin{array}{c}\text { Technology } \\
\text { Leader(s) } \\
\text { [Foreign } \\
\text { Associate(s)] }\end{array}$ & $\begin{array}{l}\text { Primary Foreign or US Competitors } \\
\text { [Other Important Entries] }\end{array}$ \\
\hline PAFC & \multicolumn{2}{|c|}{$\begin{array}{c}1989-91 \\
(200 \mathrm{~kW} \text { to } 11 \\
\text { MW) }\end{array}$} & \multicolumn{2}{|c|}{ Since 1992} & \multicolumn{2}{|c|}{$\begin{array}{l}\text { Large Numbers } \\
\text { of Sales }\end{array}$} & $\begin{array}{c}\text { IFC (US) [CLC } \\
\text { (Europe), } \\
\text { Toshiba } \\
\text { (Japan)] }\end{array}$ & $\begin{array}{c}\text { Fuji (Japan) [ERC (US), Melco } \\
\text { (Japan), Sanyo (Japan)] }\end{array}$ \\
\hline $\begin{array}{c}\text { Atmospheric } \\
\text { Pressure MCFC }\end{array}$ & \multicolumn{2}{|c|}{$\begin{array}{l}\text { Current } \\
(2 \mathrm{MW})\end{array}$} & \multicolumn{2}{|c|}{ Later than 1997} & \multicolumn{2}{|c|}{$\begin{array}{c}\text { Operation with } \\
\text { BOP and Large } \\
\text { Numbers of } \\
\text { Sales }\end{array}$} & $\begin{array}{c}\text { ERC (US) } \\
{[\text { Melco (Japan)] }}\end{array}$ & $\begin{array}{l}\text { IHI (Japan), [Melco (Japan), Toshiba } \\
\text { (Japan), Sanyo (Japan)] }\end{array}$ \\
\hline $\begin{array}{l}\text { Pressurized } \\
\text { MCFC }\end{array}$ & \multicolumn{2}{|c|}{$\begin{array}{l}\text { Current } \\
(250 \mathrm{~kW})\end{array}$} & \multicolumn{2}{|c|}{ Later than 1997} & \multicolumn{2}{|c|}{$\begin{array}{l}\text { Operation with } \\
\text { BOP }\end{array}$} & $\begin{array}{l}\text { MC-Power } \\
\text { (US) [IHI } \\
\text { (Japan)] }\end{array}$ & $\begin{array}{c}\text { IHI (Japan) [BCN (The Netherlands), } \\
\text { Hitachi (Japan), IFC (US), Melco } \\
\text { (Japan), MHI (Japan)] }\end{array}$ \\
\hline Tubular SOFC & \multicolumn{2}{|c|}{$\begin{array}{c}\text { Current } \\
\text { (25 kW and } \\
\text { above) }\end{array}$} & \multicolumn{2}{|c|}{ Later than 1997} & \multicolumn{2}{|c|}{$\begin{array}{c}\text { Operation of } \\
100 \mathrm{~kW} \text { and } \\
\text { larger systems } \\
\text { with BOP } \\
\end{array}$} & $\begin{array}{l}\text { Westinghouse } \\
\text { (US) }\end{array}$ & [MHI (Japan)] \\
\hline $\begin{array}{c}\text { Planar SOFC } \\
\text { (at } 20 \mathrm{~kW} \text { or } \\
\text { more) }\end{array}$ & \multicolumn{4}{|c|}{ Not determinable } & \multicolumn{2}{|c|}{$\begin{array}{l}\text { Feasibility } \\
\text { demonstration } \\
\text { for long-term, } \\
\text { thermally self- } \\
\text { sustaining } \\
\text { operation }\end{array}$} & \multicolumn{2}{|c|}{$\begin{array}{l}\text { AlliedSignal (US), Ceramatec (US), Dornier (Germany) } \\
\text { and Cookson (UK), Fuji (Japan), Fujikura (Japan), GEC } \\
\text { (UK), IGT (US), Melco (Japan), MHI (Japan), Mitsui } \\
\text { (Japan), Murata (Japan), Norcell (Norway), Osaka Gas } \\
\text { (Japan), Sanyo (Japan), Siemens (Germany) and ECN } \\
\text { (The Netherlands), Statoil (Norway), Sulzer } \\
\text { (Switzerland), Tonen (Japan), Ztek (US) }\end{array}$} \\
\hline \multirow{2}{*}{$\begin{array}{l}\text { Fuel-Cell } \\
\text { Type }\end{array}$} & \multicolumn{3}{|c|}{ Program Goals } & \multirow{2}{*}{\multicolumn{2}{|c|}{$\begin{array}{c}\text { Steps to } \\
\text { Commercial- } \\
\text { ization }\end{array}$}} & \multirow{2}{*}{$\begin{array}{l}\text { Technology } \\
\text { Leader }\end{array}$} & \multirow{3}{*}{\multicolumn{2}{|c|}{$\begin{array}{l}\text { Representative Participants: } \\
\text { AISI (Japan), AlliedSignal (US), Allison Engine Co. } \\
\text { (US), Analytic Power (US), Bestech (US), Daimler } \\
\text {-Benz (Germany), Dow (US), ElectroChem (US), } \\
\text { Eltron Research (US), Energy Partners (US), Energy } \\
\text { \& Environmental Corp. (US), ERC (US), Fuji } \\
\text { (Japan), Giner, Inc. (US), GM (US), H-Power (US), } \\
\text { ICET (US), IFC (US), Interfacial Sciences (US), } \\
\text { Lynntech (US), MHI (Japan), Physical Sciences, Inc. } \\
\text { (US), Sanyo (Japan), Siemens (Germany), Tecogen } \\
\text { (US), Westinghouse (US), plus numerous others }\end{array}$}} \\
\hline & Motive & Sta & onary & & & & & \\
\hline PEMFC & $\begin{array}{l}\text { Vehicular } \\
\text { commercial } \\
\text { applications } \\
\text { entering } \\
2005-2007 \\
\text { (according to } \\
\text { DOE) }\end{array}$ & $\begin{array}{r}\text { Sta } \\
\text { powe } \\
\text { dem } \\
\text { tion } \\
1 \text { to } \\
\text { rar } \\
\text { proj }\end{array}$ & $\begin{array}{l}\text { lonary } \\
\text { onstra- } \\
\text { in the } \\
200 \mathrm{~kW} \\
\text { ge are } \\
\text { cted by } \\
000\end{array}$ & $\begin{array}{r}\text { Feasit } \\
\text { demor } \\
\text { tion } \\
\text { accep } \\
\text { cos }\end{array}$ & $\begin{array}{l}\text { ility } \\
\text { stra- } \\
\text { at } \\
\text { able } \\
\text { ts }\end{array}$ & $\begin{array}{l}\text { Ballard } \\
\text { (Canada) }\end{array}$ & & \\
\hline
\end{tabular}




\title{
APPENDIX IA: MEMBERS AND EX OFFICIO MEMBERS OF THE DOE ADVANCED FUEL-CELL COMMERCIALIZATION WORKING GROUP (AFC2WG)
}

\author{
Chairman: S. S. Penner ${ }^{*}$ \\ UCSD \\ 9500 Gilman Drive, La Jolla, CA 92093-0310 \\ (619) 534-4284, FAX: (619) 534-5354 \\ e-mail: spenner@ames.ucsd.edu
}

\section{Fuel-Cell-Industry and Research-Organization Members}

AlliedSignal Inc. Aerospace Systems \& Equipment 2525 W. 190th Street, 93140/T41 Torrance, CA 90504-6099

Ballard Power Sustems 6591 Morning Tide Huntington Beach, CA 92648

Ceramatec Inc. 2425 South 900 West

Salt Lake City, UT 84119

EPRI

3412 Hillview Ave. Palo Alto, CA 94304
Mr. John J. Kennedy§

Product General Manager, Space Systems [(310) 512-3304, FAX: (310) 512-4128]

Alternate Member: Dr. Linus B. Buss*

Chief, Space Systems Engineering [(310) 512-4525, FAX: (310) 512-2221]

Dr. Robert B. Fleming* (Sec. 5-3 only) (for PEMFC discussions only)

Phone \& FAX Number: (714) 536-2345

Dr. Ashok Khandkar*, Sr. Scientist [(801) 972-2455, FAX: (801) 972-1925]

Mr. Edward A. Gillis*

Program Manager, Fuel Cells

[(415) 855-2542, FAX: (415) 855-2954]

Dr. John B. O'Sullivan *

Manager, Fuel-Cell Commercialization [(415) 855-2292, FAX: (415) 855-2954]

\footnotetext{
* Working Group members identified by an asterisk $\left({ }^{*}\right)$ are the authors of this report and contributed original drafts of one or more important sections. Working Group members identified by $\S$ were occasional participants at one or two AFC2WG meetings but were not involved in the preparation of the final report. Other Working Group members not identified by either * or $\S$ offered advice and comments at meetings and on written material and attended all or many of the AFC2WG meetings. Authors of sections relating to propriety information are identified with the sections they wrote.
} 
ERC

3 Great Pasture Road

Danbury, CT 06813

GRI

8600 West Bryn Mawr Ave. Chicago, IL 60631

GM Corp.

North American Operations

$\mathrm{R}$ \& D Center

30500 Mound Road, Box 9055

Warren, MI 48090-9055

Allison Engine $\mathrm{Co}$

P. O. Box 420, S.C. S-51

Indianapolis, IN 46206-0420

(For FED-X): 2001 S. Tibbs

IFC Corporation

195 Governors Highway

P.O. Box 739

South Windsor, CT 06074

IGT

$\frac{1700}{170}$ South Mount Prospect Road

Des Plaines, IL 60018-1804

\section{M-C Power}

8040 South Madison St., Burr Ridge, IL 60521-5808
Dr Bernard S. Baker*, President

[(203) 792-1460, FAX: (203) 798-2945]

Alternate Member:

Dr Hans Maru§, Executive Vice President [(203) 792-1460, FAX: (203) 798-2945]

Dr Kevin Krist (to 07/01/94)

Senior Project Manager, Inorganic Chemistry [(312) 399-8211]

Mr. James A. Kimball§ (from 07/01/94)

Principal Technology Manager

Energy Conversion

[(312) 399-8178, FAX: (312) 399-8170]

Dr. Swathy Swathirajan $\S$

(for PEMFC discussions only) Section Manager Physical Chemistry Dept.

[(313) 986-0702, FAX: (313) 986-2244]

Dr. Howard F. Creveling§

(for PEMFC discussions only)

Program Manager, Allison Corp.

[(317) 230-4469, FAX: (317) 230-4078]

Mr. Paul J. Farris*

[(203) 727-2305, FAX: (203) 727-2319]

Alternate Member: Mr. Sigurd H. Folstad $\$$

Vice President,

Technology and Business Development

[(203) 727-2306, (FAX): (203) 727-2399]

Dr. L.G. Marianowski, Director

Energy Conversion and Storage Research

[(708) 768-0500, FAX: (708) 768-0501]

Mr. Paul Tarman*, President

[(708) 986-8040 (EXT 100), FAX: (708) 986-

8086]

Alternate Member: Mr. Lee Camara

[(708) 986-8040 (EXT 151)] 
The Dow Chemical Company 2030 Dow Center

Midland, MI 48674

Westinghouse Electric Corp. Science \& Technology Center 1310 Beulah Road

Pittsburgh, PA 15235-5098

Ztek Corporation 460 Totten Pond Road Waltham, Massachusetts 02154
Dr. Jeffrey A. Gunsher", Project Manager Ventures Department [(517) 636-0411, FAX: (517) 636-8127]

Dr. Walter J. Dollard*, General Manager Advanced Energy Conversion Division [(412) 256-5300, FAX: (412) 256-2002]

Dr. Michael Hsu* (Sec. V-10 only) President (617) 890-5665, FAX: (617) 890-3731

\section{Industry Advisory Members on Commercialization}

Stone \& Webster Engineering Corp. Dr. John W. Landis

P.O. Box 2325

Boston, MA 02107

Bechtel Corporation

50 Beale Street

San Francisco, CA 94119-3965

General Public Utilities Service

Corporation

100 Interpace Parkway

Parsippany, N.J. 07054
Senior Executive Consultant

[(617) 589-1611, FAX: (617) 589-2156]

Member: Dr. Lawrence T. Papay§

Senior Vice President

[(415) 768-0275, FAX: (415) 768-0503]

Alternate Member: Dr. Tan-Ping Chen Manager of Coal Conversion

[(415) 768-1419, FAX: (415) 768-3580]

Member: Mr. Marvin Raber $\$$

Vice President of Strategic Planning

[(201) 263-6266, (FAX): (201) 263-6397]

Alternate Member: Mr. Gerry Runte*

Business Development Director

[(201) 263-6500]

\section{University-Based Members}

Dr. A. John Appleby ${ }^{*}$, Director, Center for Electrochemical Systems, The Texas A \& M University System, College Station, TX 77843-3402, [(409) 845-8281, FAX: (409) 8459287]

Dr. J. Robert Selman*, Dept. of Chemical Engineering, Armour College of Engineering, IIT Center, Chicago, IL 60616, [(312) 567-3065, 3037 or 3040, FAX: (312) 567-6914 or 8874, email: cheselman@iitvax.iit.edu] 
Dr. David A. Shores*, Dept. of Chemical Engineering and Materials Science, 151 Amundson Hall, University of Minnesota, 421 Washington Ave., Minneapolis, MN 55455, [(612) 625-0014, FAX: (612) 626-7246]

Dr. Robert F. Savinell*, Director, Case Center for Electrochemical Sciences, Case Western Reserve University, 10900 Euclid Ave., Cleveland, Ohio 44106-7217, [(216) 368-2728, FAX: (216) 368-3016]

Dr. Jan Talbot, Dept. of Chemical Engineering, UCSD, 9500 Gilman Drive, La Jolla, CA 92093-0310, [(619) 534-3176, FAX: (619) 534-4543]

\section{Ex Officio Members}

Mr. F. Don Freeburn and Mr. Robert Rosenthal

Research and Technical Assessment Division (ST-112)

Office of Program Analysis

Office of Science and Technology

Advisors U.S. Department of Energy

Washington, D.C. 20585

[(301) 903-3156, FAX: (301) 903-556i,

e-mail: don.freeburn\%er@mailgw.er.doe.gov and

rob.rosenthal\%er@mailgw.er.doe.gov]

Mr. Steven G. Chalk

U.S. Department of Energy

Office of Energy Efficiency and Renewable Energy, EE-321

Office of Transportation Technologies

Washington, D.C. 20585

(202) 586-3388

Dr. Lawrence H. Dubois

Advanced Research Projects Agency/

Defense Sciences Office (ARPA/DSO)

3701 No. Fairfax Drive

Arlington, Virginia 22203-1714

[(703) 696-2283, FAX: (703) 696-2201]

email: ldubois@arpa.mil

Mr. Manville J. Mayfield*†

Product Manager, Fuel Cells

U.S. Department of Energy

Morgantown Energy Technology Center

P.O. Box 880

3610 Collins Ferry Road

Morgantown, West Virginia 26507-0880

(304) 291-4847, FAX: (304) 291-4403

† Deceased September 8, 1994. 
Dr. Pandit G. Patil

U.S. Department of Energy

Office of Energy Efficiency and Renewable Energy, EE-321

Office of Transportation Technologies

Washington, D.C. 20585

(202) $586-8055$

Mr. Charles E. Pax

U.S. Department of Energy

Office of Fossil Energy, FE-73

Washington, D.C. 20585

(301) 903-2832

\section{National Laboratory Representatives}

Dr. J. Lambert Bates*

Materials Sciences, MSNN K2-45

Pacific Northwest Laboratory

Battelle Blvd.

P.O. Box 999

Richland, WA 99352

[(509) 375-2579, FAX: (509) 375-2186]

Dr. Elton J. Cairns, Director

Energy \& Environment Division

Bldg. 90, Rm. 3030

Lawrence Berkeley Lab., University of California

Berkeley, CA 94720

[(510) 486-5028, FAX: (510) 486-5454, email: ejcairns@lbl.gov]

Dr. Ross A. Lemons (for PEMFCs only)

MS D429 Los Alamos National Laboratory

Los Alamos, NM 87545

[(505)667-6832,FAX: (505)665-4292, email: lemons@meediv.lanl.gov]

Dr. Michael Krumpelt*

Chemical Technology Division

Argonne National Laboratory

Argonne, IL 60439

[(708) 252-8520, FAX: (708) 252-4176] 


\section{IN MEMORIAM}

Our Colleague, Manville J. Mayfield, died in a tragic airplane accident on September 8. He was for many years a dominant and guiding figure of fuel-cell development and commercialization in the U.S. and the World, a tireless and incisive contributor at our many meetings, and a valued friend. We shall miss him. The international agenda for fuel-cell commercialization has lost an irreplaceable champion. 



\section{STATUS AND DEVELOPMENT OF FC SYSTEMS}

\section{II-1. Introduction}

All FCs operate on hydrogen fuel. But hydrogen is neither readily available in the quantities needed for widespread use as a fuel nor at prices competitive with fossil fuels. Therefore, hydrogen-fueled FC systems have been developed only for specialty applications such as manned spacecraft and submarine propulsion. Most FC systems intended for commercial use have been or are being developed to use readily available fuels, primarily natural gas with lesser emphasis on petroleum, alcohols and coal. The FC power plants contain subsystems that convert the primary fuel to a hydrogen-rich gas stream that is in turn provided to the FC stack. The different types of FCs have different tolerances to other components of this gas stream. Hence, the nature of this fuelprocessing subsystem is necessarily different for different FCs. A summary of fuel requirements and other characteristics of different types of FCs that bear on integration of the FC with the remainder of the power-plant system is given in Table II-1.1.

The most common fuel-conversion process used in all FC systems for all fuels except coal is catalytic steam reforming. ${ }^{1}$ In this process, the fuel plus steam are passed through a heated catalyst bed (the catalyst is typically nickel supported on a porous ceramic pellet or ring) at $1300-1600 \mathrm{~F}$. The hydrocarbon fuel reacts with steam to yield $\mathrm{H}_{2}$ and $\mathrm{CO}$ with the formation of small amounts of $\mathrm{CO}_{2}$ and $\mathrm{CH}_{4}$ plus residual steam and other components such as sulfur and chlorine compounds and ammonia derived from fuel contaminants. Autothermal reforming and partial oxidation processes are also being considered, ${ }^{2}$ with the latter process capable of utilizing coal. These processes provide

${ }^{1}$ J.R. Rostrup-Nielsen, Catalytic Steam Reforming, Springer Verlag, Berlin (1984).

2EPRI EM-50-570, "Assessment of Fuel Processing Alternatives for Fuel Cell Power Generation," Catalytica Associates, Palo Alto, CA (September 1977). 
somewhat similar gas compositions to reforming if oxygen is used in the reaction; if air is used, then the product stream will contain a significant quantity of nitrogen and some nitrogen-containing compounds.

Catalytic steam reformers have been in use in refineries and ammonia-synthesis (for fertilizer production) plants for many decades. Reformers designed for the chemical process industry are not well suited for FC power-plant applications, however. They are much too large since they typically have equivalent hydrogen-production capacities of $100 \mathrm{MW}$ or more and are constructed for steady-state, year-round operation. Power-plant operators desire intermittent and variable throughput operations with rapid start and stop cycles, unattended operation and truck-transportable modular construction. These features required significant engineering changes to the reformer technology, and it is only in recent years that the chemical process industry has begun providing reformers specifically designed for FC applications. Prior to this market introduction, the FC developer had no choice but to design and develop the reformer in-house.

Integration of the FC with the fuel processor has a major influence on power-plant performance, operability and cost. It can be argued, in fact, that it was delays in completing the engineering development of the integrated system that have held back the commercial introduction of PAFC systems. The developers of other types of FC systems have yet to complete this engineering-development phase, which may again become the pacing activity in successful market entry.

In the following sections, design considerations for various systems and the status of their development towards market entry will be described. 
Table II-1.1. Current FC-stack characterissics and fuel requirements.

\begin{tabular}{|c|c|c|c|c|}
\hline & \multicolumn{4}{|c|}{ Fuel-Cell Type } \\
\hline Parameters & PEM & PAFC & MCFC & SOFC (Tubular) \\
\hline $\begin{array}{l}\text { Operating } \\
\text { temperature, F }\end{array}$ & $<210$ & $\sim 400$ & $\sim 1250$ & $\sim 1800$ \\
\hline $\begin{array}{l}\text { Operating } \\
\text { Pressure, ata. }\end{array}$ & 1 to 5 typ. & 1 to 8 & 1 to 3 typ. & 1, desired $>10$ \\
\hline $\begin{array}{l}\text { Construction } \\
\text { Material }\end{array}$ & $\begin{array}{l}\text { Graphitic } \\
\text { Carbo's }\end{array}$ & $\begin{array}{l}\text { Craphitic } \\
\text { Carbon }\end{array}$ & Ni \& St. Steel & $\begin{array}{l}\text { Ceramics } \\
\text { and Metals }\end{array}$ \\
\hline $\begin{array}{c}\text { Power Density } \\
\text { pounds } / \mathrm{kW} \\
\mathrm{kg} / \mathrm{kW} \\
\mathrm{ft}^{3} / \mathrm{kW} \\
\text { liters } / \mathrm{kW} \\
\end{array}$ & $\begin{array}{c}\text { DOE Gcals } \\
8-10 \\
4-5 \\
\sim 0.2 \\
3-5 \\
\end{array}$ & $\begin{array}{l}\sim 25 \\
0.4\end{array}$ & $\begin{array}{l}\sim 60 \\
\sim 1\end{array}$ & $\begin{array}{l}\sim 40 \\
\sim 1\end{array}$ \\
\hline Heat Rejection, $\mathrm{kWt} / \mathrm{kW}$ & $\sim 0.4 \varepsilon @ 0.8 \mathrm{~V}$ & $\sim 0.55 @ 0.74 \mathrm{~V}$ & $\sim 0.25 @ 0.8 \mathrm{~V}$ & $\sim 0.52 @ 0.6 \mathrm{~V}$ \\
\hline Cooling Medium & Water & Boiling Water & Excess Air & Excess Air \\
\hline Fuel Requirements & & & & \\
\hline $\mathrm{H}_{2}$ & Fuel & Fuel & Fuel & Fuel \\
\hline $\mathrm{CO}$ & Poison & Poison at $\geq 3 \%$ & Fuel & Fuel \\
\hline $\mathrm{CH}_{4}$ & Diluent & Diluent & Fuel & Fuel \\
\hline $\mathrm{NH}_{3}$ & Poison & Poison & Diluent & Fuel \\
\hline $\mathrm{Cl}_{2}$ & Poison & Poison & Poison & Poison? \\
\hline $\mathrm{S}_{2}$ & Poison & Poison & Poison & Poison \\
\hline Special Problems & $\begin{array}{c}\text { Moisture } \\
\text { control in } \\
\text { the membrane }\end{array}$ & $\begin{array}{l}\text { High-voltage } \\
\text { operation }\end{array}$ & $\begin{array}{l}\text { High fuel } \\
\text { utilization }\end{array}$ & $\begin{array}{l}\text { High fuel or } \\
\text { oxidant } \\
\text { utilization }\end{array}$ \\
\hline Reference Number in Chapter II & 5 & 3 & 9 & 8 \\
\hline
\end{tabular}




\section{II-2. Low-Temperature Systems (PAFCs and PEMFCs)}

\section{II-2.1. PAFCs}

Figure II-2.1 depicts the detailed process-flow diagram (PFD) prepared during the conceptual design phase of the 11-MW PAFC power-plant development. ${ }^{3}$ The 11-MW cogeneration power plant shown in Fig. II-2.2 was constructed for the Tokyo Electric Power Company (TEPCO) by Toshiba and IFC, the parent corporations of ONSI. The plant is presently in operation using LNG (liquefied natural gas), which is nearly pure methane fuel and has achieved the target efficiency of $41 \%$ HHV. The PAFC stacks are contained in each of the 18 cylindrical pressure vessels shown on the left side of Fig. II2.2. The fuel-processing system and other equipment to integrate it with the FCs make up the remainder of the equipment shown in the photograph of Fig. II-2.2. Not shown are the cooling towers, power-conditioning system and control room. It is apparent from the photograph that a great deal of equipment is needed for such a small capacity power station, equipment that approached 1.8 million pounds in total weight (164 pounds/ $\mathrm{kW}$ ), excluding the foundations and buildings. Inspection of the PFD shows five packed-bed reaction vessels in addition to the reformer vessel to produce fuel with the required characteristics for the PAFC and 13 heat exchangers to integrate the various subsystems thermally in order to achieve reasonable overall plant efficiency. The reformer is the single largest vessel in the power plant, being approximately 20 feet tall and weighing 61 tons. The FC stacks with pressure enclosures represent $\approx 25 \%$ of the total plant weight and $\approx 20 \%$ if the pressure-vessel weight is excluded. Expressed another way, the power plant is four to five times heavier (and a similar factor larger in area and volume) than the FC stacks alone, which is a clear indication that the non-electrochemical aspects of the

${ }^{3}$ EPRI EM-3161, "Description of a Generic 11-MW Fuel Cell Power Plan for Utility Applications," United Technologies Corporation, Windsor, CT (September 1983). 
power plant have major influences on the applications, design, operation, and cost of the technology.

The 11-MW plant is pressurized to 8 atmospheres to increase the PAFC power density and reduce the size of the balance of the system vessels, heat exchangers and interconnecting piping. The $200-\mathrm{kW} \mathrm{PC} 25 \mathrm{C}^{\mathrm{TM}}$ cogenerator recently announced ${ }^{4}$ by ONSI is an unpressurized PAFC system with an expected electrical efficiency of $36 \% \mathrm{HHV}$. It is expected to weigh 40,000 pounds, i.e. 200 pounds $/ \mathrm{kW}$. The PAFC stack is again a small fraction of the plant weight and volume. For atmospheric pressure operation, the system and controls are simplified since a motor-driven blower replaces the turbocompressors, intercooler and auxiliary burner in Fig. II-2.1. In addition, integration of functions within the fuel-processor system greatly simplifies the overall packaging and process design.

\section{II-2.2. PEMFCs}

Several PEM fuel-cell manufacturing companies are developing NG-fueled, packaged cogeneration systems, although few details of the system designs appear in the open literature. A PEMFC has more restrictive fuel-quality requirements than a PAFC; the $\mathrm{CO}$ content must be reduced to the ppm level to prevent poisoning of the FC-anode catalyst. This reduction can be accomplished by adding a selective oxidation catalyst bed and a heat exchanger to control the bed temperature. The PEMFC requires about the same quantity of excess-heat management as the PAFC but the temperature is not sufficiently high to raise steam; hence, higher cooling-water flow rates are needed, and other means must be employed to provide the steam required by the reformer. The PEMFC stack will be significantly smaller than the equivalent PAFC stack. However, the remainder of the

\footnotetext{
${ }^{4}$ Press Release, ONSI Corporation, Windsor, CT (December 1993).
} 


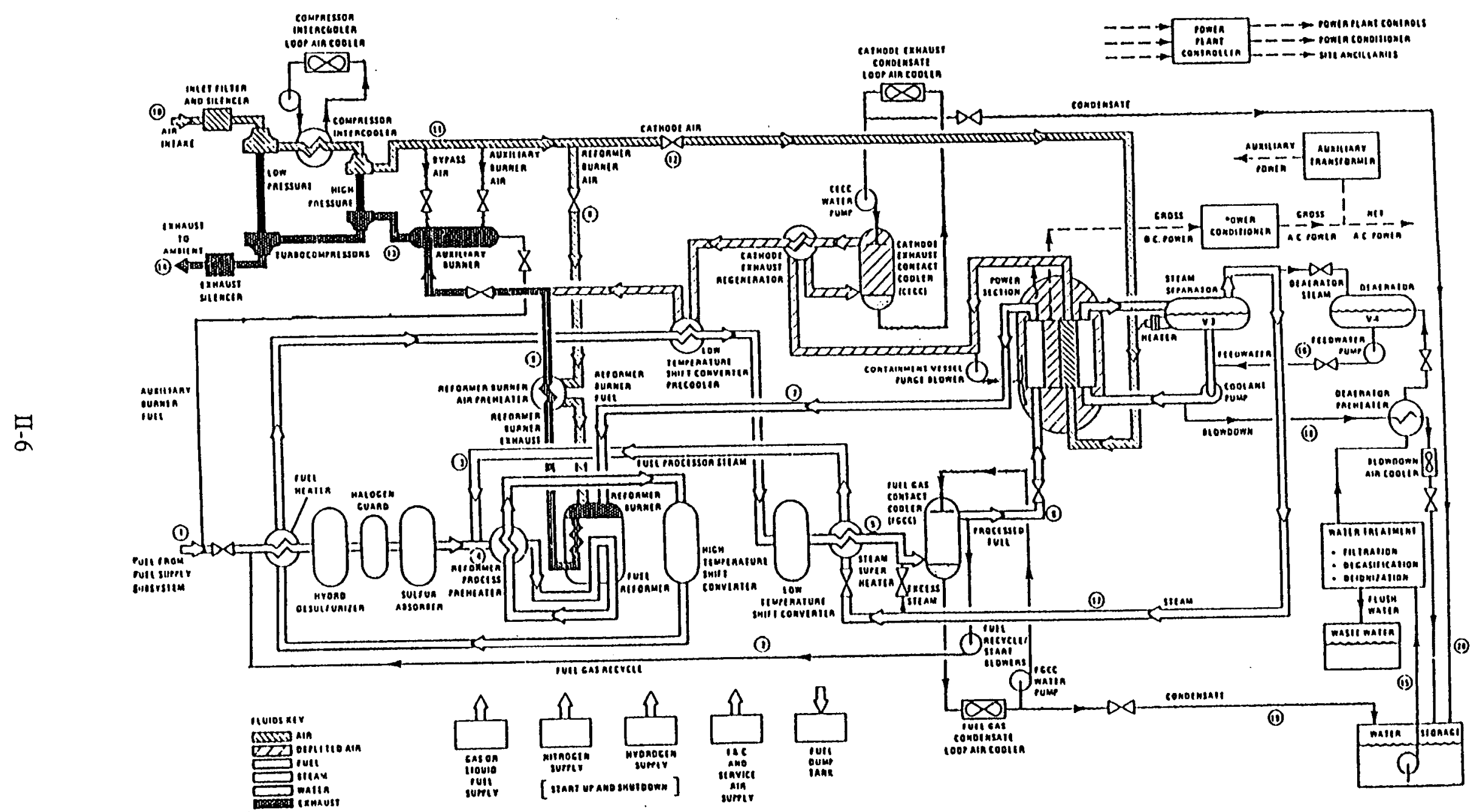

Fig. II-2.1. Power plant process-flow schematic for the11-MW PAFC operated by TEPCO. 


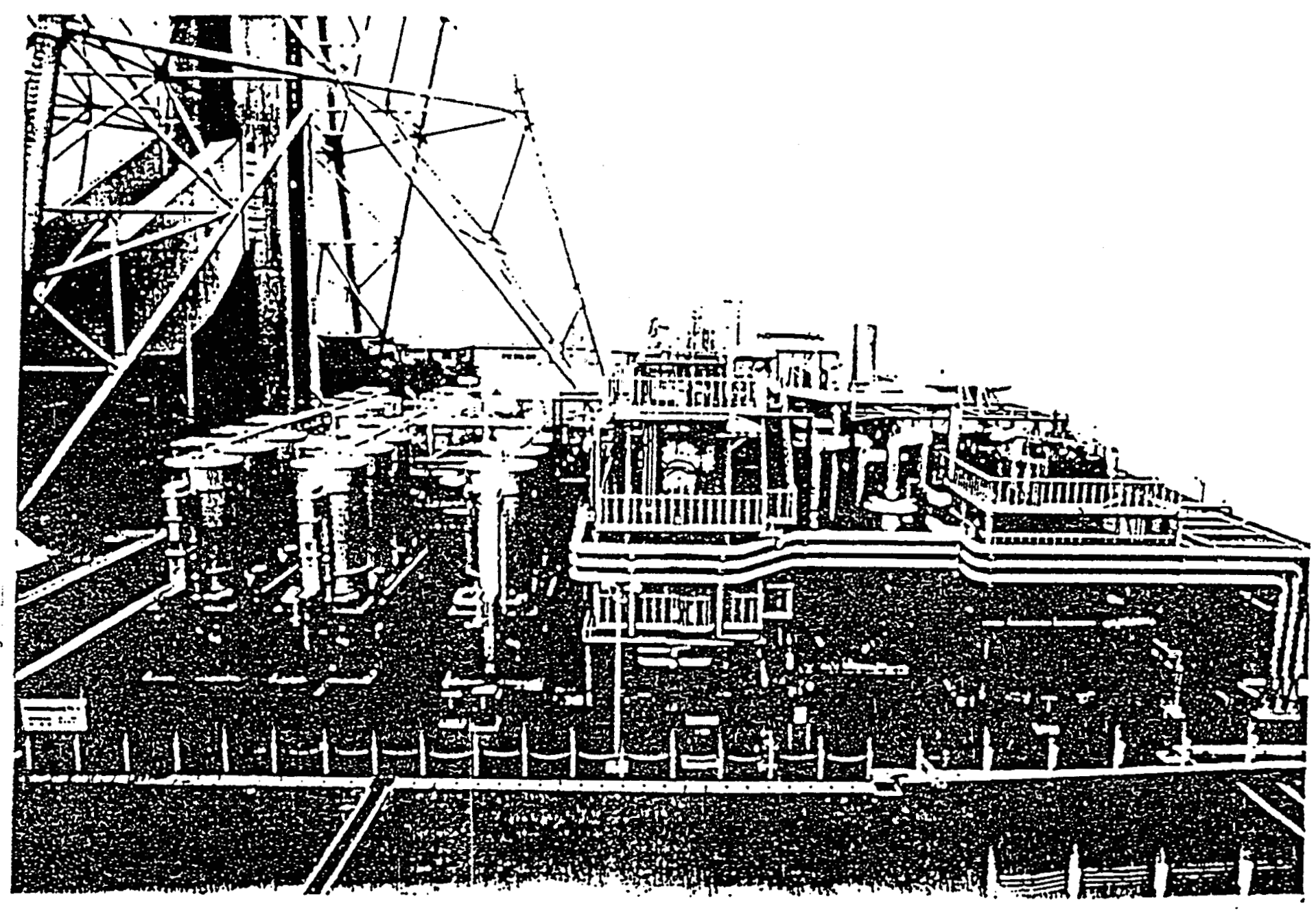

Fig. II-2.2. Photograph of the 11-MW TEPCO cogeneration plant. 
power plant will be similar to or larger in size and weight than a PAFC system. PEMFCs are expected to be comparable in performance, size and weight. If a low-cost membrane can be developed, the costs should also be comparable. The PEMFC has one clear advantage over the PAFC in its ability to tolerate 10 or more times larger differential reactant pressures in the stack, which simplifies the PEMFC system-control requirements if pressurized operations are selected.

Although commercial entry is anticipated some years later than for stationary power applications, much work is underway world-wide on PEMFCs for transportation applications using methanol or hydrogen fuel. ${ }^{5}$ PEMFC stacks are lighter in weight and more compact than other FC stacks, which is very important in mobile systems. Methanol is a much easier fuel to decompose than any petroleum product; it can be catalytically steam-reformed at temperatures as low as $400 \mathrm{~F}$. Thus, the reformer can be made to start up quickly and it can be constructed of light-weight materials, both of which are important factors for vehicle applications. Figure II-2.3 shows a conceptual design for an experimental 10-kW system being constructed under DOE sponsorship. Proof-of-concept testing in passenger vehicles is expected to begin in 1998 with initial market penetration in 2004. There are not believed to be any technical issues that prevent the construction of a light-weight and functional PEMFC-methanol system. Unfortunately, automotive applications require capital costs of $\approx \$ 150 / \mathrm{kW}$ for the FC system to be competitive with internal combustion engines, which will be a very difficult target to achieve. Cost targets for city buses, however, may be as much as five times higher due to their high utilization factors and the importance of fuel efficiency. This is clearly an important transportationentry market for PEMFC systems. Fuel-cell powered buses will probably have market

${ }^{5}$ P.G. Patil, Journal of Power Sources 37, 171-179 (September 1991). 
penetration in some areas prior to 2000; proof-of-concept testing is currently underway in the DOE methanol-fueled fuel-cell bus using PAFCs. Furthermore, PEMFC-powered buses using $\mathrm{H}_{2}$ as fuel have been tested in .North America and Europe.

\section{II-3. High-Temperature Systems (MCFCs and SOFCs)}

These FCs can use $\mathrm{CO}$ as fuel (via the water-gas shift reaction). As the result, vessels and catalyst beds for the two shift-reaction stages and the selective oxidation stage are eliminated. Operating temperatures of the high-temperature FCs and catalytic steam reformer are similar. Hence, many of the heat exchangers for the low-temperature FC-systems are also eliminated. In fact, the catalytic steam reformer can be incorporated within or placed adjacent to the FC stack so that the reject heat from the FC stack will provide some or all of the endothermic energy required by the reforming reaction.

\section{II-3.1. Two MCFC Systems}

Figure II-3.1 shows a simplified PFD for a 45\% efficient HHV, NG-fueled, 2MW MCFC system in which most of the fuel reforming takes place within the FC stack. ${ }^{6}$ The reformer R-102 processes less than $10 \%$ of the fuel to provide $\mathrm{H}_{2}$ for the desulfurization system. This atmospheric pressure system, designed by ERC, uses three heat exchangers during operation. The weight of the equipment in this plant is not given in the open literature. However, it is expected to weigh fewer pounds $/ \mathrm{kW}$ than the PAFC system, even though the FC stacks themselves are more than twice as heavy. The plant land requirement is one half that of the 11-MW PAFC plant on a $\mathrm{ft}^{2} / \mathrm{kW}$ basis and the system is no taller. ${ }^{*}$ Therefore, the volumetric power density is also proportionally better. It is doubtful that the packing density of the balance of plant equipment would be greatly

${ }^{6}$ EPRI TR-101107, "Availability of a 2-MW Carbonate Fuel Cell Power Plant," by ARINC Corporation, Palo Alto, CA (September 1992).

* This statement does not apply to the current Santa Clara MCFC design. 


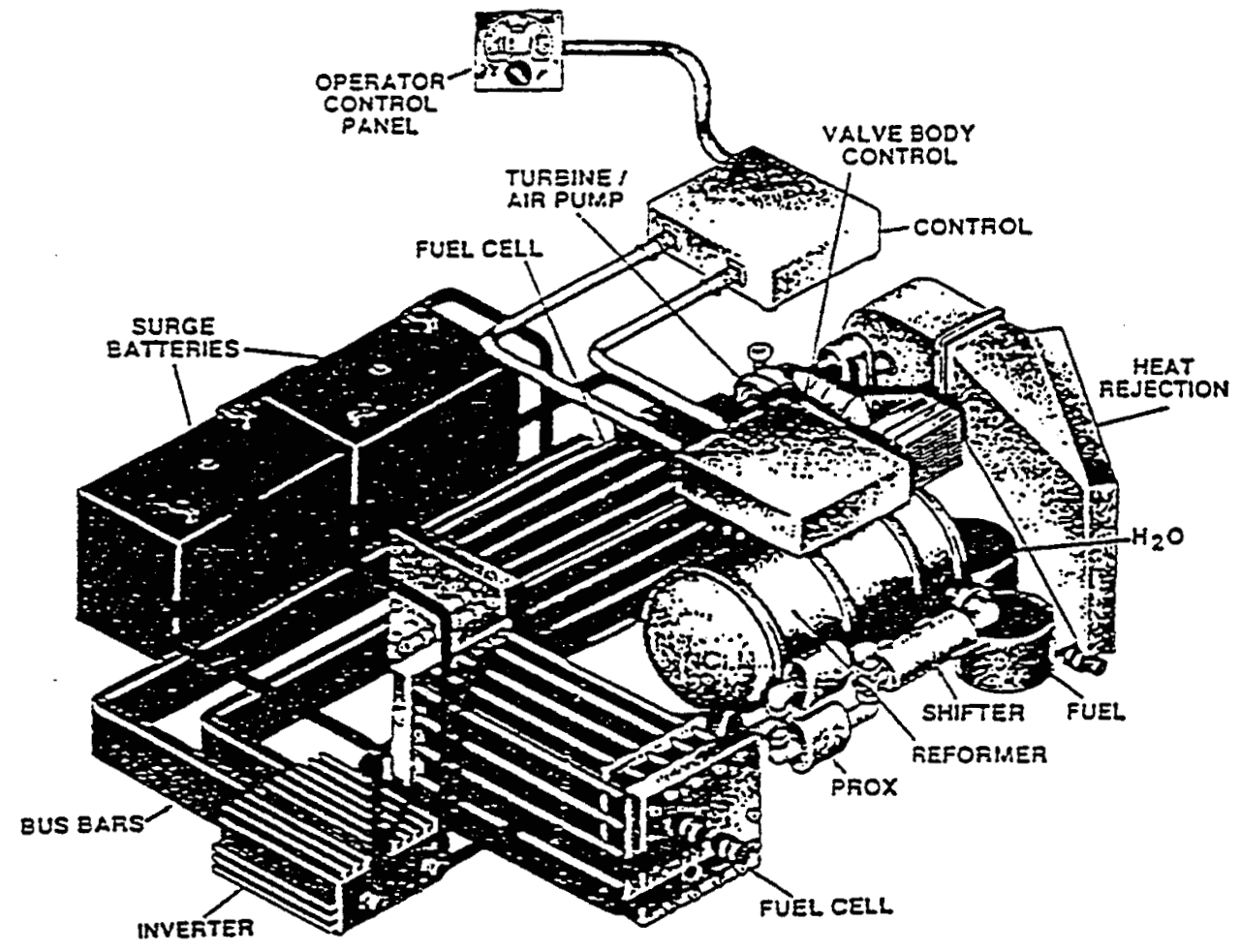

Fig. II-2.3. Conceptual design of a 10-kW PEMFC system. 
different for the two systems and, as the result, the system specific weight should be lower for the MCFC than for the PAFC system.

Figure II-3.2 shows the simplified PFD for a 1-MW pressurized MCFC cogeneration power plant designed by MCP. ${ }^{7}$ The reformer is separate from the FC stack but is contained in the same enclosure to facilitate thermal integration and minimize piping. The plant contains 4 heat exchangers with some of the heat-transfer area designated to providing $\approx 0.4 \mathrm{MW}$ thermal energy (as steam) to a customer. The total plant weight is not given. However, the specific volume is similar to that of the Westinghouse design described in Sec. I-3.2.

\section{II-3.2. A Tubular SOFC System}

Figure II-3.3 shows the simplified PFD for a 20-MW LNG-fueled SOFC designed by Westinghouse. ${ }^{8}$ This is a $51 \%$ efficient $\mathrm{HHV}$, atmospheric pressure system. It contains eight heat exchangers, five of which are utilized by the steam Rankine-cycle bottoming system. The total system weight is not published. However, the specific volume of this design is one-third smaller than that of the 2-MW MCFC and the specific weight is thus expected to be lower as well. ${ }^{9}$ To utilize pipeline NG, a hydrodesulfurizer system such as that used in the 2- or 11-MW MCFC and PAFC systems, respectively, would have to be added. This addition should not materially impact the plant design, cost or performance. In developing this design, Westinghouse chose a high-power operating point for the FC to minimize FC-stack cost and then made up stack-efficiency losses by adding the steam cycle. The plant efficiency without the steam cycle is $41 \%$ HHV. This feature is reflected by the heat-rejection rate shown in Table II-1.1 for the SOFC.

\footnotetext{
${ }^{7}$ Brochure, M-C Power Corporation, Burr Ridge, IL (March 1994).

${ }^{8}$ EPRI TR-100713, "Evaluation of Solid Oxide Fuel Cell Applications," Westinghouse Electric Corporation, Pittsburgh, PA (May 1992).

9EPRI TR-102931, "Applications of Carbonate Fuel Cells," Palo Alto, CA (September 1993).
} 


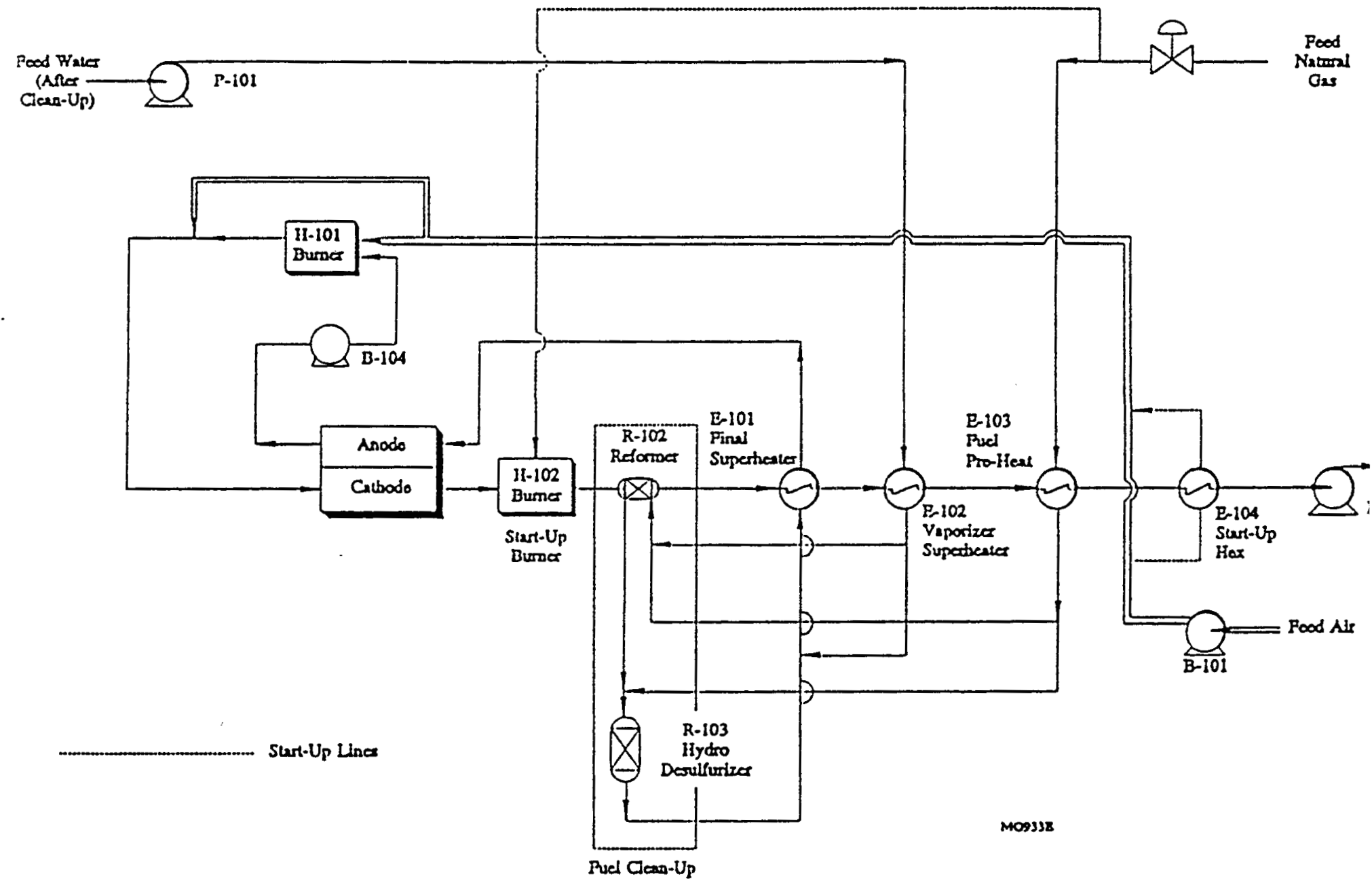

Fig. II-3.1. The ERC 2-MW FC power-plant-system flow diagram. 


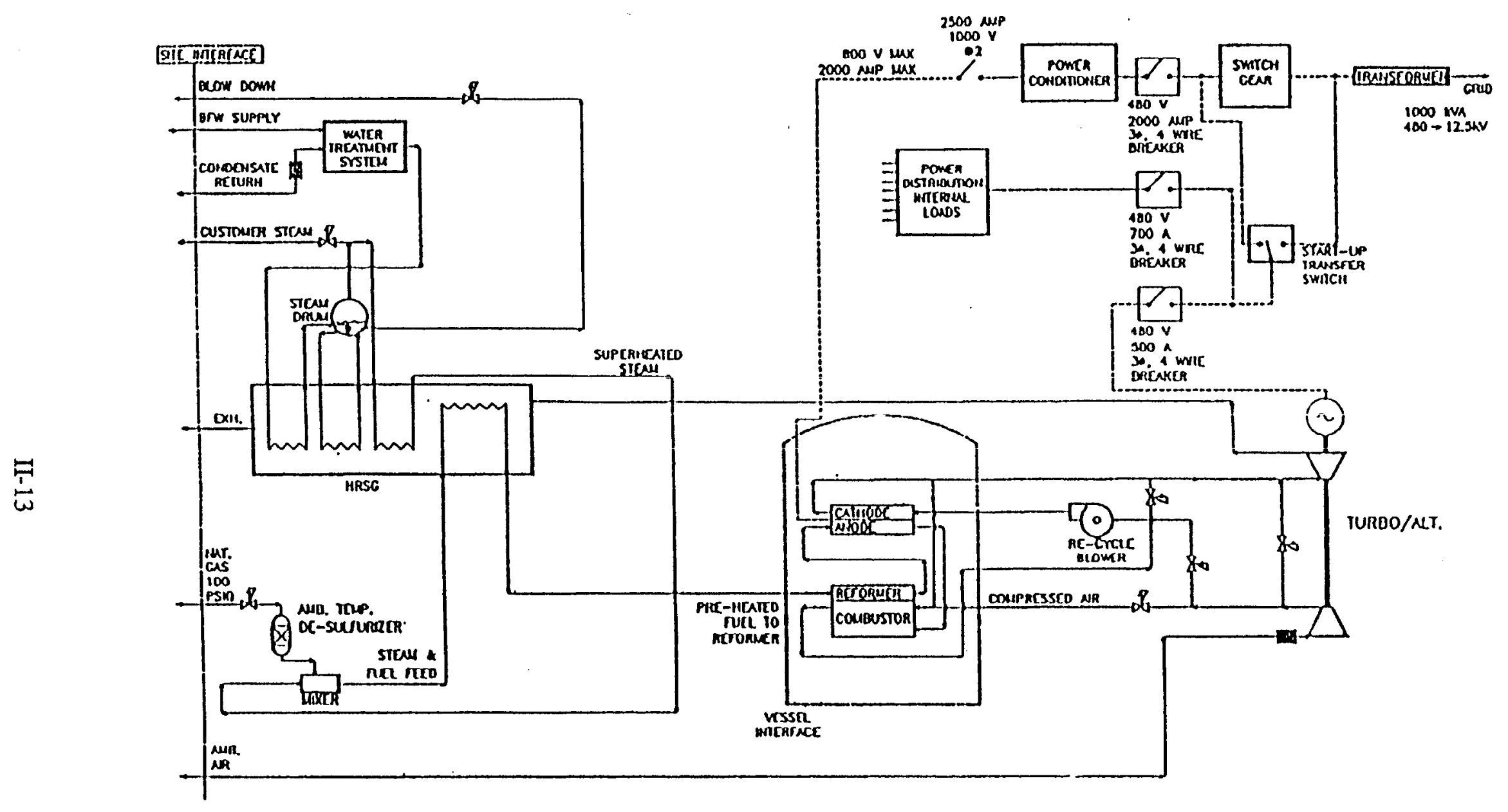

Fig. II-3.2. Schematic of the M-C Power 1-MW MCFC conceptual power-plant design. 
宫

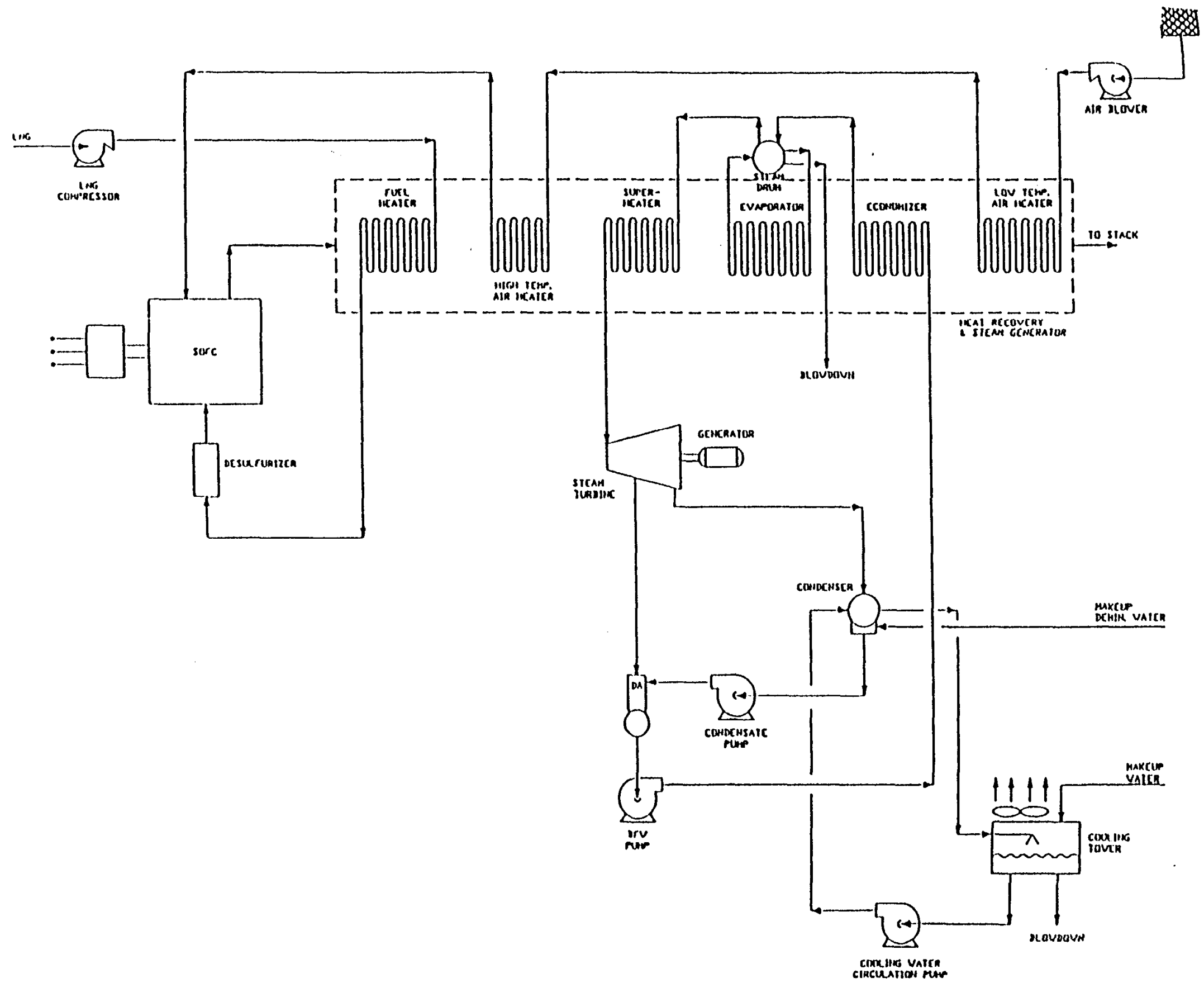

Fig. II-3.3. The 20-MW Westinghouse tubular SOFC power-plant process-flow diagram for use with $L N G$. 
For smaller capacity SOFC power plants where steam-bottoming cycles may not be economically advantageous, a lower power density and higher efficiency stack-design point could be chosen to maintain $45-50 \%$ system efficiency.

\section{II-4. Power-Conditioning Systems}

Most applications for stationary FC power plants will require alternating current electrical power output. Solid-state DC-to-AC power-conditioning systems are available commercially for all power ratings at relatively affordable prices. They are not simply plug-in units, however. The interface between the FC and the power conditioner must be understood and controls properly integrated, together with the interface between the power conditioner and the electrical grid and/or load. Although these are relatively straightforward engineering activities, they require expenditures for design and verification in power-plant demonstrations.

\section{II-5. Commercialization Implications}

Heat exchangers are reliable pieces of equipment. The number required in a system is indicative of both the control complexity (since each requires some flow control and instrumentation) and relative system capital cost. The excellent reliability demonstrated by the fleet of ONSI PC25 $5^{\mathrm{TM}}$ units in service demonstrates that complex FC systems can be engineered to have very satisfactory performance, operability and maintainability characteristics. At present, the $\mathrm{PC} 25^{\mathrm{TM}}$ remains an expensive system at $\approx \$ 3000 / \mathrm{kW}$ FOB the factory.

Use of the high-temperature systems requires very careful material selection but should be less complex with regard to heat-exchanger count, equipment weight, plant footprint, and plant volume. However, full-scale systems have not yet been built either as demonstration units or operated as procuction units. The power-plant demonstration 
phases to prove operability and reliability must be completed just as for the $\mathrm{PC} 25^{\mathrm{TM}}$. Furthermore, performance, reliability, durability, and economy under power-plant operating conditions must be verified for high-temperature FC stacks.

\section{II-6. Coal-Fueled Systems}

There are dozens of engineering studies in the literature on MCFC and SOFC power plants integrated with coal gasifiers. These have been sponsored by DOE, EPRI, the Japanese Government, and European utilities. The authors of all of these studies conclude that FCs coupled to coal gasifiers represent the most efficient uses of coal with the least environmental intrusion of any known technology. Consequently, this may become the ultimate application and the largest market of all for FC systems, although it represents a very unlikely entry market. A recently published report on coal-coupled systems was issued by EPRI and the generic results are as follows:

(i) Integrated gasification FCs (IGFCs) of $45-50 \%$ efficiency can be designed using commercially available gasifiers, gas clean-up systems and bottoming cycles.

(ii) IGFCs at $50 \%$ efficiency will produce approximately $20 \%$ lower solid, liquid and gaseous emissions than an integrated gasification combined-cycle (IGCC) power plant, as well as at least 35\% fewer solid, liquid and gaseous emissions (more than $90 \%$ lower acid-rain emissions) than pulverized coal plants.

(iii) The total capital investment for an IGFC is approximately $\$ 1800 / \mathrm{kW}$ (1992\$), which is not competitive with IGCC in the absence of larger environmental offsets than those currently available. Capital cost would have to be reduced by $\approx 20 \%$ to be competitive, and most of the cost reduction will have to be found through innovations in the gas clean-up systems and in the manner in which the FCs interface with the remainder of the plant. 
(iv) The specified IGFC capital costs are based on high-volume, learned-out production costs for the FC stacks. Obviously, the FC stacks must have been commercialized as parts of other systems before this type of coal use can occur.

It is not likely that the attractive efficiency and environmental characteristics of the IGFC will contribute to early commercialization of FCs due to the high specified capital-cost requirements. Also, very few coal plants of any type are being constructed at the present time. Only a handful of these on a worldwide basis incorporate coalgasification cycles and these are all demonstration-model plants. Coal gasifiers must be commercialized for power-plant use before an IGFC plant can be attempted and gasifier commercialization is not likely to be initiated as long as NG prices are low and supplies ample, which is expected to remain true over the time horizons of interest to this study.

\section{APPENDIX IIA: PROPOSAL FOR CONSTRUCTION AND OPERATION OF A NATIONAL FUEL CELL RESEARCH CENTER (NFCRC) ${ }^{*}$}

\section{IIA-1. The Vision for the NFCRC}

The NFCRC is an initiative spearheaded by Southern California Edison Company (SCE) and Southern California Gas Company (SCG) that aims to expedite FC commercialization. The objectives are to consolidate FC-system research and demonstration, promote competition, reduce duplication efforts of vendors, and promote communications between prospective manufacturers and users to reduce the developmental iterations needed for successful market entry.

It is proposed that the NFCRC headquarters be located at SCE's Highgrove Generating station in Grand Terrace, California, with initial support from SCE.

\footnotetext{
* The following people participated at discussions with AFC2WG members concerming the NFCRC: C. Bailey and R. Brown (Southern Califomia Gas Company), R. A. Figueroa (San Diego Gas \& Electric Co.) and J. Leeper (Southem Califomia Edison Co.).
} 
Highgrove has the necessary fuel, water, electrical facilities, and operating personnel to conduct demonstrations of $\mathrm{FC}$ power plants from many vendors on a consistent basis. The NFCRC anticipates being a "Center Without Walls" so that information from FCsystem tests conducted at other locations by other utilities on transportation, small-scalecogeneration, distributed-generation, and repowering applications can be shared by participants in the Center operation.

\section{IIA-2. Participants}

SCE is the proposed NFCRC host and principal sponsor. Other utilities, government entities and research organizations, i.e. GRI and others are expected to participate. Full participation with access to all NFCRC data is pegged to cost $\$ 750,000$ per year with a minimum 3-year commitment. Partial access, limited to individual tests, can be secured at lesser funding for the duration of the specific test project. Most of these funds would flow to the power-plant manufacturer; facility operating and overhead costs would be minimized. Potential participants include the following: (i) Utilities - SCE, PG\&E, SDG\&E, LADWP, SMUD, SCG, EPRI, GRI, and others; (ii) Government Agencies - DOE, DOD, SCAQMD, CALSTART, Cal Trans, LACMTA, DOT, etc.; (iii) National Laboratories and Universities (at reduced payment requirements).

\section{IIA-3. Candidate Projects}

SCE has purchased a $25-\mathrm{kW}$ SOFC system from Westinghouse that will be demonstrated on NG and diesel fuel during 1994. Other candidates include a 100-kW Westinghouse SOFC, a 1-MW MCFC from MCP, an ONSI PAFC unit, and a PEMpowered vehicle from Ballard. In most instances, substantial DOE or ARPA funding for construction of the power plants is anticipated. 


\section{IIA-4. Discussion}

SCE and SCG project that the NFCRC will reduce the overall cost of the national FC development and commercialization program. Their rationale is that duplicative BOP development efforts by competing vendors will be reduced; that the cost of the demonstrations will be reduced while the value of the data will be enhanced by using a cadre of experienced operators and technicians; and that the number of redesign and demonstration iterations a vendor needs to achieve for a market-qualified unit will be reduced. The NFCRC will also serve an important function as the principal information clearing house for the participating sponsors and manufacturers in several targeted applications.

Not everyone agrees with this projected commercialization cost reduction. Critics point out that the NFCRC will not replace the need for full-scale test facilities by each of the FC developers; the developer needs his own hands-on facility to work out powerplant designs and manufacturing procedures. Also, the value of the shared BOP equipment, i.e. water-treatment facilities, cooling towers, and even power conditioners contribute only small fractions of the cost of demonstration-model power plants. Some potential users have stated that shared data are not sufficiently compelling to make purchase decisions; these users require their own demonstration project on their own system.

Experiences with other national test centers does not provide any clear estimates of the value of NFCRC. The Battery Energy Storage Test (BEST) facility operated by PSE\&G did not result in any advanced load-leveling batteries being commercialized. This outcome is not a fault of the BEST facility because there simply was not enough progress made on any advanced batteries to justify constructing them for large-scale tests. Results from the Photovoltaic Design Information Center (PVDIC) operated by Sandia National Laboratories are more encouraging but still do not constitute a significant 
contribution to commercialization; this Center is recognized for good technical capability but utilities are not used to working with National Laboratories. As a result, the technical capability and hence the technology-transfer function are poorly utilized. Clearly, the NFCRC will not suffer from the BEST facility problem and the nature of the Application Center organizational approach would seem to address the PVDIC shortcoming.

First-of-a-kind FC demonstrations are expensive even at small scale. For example, the $25-\mathrm{kW}$ SOFC test at Highgrove will cost SCE over $\$ 4$ million. Because of the high cost, demonstrations almost always require support from consortia or collaborations. A difficulty with these projects is finding a willing host, with delays attributable to finding the host and establishing the consortium adding to the project cost. Clearly, SCE has short-circuited this process by having a consortium formed with a site available to all vendors.

Creation of the NFCRC is viewed favorably by many but not by all AFC2WG members. 


\section{INTERNATIONAL PERSPECTIVES ON SUCCESSFUL FC-SYSTEM COMMERCIALIZATION}

\section{III-1. Private- and Public-Sector Commercialization of FC Systems}

Issues in public- and private-sector commercialization have been discussed briefly in the Executive Summary (Sec. I-4). It was, in particular, emphasized that there are special reasons for public-sector support, namely, environmental cleanliness, exceptionally high fuel-energy-to-useful-energy conversion efficiencies, creation of hightechnology jobs, and the potential for very large exports over a prolonged period of time. FC systems embody the potential for greatly augmented efficiency in the conversion of fossil-fuel energy to electricity and heat, thereby reducing $\mathrm{CO}_{2}$ production per unit of useful energy output. Pollutant output at the user ends is minimal. In these respects, commercial FC systems with cogeneration are expected to be superior to all other operating systems using conventional thermodynamic cycles or their equivalents. Fuelcell systems may be used to generate electricity without the production of offensive concentrations of $\mathrm{NO}_{\mathbf{x}}$. Their operation generally requires fuel cleaning which also reduces to negligibly small levels such pollutants as $\mathrm{SO}_{\mathrm{x}}$ and particulates. When properly operating, HC emissions should become vanishingly small. Fuel-cell systems are being constructed in modular unit sizes that are singularly well adaptable to the production of distributed power. Furthermore, the use of FC systems is entirely compatible with the efficient long-range implementation of a hydrogen economy in which renewable or nuclear energy sources are used as primary inputs. Finally, selected FC versions (e.g., PEMFCs) appear especially adaptable for applications in the transportation sector. These are formidable advantages that have been well recognized and are ultimately responsible for continued public support of FC R \& D and for current world-wide FC-system commercialization efforts. It is apparent that if these devices become commercially 
successful, there will be important marketing potential for export to foreign buyers. It is no exaggeration to assert that a device that simultaneously dominates the stationary and movable power sectors represents unmatchable commercial value and the successful entries into this market will have business potential second to no ventures involving other devices or technologies.

The preceding arguments have, of course, been elucidated elsewhere, especially in Japan and Western Europe. Thus, successful FC-system commercialization in the U.S. implies an implementation schedule that will assure U.S. developers a competitive international market position. Federal funds have been expended on FC developments for at least 40 years. Cost reductions and product improvements have been achieved. Although some technical problems remain with some of the systems, the primary current issue is successful implementation of a large-scale commercialization effort to reduce costs, coupled with R\&D directed at product improvement.

\section{III-2. The Importance of Timing in Commercialization Schedules}

There is probably no more compelling lesson that can be learned from studies of many successful new commercialization ventures than the conclusion that the right device must enter the market at the right time. If a superior technology becomes available prematurely, it will not be bought; if it arrives too late, marketing will be impossibly difficult. International developments and externalities suggest that now is the right time for FC-system commercialization for the following reasons: Governments in all developed and in many developing countries, as well as the public at large, place very high value on non-polluting technologies. Distributed power generation with greatly reduced transmission-line lengths and increased conversion efficiency to electricity with associated reductions in $\mathrm{CO}_{2}$ emission are valuable $\mathrm{FC}$-system attributes. These externalities have dollar values that may be estimated by various means. If these 
valuations are properly made and explained, public support for FC-system commercialization may well be classified as a bargain purchase. Trading of emission loads has become standard practice for utilities, municipal-waste incinerators, and industrial establishments. For any given region at any given time, the applicable current dollar values of emissions are thus accurately defined.

\section{III-3. Servicing FC Systems at User Installations}

An important factor in commercialization failures is faulty servicing after hightechnology devices have been installed by manufacturers and system servicing has been turned over to non-expert personnel by the constructors, especially in foreign locations. Past experience with a variety of new technologies has shown that the diversity of faulty maintenance often exceeds the most generous allowances made by manufacturers, thereby causing excessive $O \& M$ costs with large and perhaps unacceptable financial losses. FC-system servicing will clearly become an important component of successful international market penetration. Familiarity with FC-system maintenance involving any type of design is the best insurance against avoidable costly repairs. This potential problem is not properly addressed by bringing one or more highly trained engineers to user locations on a temporary basis.

At the present time, manufacturers and their affiliates are generally the sales and service agents for their devices. The principal customers are electric and gas utilities. As FC-system costs are reduced and FC systems become cost-effective market entries without subsidies, intermediaries may appear and implement successful industrial commercialization for a wide range of applications.

An interesting development relating to international penetration of $\mathrm{FC}$ technologies is a recent agreement between Enron Corporation and IFC to market PAFCsystem-derived electricity at preferred locations. This type of marketing is likely to 
become increasingly prevalent as the use of FC systems penetrates remote and relatively inaccessible regions of the globe.

\section{III-4. International Cooperation and Competition}

As has been stated in connection with the Summary given in Table I-1, FCcommercialization is distinguished by both international cooperative developments and by proprietary entries in many countries.

Available information (see Appendix IIIA) on FC-construction schedules for PAFCs in Japan, Europe and the U.S. suggests that the likely near-term installed capacity in Japan will exceed that in the U.S. by at least a factor of 10 . Generally, a country with a dominant application schedule for the first available FCs (i.e. PAFCs) is also likely to dominate later (MCFCs and SOFCs) applications and, ultimately, production as well. Since only about one third of the total FC-system cost will be expended on the fuel-cell stack, early system experience implies early familiarity with the balance of plants (BOPs). The BOPs have commonalities for different types of fuel cells (compare Sec. IX-1).

Japanese and European utilities have a strong built-in advantage over U.S. utilities insofar as FC commercialization is concerned because of substantially greater fuel and electricity costs in these countries and because distributed power generation becomes more attractive in congested markets. The introduction of any new electricity-generating technology and of FC systems in particular implies substantial up-front capital costs, which will be recovered through fuel savings associated with increased efficiency of the new units. Because this capital recovery will occur more rapidly, actual costs to Japanese and European utilities are relatively lower than to U.S. utilities. This feature of the economic environment may provide a partial explanation for more ready past acceptance of FC systems by Japanese than by U.S. utilities. On the other hand, it is probably 
improper to view fuel and electricity cost differences as sole determining factors because long-term national goals also play important roles.

\section{III-5. Institutional Barriers}

Commercialization of the outputs of government-subsidized R \& D developments has often been accomplished successfully in Japan and less frequently in the U.S. These differences are noteworthy, their causes have been extensively discussed, and the solution must apparently be sought in terms of creation of new institutional structures that characterize a successful new capitalism in Japan. The interested reader may consult Ref. 1 for a full discussion of issues and perceptions relating to this problem. ${ }^{1}$

\section{III-6. International Issues Relating to the Commercialization of New Technologies}

The issues discussed in this section relate to generic problems faced by any inadequately capitalized enterprise seeking funds for commercialization of advanced technologies with long (i.e. more than 3 years) lead times. For these products, needed venture capital from public offerings in the U.S. may be difficult or impossible to obtain or, if obtainable at all, the cost to the developer may well be forfeiture of control of the company, often to a foreign organization. Undercapitalization of advanced technologies includes developments at both small and large companies. In the latter case, long-term support for ventures requiring years of capital infusions may be expected to receive continuing Board scrutiny and will be judged in terms of both their short- and long-term merits in competition with innumerable shorter-term opportunities that arise in any well positioned business. As the result, long-term funding for the commercialization of

${ }^{1}$ Politics and Productivity: How Japan's Development Strategy Works, 332 pp., Chalmers Johnson, Laura D'Andrea Tyson, and John Zysman eds., Ballinger Publishing Company, New York (1989). 
advanced technologies in U.S. industries is continuously under scrutiny, which may impair the long-term commitment needed for success.

Commercialization of advanced U.S. technologies is a component of international market developments. The international arena involves not only "small" and "large" U.S. companies but also "large" foreign companies with substantial annual profits, especially in such countries as Japan, Germany, Switzerland, The Netherlands, U.K., etc. The home bases for many of these companies are economic systems enjoying large favorable international trade surpluses, generally much larger share-price-to-earnings ratios than in the U.S. and relatively strong currencies. What is the cheapest and most efficient procedure for this type of company to commercialize an advanced new technology?

Because of the very high mortality of businesses based on promising technologies during the first few years of commercialization efforts, it is generally not good strategy to become a major participant immediately after the initial stages of a new discovery. It is cheaper and safer to leave funding of the early discoveries and inventions to agencies of the U.S. government (e.g., NSF, DOE, DOD, NIH, NASA, etc.) and of foreign governments as well. Some years after discovery, it will become clear which new inventions and discoveries offer significant long-term market potential. At this point in time, there will generally be an identifiable operating unit requiring a large infusion of funds. The cheapest procedure for profiting from this identifiable opportunity is to form a joint venture of some type that will assure access to the proprietary technology while safeguarding the interests of the original developer for some years to come. The joint venture may take many forms, e.g., marketing the technology in a defined area of the world, packaging the technology for general use, testing the technology at a preferred location, etc. Important features of any of these arrangements are urgently needed funds for the original developer and technology access at relatively low cost to the rich partner. Once technology access has been gained, it becomes generally feasible to improve the 
original product at relatively low cost and enter the market with what amounts to a modified competitive product, which is easy to accomplish for a partner with much larger financial resources than the original developer.

\section{III-7. Steps in FC Commercialization}

An extensive literature has been published on the developing niche market for FC applications, especially in distributed power generation. The preferred selection of FC systems will be based on as yet unsubstantiated assumptions about installed FC-system costs (e.g., $\$ 1500 / \mathrm{kW}$ capital cost for market-entry and $\$ 970 / \mathrm{kW}$ for commercial FCsystems) and performance (42-60\% LHV fuel-conversion efficiencies to electricity, stack reloads every 5 years, $65 \%$ capacity factor, etc.), as well as externalized non-traditional benefits (e.g., the benefits of distributed power sources and the values of low pollutant emissions). An interesting exercise is described in a recent EPRI publication dealing with quantitative comparisons of off-the-shelf diesel generators in the size range from 50 $\mathrm{kW}$ to $1.6 \mathrm{MW}$ and 2-MW FC modules. ${ }^{2}$ For a number of Electric Membership Corporations (EMCs) of Oglethorpe Power Corporation (OPC), system-related and sitespecific economic planning assumptions lead to the conclusion that the FC system (in this instance, the MCFC system of ERC) could become cost-competitive, especially at the postulated commercial FC-system costs. Furthermore, if cost and performance goals are realized, cost-competitive entries for central-station power generation may ultimately be in the offing. ${ }^{2}$

2 "Carbonate Fuel Cells and Diesels as Distributed Generation Sources - Economic Assessment of Application Case Studies at Oglethorpe Power Corporation," EPRI TR-102163, Project 1677-24, Final Report, prepared by Rula, Inc., Walnut Creek, CA for the Electric Power Research Institute, Palo Alto, CA (October 1993). 
Impacts of public policy and regulations on FC-system commercialization are described in Sec. VII. Here, it is sufficient to note that there are important lessons to be learned from discussions with field operators of installed FC systems who will provide detailed information concerning problem areas that have arisen because of lack of familiarity with FC-system technology by regulators and officials at the local levels in all countries. An important conclusion that follows from these discussions is the necessity for advancing a proper educational agenda for all of the many participants who will be involved while technology implementation proceeds from market entry to commercial success.

In the real world, the preceding remarks do not address the most important single issue for successful commercialization, namely, successful marketing. This important business function can only be developed after cost-competitive systems with proven records of performance have been documented through field installations.

\section{III-8. FC-System Commercialization in Japan and Europe}

The unique promises of FC-systems are now widely recognized and have led to world-wide R\&D, prototype-system demonstrations and commercialization efforts. A key issue facing U.S. developers is maintaining a competitive position in the international market place.

\section{III-8.1. FC-System Commercialization in Japan}

An especially useful input into these deliberations has been provided by recent annual U.S./DOE-Japan/AIST-ANRE exchange meetings. An excellent summary of the 1994 exchange visit was prepared by M. Singer and M. J. Mayfield of DOE after 
deliberations involving the entire participating U.S. delegation. ${ }^{3}$ The Summary of Ref. 3 contains the following paragraph: "Visiting experts from DOE, U.S. fuel-cell manufactures, researchers, and industry association users found the Japanese fully committed to fuel-cell development."

The Japanese government and large Japanese industrial concerns have embarked on an ambitious course to build commercial fuel cells of all types. The Japanese approach is technically conservative in the sense that no efforts or costs are spared in assuring operational success. This technically conservative approach tends to be expensive, considerably more expensive than the approaches that are being followed by U.S. developers who take all reasonable risks in order to conserve limited available financial resources. The Japanese approach to FC-commercialization may be compared with the past commercialization efforts followed by the U.S. Department of Defense in bringing new and advanced technologies to the point of successful incorporation into the defense arsenal: initially, a higher priority was placed on ultimately successful operation than on cost minimization.

In addition to large governmental expenditures, substantial resources appear to be forthcoming from internally generated funds supplied by some of the largest Japanese industrial companies. The preceding statement must be qualified by the observation that we do not have definitive information on internal developments and funding for FCcommercialization for Japanese concerns. However, remarks made during the exchange visits such as statements at Mitsubishi Heavy Industries that some 200 scientists and engineers are working on SOFC developments with company funds and that the level of this internal funding is on the order of U.S. $\$ 40 \times 10^{6} /$ year suggest that major Japanese

${ }^{3}$ For details, see the FAX sent from MJ. Mayfield (DOE/METC), which is a copy of a cable sent from the U.S. Embassy in Tokyo to Washington (February 15, 1994). 
companies are expending large resources, which may be expected to contribute to successful market entry later.

\section{III-8.2. FC-System Commercialization in Europe}

There exists a well defined FC-commercialization program in Europe, with seed money provided through the CEC (Commission of the European Communities) in Brussels, Belgium, and now strongly endorsed as a fuel-cell commercialization activity by the European Parliament. Each CEC-funded program must involve participants from at least two European Member States which provide $50 \%$ of the total governmental funding for industrial development; the CEC provides up to $100 \%$ of marginal costs involving services by university professors or purchases of special equipment. Funding is provided through the Joule, Brite and Thermie Programs. ${ }^{*}$ Funds received from the CEC and individual governments are greatly augmented through internal industry payments leading to perhaps $85 \%$ internal industry funding for preferred efforts. Two of the largest European industrial concerns have major activities on fuel-cell commercialization. Siemens (which is said to have spent upward of 100 million DM $\simeq U . S$. $\$ 68$ million of its own funds on FC development) seeks to provide turn-key electricity-generation stations for PAFC stacks purchased either from IFC or Fuji and is pursuing (with CEC funding of 3 million ECU for 3 years) a program to construct a $20-\mathrm{kW}$, planar SOFC stack by late 1995 in an effort that parallels a similar SOFC development at the Dornier division of DaimlerBenz (where CEC funding is 2.5 million ECU for two years). DaimlerBenz has concluded an important. worldwide agreement with Ballard to develop and commercialize the Ballard PEMFC for transportation applications and has successfully

\footnotetext{
* For 1992-95, total CEC funding amounts to 32 million ECU, of which 23 million ECU are allocated to 22 projects on basic stack research and system development(Joule Program), 7 million ECU are designated for 5 manufacturing processes (Brite Program) and 2 million ECU are allocated to 3 demonstration projects (Thermie Program); 1 ECU $=\$ 1.25$.
} 
demonstrated a fuel-cell-powered truck in Europe; its Domier division continues PEMFC developments for submarine applications. Contributors to the PEMFC commercialization effort include ECN (Netherlands Energy Research Foundation), Innovision in Denmark, BMW, Renault, and others. The total funding level for transportation applications of PEMFCs is expected to be finalized by year-end 1994. The Deutsch Aerospace Division of DaimlerBenz is a partner in the ERC MCFC demonstration and commercialization programs. For transportation applications, heavy emphasis is being placed on direct methanol vehicles. An independent evaluation at $\mathrm{BCN} \cdot($ Brandstofcel Nederland B.V. $=$ Dutch Fuel Cell Corporation) has led to the conclusion not to proceed with large-scale MCFC-demonstration plants in The Netherlands at this time. Discussions between a number of AFC2WG members and European researchers and industry representatives have convinced the AFC2WG participants that a well directed and rapidly escalating effort leading to FC commercialization is in progress and that the ultimate market capability of these developments will represent international competition to U.S. and Japanese entries.

\section{III-8.3. Factors Contributing to Uncertainties in Evaluating International Developments}

At the present time, answers to the following questions are unavailable: (i) What are the actual numbers of qualified scientists and engineers involved in fuel-cell developments in the U.S., Japan and Europe? (ii) What are actual expenditures at the R\&D, demonstration and commercialization levels from all sources in the U.S., Japan and Western Europe? (iii) How do current commercialization achievements compare in Japan, Europe and the U.S? The answer to this last question is especially ambiguous because of numerous cooperative development agreements for all types of FC-systems.

The leader in PAFC construction is IFC, with marketing in Japan performed by Toshiba. Many IFC FC-systems, including the largest plant (11 MW), are operating in 
Japan. The nearest competitor to IFC is Fuji in terms of delivered PAFC units. Japanese utilities have more extensive operating experience with FC-systems than utilities in the U.S. and Europe. The Fuji stacks appear to have operated well but apparently now require a retrofit because of problems such as heat-transfer management.

The leader in constructing tubular SOFCs is Westinghouse. Nearly all of the utility operating experience with this system has been accumulated in Japan.

The most ambitious demonstration-construction plans on MCFCs are those of ERC (with a 2-MW unit scheduled for start-up in 1995) and of MCP (with a 250-kW unit under construction). There is ample precedent showing that small, well managed, entrepreneurial companies are often fully competitive with much larger and better capitalized enterprises.

The worldwide R\&D efforts on planar SOFCs do not show U.S. participation at levels comparable to those in Japan and Western Europe (see Table I-1).

The leader in constructing commercial PEMFC-systems is the Canadian company Ballard, with related $R \& D$ an international enterprise supported by notable participants in all comers of the globe (see Table I-1).

The preceding brief summary remarks allow a variety of interpretations concerning the future of fuel-cell commercialization. Whatever these interpretations may be, we are certain that successful U.S. entries over the long term require the following action: An ambitious construction schedule for complete FC systems that will assure early and continued exposure of electric utilities, independent power producers and others to complete operating plants at a variety of locations and under highly diverse operational conditions.

\section{III-9. Strengths and Weaknesses of the U.S. Fuel-Cell Commercialization Effort}

There are both notable strengths and weaknesses in the U.S. FC- 
commercialization effort compared with those in Europe and Japan. We identify these here in the hope that our observations will lead to programs that capitalize on U.S. strengths and remedy the weaknesses.

\section{III-9.1. Pioneering $R \& D$ and Early FC Development}

Ten years ago, there would have been no question about the U.S. lead in basic FC R\&D and preliminary development. With increasing involvement of experts in all parts of the world, the evanescence of a lead in fundamental understanding has become apparent. This type of advantage must now be regarded as non-existent.

\section{III-9.2. The Role of Dedicated Private Companies Pursuing Pioneering Developments}

The growths of small companies through rapid demonstrations and commercialization of new technologies have often defined the landscape of the most successful entrepreneurs (see the manufacturers' contributions to Chapter $\mathrm{V}$ for views on this topic). In spite of the formidable competition represented by much larger and better funded competitors, there are many success stories. Hopefully, these can be repeated in the FC-commercialization program, which provides special challenges represented by the need to construct what amounts to a substantial electrical and chemical plant surrounding the fuel-cell stack.

\section{III-9.3. The Disadvantage of Dealing with Agencies that Have R\&D Goals as Opposed to Commercialization Goals}

MITI in Japan and the Thermie Program in Europe are squarely focused on the need to create a viable, competitive FC-system industry. By contrast, the U.S. Department of Energy, which has been the primary funding agency for FC developments in the U.S., is basically a funding agency for R\&D and traditionally stopped short of providing the needed support to create competitive industrial enterprises. The example of 
DOE has been followed also by EPRI and GRI in the fuel-cell programs, even though these industry-cooperative programs have clearly defined commercialization objectives; however, their commercialization efforts are constrained by the IRS tax code for 501(c)3 not-for-profit organizations. The new ATP effort of the U.S. Department of Commerce (NIST) could provide significant relief to FC developers if a substantial fraction of the available funds were dedicated to FC commercialization for a period of about 5 years.

Definitions of required changes, if any, in U.S. institutional structures to create an effective agency for implementation of FC-commercialization goals along lines followed traditionally by MITI in Japan and apparently now in the Thermie Program in Europe fall beyond the competence of this Working Group. A suitable group of experts might be convened by the National Academy of Engineering.

\section{III-9.4. The Disadvantage of Working in Large Industrial Concerns with Near-Term Bottom-Line Performance Requirements}

Analyst projections and Wall Ștreet evaluations relate to such short-term results that a commercialization effort requiring more than 3 to 5 years for achievement of good returns on investments simply cannot compete with shorter-term opportunities for financial gains. This problem is well recognized and its solution may well be a condition for the success of any measures designed to correct long-term U.S. balance of trade deficits. Its resolution falls beyond the scope of our study.

\section{III-9.5. The Disadvantage of Insecurity in Long-Term F unding for a Major Innovation}

Stable funding is an essential prerequisite for a significant commercialization effort. For the FC technologies, we see a requirement for product-improvement R\&D for each type of FC system that must have term periods of at least 4 to 5 years. Unfortunately, much shorter periods for support have been the rule. 


\section{III-9.6. An Educated Foreign View of the International Agenda for FC-System Commercialization}

It is axiomatic that implementation of remedies required to change the enumerated disadvantages is subsections III-9.3 to III-9.5 to advantages will greatly aid the U.S. FCcommercialization effort.

The following summary statements on the current status of commercialization efforts were made by P. Trezona of the World Fuel Cell Council* and merit repetition: "Potential (FC-system) users will not purchase fuel cells in volume unless the capital cost is competitive, operation and maintenance costs are known and an effective service infrastructure is available; financing will become available only if performance is guaranteed. To satisfy the preceding conditions, about $100 \mathrm{MW}$ of pre-commercial demonstration and field-test capacity must be installed over a three-year period. Implementation will require government commitment, leadership and support. Japan is organized and committed to make it happen. The U.S. is probably not." Further, "Europe is a potentially attractive market. The EU development is small and fragmented but major companies are involved in the development of multiple technologies. Users are showing increased interest in PAFCs."

\footnotetext{
* Frankfurt, Germany (June 20, 1994).
} 


\section{APPENDIX IIIA: A HISTORICAL OVERVIEW OF PAFC DEVELOPMENTS AND COMMERCIALIZATION IN THE U.S., EUROPE AND JAPAN}

\section{IIIA-1. Introduction}

The 1985 Report - The report ${ }^{1}$ of the Advanced Fuel Cell Working Group (AFCWG) is a summary of the state-of-the art of FC technology in mid-1985. It includes discussions of technologies then under development, which were classified by electrolyte as being phosphoric acid FCs (PAFCs), alkaline FCs (AFCs), solid polymer electrolyte FCs (SPECs) and which are now called proton-exchange membrane FCs (PEMFCs), molten carbonate FCs (MCFCs), and solid oxide FCs (SOFCs). Issues concerned with future developments and applications of FC types were identified, and progress on technical issues was reviewed. In 1985-86, the only systems for which any commercialization strategy was being addressed were the IFC pressurized PAFC electric utility units and unpressurized PAFC on-site units. The former was then being planned as an 11-MW commercial prototype, following demonstration of a $4.5-\mathrm{MW}$ unit operating at lower pressure. The latter had undergone completed demonstration tests as a series of 40$\mathrm{kW}$ units, which required modification and scale-up to $200 \mathrm{~kW}$.

The 1985 report addressed commercialization issues for the 11-MW pressurized PAFC and its more advanced successors in some detail up to the year 2005-2010..$^{2}$ It was anticipated that these successors would incorporate progressive improvements as a result of operating experience. It is useful to summarize the 1985 commercialization predictions for this technology and reexamine them in the light of today's changed circumstances.

\footnotetext{
1“Assessment of Research Needs for Advanced Fuel Cells," S.S. Penner ed., Energy-The International Journal 11, 1-230 (1986).

2 A. J. Appleby, Energy-The International Journal 11, 13-94 (1986).
} 
Pressurized PAFC Commercialization Issues in 1985 - In 1985, DOE and other U.S. Government agencies (e.g., NA.SA) saw the pressurized PAFC in the 10-MW class as a technology on the verge of commercialization for electric utility applications. This view was reflected by interests of EPRI and many electric utilities. GRI and many gas utilities saw the on-site PAFC in the 200-kW class as a prime candidate for cogeneration applications. Chapter 2 of Ref. 1 is a surnmary of early-1980s studies concerning the expected commercialization of the pressurized electric utility PAFC. ${ }^{2}$ It was believed that failure of the PAFC to be commercialized for electric utility applications might make it very difficult to commercialize the high-temperature FCs. ${ }^{2}$ The electric utility PAFC had a net heat rate of $8,300 \mathrm{Btu} / \mathrm{kWh}\left(45.6 \%\right.$ efficiency), ${ }^{*}$ with the expectation of achieving lower heat rates by improvements in systems design, catalysis and stack operating conditions.

The pressurized PAFC was still far up the learning curve (see Figs. 2.4-1 and 2.42 of Ref. 2): The first unit was expected to cost about $\$ 6,000 / \mathrm{kW}$ in mid-1994 dollars. The learning curve assumed in EPRI-generated studies given in Ref. 2 was shallow. It involved the use of an $87 \%$ fall in cost for doubling of production, i.e. the relative cost was assumed to fall as $\mathrm{kp}^{-0.2}$, where $\mathrm{k}$ is a constant and $\mathrm{p}$ is the relative production [i.e. $\mathrm{b}$ $=0.8$ in Eq. (XI-6.1) of this Report].

In 1985 , it was predicted ${ }^{2}$ that the cost of the pressurized PAFC would decline to the equivalent of $\$ 3,000 / \mathrm{kW}$ after production of about $100 \mathrm{MW}$ by late 1992 and to about $\$ 1,750 / \mathrm{kW}$ after production of $45500-\mathrm{MW}$ units by mid-1995. By 2005 , the capital cost was expected to fall to about $\$ 1200 / \mathrm{kW}^{* *}$

When the pressurized PAFC was developed in the 1970s and early 1980s, simple cycle gas turbines were available at low cost (about $\$ 250 / \mathrm{kW}$ in 1994 dollars) in units

\footnotetext{
*All heat rates are given as higher-heating values and represent the basis for fuel pricing. As is common practice with turbomachinery, all efficiencies quoted are based on the lower heating values (LHVs).

${ }^{* *}$ Unless stated otherwise, costs are given in mid-1994 U.S. dollars.
} 
from about 10 to $100 \mathrm{MW}$. Their efficiencies were about $25 \%$, and they were considered to be peaking machinery operating on NG, which in 1982 cost about twice as much as coal ( $\$ 4.00 / \mathrm{MMBtu}$ in 1982 dollars or about $\$ 5.80 / \mathrm{MMBtu}$ in mid-1994 dollars). The price of NG was predicted to escalate in current dollars at $7 \%$ per annum, close to the then-expected inflation rate. Thus, a pressurized PAFC with an efficiency of $45.6 \%$ appeared to possess some real advantages for operation on NG for intermediate-duty use, baseload power being provided by coal (then $\$ 1.60 / \mathrm{MMBtu}$ delivered in 1982 dollars) and nuclear plants. Because of their low efficiencies and the high cost of NG, peaking turbines were not considered to be competitive with a pressurized PAFC acting as an intermediate-load machine.

This point is illustrated in the 1982 EPRI Technical Assessment Guide, ${ }^{3}$ which assumed installed costs for simple-cycle, $25 \%$-efficient gas turbines of $\$ 450 / \mathrm{kW}$ or $\$ 700 / \mathrm{kW}$ as a combined-cycle machine with $40 \%$ efficiency. Figure 2.3 of Ref. 4 shows that a PAFC with a capital cost of $\$ 1200 / \mathrm{kW}$ would have been competitive with a combined cycle plant using 1982 capital cost, interest rate and fuel-cost assumptions.

Electric Utility FC Utilization 1985-94 - Since NG has been deregulated in the U.S., supplies have increased and costs have fallen from $\$ 5.80$ in 1982 to about $\$ 2.50$ per MMBtu today. Similariy, the cost of oil has fallen from $\$ 30-35$ to $\$ 20$ per bbl because of increased supplies. The cost of delivered coal has also fallen in real terms. Lower fuel costs mean that power-plant efficiency is now less important than in 1985 . It should be noted that fixed costs per $\mathrm{kW}$ for any given technology are reduced by lower interest rates.

In 1985 , the gas-turbine combined cycle (GTCC) was only beginning to be introduced into the electric utility-generation mix. NG was regarded as a scarce and

3 EPRI Staff, "Technical Assessment Guide," EPRI Report P-2410-SR. EPRI, Palo Alto, CA (May 1982).

4 A. J. Appleby and F.R. Foulkes, Fuel Cell Handbook.p. 42, Van Nostrand Reinhold, New York (1989). 
relatively costly fuel, which would become both scarcer and more costly in the future. Utilities were therefore reluctant to invest in baseload NG machinery. However, since 1985 and passage of the Clean Air Reauthorization Act of 1990, NG has not only become cheaper and more readily available but has also become more desirable for use because of low emissions of $\mathrm{SO}_{\mathrm{x}}$.

The 1978 Fuel Use Act had set New Source Performance Standards for large gas turbines of $75 \mathrm{ppmv} \mathrm{NO}_{\mathrm{X}}$ at $15 \%$ oxygen on a dry basis, with $150 \mathrm{ppmv}$ for small turbines (5 MW). Standards are now 55 ppmv. $\mathrm{NO}_{\mathrm{X}}$ emissions for post-1978 coal plants were set at $0.6 \mathrm{lb}$ and $\mathrm{SO}_{\mathrm{X}}$ at $1.2 \mathrm{lb}$ per MMBtu. The $1990 \mathrm{Clean}$ Air Act requires low$\mathrm{NO}_{\mathrm{X}}$ burners $(0.45 \mathrm{lb} / \mathrm{MMBtu})$ and imposes a national cap on $\mathrm{SO}_{\mathrm{X}}$ emissions that implies a reduction to $0.6 \mathrm{lb} / \mathrm{MMB}$ tu or less. These modified figures correspond to about $1890 \mathrm{~g}$ for $\mathrm{NO}_{\mathrm{X}}$ and $2500 \mathrm{~g}$ for $\mathrm{SO}_{\mathrm{x}}$ per $\mathrm{MWh}$. Substituting $\mathrm{NG}$ for coal to reduce capped $\mathrm{SO}_{\mathrm{X}}$ emissions is an attractive prospect, especially when it is combined with emissions trading.

Since 1985, the GTCC has been a moving target in terms of efficiency and emissions, with little change in the real installed cost. By 1988, GTCCs were available with an efficiency of $50 \%$ and low $\mathrm{NO}_{\mathrm{x}}$ emissions (20-40 ppmv at $15 \%$ oxygen on a dry basis or 300-600 g/MWh of $\mathrm{NO}_{\mathrm{X}}$ ). By 1991-1994, they were available with $9 \mathrm{ppmv} \mathrm{NO}_{\mathrm{X}}$ emission (15\% oxygen on a dry basis) at efficiencies up to $58.5 \%$ in a combined cycle (e.g., as a $160 \mathrm{MW}$ unit from Asea Brown Boveri, $\mathrm{ABB}$ ). The combined cycle machines cost about $\$ 750-850 / \mathrm{kW}$, i.e. about $50 \%$ of the cost of a clean coal plant and less than the cost of a large NG steam plant. The 9 ppmv $\mathrm{NO}_{\mathrm{x}}$ emissions figure (at $58.5 \%$ efficiency) corresponds to $115 \mathrm{~g} / \mathrm{MWh}$, only $6 \%$ of that of a coal plant. With emissions credits, GTCC capacity is very attractive. These machines have also become reliable with more than 1,000 hours of operation between forced outages; detailed inspections are now 
required after 8,000 fired hours, hot-section maintenance at 24,000 fired hours, and a major overhaul every 48,000 fired hours. ${ }^{*}$

The Electric Utility Commercialization Scenario, 1985-1994 - In the U.S. and elsewhere, GTCC units in 1985 were not considered to be competitive with dispersed PAFCs in the 11-MW class. This pressurized PAFC was expected to be non-intrusive and an ideal dispersed generator at the substation level for urban sites. In 1985, the pressurized PAFC was therefore considered to be desirable for both new sites and for repowering of old urban facilities. Its high introductory capital cost would be partially offset by accounting credits for reduced transmission lines, reduced emissions, improved grid operation, and short lead times to operation for small-scale, dispersed equipment. 2,4 By 1985, the generic FCG-1 11-MW unit had evolved into what was hoped to be a commercial design, the PC23.2,4 The 1985 report contained a "probable" 1994 scenario in which about 16 11-MW PAFC plants would be in operation or under construction at U.S. electric utilities with a marginal cost of about $\$ 1,800 / \mathrm{kW}$. In 1985 , it was believed that IFC would supply complete multimegawatt pressurized systems for electric-utility, dispersed-power generation and that about 30 11-MW units would be sold by $1994 .{ }^{2}$ The PC23 was offered to U.S. utilities and, by the end of 1988, it was expected that five units would be ordered (see Ref. 4, p. 614). For a number of reasons, all of the orders failed to materialize. Between 1985 and 1988, potential customers found that the proposed 11MW design was either too large or too small or had the wrong footprint for their sites. Another reason cited was unavailability of a suitable inexpensive fuel supply (e.g., refinery off-gas). For urban installations, the cost of space was a problem. For example, Consolidated Edison ${ }^{5}$ in New York City would have preferred a 100-MW, multi-story

\footnotetext{
*June 1991 data for the GE PG6541B, simple cycle, 51-MW unit; turbine inlet temperature $=1160 \mathrm{C}$; exhaust temperature $=545 \mathrm{C}$ at $16 \mathrm{C}$ ambient, efficiency $=30 \% ; 9$ ppmv $\mathrm{NO}_{\mathrm{X}}$.

5 J. H. Hirschenhofer, D.B. Stauffer, and R. R. Engleman, "Fuel Cells, A Handbook (Revision 3)," DOE/METC-94/1006 (DE94004072), National Technical Information Service, U.S. Department of Commerce, Springfield, VA (1994).
} 
installation. Similariy, the City of Palo Alto found that the costs of urban sites would be unacceptably high.

A part of the problem was the economic decline during the late 1980s. The oil crisis of 1974 impeded UTC's efforts to offer a $27-\mathrm{MW}$ pressurized PAFC to electric utilities when electricity demand had been rising by $7.2 \%$ per year. A transportable generator, which could be used until large central stations were built, appeared to make economic sense. However, the economic slowdown with no growth in electricity demand prevented further development of this large system.

No U.S. utility customers were found for 11-MW units at the introductory offering price. While many utilities found the FC generator attractive, it was judged to be acceptable only if its capital cost was right, i.e. about $\$ 750-850 / \mathrm{kW}$ plus whatever credits for dispersed operation were appropriate. Utilities also expressed concern about financial unknowns involved in operating a new and unfamiliar technology. Furthermore, the argument that stack technology would be expected to advance greatly over a five-year replacement period was not a persuasive argument.

As a consequence of order failures, IFC virtually abandoned marketing of the large, pressurized PAFC systems after 1990. However, an 11-MW pre-prototype based on the PC23 system design using IFC stacks and system design, Toshiba site engineering and a Japanese balance of plant (BOP) was built and has been operating in Goi, Japan. In spite of an accident, as the result of which only 12 out of 18 stacks continued to operate, this plant has performed well. In Europe, a 1-MW PAFC using stacks purchased from IFC, a reformer from Haldor-Topsøe and the BOP supplied by Ansaldo has been operating at full power in Milan since June 1994. While this operating experience is valuable, it represents only a small percentage of 1985 predictions of what was expected to be achieved by 1994. Furthermore, lack of funding to pursue pressurized PAFC development has reduced improvements in heat rate and stack power density below 1985 
predictions. Heat rates of $7730 \mathrm{Btu} / \mathrm{kWh}$ or even $7500 \mathrm{Btu} / \mathrm{kWh}$ (i.e. 49 or $50.5 \%$ efficiencies) were expected with further major development. ${ }^{2}$ The DOE program to improve pressurized PAFC technology was terminated in $1992,5,6$ at which time current densities had been increased by $20 \%$ to $243 \mathrm{~mA} / \mathrm{cm}^{2}$. Demonstrations were performed up to the short-stack level and included components of the proprietary "Configuration B" type mentioned but not described in the 1985 report. $^{2}$ Results showed a $40-\mathrm{mV}$ improvement at $216 \mathrm{~mA} / \mathrm{cm}^{2}$ above the average reported in 1985 with a lower IR drop, allowing operation up to $370 \mathrm{~mA} / \mathrm{cm}^{2}$ at $0.73 \mathrm{~V}$ in a short stack (cf. the single-cell data in Fig. 2.14-10 of Ref. 2).

After failure to commercialize the pressurized PAFC in 1988, the American Public Power Association identified dispersed fuel cells as a suitable future generation technology (Ref. 4, p. 614). The Association represented 2,200 small municipal utilities with a total capacity of $90 \mathrm{GW}$, the operators of which purchase $80 \%$ of their power and rely on 180 companies for transmission access. In October 1988, the Association published the NOMO (Notice of Market Opportunity), which announced interest in purchasing FC systems greater than $1 \mathrm{MW}$ and also smaller dispersed units as appropriate. After evaluation of responses to the NOMO, the MCFC commercialization plan developed by Energy Research Corporation (ERC) was selected for support by the NOMO utility participants. The ERC plan called for delivery of $100+\mathrm{MW} / \mathrm{yr}$ of MCFC systems with unit sizes of $2 \mathrm{MW}$, power plants that are more than $50 \%$ efficient when operating on NG, and costing $\$ 1500 / \mathrm{kW}$ before the year 2000 .

6 International Fuel Cells Staff, "Advanced Water Cooling PAFC Development," Final Report. DE/MC/24221-3130, International Fuel Cells. South Windsor. CT (September 1992). 


\section{IIIA-2. U.S. PAFCS for Stationary Applications, 1994}

Lack of interest in the pressurized PAFC for electric utility applications resulted in its abandonment by two U.S. developers (Westinghouse and Engelhard Industries). The Westinghouse pressurized, air-cooled stack technology, developed under license from ERC, has been purchased for applications with $\mathrm{H}_{2}$ (e.g., from the chlor-alkali industry) by the FuelCell Corporation of America. In 1992, Westinghouse planned to construct two $\sim 400-\mathrm{kW}$ stacks for operation on $\mathrm{H}_{2}$ for Norsk Hydro. However, only one was built and tested in the U.S. The FuelCell Corporation of America has announced that one $400-\mathrm{kW}$ unit operating on reformed NG will be built with the BOP designed by Gilbert/Commonwealth, Inc., of Reading, PA in a U.S. Government facility in Pennsylvania. Engelhard has licensed its PAFC technology to Fuji Electric. IFC remains as an important U.S. PAFC-system developer.

ONSI Corporation with majority ownership by IFC* is producing the $200-\mathrm{kW}$ PC25 ${ }^{\mathrm{TM}}$ atmospheric pressure, on-site cogeneration unit operating at about $40 \%$ electrical efficiency (about $82 \%$ total LHV efficiency). The prospects for large-scale market penetration by this unit, which was developed with support from the gas industry, appear to be good in 1994. The first version of the PC25 1985 report. $^{2}$ It was hoped that 100 units of the first production run would be sold, after investment in a plant capable of producing $10 \mathrm{MW}$ (50 units) per year starting in 1990, with expected expansion to $40 \mathrm{MW} / \mathrm{yr}$ (200 units/yr). The first pre-production run of the ONSI 200-kW unit (the PC25 $\mathrm{A}^{\mathrm{TM}}$ ) involved 56 demonstration units, 22 of which are in Japan, 1 in Korea, 10 in Europe, 13 in California, and 10 in other parts of the U.S. Total cumulative operating hours for the PC25A ${ }^{\mathrm{TM}}$ were 140,000 by September 1993 and 215,620 at the end of 1993 , with 38 operational units, a worldwide overall average

\footnotetext{
* ONSI Corporation is chartered to produce on-site cogeneration PAFC plants up to $1 \mathrm{MW}$. Minority
} stockholders in ONSI include Toshiba and CLC 
availability of $93.5 \%$ and a U.S. availability of $95.4 \%$. By May 1994, over 300,000 operating hours had been accumulated. The Sydkraft (Sweden), unit, delivered in June 1992, had operated almost 13,000 h by March 1994 without interruption. Its performance and degradation were within the expected norms based on stack bench testing. Only 7 days were needed from delivery to power generation on a prepared concrete pad. At the end of 1993, an SCG unit had accumulated $11,031 \mathrm{~h}$ at $92.3 \%$ overall availability. An Osaka, Japan, unit reached $10,716 \mathrm{~h}$ on the same date with $95.4 \%$ availability and had $5,476 \mathrm{~h}$ of continuous operation. The highest availability was $99.3 \%$ for a unit at the Pittsburgh International Airport (7,277 $\mathrm{h}$ at the end of 1993). An Irvine, CA, unit had $10,554 \mathrm{~h}$ at the same time, $96.4 \%$ availability; a unit at Brooklyn, NY, operated for 9,428 $\mathrm{h}$ at $94.9 \%$ availability. By June 1994 , two units had shown over $6,000 \mathrm{~h}$ of continuous operation. These units are continuing to operate at the cited availabilities.

By 1994, the PC25'M had gone through three stages of design evolution. In addition to the specified $56 \mathrm{PC}^{2} 5 \mathrm{~A}^{\mathrm{TM}}$ units, $18 \mathrm{PC} 25 \mathrm{~B}^{\mathrm{TM}} \mathrm{s}$ are being installed on military bases. The PC25C $\mathrm{C}^{\mathrm{M}}$ was expected to become available early in 1995 at $\$ 3,000 / \mathrm{kW}$ in 1995 US\$, a reduction of about $\$ 2,000 / \mathrm{kW}$ below the price of the previous version. The aim is to reduce the cost of commercial PC25D ${ }^{\text {mM }}$ units to $\$ 1,500 / \mathrm{kW}$ by 1998 . Units were expected to find the first cogeneration niche markets at a cost of $\$ 2,500 / \mathrm{kW}$. IFC has identified 100,000 buildings which meet their target criteria for PC25 the U.S., where a capital cost close to $\$ 1,500 / \mathrm{kW}$ with an installation charge of $\$ 375$ will be economically competitive. About half of these buildings have acceptable installation costs of $\$ 1,800 / \mathrm{kW}$.

For viable production, the initial output of $\mathrm{PC} 25^{\mathrm{TM}}$ units should total $10 \mathrm{MW} / \mathrm{yr}$ for three years, with increasing production thereafter. An investment or subsidy of about 
$\$ 150$ million will be necessary to achieve a production rate of 200 units per year and reduce the selling price to desired commercial levels. IFC has made a major effort to reduce costs, weights and volumes of components, which include heat exchangers, the stack, inverter, and reformer (see Secs. V- 1 and IX-1 for details). The PC25CrM weighs $40,000 \mathrm{lb}$ compared with $60,000 \mathrm{lb}$ for the $\mathrm{PC} 25 \mathrm{~A}^{\mathrm{m}}$. The dimensions have been reduced from $3.5 \mathrm{~m} \times 3.0 \mathrm{~m} \times 7.3 \mathrm{~m}$ to $3.0 \mathrm{~m} \times 3.0 \mathrm{~m} \times 5.5 \mathrm{~m}$.

Emissions from the PC25 ${ }^{\mathrm{TM}}\left(0.45 \mathrm{ppmv} \mathrm{NO}_{2}, 2 \mathrm{ppmv} \mathrm{CO}, 4\right.$ ppmv of total hydrocarbons at $15 \%$ oxygen on a dry basis) are negligibly small compared with California combustion-engine standards of $36 \mathrm{ppmv}$ for $\mathrm{NO}_{2}, 2000 \mathrm{ppmv}$ for $\mathrm{CO}$, and $250 \mathrm{ppmv}$ for reactive organic gases or ROG. As the result, the PC25 $2 \mathrm{M}$ received a blanket exemption from the California South Coast Air Quality Management District (SCAQMD). The hydrocarbon emissions were mostly methane (which is an important greenhouse gas but not an ozone-forming pollutant) and negligible amounts of higher hydrocarbons. The PC25A $\mathrm{A}^{\mathrm{TM}}$ emissions from the lean reformer burner are equivalent to $2.4 \mathrm{~g} / \mathrm{MWh}$ for $\mathrm{NO}_{2}$ and $6.5 \mathrm{~g} / \mathrm{MWh}$ for $\mathrm{CO}$, which are orders of magnitude below those for conventional combustion generating equipment.

The PC25C $\mathrm{CM}^{\mathrm{TM}}$ has an assured market niche for small NG-fueled cogeneration equipment in U.S. applications where it competes with delivered electricity and appropriate credit is given for on-site heat. When used with landfill gas, the operator will benefit from a $95 \phi / M M B t u$ tax credit.

\section{IIIA-3. European Dispersed-Power Applications of PAFCs}

Northern European generating capacity was first dominated by coal, which was then supplemented by oil. Next, nuclear power entered the market, especially after the OPEC oil crisis of 1974 . The French national nuclear program is a noteworthy example. With national nuclear embargoes (e.g., in Jtaly and The Netherlands) and nuclear slow- 
downs elsewhere (Germany, Britain), increasing availability of NG from the North Sea, Russia and North Africa, and because of increasingly severe emission regulations especially for acid rain, combined-cycle plants including cogeneration have become very attractive. As an example, The Netherlands had $4 \mathrm{GW}$ of cogeneration (combined heat and power, CHP) capacity in the 25 to $400 \mathrm{MW}$ range in 1994 as part of its tightlyintegrated grid serving 15 million people in an area of $42,000 \mathrm{~km}^{2}$, which is about $25 \%$ larger than Connecticut, Massachusetts, and Rhode Island combined and has $45 \%$ greater population.

The market for the PC25 $5^{\mathrm{M}}$ is now about $200 \mathrm{MW} / \mathrm{yr}$. The muffled noise levels of the latest units are very low $(45 \mathrm{~dB}$ at $50 \mathrm{~m})$. It has been estimated that the approximate cost of reducing emissions to currently required values in older units corresponds to an increase in electricity cost of only $0.25 \notin$ (U.S.)/kWh. The capital costs of these GTCC CHP units, with average electrical efficiencies of $50 \%$, was $\$ 750-850 / \mathrm{kWh}$. At costs of $\$ 1200 / \mathrm{kW}$ after 2005 according to 1985 projections, a $47 \%$ efficient pressurized PAFC will not be competitive on a cost-of-electricity basis with the CHP units. The installed systems are in the $25 \mathrm{MW}$ class or greater, whereas the planned pressurized IFC PAFCs are smaller than $11 \mathrm{MW}$. It should be noted that each large (100-150 MW) gas turbine unit represents a major capital investment.

Whether the on-site PAFC can compete in Europe will largely depend on its capital cost and on the evolution of small gas engines for CHP applications. The typical CHP-utilization requirement in Germany is $4,000-4,500 \mathrm{~h} / \mathrm{yr}$. If renewable fuels are used, the electricity produced has a minimum guaranteed price of $16.8 \mathrm{Pf} / \mathrm{kWh}(10.5 \varnothing$ U.S./kWh).

In mid-1994, The Netherlands and Germany had gas-engine CHP units in the 100 $\mathrm{kW}$ to $1 \mathrm{MW}+$ range. The majority $(85-90 \%)$ of Germany's total CHP capacity of 700 MW was in the several hundred $\mathrm{kW}$ range. About $100 \mathrm{MW}$ of small diesel capacity 
existed in Southern England. Small-scale CHP thus represents a large market. Compared with conventional equipment, it offers a $25-40 \%$ reduction in fuel costs and a $99 \%$ reduction in emissions. In the distributed CHP mode, it represents an advantageous way to reduce $\mathrm{CO}_{2}$ emissions, which are to be lowered by $25 \%$ in the residential sector by 2010. The PAFC produces $170^{\circ} \mathrm{C}$ steam, which is an ideal temperature for absorption chillers in the commercial sector and may be used with land-fill gas and bio-gas as fuels in such applications as waste-water treatment.

In a simplified and less capital-intensive form offering somewhat higher efficiency, the PAFC may be used where excess industrial $\mathrm{H}_{2}$ is available (e.g., along the German hydrogen pipeline system and in Italy) and where electricity from chemical byproducts (e.g., $\mathrm{H}_{2}$ ) is sold at premium prices. According to tradition, the chlor-alkali industry is expected to lease rather than buy FC generating equipment. Gas companies may use their own equipment to sell electricity and cogenerated heat to users such as hospitals, which do not want the responsibility of owning and operating their own equipment. This is the approach proposed in a joint venture by IFC and the gas-pipeline company Enron in the U.S. Hospitals and many other establishments, which are major users of electronic equipment, require high-quality, non-interruptible power and will be prepared to pay a premium for this application. This power is separate from the housekeeping load and can readily be provided by dispersed PAFC units replacing rechargeable batteries. Current concerns about EMF effects, as well as esthetic objections, mean that new transmission-line capacity is likely to be very limited. Finally, pollution concerns in city centers and in Eastern Europe, as well as resource pressures (80\% of oil is imported and $17 \%$ of Germany's energy requirements depend on NG at a time when the North Sea reserves are rapidly diminishing, for example, to 7 years of remaining supplies in the British zone), favor energy efficiency and cogeneration, preferably via FCs if the capital costs are acceptable. The grids in different European countries differ with respect to 
integration. A technology which may be appropriate for Eastern Germany, Southern Britain or parts of Italy is not necessarily appropriate in The Netherlands.

Advantages of the $\mathrm{PC} 25^{\mathrm{m}}$ are ultra-low $\mathrm{NO}_{2}, \mathrm{SO}_{2}$ and particulate emissions, as well as low noise without the use of elaborate muffling equipment. The low forced outage time will also be advantageous. According to the North American Electric Reliability Council Generating Unit Statistics for 1988-92, average run times before shutdown of fossil, geothermal, and nuclear plants were 600,500 , and 1,400 hours, respectively. Similarly, according to GRI figures, ${ }^{7}$ the average mean time between forced outages for reciprocating machines in the $60 \mathrm{~kW}, 80-800 \mathrm{~kW}$, and $>800 \mathrm{~kW}$ classes were approximately 500, 250, and 350 hours, respectively. For combustion turbines in the 1-5 MW, 5-25 MW, and >25 MW classes, they were approximately 150 , 675 , and 1,000 hours, respectively. In contrast, the mean time to planned or forced outage for operational PC25A $\mathrm{A}^{\mathrm{TM}} \mathrm{s}$ was 1,500 hours, with 2,700 hours expected for future units.

The major issue is cost of power. Small diesels have electrical efficiencies of 36$39 \%$ compared with about $40 \%$ for the PC25 ${ }^{\mathrm{mM}}$. Their capital costs were about DM $3,000 / \mathrm{kW}(\$ 1,875 / \mathrm{kW})$ in the $40-50 \mathrm{~kW}$ class, which was developed for the residential market but was not widely installed. In the $200-500 \mathrm{~kW}$ and $>1 \mathrm{MW}$ classes, the installed costs were about DM 2,000/kW (\$1,250/kW) and DM 1,500-2,000/kW (\$9501250/kW). The operational lifetimes of these units are 40,000 hours as for PAFC stacks; the BOPs have expected 30-year lives. The smallest CHP unit in the $6-7 \mathrm{~kW}$ class is intended for domestic applications and costs DM 3,000-4,000/kW $(\$ 1,875-2,500 / \mathrm{kW})$. In many applications, $\$ 2,500 / \mathrm{kW}$ for PAFC systems will be acceptable.

7 “Reliability of Natural Gas Cogeneration Systems," January 1990-September 1992, GRI, Chicago, IL (1992). 
Anticipating a large mature European PAFC market, CLC srl, an Ansaldo (Italy) subsidiary, has taken a license to 1998 from IFC-ONSI to manufacture and sell the PC25 Europeanized PC25 $\mathrm{mM}$ to different standards from those of the U.S. model in order to comply with differing European regulations. During the first year, CLC will import complete PC25 ${ }^{\mathrm{TM}} \mathrm{s}$ from the U.S. In the second year, European-manufactured BOPs will be used with stacks imported from IFC-ONSI. Subsequently, complete stacks will be manufactured in Europe for integration with European BOPs. By 1994, European graphite vendors had been identified and stack parts were being manufactured by CLCAnsaldo. A $50 \%$ efficient hydrogen-powered unit is being offered at $\$ 2,000 / \mathrm{kW}$.

\section{IIIA-4. The PAFC in Japan}

Japan has a large steam-generating capacity using imported LNG, and some of this will be supplemented by new GTCC capacity. In the early 1980 s, it was believed that PAFCs were suitable for small-to-medium power-generation applications. Japanese organizations have been developing PAFC units for electric utility and on-site use since 1980 with 50\% funding from the New Energy and Technology Agency (NEDO) of the Ministry of International Trade and Industry's (MITI's) Moonlight Program. ${ }^{2}$ Major activity during the late 1980s involved demonstrations of 1-MW-class pressurized units and development of $200-\mathrm{kW}$ on-site units with $0.37-\mathrm{m}^{2}$ cells. During 1987 and 1988 , the 1-MW Chubu unit located at the Chita Power Plant (2 Toshiba and 2 Hitachi stacks, 6.3 atma and $205 \mathrm{C}$ ) operated for 1,018 hours, while the 1-MW Kansai unit [2 Fuji Electric and 2 Mitsubishi Electric (Melco) stacks, 4 atma, $190 \mathrm{C}$ ] operated for 2,045 hours. There were, however, operational problems with these plants.

Except for Tepco's 11-MW Goi plant, the next stage of pressurized PAFC development in Japan was expected to be operation of the 5-MW Fuji Electric Kansai 
unit, which will occupy three floors of one building. This unit operates at 7.2 atma (106psia), $205 \mathrm{C}, 0.75 \mathrm{~V}$, and $300 \mathrm{~mA} / \mathrm{cm}^{2}$ using $0.8-\mathrm{m}^{2}$ cells. In 1992, power production was expected to start in April 1994. Operation is now anticipated by mid1995. This 5-MW unit has a reformer of the Haldor-Topsøe design licensed to Kobe Steel.

The PAFC Research Association (a consortium of Tokyo Gas, Osaka Gas, Toho Gas, and Saibu Gas) and a number of electric utilities have been supporting Toshiba to design and build an atmospheric pressure, 1-MW, NG PAFC unit with two $550-\mathrm{kW}, 1-\mathrm{m}^{2}$ stacks for operation in 1995-96 in an office building in Minato-ku, Tokyo. ${ }^{8}$ The specification calls for $40 \%$ electrical and $79 \%$ total efficiencies. Toshiba built a $1-\mathrm{m}^{2}$ stack-production facility in 1990. Commercial Toshiba utility plants will have a 0.08 $\mathrm{m}^{2} / \mathrm{kW}$ footprint and a $1.1 \mathrm{~m}^{3} / \mathrm{kW}$ volume to allow installation in the basements of downtown buildings. The stack will be increased to $1.1 \mathrm{MW}$ from the $670 \mathrm{~kW}$ of the $\mathrm{PC}^{2} 3^{\mathrm{TM}}$ stack and it will also have a transportable reformer in the $11-\mathrm{MW}$ class. ${ }^{9}$

Following the 1-MW developments, Fuji Electric and Melco continued developing on-site units, while Toshiba remained a minority shareholder and maintained its working relation with IFC. Toshiba invested with IFC to establish ONSI in 1990. Fuji Electric decided to concentrate on $50-\mathrm{kW}$ on-site units in the late $1980 \mathrm{~s} .{ }^{10} \mathrm{~A}$ detailed report on the early Fuji Electric FP-50 unit at Tokyo Gas was presented at a meeting in Washington in 1990.11 It was started up in April 1990 and had operated for 2500 hours by the end of August when it was shut down. Manganese dioxide is used instead of zinc oxide as a chemical desulfurizer. Its reformer is a compact, single-burner,

${ }^{8}$ K. Kimoto, International Fuel Cell Conference Proceedings, p. 5, MTTI, Tokyo (1992).

9 H. Kawahara, Ext. Abst., "1990 Fuel Cell Seminar," Phoenix, AZ, November 1990, p. 491, National Fuel Cell Coordinating Group, Washington, DC (1990).

10 R. Anahara, J. Power Sources 37, 119 (1991).

11 K. Usami, H. Tomei, Y. Mizumoto, M. Matsumoto, and T. Murahashi, Ext. Abst. "1992 Fuel Cell Seminar," Tucson, AZ. November 1992, p. 366, National Fuel Cell Coordinating Group, Washington, DC (1992). 
single-tube system, and it incorporates five heat exchangers in two units using plate-andfin technology. It had an optimum electrical efficiency of about $41 \%$ (LHV) with a heatrecovery efficiency of about $35 \% .12$

Melco began to operate a 200-kW unit at the Plaza Hotel, Osaka, in March 1990. On completion of government-industry and privately sponsored tests (October 31, 1991), 13,038 generating hours $(1,797 \mathrm{MWh})$ had been accumulated with 60 start-ups and a maximum continuous run of 2,656 hours. The electrical efficiency was $40.0 \%$ at full load $(89.5 \%$ total) and $35.0 \%$ at $25 \%$ load $(76.0 \%$ total). Performance degradation was less than $5 \%$ over the total operating time and $7 \%$ projected to 40,000 hours. ${ }^{13,14}$ The unit reportedly weighed $25 \mathrm{mt}(55,000 \mathrm{lb})$. Its measured $\mathrm{NO}_{2}$ emissions were $4 \mathrm{ppmv}$ at $7 \%$ $\mathrm{O}_{2}$ with negligible $\mathrm{SO}_{2}$ and particulates.

Melco has achieved improved performance and stability with time. ${ }^{15}$ The average decay for the latest water-cooled PAFC stacks was less than $2 \mathrm{mV} / 1000$ hours, with a $7 \%$ reduction in performance expected after 40,000 hours (from $650 \mathrm{mV}$ to $600 \mathrm{mV}$ at 200 $\mathrm{mA} / \mathrm{cm}^{2}, 1$ atma, $205 \mathrm{C}, 80 \%$ and $50 \%$ fuel and oxidant utilizations, respectively). Data ${ }^{14}$ are also available on the Hokkaido Electric Power $100-\mathrm{kW}$, methanol-fueled pilot plant for use on isolated islands, which operated 4,575 hours (330 MWh) to August 1990. Its total HHV efficiency was $79 \%$ ( $36 \%$ electrical with $37.1 \%$ at the beginning of operation). This unit was subjected to 245 stop-start cycles, with a start-up time of 2 hours (cold) and 1.5 hours (hot). Its load-following ramp was $30 \%$ per minute (twice the requirement) and $\mathrm{NO}_{2}$ emissions were under 1 ppmv. Further technology reviews ${ }^{16,11}$ showed a $50 \%$ increase in current density (to $\left.300 \mathrm{~mA} / \mathrm{cm}^{2}\right)$ in sub-scale $\left(100 \mathrm{~cm}^{2}\right)$ cells, which was to be

\footnotetext{
12 M. Kamikaze, S. Kaneko, and M. Ikeda, p. 330 of Ref. 9.

13 T. Omoto, H. Tomei, Y. Yuasa, and H. Yamazaki, p. 334 of Ref. 9.

$14 \mathrm{H}$. Yamamoto, Y. Matsumoto, and Y. Mizumoto, "International Fuel Cell Conference Proceedings," p. 91, MITI, Tokyo (1992).

15 H. Ishiokam T. Koshimizu, H. Miyoshi, and Y. Mizumoto, p. 318 of Ref. 9.

${ }^{16}$ M. Matsumoto, K. Usami, and T. Murahashi, p. 133 of Ref. 14.
} 
confirmed in $0.36-\mathrm{m}^{2}$ stacks. The $200-\mathrm{kW}$ on-site unit was made more compact. The volume was decreased from $0.16 \mathrm{~m}^{3} / \mathrm{kW}$ in the 1989 Plaza Hotel unit, which operated at $150 \mathrm{~mA} / \mathrm{cm}^{2}$ with a steam-carbon ratio for reforming of $3.5: 1$, to $0.15 \mathrm{~m}^{3} / \mathrm{kW}$ in the later 1991 version $\left(200 \mathrm{~mA} / \mathrm{cm}^{2}\right)$, to $0.12 \mathrm{~m}^{3} / \mathrm{kW}\left(250 \mathrm{~mA} / \mathrm{cm}^{2}\right.$, steam-carbon ratio $\left.=3: 1\right)$ in 1994; the present goal is $0.08 \mathrm{~m}^{3} / \mathrm{kW}\left(300 \mathrm{~mA} / \mathrm{cm}^{2}\right.$, steam-carbon ratio $\left.=2.5: 1\right)$ in 1996 and beyond. The decrease in steam-carbon ratio will raise the output of $170 \cdot \mathrm{C}$ steam successively from $18 \%$ to $21 \%$ to $25 \%$. All plants after 1992 had fully automatic controls.

A $200-\mathrm{kW}$ version of the Fuji Electric power plant was designed to use methanol for applications on 300 inhabited small islands off the main Japanese coast, in conjunction with diesel generators and photovoltaics. The efficiency of this version was $44.0 \%$ at full load, $45.0 \%$ at $75 \%$ load, and $40.7 \%$ at $50 \%$ load. $\mathrm{NO}_{2}$ emissions were 2 ppmv. By August 31, 1990, it had operated for 3,600 hours and had produced $493 \mathrm{MWh}$ at the Okinawa Electric Power Company location on Tokashiki Island. 17 By September 1993, it had operated for 8,449 hours. ${ }^{10}$ The Kansai Electric Power Company (Kepco) installed six 50-kW Fuji NG units on Rokko Island near Kobe by November 1991 for tests in conjunction with solar and wind-power facilities. Eight additional units and a Mitsubishi Electric 50-kW unit were installed by March 1992. Operations were continued through the end of 1993.

By the end of 1991, utilization of the six generators had been around $85 \%$, generating time had averaged about 5,000 hours, and the average continuous generating time was about 1,200 hours. There were 187 operating stoppages. Improvement is clearly required. ${ }^{18}$ Two 50-kW Fuji Electric units (delivered in 1989 and 1990) have

${ }^{17}$ T. Nogi, T. Toma, and H. Yamazaki, p. 322 of Ref. 9.

18 A. Kitamura. K. Nakaji, and H. Matsuda, p. 99 of Ref. 9. 
been operating on desulfurized naphtha at the Idemitsu Kosen Co. ${ }^{19}$ These Fuji Electric stacks were water-cooled. A $50-\mathrm{kW}$ Fuji Electric stack with dielectric liquid cooling is used for the U.S. methanol-reformer bus project. Over 100 PAFC units were installed in Japan by the end of 1993. At Rokko Island alone, there were $1450-\mathrm{kW}$ Fuji units and one 200-kW Mitsubishi unit. At the end of 1993, Fuji Electric had orders for over 65 onsite 50 to $500 \mathrm{~kW}$ PAFC units with a total capacity of $10 \mathrm{MW}$. The longest cumulative running time on any $50-\mathrm{kW}$ unit was then over 20,000 hours. There are also four $50-\mathrm{kW}$ Fuji systems in Europe (at Enagas in Spain, at SNAM/Eniricherche in Italy, and at the Swedish utilities Vattenfall and Sydcraft). Following some problems involving selfcommutation of the inverter when it sensed line fluctuations, the Sydkrafk unit (installed in November 1991) performed well. After May 1993, it operated continuously for 4,300 hours from June to November 1993; a total of 7,000 hours of operation were completed in February 1994. Two 25-kW PAFC Fuji stacks were assembled into systems by KTI in The Netherlands under Italian-Dutch-CEC sponsorship. Further work on this collaboration has reportedly been discontinued. The Bavarian Solar Energy Project (Bayernwerk, BMW, Linde, and Daimler-Benz), with $250-280 \mathrm{~kW}$ of amorphous silicon photovoltaics and a 50-kW electrolyzer will also include a 70-kW Fuji-KTI, $\mathrm{H}_{2}$-fueled PAFC system.

At the 1993 Grove Fuel Cell symposium in London, R. Anahara, then Executive Chief Engineer and director of Fuji Electric's FC-development program and now Secretary-General of the Japanese Fuel Cell Development Information Center, Chiyoda$\mathrm{ku}$, Tokyo, stated that the R\&D philosophy adopted by the Japanese Government was different from that elsewhere. It could be characterized as "Total Development" involving MITI, NEDO, the electric and gas utilities, and manufacturers, with full

${ }^{19}$ T. Yanagino, H. Matsumoto, B. Kariya, N. Kadoya, and E. Yoshino. p. 79 of Ref. 14. 
assessment of all aspects of development including safety (e.g., explosion testing of reformers) and improvements of burners.

The FC-industry development in Japan has been helped by an enlightened attitude of electric and gas utilities and by the fact that the FC developers are vertically integrated electric equipment manufacturers possessing expertise in areas ranging from robotics to electronic controls. Goals for successful commercialization include increased power density, longer stack life, improved current-density distribution, acid management and materials, as well as plant simplification and standardization, improved mass-production techniques, and quality control.

Japan has supported extensive demonstrations and testing of U.S.-manufactured PAFCs. In 1994, there were a total of 22 U.S.-made PAFC units operating in Japan.* Early units were tested at Tepco, 20, 21 Osaka Gas, ${ }^{22}$ and Nippon Petroleum Refining Co. ${ }^{23}$ The two Tepco units had operated for 5210 (876 MWh) and 3780 hours (409 MWh) with 1393 and 409 continuous hours, respectively, by August 1990.20 The first Tepco unit at the Shin Tokyo thermal power plant operated until 1990. A second was installed in a building in Shibaura, Tokyo, in March 1989 and was transferred in August 1990 to the Shibaura District Heating and Cooling Plant. By November 1991, it had operated 11,141 hours $(1,059 \mathrm{MWh})$ with a continuous run of 3,245 hours, a world record at that time. The average gross $\mathrm{AC}$ efficiency was 35.5 to $38 \%$, but the net $\mathrm{AC}$ efficiency was only $23-27.5 \%$. The sum of the electrical and heating efficiencies was 67 to $70.5 \%$. $\mathrm{NO}_{2}$ emissions were 13 ppmv, well below the 25 ppmv target. The cell voltage showed a drop of $6.5 \%$ per 1000 hours, which may conceivably have been related to system shutdowns. Future requirements include changes to attain improved system stability and

\footnotetext{
* An ONSI PAFC is also operating at the Korea Gas Corporation.

20 T. Makate, K. Ohkawara, H. Maebayashi, M. Abe, and Y. Usami, p. 338 of Ref. 9.

21 H. Maebayasi, S. Onoderas and Y. Kanai, p. 95 of Ref. 14.

22 M. Harada, N. Hahimoto, Y. Tanohata, and S. Sugiura, p. 338 of Ref. 9.

23 S. Yanagida, T. Siori, and S. Satake, p. 326 of Ref. 9.
} 
lower cost and parasitic power at part load 21 The PC25 ${ }^{\mathrm{TM}}$ has been greatly improved in later units with respect to emissions, efficiency, and decay rate. The early Osaka Gas unit had operated in the Umeda Center Office building for 3,800 hours by July 1990.22 The 130-kW PC25 ${ }^{\mathrm{m}}$ YX-2N at the Nippon Refining Company had enhanced desulfurization for operation on low-sulfur naphtha (boiling range $28-72 \mathrm{C}, 0.1-0.3 \mathrm{wt}$. ppm S). It had operated for 4,808 hours by the end of 1991 at an average load of $106 \mathrm{~kW}$. A different system was eventually operated on No. 1 kerosene (boiling range $=190-258 \mathrm{C}, 10-100$ wt. ppms using a Haldor-Topsøe kerosene reformer). ${ }^{23}$

Japanese PAFC Markets - In 1990, Abe et al ${ }^{24}$ estimated that the Japanese market for the PAFC would be 10 to $100 \mathrm{MW}$ before the year 2000 and MCFC deployment should reach $10 \mathrm{MW}$. For 2010, 1-2 GW were predicted for the PAFC. Subsequently, additional market segments were identified. Fukutome 25 quotes studies conducted by the Agency of Industrial Science and Technology (AIST) and NEDO using imported LNG at a cost of $4 ¥ / \mathrm{Mcal}(956 ¥ / \mathrm{GJ}, 1008 ¥ / \mathrm{MMBtu})$. For an exchange rate of $135 ¥ / \$$ (98 $¥ / \$$ in July 1994), plant break-even costs are considerably higher than U.S. figures. The capital cost of an LNG steam boiler plant with $37 \%$ efficiency is $¥ 210,000 / \mathrm{kW}$, and the benchmark cost for an industrial diesel cogeneration plant (30-year life) operating at $30 \%$ efficiency is $¥ 220,000 / \mathrm{kW}(\$ 2240 / \mathrm{kW}$ in mid-1994). For a 2-year stack life, break-even costs for dispersed FC plants with cogeneration operating at $43 \%$ electrical efficiency were $¥ 190,000 / \mathrm{kW}(\$ 1407 / \mathrm{kW})$; for a 5 -year stack life, they were about $\$ 2750 / \mathrm{kW}$. Transmission and distribution credits of $¥ 15,000 / \mathrm{kW}(\$ 110 / \mathrm{kW})$ were assumed.

The permitted cost of a central station FC plant with 5-year stack life operating at $43 \%$ efficiency was $¥ 180,000 / \mathrm{kW}$. Fukutome ${ }^{25}$ concluded that the PAFC will succeed as

24 T. Abe, Y. Izaki, T. Watanabe, Y. Mugikura, and K. Shimazu, in J. R. Selman, H. C. Maru, D.R. Shores, and I. Uchida eds., Proceedings of the Second Symposium on Molten Carbonate Fuel Cell Technology, Seattle, October 1990, p. 16, The Electrochemical Society, Pennington, NJ (1990).

25 A. Fukutome, J. Power Sources 37, 53 (1991). 
a dispersed technology, whereas the MCFC will become a central-station technology with increased capital cost and higher efficiency. For use as a detached generator on remote islands, the break-even cost will be $¥ 220,000-260,000 / \mathrm{kW}$ and, therefore, the PAFC is now cost-competitive. The PAFC capital cost is relatively less important in Japan than in the U.S., even at an OECD purchasing power parity (PPP) exchange rate of $¥ 200$ per dollar.

District-heating systems in Japan currently represent only about $0.5 \%$ of the total heat demand. With cogeneration, 1,040 MW/yr of PAFC systems may be used in urban redevelopment areas by the year 2000 and $840 \mathrm{MW} /$ year in new town areas. Customerowned units supplying CHP in new buildings were projected for 1, 3 and $5 \mathrm{MW}$ sizes. Units in the sub-MW range (e.g., the IFC PC-25 200-kW units) were not considered. The estimated markets for these PAFC units were 510,220 and $160 \mathrm{MW} / \mathrm{yr}$, respectively, by the year 2000. Thus, Fukutome 25 identifies total potential Japanese PAFC markets of $2400 \mathrm{MW} / \mathrm{yr}$ with cogeneration by the year 2000 .

In June 1990, MITI published a long-range estimate for Japan's future energy supplies and demands. It was expected that GNP and energy demand could be decoupled by enforcement of conservation policies, which would reduce the GNP-to-energy-use ratio from the present 0.98 to 0.42 , i.e. doubling of the GNP would increase the energy demand by about $33 \%$. To meet this goal, FC-system capacity with cogeneration will have to be increased from $150 \mathrm{MW}$ to $10.5 \mathrm{GW}$ by the year 2000 .

The Supply and Demand Committee of the Electric Power Industry proposed accelerated nuclear capacity and introduction of an optimized mix of power plants, including dispersed power generation using renewable energy sources with large FCgeneration capacity. The goal is $2,250 \mathrm{MW}$ of FC (mostly PAFC) capacity in 2000 , with $900 \mathrm{MW}$ for commercial use, $300 \mathrm{MW}$ for industrial use and 1,050 MW of dispersed capacity. The target cost for dispersed units is about $\$ 1,250 / \mathrm{kW}$ at the PPP exchange 
rate. By $2010,2,800 \mathrm{MW}$ should be in commercial use, which corresponds to only about $10 \%$ of the potential market identified in the AIST-NEDO report. Industrial use will be 2,400 MW and utility use 5,000 MW with PAFCs supplying 3,100 MW. New, hightemperature fuel cell (HTFC) technologies provide the remainder of the proposed total of $10,200 \mathrm{MW}$ of installed FC capacity.

In view of the size of the potential market, MITI and NEDO were encouraging Hitachi to reenter PAFC development and manufacturing. In addition, the Japanese Government was supporting the PAFC by paying up to one-third of the installation cost for $1992-94 ; 26$ only $¥ 800$ million had been appropriated for this purpose at the beginning of 1992. At the 1993 Grove Symposium, Anahara stated that cumulative spending on FCs through the year 1996 (in million will be 2,590 for $100 \%$ government-financed basic R\&D and 13,509 for pilot plants, 4,650 for demonstration plants with $50 \%$ government subsidies, and 1,270 for field trials with $33 \%$ government subsidies involving construction and operation of PAFCs in Japan during 1992-94. The specified subsidies also apply to FC power plants built by off-shore developers. According to Anahara, Japan expects to have eventually $30,000 \mathrm{MW}$ of central FC power generation (in sizes from $50 \mathrm{~kW}$ to $11 \mathrm{MW}$ ), 15,000 MW of gas-utility, on-site capacity (from $12.5 \mathrm{~kW}$ to 1 $\mathrm{MW}$ ), and 1,000 MW of other capacity (in sizes from 4 to $200 \mathrm{~kW}$ ). It seems now doubtful that the PAFC industry can be expanded at the necessary rate to fill the proposed market growth.

26 O. Yamamoto, H. Tajima, and S. Ohga, p. 46 of Ref. 11. 



\section{MARKET PERSPECTIVES ON FC-SYSTEM COMMERCIALIZATION}

The following is an overview of the market for FC-system commercialization in stationary power applications. It should be noted that segmentation of these markets is described by application rather than by end-user or supplier. In the past, FC systems were thought to be the exclusive domain of electric and gas utilities. It is, however, becoming increasingly clear that these entities have no franchise to the FC technology, although they are expected to play important roles in this emerging market.

(i) Onsite Systems - representative requirements range from a few tens of $\mathrm{kW}$ to a few MW. These small units may be located either on the customer side or on the utility side of the meter and users are expected to include private residencies, commercial office complexes, hospitals, and industry.

(ii) Substation Systems (including Industrial Cogenerators) - requirements range from a few hundred $\mathrm{kW}$ to perhaps $50 \mathrm{MW}$.

(iii) Central-Station Systems - requirements range from about $50 \mathrm{MW}$ to hundreds of $M W$.

\section{IV-1. Competing Technologies}

For each power range, there are competing technologies at capital and operating costs per $\mathrm{kW}$ of output well below those that can currently be met with FC systems. In particular, turbine costs have generally declined with inflation and remained constant in current dollars.

Combustion systems burning NG are widely used in large conventional systems and will be difficult to replace. It is noteworthy that current NG costs are well below $\$ 5 / \mathrm{MMBtu}$ and this is likely to remain the case (with proper adjustment for inflation) until well past the year 2020. New reheat turbines (GT24 and GT26) are available from 
$\mathrm{ABB}^{1}$ in various size ranges with power outputs of $250 \mathrm{MW}$ at LHV efficiencies in combined-cycle operations of 58 to $59 \%$ and will presumably be offered for sale at competitive prices in the range of $\$ 600$ to $\$ 800 / \mathrm{kW}$. The gross heat rate for these turbines is said to be $5885 \mathrm{Btu} / \mathrm{kWh}$ or $6208 \mathrm{~kJ} / \mathrm{kWh}$. These $60-\mathrm{Hz}$ units will be manufactured in the U.S. and are claimed to offer nearly flat power outputs down to $40 \%$ of rated capacity. Turbine $\mathrm{NO}_{\mathrm{x}}$ production is expected to be less than $25 \mathrm{ppmv}$. Highperformance, low- $\mathrm{NO}_{\mathrm{x}}$ turbines are generally available down to ratings of $50 \mathrm{MW}$.

For substation applications down to about $10 \mathrm{MW}$, low- $\mathrm{NO}_{\mathrm{x}}$ and highperformance turbines are also expected to offer serious competition to FC-system commercialization. As the result, a preferred operating niche from a few tens of $\mathrm{kW}$ to about $10 \mathrm{MW}$ appears to describe the early market-entry range for all types of FC systems.

There remains a very important advantage for all FC systems. Whereas current turbines produce a few tens to perhaps $50 \mathrm{ppm}$ of $\mathrm{NO}_{\mathrm{x}}$ and advanced turbines may ultimately produce less than $10 \mathrm{ppm}$ of $\mathrm{NO}_{\mathrm{x}}$, there is no possibility that turbines will ever compete with $\mathrm{FC}$ systems in environments where $\mathrm{NO}_{\mathrm{x}}$-emission limits are set below 1 ppm. For these potentially important applications, the use of FC systems may be mandated, even if their costs exceed those of "clean" competing turbine systems.

\section{IV-2. Estimations of Market Size}

Defining the market for FC systems has self-evident problems and is not likely to be more accurate than, for example, a definition of the market for microprocessors given in 1975. Nevertheless, even the present limited perspective allows some useful summary remarks of which the most important is that there is no single market for FC systems and

\footnotetext{
1 H. U. Frutschi, "Advanced Cycle System with New GT 24 and GT26 Gas Turbines - A Historical Background," ABB Review, No. 1 (1994). An early test of these turbines for repowering of a coal plant is currently being implemented in New Jersey.
} 
no single primary identifiable customer for FC-system applications. As already noted, although the electric and gas utilities are expected to play significant roles, they have no exclusive franchise on the technology and represent only one group of many potential customers.

FC systems are likely to enter many different types of niche markets, each with different entry hurdles and long-term viability. It is not unlikely that different types of FC systems will ultimately dominate different market sectors, perhaps PEMFCs at the smallest scale and the high-temperature fuel cells at the largest scale, with PAFCs competing. at both ends of the spectrum.

Each market sector is characterized by its own set of economic hurdles for commercialization because the relative value of power-conversion technology in each market sector depends on the sector utility. At the large end of the power spectrum (i.e. repowering of generating stations), FC systems must compete against alternative largescale technologies for the commodity value of delivered electricity, unless special circumstances dictate special values for the environmental cleanliness of the FC systems or for exceptional quality and reliability of delivered power. This market will involve both private firms and traditional electric utilities.

A market that has been the exclusive domain of electric utilities is often referred to as offering distributed resources. Although FC technology is only one of several developing entries, it is expected to play an important role in maximizing the assets of utility systems. Substation equipment, which is very capital-intensive, must frequently be upgraded to meet peak demand. In many systems, peak demand occurs only about $10 \%$ of the time, i.e. many substation assets are underutilized most of the time. Placement of medium- to large-size FC systems at these substations will mitigate the need to expend new capital for transmission upgrades and allow maximization of the utility of the 
existing investments. Furthermore, the locally-delivered power is expected to be relatively more reliable without incurring transmission-line losses.

In other applications (e.g., power delivery for emergency use in hospitals, power production at remote locations not connected to a central grid, transportation applications, grid-connected power-quality systems, etc.), the value of the service delivered by FCsystems may far exceed the normal costs of delivered electricity and customers might be willing to pay a premium for such service. Utilities, as well as private entities, are likely to offer such FC-power services.

In summary, the market sales price for FC systems ranges from commodity values in existing markets to very high values where there are no low-cost competing technologies and the only alternative technologies are represented by high-cost photovoltaic or other renewable entries. There are potential high-value markets including, for example, telecommunications requiring remote power sources for specialty electronics needed to operate an optical fiber system. FC systems have important features such as DC outputs that are not characteristics of normal, large-scale generating equipment. It will take time to learn how to take advantage of these special features of FC systems and, when the full potential is well understood, there will no doubt be new and as yet unforeseen application areas.

\section{IV-3. External Drivers in Commercialization}

As noted, there are many market niches where FC systems will become competitive early, even though the actual cost of FC commodity power will be high relative to that available from other technologies. The following are scenarios that may accelerate or slow FC commercialization:

(i) Tightening of environmental standards - Many states, most notably California, have enacted very stringent air-quality requirements, and these regulations continue to 
evolve. FC systems may become the only allowable energy supply in some areas, which will speed economic viability. In addition, there is the strong likelihood that some level of regulation will evolve to limit or shield the public from electromagnetic field (EMF) radiation. Transmission lines are already becoming increasingly difficult if not impossible to construct in many areas of the country, in part because of EMF concerns. Even terminal distribution lines may raise concerns. Thus, any power source that can serve new loads without new wires may prove to be invaluable.

(ii) Deregulation of the power market - There now exists in the US a robust wholesale power market in which utilities, independent producers and broker/marketers participate. The creation of a competitive market has reduced the cost of wholesale

power to those who can access it. If access to this market increases as the result of shopping by large traditional customers, it is theoretically possible for the regional cost of energy to reflect blended costs. High-cost areas that are most ripe for FC-systems sales might then have access to much lower market prices, which will slow the economic viability of FC units. On the other hand, such a market is also likely to develop some price volatility and offer a generally less reliable product. FC systems could play a role in providing energy security and reliability to customers who must value these features in their energy services.

\section{IV-4. Measures to Accelerate Market Penetration}

There are two completely different types of approaches to facilitating FC-system commercialization. Market sales may be achieved by employing market pull or market push.

Market pull is based on the use of incentives in the market place to serve as catalysts in creating and sustaining demands. Examples of this approach include legislative measures to pay special bonuses for low pollutant emissions or for the absence 
of long high-power transmission lines or for electricity generation without offensive noise levels. Market pull may be exerted by requirements for specified minimal levels of FCsystems use. Market push generally involves direct subsidies for research, development, demonstration, market entry, and commercial sales. Its use should be limited but it is by no means restricted to federal agencies. Market push may be provided by FC-system manufacturers, by FC-system users, by state and local agencies, by industry consortia, and even by private foundations. It is, of course, evident that a combination of market push and market pull will be more effective than either procedure alone in implementing early transition to commercial success. Generally, market-pull incentives should be applied to those market niches that are closest to economic viability and market push to those technologies that are relatively less well developed in addressing the needs of a particular market.

A desirable distribution of funding sources for effective market-push implementation falls beyond the scope of our studies. Suffice it to say that all potentially benefiting parties (including the public at large) who will ultimately profit from commercial success of the new technologies are proper participants in providing subsidies for market-push entries.

\section{IV-5. Allocation of Funds for Commercialization through Market Push}

While it is too early to make final choices concerning competing FC-stack technologies, it is obvious that the requirements for commercialization are greatly different depending on development status. IFC-ONSI requires support for large-scale sales, ERC and MCP require first subsidies for large-scale demonstrations and then for commercial sales, Westinghouse requires sales of large-scale units. All of these developers require support for product-improvement $R \& D$, as do the developers of PEMFC and planar SOFC systems. 
As stated in the previous Sec. $\Gamma$ V -4 , this Working Group has not attempted to define a desirable distribution of funding sources to meet commercialization requirements. Market push must receive much greater emphasis over the near term than market pull, although both are useful. With few exceptions, all customer groups and particularly utilities continue to see FC-system prices at much higher levels than the market clearing price, regardless of the market niche that is addressed or the value-added services that are included. As improvements in technology occur and production and volume increase, market pull will ultimately become the most important commercialization driver. It is the view of this Working Group that it is premature to look now primarily to the customers in efforts to commercialize FC systems.

A self-explanatory schematic summary of how we view the transition to commercial sales is given in Fig. IV-1 without dates and sales volumes, which will strongly depend on the extent to which market-pull and market-push measures are implemented. 


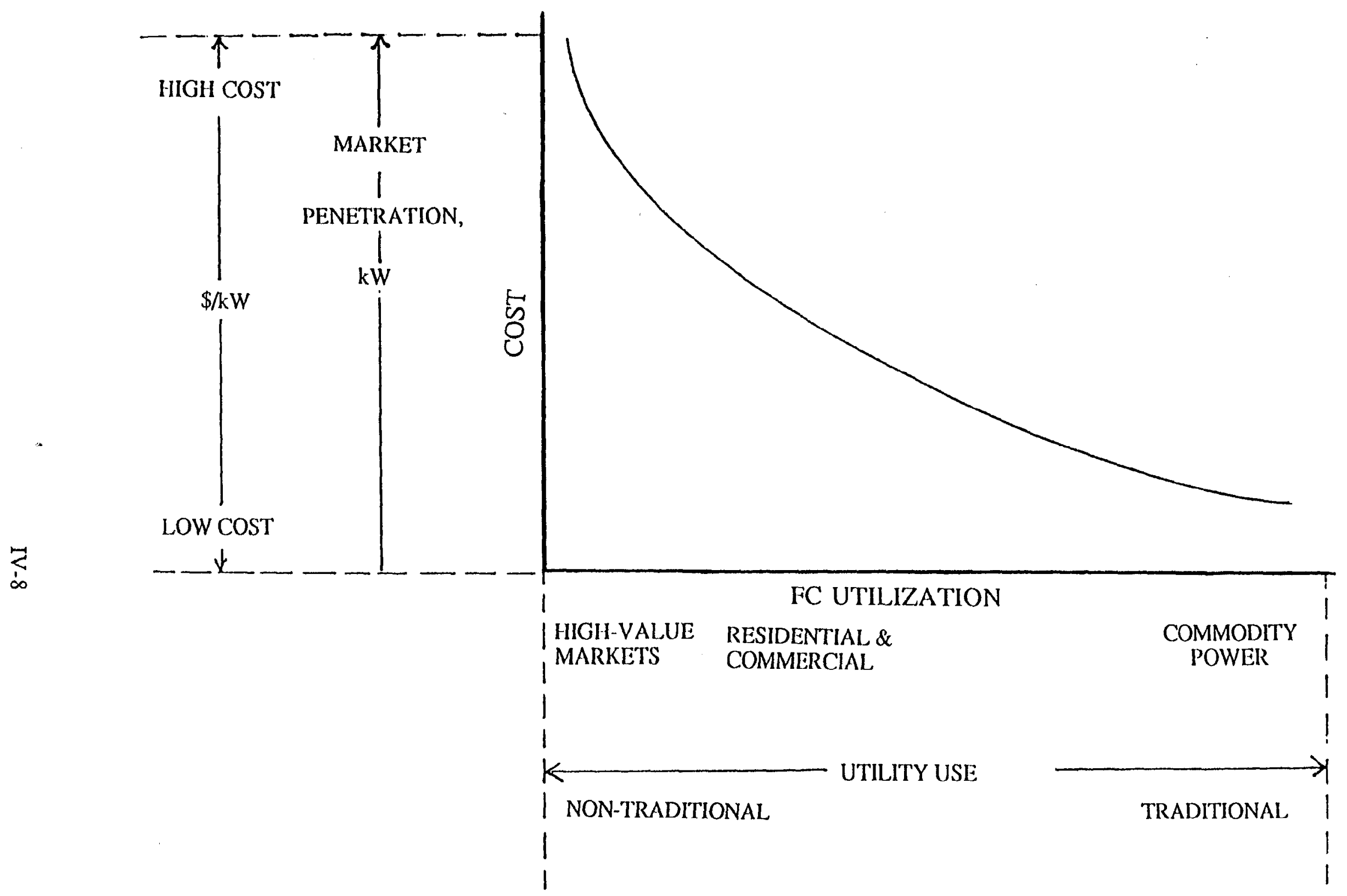

Fig. IV-1. Schematic of the cost vs utilization function for FC-system commercialization. 


\section{MANUFACTURERS' PERSPECTIVES ON FC-SYSTEM \\ COMMERCIALIZATION}

\section{V-1. Overview}

This chapter contains summaries of the commercialization programs of participating fuel-cell manufacturers listed in alphabetical order and printed as submitted without comments, modifications or editorial changes. The contents of these summaries have not been reviewed, approved or disapproved by the AFC2WG and are the sole responsibility of identified authors. Contributions are included from AlliedSignal, Ballard, CeramateiSOFCo, Dow/Ballard, ERC, IFC, MCP, Westinghouse, and Ziek. 



\section{V-2. AlliedSignal Recommendations for a Major New Initiative to Develop Monolithic or Planar SOFC Technology for American Industryt \\ INTRODUCTION}

AlliedSignal strongly believes that commercialization of fuel-cell systems is in the best interest of national competitiveness in the power production market. Fuel-cellbased electric generators have the potential to displace high-temperature combustion systems in significant segments of the stationary and mobile power markets. The advantages of fuel cells include:

(a) Fuel cell systems are environmentally benign, producing levels of regulated pollutants far below control levels.

(b) Fuel cell systems will operate at higher etiiciencies than high-temperature combustion systems, potentially reducing the cost of electricity, reducing carbon-dioxide emissions, and preserving fuel reserves.

(c) Fuel cell systems are ideal for on-site distributed power applications. This will result in cost savings in transmission and distribution of electricity.

The pace of international development in fuel cells is accelerating. In many areas the Japanese and European manufacturers have access to significantly greater financial resources than their American counterparts. Unless this situation is rectified, America may find itself surpassed and in a nonccmpetitive position.

AlliedSignal thin-iilm electrolyte solid oxide fuel cell (SOFC) technology has important potential advantages over competing technologies that make it an attractive candidate for the on-site distributed power market. Power generators based on this thin-film electrolyte technology will have important advantages in terms of compactness, operation at lower temperatures than competing SOFC $t \in c h n o l o g i e s$, and operation at high efficiencies.

We strongly encourage the DOE and other governmental agencies to launch an ambitious initiative to commercialize fuel cells, making development of the thin-illm electrolyte SOFC an important part of the overall commercialization initiative.

For its part, AlliedSignal is strongly committed to the commercialization of fuel cells for stationary power, military, and transportation applications. We are developing both SOFC and proton exchange membrane (PEM) fuel cells. In so doing AlliedSignal is capitalizing on its synergistic capabilities for developing state-of-the-art materials technologies at its Research and Technology Laboratories and compact, lightweight systems at its aerospace manufacturing faciities.

\section{IMPETUS FOR DEVELOPMENT OF MONOLITHIC OR PLANAR SOFC TECHNOLOGY}

The impetus for development of the monolithic or planer SOFC technologies is principally its potential for lower costs and improved periormance. AlliedSignal's planar and monolithic approaches utilize the inexpensive tape calendering fabrication technology. Also, the higher power density achievable leads to significant reductions in the quantity of material required to fabricate a stack, leading to additional cost savings.

† Submitled by Linus B. Buss. 
AlliedSignal solid oxide fuel cells based on the company's thin-film electrolyte tape calendered technology have demonstrated higher power density than any other known fuel cell. Power density in individual cells approaches $1 \mathrm{w} / \mathrm{sq} \mathrm{cm}$ at $1000^{\circ} \mathrm{C}$ and exceed $600 \mathrm{mw} / \mathrm{sq} \mathrm{cm}$ at $800^{\circ} \mathrm{C}$. With its inherent compactness, this translates into stack power densities on the order of $100 \mathrm{kw} / \mathrm{cu} \mathrm{ft}$, the most compact of all known fuel cells. The cell fabrication process is robust and scalable, with nearly 100 percent yield achieved even in large $20-\mathrm{cm}$-by-20-cm cells.

The excellent performance of this technology at relatively low temperatures will ease the difficulty of development of auxiliary technologies such as sealants, greatly expand the spectrum of available stack structural elements, and may lead to lower-cost balance-of-plant equipment, reducing overall system capital costs.

Additionally, in nonsealed SOFC systems where the fuel and oxidant effluent streams are not separated, intrinsic limits exist on the maximum etiiciency achievable. Since the exit gases are not separated from each other, the conventional approach has been to simply combust the mixture and use the heat in a bottoming cycle. For this reason, the high-efificiency characteristic of fuel cells is diminished since a significant portion of the fuel is combusted rather than electrochemically reacted. The combustion process limits and lowers, via the limits of Carnot efficiency, the total system efficiency. Clearly, a highly efficient system is one in which the bulk of the fuel is reacted electrochemically in the fuel cell at high-voltage efficiencies with a minimal amount of fuel combusted (per pass).

An improvement in system performance can be made if the fuel and oxidant effluent gases are kept separated, as in the case for AlliedSignal planar and monolithic solid oxide fuel cells. In these fuel cell designs, the fuel and oxidant streams do not combine after exiting the fuel cell stack. Hence, the fuel effluent can be recycled into the fuel cell inlet to maintain hydrogen concentrations and to achieve high fuel utilization in the fuel cell system. Furthermore, by operating the fuel cell at high cell voltages, the fuel cell efilciency will be high. Extensive fuel cell system analyses conducted at AlliedSignal have shown that very high efficiencies can be achieved in such systems.

\section{ALLIEDSIGNAL SOFC TECHNOLOGY BASE AND ITS BENEFITS}

\section{AlliedSignal SOFC Fabrication Approach and Electrochemical Periormance}

AlliedSignal has recently developed a fabrication method to produce ultrathin electrolytes on an anode substrate. The simplicity of the fabrication sequence for a thin-electrolyte is shown in Figure 1.

In this fabrication sequence, a bilayer tape comprising anode and electrolyte tapes is formed by passing the tapes between heated counterrotating cylinders. This bilayer tape is then passed once again through the cylir:ders with an anode tape, forming a bilayer with an electrolyte of reduced thickness. This process is continued until the electrolyte thickness is reduced to less than 10 micrometers. The resulting bilayer is fired, and then a cathode is applied to form the trilayer cell. A fracture suriace of such a cell cross section, shown in Figure 2, shows a dense electrolyte positioned between 


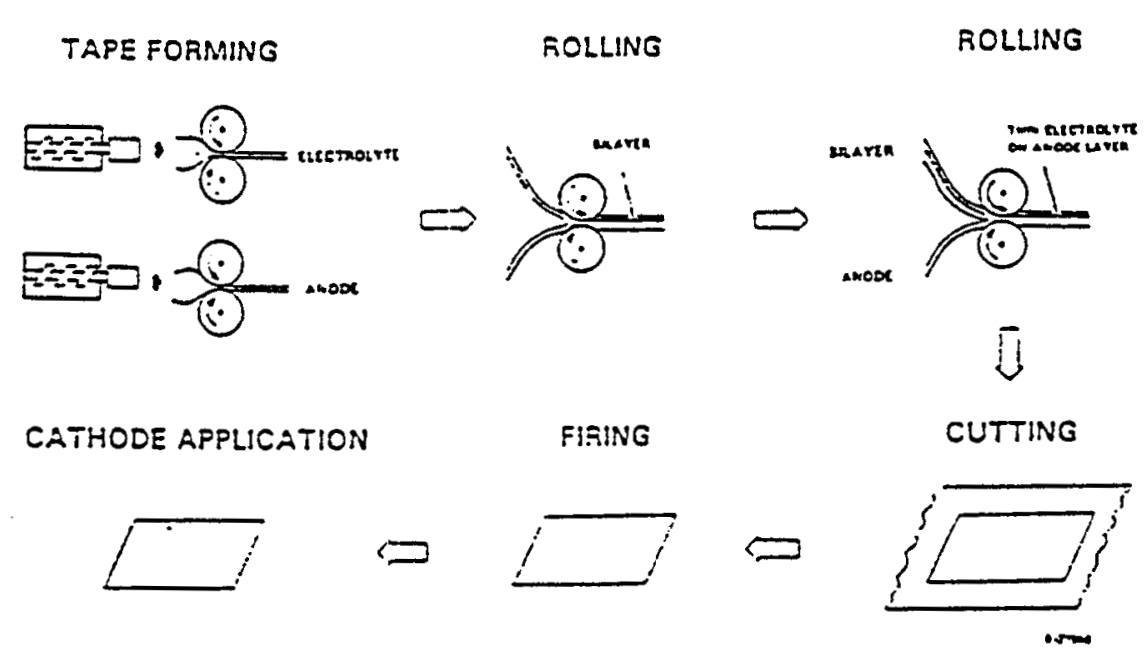

Figure 1. Thin-Electroly:e SOFC Fabrication Sequence

porous anode and cathode. Measured electrochemical performance of a thin-electrolyte cell is shown in Figure 3.

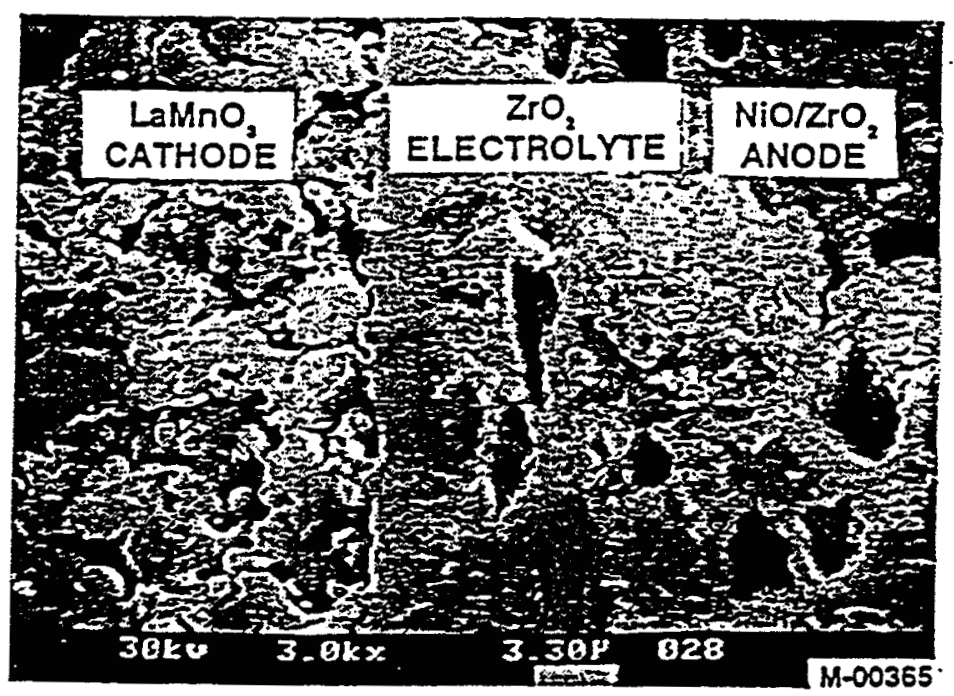

Figure 2. SOFC Fracture Surface

Referring to Figure 3 , at $1000^{\circ} \mathrm{C}$ a power density potential of more than $900 \mathrm{mw} /$ $\mathrm{sq} \mathrm{cm}$ is achieved, while at $800^{\circ} \mathrm{C}$ the power density potential approaches $600 \mathrm{mw} / \mathrm{sq}$ $\mathrm{cm}$. Measurements of open-circuit voltage show values near theoretical, indicating the absence of pinholes or other defects in the electrolyte. Long-duration tests (1000 hr at $800^{\circ} \mathrm{C}$ ) show no detrimental effects caused by material diffusion; this fact was 

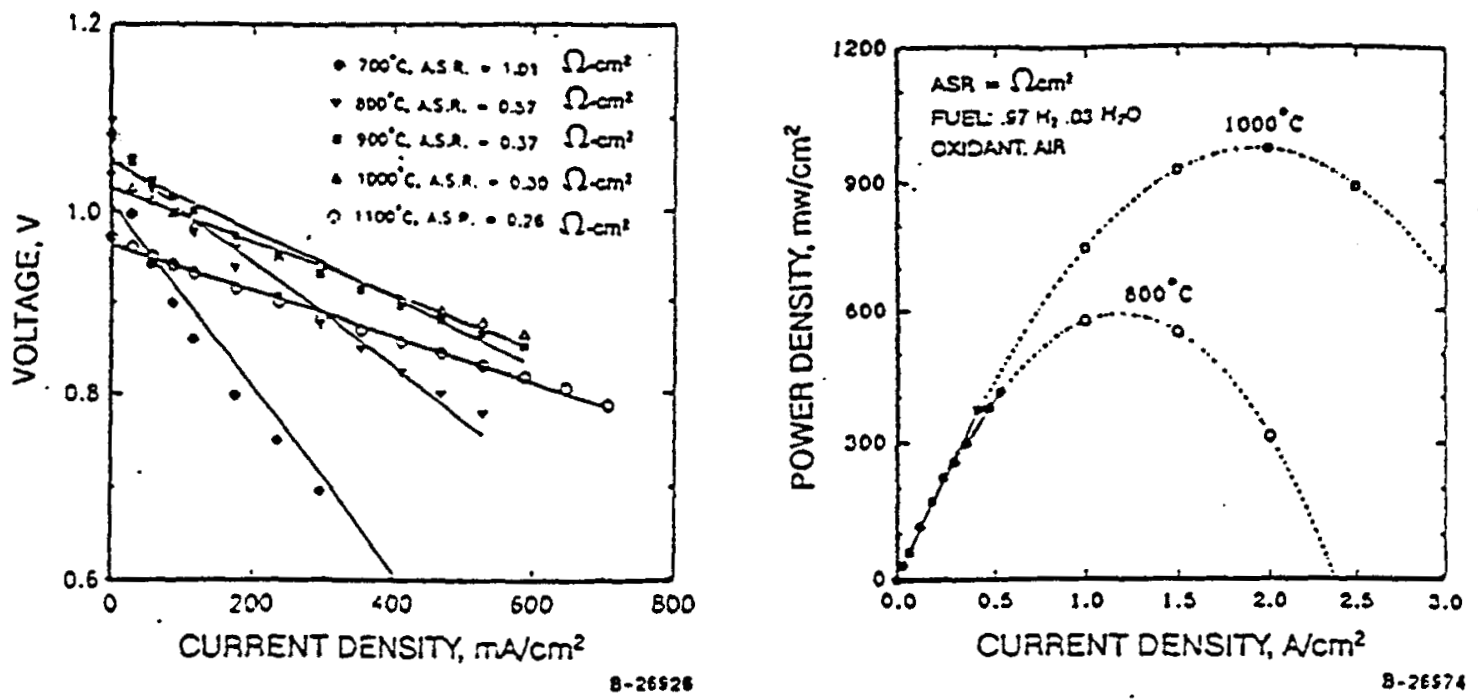

8.26574
8.28116

Figure 3. SOFC Performance Characteristics

confirmed by mapping analysis. Furthermore, the anode/electrolyte layers have proved scalable to footprints in excess of 8 by 8 in. with no evidence of performancecompromising defects.

Potential Cost Considerations

The basic tape-calendering technology is inherently inexpensive, having been developed in the rubber and plastic manufacturing industries. The anticipated fuel cell manufacturing cost is thus primarily driven by the cost of materials involved, in contrast to competing technologies in which thin layers are generally formed through vapor deposition. This approach is inherently more expensive and leads to difficulties achieving acceptable yields and potentials for process scaling.

\section{Comparative Evaluation of Potential SOFC Approaches}

An independent evaluation of the potential periormance characteristics of the leading SOFC configurations has been performed for the Electric Power Research Institute (EPRI). ${ }^{1}$ Evaluation results are summarized in terms of achievable power densities and cell efficiencies, shown in Figures 4 and 5 , respectively. Although the results should be considered qualitative, they show the advantages of the thin-film electrolyte SOFC approach. In fact, as previously shown in Figure 3, further improvements in periormance have been demonstrated by AlliedSignal.

1 Bossel, U. G., "Periormance Potentials of Solid Oxide Fuel Cell Configurations," EPRI TR-101109, October 1992. 
Benefits of Thin-Electrolyte SOFC Systems

The extraordinarily high potertia power density of the ASE thin-electrolyte approach provides the following attributes for SOFC applications.

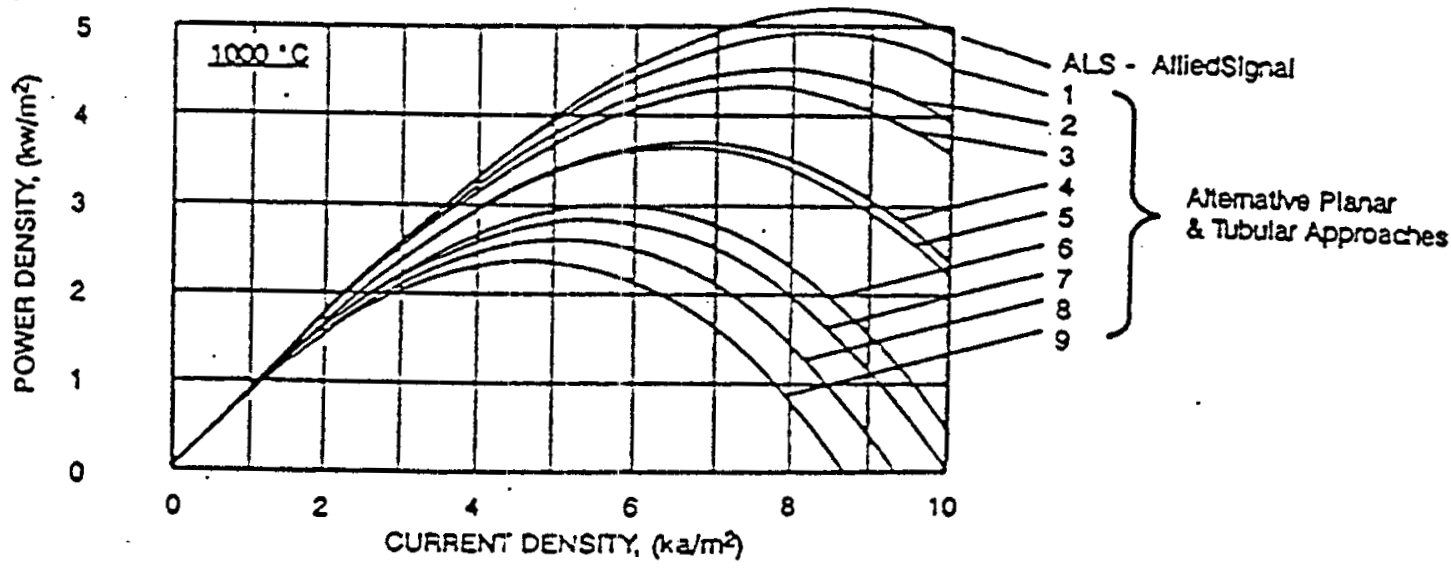

B-28115

Figure 4. Potential Power Density

- Economic considerations-Because the quantity of SOFC material required is substantially reduced and the stack fabrication cost is driven by material cost, coupled with the use of an inexpensive calendering processing technology, a substantial economic advantage is established compared to competitive technologies.

- Reduction in operational temperature - The thin electrolyte offers the advantage of excellent performance at intermediate temperatures. Although this reduction in operating iemperature range has not been iully explored, it is the subject of an ongoing investigation at ASE sponsored by the Gas Research institute (GRI). Recent tests with mixed conducting material interspersed with the baseline anode material show a performance potential of $450 \mathrm{mw} / \mathrm{sq} \mathrm{cm}$ at $700^{\circ} \mathrm{C}$ and $700 \mathrm{mw} / \mathrm{sq} \mathrm{cm}$ at $800^{\circ} \mathrm{C}$. 


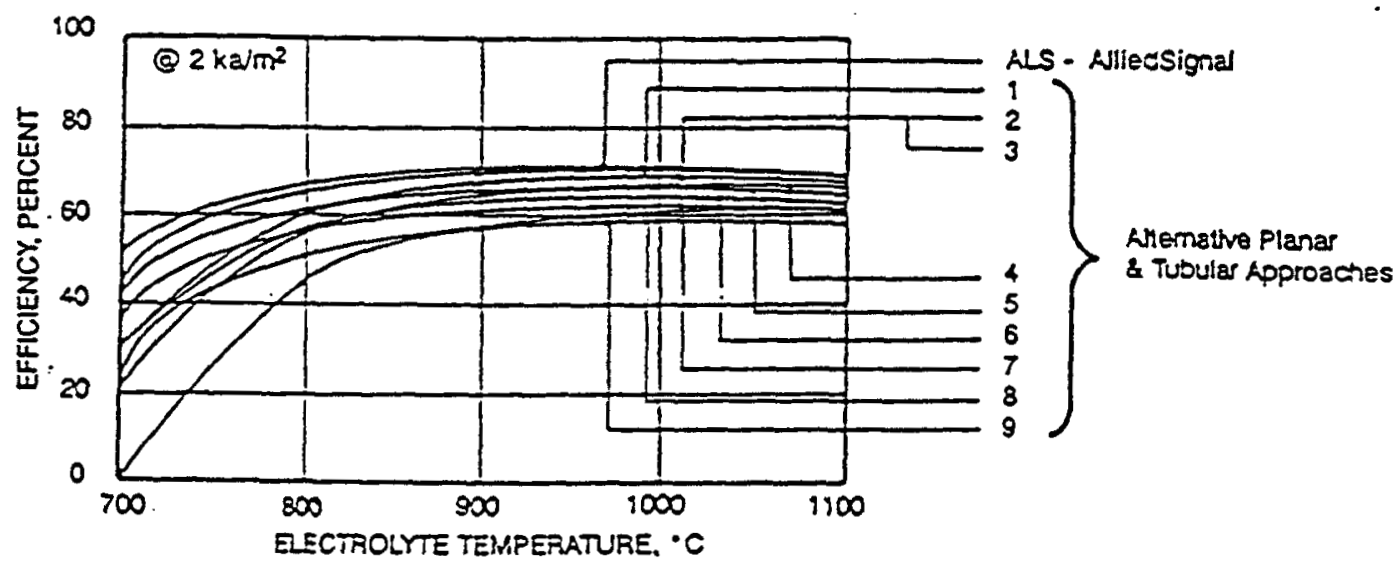

8.28115

Figure 5. Potential Cell Efficiencies

- Increased life potential-Elemental diffusion and changes in cell component morphology are strong functions of operating temperatures and deleterious effects on cell performance caused by these effects can be significantly reduced at lower temperatures. Accordingly, lower operational temperatures will lead to longer cell/stack life capacity, in addition to cost reduction.

- Design flexibility-Potential reduction in operational temperature provides a wider choice of ancillary material in the SOFC. Increased material choice leads to design flexibility such that potential critical paths can be resolved to enhance performance, extend life, and ultimately reduce cost.

TECHNOLOGY CHALLENGES REQUIRED TO ACHIEVE FULL POTENTIAL OF PLANAR OR MONOLITHIC SOFC TECHNOLOGY

The resolution of key technology challenges is required to achieve the full potential of this technology. For both the monolithic and planar approaches, ceramic-toceramic and ceramic-to-metal sealants compatible with operation in high-temperature air and fuel environments are required. Glass and glass-ceramic sealants have shown some promise, but some compositions cause deiormation of the ceramic components of the fuel cell, and thermal expansion matching of these sealants to fuel cell materials has proved difficult.

Although the MSOFC concept has the greatest potential of all known stacking concepts for high power density and low manufacturing costs, further development of a 
suitable interconnect is required. The lanthanum chromite materials developed as the cell-to-cell interconnect expand and weaken in hydrogen leading to stress-induced defects in the stacks.

An alternative approach places the thin-electrolyte cells in a compliant metal structure. This is a new initiative at AlliedSignal, drawing upon our extensive experience in developing and manufacturing hot metal structures for heat exchangers and in gas turbine engines. For this approach to reach its full potential requires metals that resist oxidation at high temperatures in oxygen, have thermal expansion characteristics close to those of the fuel cell, exhibit ductile behavior, can be formed into thin sheets, and retain good strength and mechanical characteristics at high temperature. A search for such materials has begun and many promising candidate materials have been identified. Preliminary evaluations of mechanical and electrical characteristics of these materials are underway. Mechanical designs guiced by the sophisticated stress analysis models available at AlliedSignal are being develcped.

The thin-film electrolyte cells greatly enhance the performance of solid oxide fuel cells at lower temperature $\left(800^{\circ} \mathrm{C}\right.$ or less). The effects of new electrode compositions, perhaps with catalysts added, and new electrolytes on enhancing electrochemical performance at low temperatures should also be evaluated.

For long life, reliability, and multifuel operation, the following should be evaluated:

(a) The efiects of elemental difusion from the electrodes into the thin electrolyte and its dependence on the thickness of the electrolyte and the operating and sintering temperatures of the fuel cell, the effects of the formation of lanthanum zirconate interfacial layers between the cathode and the electrolyte, and other chemical interactions between the fuel cell components.

(b) The stability of the thin electrolyte in long-term operation under various operating conditions (current load, transient conditions, thermal cycling, eic.).

(c) The degree to which the quality of the materials and processes must be controlled.

(d) The development of reliable nondestructive evaluation methods for identifying and eliminating defective components at the earliest possible stages of processing.

(e) The effects of fuel contaminants on SOFC anodes, and the development of alternative, contaminant-resistant anodes.

Finally, comprehensive systems analyses should be underiaken to determine the optimal systems approach for a given market. For large commercial generators, low capital and operating costs are of primary importance. For small distributed power applications, compactness and light weight are important qualities. The effects of lowtemperature operation $\left(600^{\circ}\right.$ io $\left.800^{\circ} \mathrm{C}\right)$ on the performance, reliability, and life of the system, stack, and cell should be evaluated. 
WHAT MUST BE DONE TO ENSURE THAT AMERICA BECOMES THE WORLD LEADER IN NONTUBULAR SOFC TECHNOLOGY

The task of taking a fuel cell from its technological inception, developing it, and bringing it to the marketplace is a major undertaking requiring comprehensive engineering, scientific, manufacturing, and management resources.

Currently, the devejopment of planar and monolithic SOFC technologies is being conducted in a noncohesive manner. What we believe is needed is an effor led by a major manufacturing company with the basic technology and system development capabilities that can also organize, direct, and review the technical support eifort required from universities and high-technology support subcontractors. This structuring will permit the most efficient utilization of resources, reducing development costs and accelerating product development, limited only by the pace for resolving technical challenges.

in parallel with the technology development efforts, the manufacturing company must assess the poteritial markets for the SOFC and determine the characteristics of power systems that will compete successfully in these markets. This will require working closely with the end users as well as packagers and architectural and engineering firms. Once the basic technology and the product requirements are well understood, the drivers for product acceptance, such as capital and operating costs, system weight, and system size, can be determined. These drivers will be translated into system and stack designs, materials, and manufacturing processes which will lead to the best product for the marketplace.

The DOE fuel cell effort is focused on demonstrating molten carbonate and tubular solid oxide fuel cell systems and improving the associated technology. DOE resources allocated to the development of promising new fuel cell technologies, such as planar and monolithic SOFC's, are comparatively miniscule and not commensurate with their promise for significant cost reduction.

Japanese and European manufacturers are focusing on these low-cost alternatives to the phosphoric acid, molten carbonate, and tubular solid oxide fuel cells. These efforts clearly give these foreign manuiacturers a significant advantage over their American counterparts.

The "window of opportunity" for developing low-cost fuel cell systems is rapidly closing. America may soon find itself repeating the recent history of the electronic products industry. While American products were first to the market, the Japanese developed superior products with improved technologies, displacing American products and jobs.

It is important to demonstrate, via government-subsidized projects, the features of ivel cell power generation sysiemis io gain general merket acceptance of iuel ceils. However, it is also necessary to ensure that once a place in the market is established for the fuel cell, that American products are not rapidly displaced by superior products from abroad. 
AlliedSignal proposes that DOE follow a more balanced policy, with funding for all phases of product and technology development, such as:

(a) Research at university and national laboratories

(b) Aggressive development of promising technologies such as planar and monolithic solid oxide fuel cells

(c) Laboratory demonstration of the technologies which prove to be cost competitive

(d) Precommercialization cemonstrations at marketplace sites to gain market acceptance

Much additional funding should be made available to develop more cost competitive fuel cells. As these fuel cells are being developed they should be critically evaluated by the DOE for their economic viability, and should be funded, provided the technology shows strong evidence of being cost competitive in the commercial marketplace. In this manner, fuel cells will more readily gain user acceptance and public support.

\section{Allieo'Signal RECOMMENDATIONS FOR PLANAR SOFC DEVELOPMENT}

AlliedSignal believes that for the relatively modest development costs of approximately 135 million dollars, a planar SOFC product accessing, in various forms, large segments of the distributed commercial power, military generator, and transportation markets can be developed by the end of the decade. Considering the revolutionary nature of this product and the aggressive efforts in this area at Mitsubishi, Siemens, and other large manufacturing firms in Japan and Europe, this is a relatively minor investment to ensure American leadership in this area so vital to our future. 


\section{V-2A. R\&D NEEDS FOR PLANAR SOFC SYSTEMS}

\section{PLANAR SOFC TECHNOLOGIES}

Planar SOFC research and development have received much attention recently. The advantages of planar SOFC's include potentially low manufacturing cost, high power density, and improved performance. Planar SOFC's also offer flexibility in stack designs and multiple fabrication options. Planar SOFC technology is presently at its initial stage of development, and signiiicent R\&D efforts are required to bring the technology toward commercialization.

Planar SOFC's consist primarily of the monolithic and flatplate designs. The monolithic SOFC is the design concept in which thin cell components are configured in a compact corrugated structure. The monolithic design has two versions, the coflow and crossitow versions, and recent development efforis have been concentrated on the crossflow version due to its simpler gas manifolding. The feasibility of the monolithic SOFC has been demonstrated on a laboratory scale. Single cells have been operated to show achievement of theoretical voltage and low interfacial resistances. Multicell stacks have been fabricated and tested. Internal reforming of hydrocarbon fuels, inclucing simulated diesel fuels, has been demonstrated.

The flatplate or planar SOFC consists of cell components configured as thin planar plates. Common plate shapes are rectangular (square) or circular." Flatplate SOFC single cells as large as $400 \mathrm{~cm}^{2}$ have been fabricated and operated under a variety of conditions. Cells have been operated for thousands of hours, and low degradation rates have been achieved. Flatplate SOFC stacks with footprints as large as $225 \mathrm{~cm}^{2}$ and heights as great as 200 cells have been fabricated. Long-term operation (thousands of hours) has also been demonstrated for ilatplate SOFC multicell stacks.

\section{REDUCED-TEMPERATURE SOFC'S}

At present, the critical issues facing planar SOFC technologies are the development of suitable material and cost-effective fabrication processes. These issues relate, in turn, to the $1000^{\circ} \mathrm{C}$ operating temperature of the fuel cell. This high operating temperature imposes stringent processing requirements and limits the choice of cell and ancillary materials. Reducing the operating temperature (to $600^{\circ}$ to $800^{\circ} \mathrm{C}$ ), therefore, is desirable. Efficient operation of the SOFC at $600^{\circ}$ to $800^{\circ} \mathrm{C}$ alleviates the materia! and performance problems while still allowing reforming of hydrocarbon fuels within the cells. The advantages of reduced-temperature operation for the SOFC include wider material choice, longer cell life, reduced thermal stress, improved reliability, and potentially reduced fuel cell cost. These advantages are particularly important for planar SOFC designs. Due to the nature of their fabrication and assembly, planar SOFC's can reacilly incorporate modilications resuiting irom lower operating temperatures. For example, planar SOFC's can incorporate metallic interconnects without major changes in the fabrication process or stack assembly.

The SOFC can be operated efficiently at reduced temperatures by reducing the thickness of the zirconia electrolyte to minimize onmic losses. In this respect, 
development of a suitable fabrication srocess for making thin-film electrolytes is critical. The present conventional approach in fabricating a thin electrolyte film is to use either a deposition or a coating technique (e.g., plasma spraying, chemical vapor deposition, sol-gel coating, etc.). In many cases, deposition and coating techniques involve complex chemistry, require many process steps, and can be dificult to scale up. Recently, a simple and cost-effective process, based on tape calendering, has been shown to be capable of producing high-quality thin-film electrolyte cells of practical sizes. Thin-film electrolyte cells have exhibited excellert performance at reduced temperatures with power density approaching $0.6 \mathrm{w} / \mathrm{cm}^{2}$ at $800^{\circ} \mathrm{C}$. These results demonstrate that reduced-temperature SOFC's can be achieved using practical and cost-effective technologies.

\section{TECHNOLOGY CHALLENGES}

The key issues identified for planar SOFC's are materials, fabrication/manufacturing processes, stacking technology, structural integrity, and quality/defect control.

\subsection{MATERIALS}

One of the technological challenges in developing the monolithic and flat-plate SOFCs is development of suitable materials for the unique requirements of the fuel cell structure and environment. The most important challenge in the material R\&D area at this time is to identify suitable interconnect materials. For reduced-temperature operation, there are needs to develop high-ternperature metals or alloys with desired thermal expansion, oxidation resistance, and chemical compatibility properties. For $1000^{\circ} \mathrm{C}$ operating temperature, the challenge is to develop methods of densifying the interconnect (lanthanum chromite) material without affecting the properties of the other components in the fuel cell structure. The interconnect can be densified under suitable conditions by liquid-phase sintering. However, liquid phases terid to migrate to other parts of the fuel cell. The challenge is to develop a more sinterable material or means of minimizing liquid phase migration during firing. Another important material concern is the fuel cell component stability under operating conditions. The interconnect and anode may change dimensions when exposed to the fuel-reducing environment. Significant dimensional changes can cause degradation in cell performance and mechanical integrity.

\subsection{FABRICATION/MANUFACTURING PROCESSES}

Laboratory-scale fabrication methodologies have been developed to form components for planar SOFC stacks. The challenge is to ensure the reproducibility and reliability of each fabrication step. In this respect, the efiect of various process parameters on the fabrication of fuel cell stacks must be examined to allow correlation of defects with process parameters. Critical process parameters must be icentified so ihat ihese parameters can be controlled within the acceptable values. Fabrication processes must be scaled up to a commercial level. The key issue relates to the size limit on processing. Appropriate cost-effective firing methods must be developed for large-scale and large-quantity production. 


\subsection{STACKING TECHNOLOGY}

Gas manifolding, gas sealing, and current collection are important issues in the development of the stacking technology. Gas manifolding is a key in the development of the planar SOFC stack. The manifolding configuration is determined by the design of the stack and can be either integral or external to the stack. Issues relating to manifold design and manifold material must be addressed. Depending on the design, SOFC's may require seals at the edges of the stack and between the stack and gas manifold's. A suitable sealant must have good wetting to the surfaces being bonded, form gastight seals, be stable with respect to both fuel and oxidant, be electrically insulating, and match the thermal expansion behavior of the cell and manifold materials. Practical current collectors must be developed for monolithic SOFC stacks. The design of the current collector is critical to the success of SOFC systems of practical sizes for power sources. The requirements of the design include minimum resistance losses, minimum heat losses, reliable connection to power buses, reliable bonding to the ceramic structure, and minimum cost of material and fabrication.

\subsection{STRUCTURAL INTEGRITY}

Planar SOFC stacks must have structural integrity during fabrication and must maintain their structural integrity over a variety of operating conditions. The integrity of the fuel cell structure is very much dependent on stress distributions developed within the stack. The challenge is to reduce or minimize these stresses. Stress analysis must be performed to determine the relationship between process parameters and operating conditions. Stress levels must be calculated for different conditions that the fuel cell is expected to experience, including sintering, normal operation temperature gradients, off-design temperature gradients, thermal shock conditions, and mechanical loading during installation, moving, and vibration loading.

\subsection{QUALITY/DEFECT CONTROL}

Defects present in SOFC stacks can cause poor performance and mechanical failure of the fuel cell structure. Defects are introduced during either fabrication or operation. The challenge is to fabricate reproducible SOFC stacks with no, or very few, defects. Defects must be analyzed to rationalize their relative severity and to quantify their role in cell performance and cell structural reliability. Techniques for identifying defects must be identified and applied. Another important issue in this area is quality control of starting materials and process parameters. For example, batch-to-batch variation in starting material characteristics can have significant effect on the reproducibility of stack fabrication.

\section{R\&D NEEDS \\ 4.1 NEAR-TERIM R\&D NEEDS \\ 4.1.1 Material Development}

The application of metals as interconnect materials for planar SOFC's must be evaluated. Development of suitable metals and alloys for reduced-temperature 
applications is recommended. This may involve development of techniques to alleviate problems of thermal expansion mismatch and oxidation. Development of methods to improve the stability of lanthanum chromite interconnect and nickel cermet anode under reducing conditions is necessary. Development of approaches to modify and tailor thermal behavior of cell materials is needed for thermal expansion matching and is critical in reducing or minimizing stresses in the fuel cell. Cost analysis of the impact of replacing ceramic interconnect with metallic is recommended.

\subsubsection{Material Properties}

Information on mechanical and thermal properties of cell components (as a function of temperature, atmosphere, and porosity) is needed for modeling, analysis, and design of monolithic and ilatplate SOFC stacks. Of particular interest are the creep rate, modulus of elasticity, and strength of the cell materials at elevated temperatures.

\subsubsection{Fabrication Processes}

Issues relating to reproducibility of cell component fabrication must be addressed. Procedures and processing conditions must be defined for better dimensional control of fabricated components. The degree to which the quality of the starting materials and processes must be controlled should be evaluated.

\subsubsection{Gas Manifolding and Sealing}

Practical manifolds must be developed to carry gases in and out of the stack. The manifold material and configuration should be evaluated in conjunction with the fuel cell stack material and design. A suitable sealant for the monolithic SOFC is needed. The key to developing such a sealent is the matching of the chemical and thermal properties of the materials involved. Development of methodologies for predicting both interactions between potential sealant ingredients and cell materials and other properties of sealants will accelerate the identification of a suitable sealant.

\subsubsection{Current Collectors}

Development of practical materials and designs for the current collectors is needed for commercial-scale systems. No metals other than platinum and other precious metals can serve as the current collector in air at $1000^{\circ} \mathrm{C}$. However, the current collector can be designed to operate in the fuel environment. Under this condition, many metals and alloys are suitable for service.

\subsubsection{Defect/Quality Control}

Techniques for analyzing defects during processing of cell components should be identified, and acceptance criteria esiablished. Important deiecis can be characterized by pertinent NDE measurements. NDE iechniques can contribute significantly to the assurance of structural reliability based on an ability to detect flaws, allowing identification and elimination of root causes. Of particular interest is the identification of a suitable NDE method for detecting defects such as pin holes and microcracks in micron-thin electrolyte layers. 
SOFC's.

Table 1 lists six specific R\&D areas (in order of priority) recommended for planar

\begin{tabular}{|c|l|}
\hline \multicolumn{2}{|c|}{$\begin{array}{c}\text { TABLE 1 } \\
\text { RECOMMENDED R\&D AREAS }\end{array}$} \\
\hline Priority & \multicolumn{1}{|c|}{ R\&D Area } \\
\hline 1 & $\begin{array}{l}\text { Development and evaluation of suitable } \\
\text { interconnect materials, including metals } \\
\text { for reduced-temperature operation } \\
\text { Cost-effective gas manifold designs and } \\
\text { materials suitable for commercialization } \\
\text { Suitable sealants for edge and manifold } \\
\text { sealing } \\
\text { Scaleup of component fabrication, stack } \\
\text { assembly, and operation } \\
\text { Development of current collection } \\
\text { methods and cost-effective current } \\
\text { collector materials } \\
\text { Development of diagnostic methods } \\
\text { including NDE techniques for quality } \\
\text { control } \\
5\end{array}$ \\
\hline
\end{tabular}

\subsection{LONG-TERM AND FUNDAMENTAL R\&D NEEDS}

\subsubsection{Alternative/lmproved Materials}

Development of more sinterable lanthanum chromite or alternative interconnect materials is recommended as a long-term R\&D project. Alternative electrode materials with better catalytic activity may be required for power density/performance improvement or reduced-temperature operation. Methods for minimizing chemical interactions between adjacent cell components, toughening of cell materials, and development of materials better able to tolerate certain impurities (e.g., sulfur) are other long-term material R\&D areas.

\subsubsection{Improved Fabrication and Processing Methods}

Efforts in this area should focus on developing improved or low-cost processing methods. Evaluation of alternative forming and firing processes to shorten cycle time is recommended. 


\subsubsection{Reaction Mechanisms}

The R\&D need in this area should include a more thorough understanding of interfacial resistance losses at the component interfaces and clarification of the effect of gas composition on electrode performance. Diagnostic methods need to be developed for characterizing cell and stack behavior during operation. Mechanisms of performance degradation during long-term operation should be identified.

\subsubsection{Fundamentals of Ceramic Firing Frocesses}

A fundamental investigation of ceramic firing processes is recommended. A better understanding of the behavior of ceramic components during thermal processing (e.g., binder burnout, sintering) plays a critical role in the effort to improve processing reliability. 



\section{V-3. The Ballard PEM Fuel Cell Commercialization Program*}

\subsection{Introduction and Summary}

Ballard Power Systems Inc. commercialization strategy is to develop, manufacture and market products which provide the Company with clear competitive advantages in cistibuted power generation for stationary utility applications, and in engines for transportation.

Ballard's initial commercial products for these markets will be a 250 kilowatt $(\mathrm{kW})$ natural gas power plant for distributed power generation, and a $275 \mathrm{hp}(205 \mathrm{~kW}$ ) fuel cell engine for urban transit buses. Subsequent products will include stationary power plants from $5 \mathrm{~kW}$ to 1 megawatt (MW) for utilities, and fuel cell er gines for fleet vehicles, personal automobiles, and ships.

Over the past ten years, Ballard has become the world leader in Proton Exchange Membrane (PEM) fuel cell technology. The Company has proven that Ballard Fuel Cells work in real life uses. Ballard is now commercializing the PEM technology. To accompish this PEM fuel cell commercialization, Ballard is working with original equipment manufacturers, power providers, and suppliers of key components to improve froduct performance, to lower costs, to develop manufacturing processes, to produce the products, and to take the products to market.

To achieve the commercialization plan established for the Company, aggressive interin goals and milestones are established by which progress can be measured and prospects assessed. Previous specific goals were to demonstrate prototypes of initial product offerings, establish key strategic alliances, advance the Ballard technology, reduce product costs, broaden the Ballard shareholder base, and gain access to the public financial markets.

During 1994 and 1995, the Company is completing engineering prototypes for initial product offerings. In 1996 and 1997 the Company will complete field testing, obtain orders and establish manufacturing capacity for commercial production and sales.

\footnotetext{
* Subritted by R.B. Fleming.
} 


\subsection{Ballard Fuel Cells}

Ballard Power Systems develops and manufactures fuel cell power systems, which are zero emission "engines" that convert fuel into electricity without combustion. Ballard Fuel Cells have shown superior performance in extensive testing, both in the laboratory and in the field. Building on these results, the Company is converting this technology leadership into market success.

The search for clean, efficient power has challenged utilities, power suppliers, automotive comparies and governments for decades. Based on the critical evaluations of customers, Ballard is the leader in a crucial technology, one which can provide solutions for these difficult problems.

Proton Exchange Membrane (PEM) is one of five fuel cell technology types, each distinguished by the electrolyte. PEM fuel cells use as their electrolyte a polymer membrane. PEM fuel cells are compact and produce a powerful electric current relative to their size. They work at lower operating temperatures, respond more rapidly to variable power demands and start more quickly than most of the other fuel cell types. The Ballard PEM Fuel Cell design is simple in construction, modular in design, can be made from low cost materials and lends itself to volume manufacturing processes. These characteristics make PEM fuel cells the only fuel cell suitable for both distributed stationary power generation and tansportation applications.

The core of the Ballard Fuel Cell consists of two electrodes, the anode and the cathode, separated by a polymer membrane electrolyte. Each of the electrodes is coated on one side with a platinum catalyst. Hydrogen fuel disassociates into free electrons and protons (positive hydrogen jons) in the presence of a platinun catalyst at the anode. The free electrons are conducted in the form of usable electric current through the external circuit. The protons migrate through the membrane electrolyte to the cathode. At the cathode, oxygen from air, electrons from the external circuit and the protons combine to form pure water and heat. 


\subsection{Demonstration Programs}

The Company has been successful in completing several key demonstration programs. Under the Zero Emission Transit Bus Program, Ballard unveiled the world's first fuel cell powerec zero emission transit bus. This accomplishment has proven that Ballard Fuel Cells can power a bus that meets the performance of a diesel transit bus, but without the pollution. This success has led to the commencement of the next phase to build a commercial prototype transit bus with increased passenger capacity and improved range. This second phase is jointly funded by California's South Coast Air Quality Management District, the Government of British Columbia and Ballard.

The Utilities Demonstration Program conducted by Ballard has been successful in developing key technologies for the stationary power plant market. Progress made in 1993 has resulted in a hydrogen fueled power plant to supply power to an industrial facility and a natural gas fueled prototype power plant, both cperational in the first quarter of 1994. The proprietary technology developed under this program will form the foundation for the Company's commercial power plants for stationary applications.

\subsection{Strategic Partnering and Customers}

Key to Ballard commercialization is strategic partnering with original equipment manufacturers and suppliers, with whom the Company is jointly developing products for PEM fuel cell primary markets.

In March 1993, Ballard signed a multi-million dollar collaboration agreement with Daimler-Benz AG, one of the world's most technologically advanced automobile manufacturers, to develop compact, high-power fuel cells for automobiles. Daimler-Benz chose to partner with Ballard after evaluating fuel cells from several suppliers. This program's aggressive targets are being met on schedule, and the collaboration has accelerated Ballard's development of products for the transportation market.

In April 1994, the Daimler-Benz group publicly presented Europe's first velicle to be powered by a PEM fuel cell (from Ballard), suitable for operation under everyday conditions. The test vehicle, known as "NECAR" ("New Electric (ar") with its revolutionary drive system has been on the roads of Germany since 1993.

In July 1993, after several years of working together, Ballard signed a collaboration agreement with The Dow Chemical Company, one of the 
world's largest independent power producers, to jointly develop natural gas fueled power plants for stationary applications. The collaboration agreement sets out the scope, terms and conditions of a joint technology demonstration and market entry plan to accelerate the use of PEM fuel cells. Dow and Ballard will work together on the assembly, production, testing and demonstration of these fuel cell systems.

Initial commercial markets targeted by Dow and Ballard are for PEM fuel cell systems for stationary power plant applications such as distributed power generation for commercial, industrial or residential uses. Commercial markets for PEM fuel cell systems encompass transportation, as well as stand-by, emergency and portable electric power generation applications.

Ballard signed a strategic partnering agreement in March 1994 with Johnson Matthey plc, the world's largest manufacturer of platinum catalyst, which is used in the Ballard Fuel Cells. The objectives of this long-term partnering agreement are cost reduction and performance improvement of the fuel cells.

In parallel, Ballard continues to enhance business relationships with customers, such as General Motors, Mazda, Nissan, Mitsubishi, and Renault/Peugeot, all of which are developing products using the Ballard Fuel Cell, or evaluating the Company's power source for their transportation products. The Company has established relationships with Howaldswerke Deutsche Werft for sea going vessels and with Iwatani for stationary power systems applications. The Company continues to work closely with customers in their evaluation of the Ballard Fuel Cell for incorporation of specific market needs into products. 


\subsection{Research and Product Development}

To build commercial products, Ballard's research and product development focus is in four areas:

- Cost Reduction

- Performance Improvement

- Fuel Processing of Methanol and Natural Gas, and

- Operating life.

Significant advances in all of these areas has been achieved. To reduce cost, Ballard demonstrated $75 \%$ less catalyst in developmental fuel cells and lowered the cost of the Ballard proprietary polymer membrane by $80 \%$ wille improving its performance.

Ballard demonstrated the doubling of power density in fuel cell stacks, to produce twice the power in the same size unit. A significant accomplishment has been the development of a natural gas fuel processor to be used in the prototype stationary utility powe: plant.

For stationary utility applications, the Company developed and tested a high efficiency fuel cell. This fuel cell stack is being integrated into the subscale natural gas power plant being completed in early 1994. The stack has produced over $10 \mathrm{~kW}$ of power at peak load, making it the world's most powerful PEM fuel cell stack.

By the end of 1993, the Company had operated a Ballard Fuel Cell for over 11,000 hours, more than twice the lifetime required of a fuel cell in an automobile.

The Company's product development focus is to build power systems for the primary markets of stationary and transportation applications to meet specific customer needs. In this way Ballard is able to concentrate corporate efforts on the improvement required for timely commercialization.

The key requirements for the two primary markets differ. For stationary power plants the need is for extended life, reliability and efficiency. For transportation applications, the critical concem is improvement in power density, which is the ratio of power output to weightitand to volume. Cost reduction is a common requirement for bott 


\subsection{Intellectual Property}

The goal of Ballard's patent strategy is to preserve its technological competitive edge and maintain freedom of action. The full range of Ballard's intellectual property, including patents, know-how designs, materials, components and systems, represents a unique and valuable set of technology assets.

The Company seeks to patent the key concepts and components which are believed to provide a significant advantage over competitors, and form the basis of a defensible technology position. Patents are also sought on preferred systems and configurations for incorporating fuel cells into various end products. Patents are first obtained in the United States and then elsewhere in the world.

\subsection{Manufacturing}

Ballard's manufacturing and quality assurance programs deliver the products required by customers. Manufacturing engineering is an integral part of the product design process to ensure that high quality products are easier and less expensive to manufacture from the start. This concurrent engineering also reduces the time that it takes the Company to bring new products and improvements into production and to the market. During 1993 product designs introduced the use of lower cost materials, such as plastics, and high volume processes, such as injection molding and stamping. The Ballard manufacturing processes have been reviewed and revised to enable the introduction of automated manufacturing methods beginning in 1994.

\subsection{Financing}

The goal of broadening Ballard's shareholder base and gaining access to public financial markets was achieved in June 1993, when the Company completed its initial public offering, and was listed on The Toronto Stock Exchange. The Company's business plan is to obtain further product development and commercialization funding from strategic partners, government sources, and equity offerings. 


\subsection{Working with Customers}

Ballard's Fuel Cell technology inas attracted the attention of some of the largest companies in the world. These organizations are working with Ballard to incorporate PEM fuel cell technology into practical applications. This growing list of original equipment manufacturers and power suppliers include:

- Daimler-Benz

- Gereral Motors

- Renault/Peugeot

- Howaldswerke Deutsche Werft

- Dow Chemical

- Nissar

- France Telecom

- Aare-Tessin Electric Power Co.

- Mazda

- Mitsubishi

- Idemitsu Kosar

- Iwatari

\author{
Alitos, Germany \\ Autos, U.S.A. \\ Autos, France \\ Marine Vessels, Germany \\ Power Producer, U.S.A. \\ Autos, Japan \\ Standby Power, France \\ Electric Utility, Switzerland \\ Autos, Japan \\ Autos, Power Generation, Japan \\ Fuel Supply, Japan \\ Fuel Supply, Japan
}

For stationary power generation systems, Ballard is working with The Dow Chemical Company to jointly develop and commercialize natural gas fuel cell power plants that produce electricity at the site of the user for powering buildings and equipment. These power systems address the need for environmentally clean and efficient primary power, auxiliary power for peak periods and standby power. By producing power on site, fuel cell power plants reduce the need to build or expand electricity transmission and distribution capacity.

For transportation power, Ballard is working on a number of applications including urban transit buses and automobiles. 


\section{Stationary Power}

Fuel Cells have many uses in stationary power. On-site fuel cell systems can be used for standby electric power, auxiliary power for peak periods and to generate electricity at sites remote from the grid. Fuel cells are suited for commercial, industrial and residential consumers of electricity in developed and developing countries.

Major users of stationary fuel cell systems will include both electric and gas utilities and independent power producers. Gas utilities have shown interest in small, on-site fuel cell power generating systems which will permit the consumer to produce electricity from natural gas, resulting in a considerably increased share by the gas utilities of the total energy market. Worldwide there are already more than 150 stationary fuel cell power plant installations in operation or on order, ranging in power from $5 \mathrm{~kW}$ to $11 \mathrm{MW}$, using a variety of fuel cell technologies.

For distributed stationary utility applications, Ballard Fuel Celis are an attractive alternative to conventional methods of generating electricity because of their:

- higher efficiency than conventional methods of generating electricity, which translates into lower fuel costs;

- longer fuel cell operating life;

- modular design, which offers flexibility to enlarge capacity as electrical demand rises;

- fast startup and immediate response to changes in electrical demand;

- operation on existing hydrocarbon fuels such as natural gas;

- lack of noxious emissions compared to coal and oil fired methods of generating electricity; and

- elimination of the need for electrical transmission and distribution facilities which cause energy loss and pose health risks.

The Company's strategy is to focus on commercialization of stationary power plants in the lower than $1 \mathrm{MW}$ power segment with an initial product offering of a $250 \mathrm{~kW}$ power plant. This size is appropriate for powering an industrial building, a small hospital, a fast food restaurant or a housing subdivision with about 60 homes. Choosing this market entry size linits the Company's technological risk and provides a platform from which aciditional power plant sizes, both larger and smaller, can be introduced. This extends the market applications from $4 \mathrm{~kW}$ to power a single home to over $1 \mathrm{MW}$ for powering industrial plants and commercial buildings.- 


\subsection{Transit Buses}

Fuel cell powered heavy duty venicles are expected to be commercially available before automobiles or vars. This is because they require a lower power to weight ratio than automobiles and they commonly use high pollution diesel engines. Ballard plans to commercialize fuel cell engines for urban transit buses by 1998. Transit buses are anticipated to be the first heavy duty vehicle to use fuel cell er.gines for several reasons. Each diesel bus produces pollution equivalent to 150 automobiles, and because tansit buses are generally operated by public authorities, they must lead by example and respond to the increasing concerns over the pollution caused by their diesel bus fleets. In the United States the Clean Air Act mandates alternative fuel requirements for urban bases, requiring their engines to meet reduced particulate matter emission standards. Ballard expects that public transit authorities will use zero emission transit buses to achieve the requirements in this Act. Zero emission electric buses powered by Ballard Fuel Cells will provide public transit authorities with a practical alternative to replace their existing diesel bus fleets.

Ballard Fuel Cell powered buses are targeted to cost less than a comparable electric trolley bus, even before adding the expensive electrification infrastructure required for electric trolley buses. In North America alone, there are over 60,000 diesel urban transit buses. Ballard Fuel Cells can be retro-fitted into existing buses in addition to being original equipment for the four to five thousand new buses manufactured each year:

Ballard unveiled and operated the world's first fuel cell powered transit bus in March 1993, successfully completing the first of a three-phase program. A $125 \mathrm{hp}(90 \mathrm{~kW})$ Ballard Fuel Cell engine powers the 32-foct bus using compressed hydrogen for fuel. In August 1993 the bus received favorable attention when it was shown in Los Angeles, Sacramento and Vancouver. The bus is planned to be shown in major cities across North America to demonstrate its practical benefits to prospective customers and legislators.

Due to the success of the Phase 1 bus program, Ballard has been able to move directly to the building of a commercial prototype bus in Phase 2, shortening the bus engine commercialization plan by one year and saving over total development costs. The Phase 2 full-size commercial prototype transit bus to be demonstrated in 1995 will have a capacity of 60 passengers and a range of about $2 \stackrel{1}{=0}$ miles. 


\subsection{Automobiles}

Ballard Fuel Cells are well suited for zero emission light duty vehicles as they offer similar driving and refueling characteristics as the internal combustion engine. Ballard is participating in the U.S. Department of Energy (DOE) PEM Fuel Cell Program, led by General Motors (GM). The goal of the DOE/GM program is the development of a full-sized proof-of-concept test vehicle. The first phase of the program was successfully completed in 1993. The second phase, with the objective of showing proof-of-feasibility, is expected to begin in 1994.

Discussions are ongoing for the supply of fuel cells to other auto manufacturers. For the development of the fuel cell powered electric car, Ballard has supplied Daimler-Benz, Mazda, Mitsubishi, Nissan, and Peugeot/Renault with fuel cells for evaluation and development. The Daimler-Benz collaboration agreement is helping to accelerate the development of the Ballard Fuel Cell engine for automobiles.

Until recently, batteries completely dominated the automobile manufacturers research and development efforts to power an electric car. However, industry experts are beginning to challenge the practicality of batteries for electric vehicles. Much of the controversy over Zero Emission Vehicle regulations stems from skepticism about battery technology. It is widely seen as inconvenient (imited range between lengthy recharges), capable only of limited performance (scant power and heavy weight) and costly (limited life).

Fuel cell engines, however, are dramatically different from batteries. Ballard's power systems would operate continuousiy (with rapid refueling) at a level of performance equal to or better than that of the internal combustion engine. The engines would last the life of the car and would cost less than high performance batteries. The view that zero emission vehicles would not interest consumers may change as advances in fuel cell technology bring an affordable, convenient zero emission vehicle closer to reality for production after the year 2000 . 


\subsection{Marine/Military}

Ballard utilizes opporturities in submarine and aerospace projects to advance technology development and commercialization in the Company's primary markets.

Submarines represent a natural market for fuel cells. Nuclear power submarines are expensive and raise environmental issues. Diesel powered submarines are noisy and must periodically surface or snorkel for air. The search for a clean, costeffective, quiet, Air Independent Propulsion (AIP) for submarines has led submarine users and builders to fuel cells. Ballard has been working since 1990 on an AIP program. Phase 3 of the program, is scheduled to begin in 1994 and end in 1996. Ballard is discussing potential projects with a submarine manufacturer.

Sponsored by NASA in the United States and the Canadian Department of National Defense, Ballard is supflying fuel cells for a project to demonstrate a regenerative system for powering a lunar base camp. The system will use photovoltaic parels to produce electricity for the electrolysis of water from which hydrogen and oxygen will be produced. The Ballard Fuel Cell will then use these constituents to produce power and pure water in periods of darkriess. The fuel cells will be delivered in June 1994 and NASA plans to have the test system operational I August 1994 after system integration at NASA's Jet Propulsion Laboratory in Pasadena, California. 


\subsection{Support Activities}

The United States is engaged in global economic competition. Overseas governments in Asia and Europe are providing direct subsidies for commercialization of fuel cells and alternative energy projects. The Japanese are conducting aggressive fuel cell commercialization programs, with the Europeans rapidly expanding their activities.

Ballard recommends that joint federal/industrial sector fuel cell commercialization efforts be expanded by the U.S. federal government.

Steps towards commercialization of products which are recommended include:

- Direct govemment purchasing of fuel cell power plants and transportation vehicles which contain fuel cells.

- Appropriations to utilities which encourage the testing and implementation of fuel cell systems.

- Establishing a chartered bank to invest in industry organized consortia to build fuel cell stationary power plants and transportation systems, with loan guarantees to the corsortia.

- Applying tax incentives of limited duration specific to purchasers of fuel cell systems.

- Implementing the promotion of pre-commercial mass production levels of cellis.

- Establishing a U.S. fuel cell commercialization program that creates a new, high technology industry to contribute to America's energy efficient, environmentally sound future.

- Expanding U.S. funding of fuel cell R\&D programs to complement the commercialization process. 


\section{V-4. The Ceramatec/SOFCo SOFC Power Generation Systems: Development and Commercialization*}

\section{Introduction}

Fuel cells are widely recognized as one of the most promising family of technologies to meet future power generation requirements. Since fuel cells directly convert fuel and an oxidant into electricity through an electrochemical process, they can achieve operating efficiencies approaching $50 \%$, while producing very low levels of pollutants $\left(\mathrm{NO}_{x}, \mathrm{SO}_{x}\right.$, and $\left.\mathrm{CO}_{2}\right)$. Fuel cell systems have few moving parts, which makes them quiet and reliable and amerable to production in standardized modules. Of the various fuel cells under development, Solid Oxide Fuel Cells (SOFCs) are particularly attractive because of their solid state construction (no liquid electrolyte) and ability to be integrated into compact, rugged power systems fueled directly with today's available fossil fuels. A high efficiency, modular and scaleable planar SOFC module, the patented CFn ${ }^{n t}$ design, has been recently verified, which will be the plattorm for MW class SOFC generators. This modular design concept supporis distributed utility power systems matched to local needs or mobile power units. In addition, low specific weight and volume as well as high fuel efficiency afforded by planar SOFCs in the CFn $n^{\text {N" }}$ configuration, suit power systems for commercial and military applications.

To accelerate the development and commercialization of planar SOFC power systems for both military and civilian markets, the Babcock \& Wilcox Company and Ceramatec, Inc. have formed SOFCO, a research and development limiled partinership. Ceramatec is recognized throughout the world as a leader in ionic conducting ceramic materiels and in planar SOFC technology development. B\&W, with its vast experience in power systems engineering, component manufacturing and customer service, has been a leader in power generation equipment for over 125 years. SOFCo combines each company's technical strengths and market presence to form a product development team focused on rapid commercialization of planar SOFC generators. SCFCO has a patented planar SOFC design, the CFn" design, which features a novel manifolding scheme maximizes reliability, efficiency and modularity while minimizing scaleup costs. This multistack $\mathrm{CFn}^{\text {nx }}$ design concept has been verified in a $1.4 \mathrm{~kW}$ module test operated directly on pipeline natural gas. This modular design is being scaled up to a $50 \mathrm{~kW}$ packaged cogeneration demonstration power plant, operating at high efficiencies on natural gas and coal gas. This will be extended to $200 \mathrm{~kW}, 500 \mathrm{~kW}$ and $2 \mathrm{MW}$ power plants in subsequent phases.

\footnotetext{
- Subminted by E. Barringer and A. Khandkar of SOFCO.
} 
SOFCo, as the leading developer of planar SOFC products in the U.S., is pleased to provide information on its technology and commercialization plans. The status of cell, stack and system module periormance are also summarized below. In establishing our plan, two central themes have been identified as critical to developing cost effective products capable of meeting customer needs. First, the technology being developed is driven by the requirements of integrated power systems, rather than the separate development of the fuel cell stacks and balance of plant equipment. Second, we intend to collaborate closely with key customers, both in the development of the technology and in field demonstrations of prototype systems.

\section{CFA ${ }^{\text {MM }}$ Planar SOFC Technology: Features and Benefits}

The principle of SOFC operation is based upon the electrochemical oxidation of hydrocarbon fuels to produce electricity-and heat directly. A solid, ion-conducting ceramic membrane is used to separate fuel gas (hydrogen, natural gas, and other hyorocarbons) from air. At elevated temperatures $\left(800\right.$ to $900^{\circ} \mathrm{C}$ ), oxygen from air is transported through the ceramic membrane, in the form of negatively charged oxygen ions, to the fuel side of the cell. The oxygen then reacts with the fuel gas through a controlled electrochemical reaction to produce electricity, heat and reaction products (water and $\mathrm{CO}_{2}$ ).

Planar SOFC technology offers several benefits over alternative power generation technologies, including high efficiency, low noise and pollutant emissions, high reliability, low maintenance requirements, and compact, modular system designs. These benefits for power generation applications are further described as follows:

- High Energy Conversion Efficiency. Due to the unique non-Carnot cycle process, electrical efficiencies of $-60 \%$ are obtainable with combined thermal and electric efficiencies in excess of $80 \%$. SOFCo's patented CPn ${ }^{\text {TM }}$ design further enhances the system efficiencies by $-4 \%$. These efficiencies are independent of plant size, thus greatly enhancing modularity and plant economics.

- Environmentally Friendly Power Plants. Owing to high system efficiencies of the CFn ${ }^{\text {in }}$ design and the inherent process characteristics of SOFC power plants, the exhaust gases are virtually $\mathrm{SO}_{x}$ and $\mathrm{NO}_{x}$ free and have less than half the $\mathrm{CO}_{2}$ output (per $\mathrm{kW}$ of power) of conventional power plants. Thus, the technology has unsurpassed emission characteristics, capable of meeting the strictest of pollution standards.

- Modularity, Scale-Up. The siate-of-the art features of the CFn ${ }^{\pi x}$ affords scale-up and modularity without sacrificing cost and simplicity. The design minimizes manifold components and piping greatly increasing ruggedness and compactness of power plants. All valves/reactant control equipment are located in cold zones.

- Long and Maintenance Free Life: SOFCs are solid state and have no moving parts, -thus contributing to long and virtually maintenance free life of $>50,000$ hrs. Further, vibration free operation 
permits siting at locations with strict noise, vibraticn and other environmental regulations.

\section{Program Milestones and Technology Status}

The Ceramatec SOFC development program began in 1986, under funding from the Gas Research institute (GRI). During the initial 5 years, efforts were primarily direcied at establishing basic fabrication technologies, development and optimization of key constituent materials, and exploration of various cell and stack designs. With the addition of Norcell (a consortium of Norwegian industrial companies) sponsorship, eftorts shifted toward scaing of cells and stacks and development of kilowatt class SOFC generators fueled by pipeline natural gas. Significant progress has been mace loward developing a low-cost SOFC technology, as illustrated in Figures 1 and 2. Key program achievements include:

Phase I: $\quad$ - Established feasibility of plariar cell fabrication using low-cost ceramic fabrication (1986-87) iechniques

Phase 11: - Established materials, seal and manifold technologies

(1989-91) - Demonstrated stack operation

- 1000 hour endurance tests on stacks

Fhase 1I: - Cells scaled to 4" $\times 4^{\prime \prime}$

(1992-94) Full-height stacks ( $>40$ cells) demonstrated

- Cell endurance targets achieved (20,000 hours)

- Established thermally integratec module design

- Demonstrated $1.4 \mathrm{~kW}$ multi-stack $\mathrm{CFn}^{\text {TM }}$ module with natural gas fuel. It is important to note that demonstration of the $1.4 \mathrm{~kW}$ module in the fall of 1993 represented the largest such demonstration in the world.

Figure 1: Major Milestones and Accomplishments

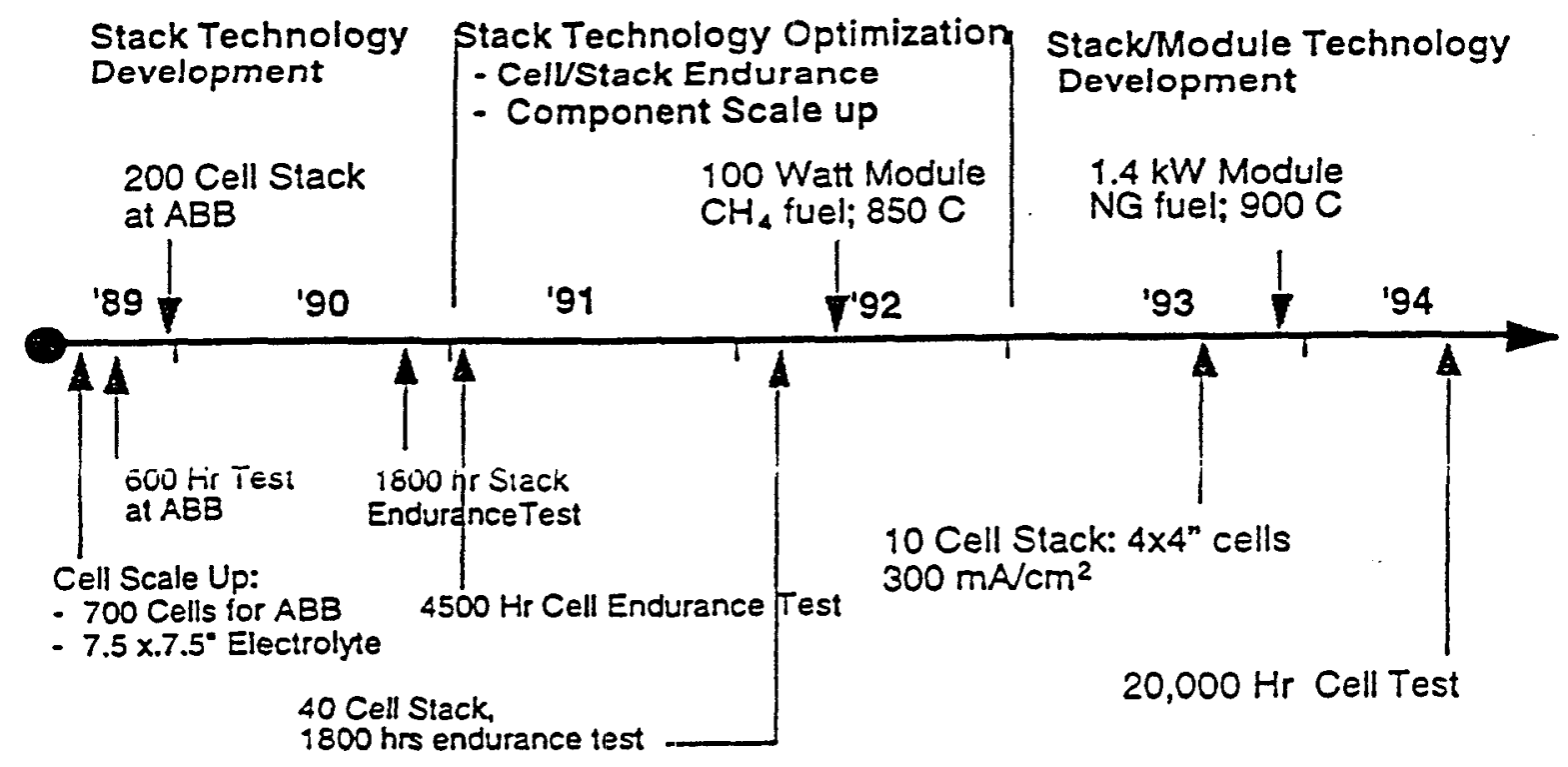


Figure 2: Progress in $C F n^{m}$ Stack/Module Scaleup

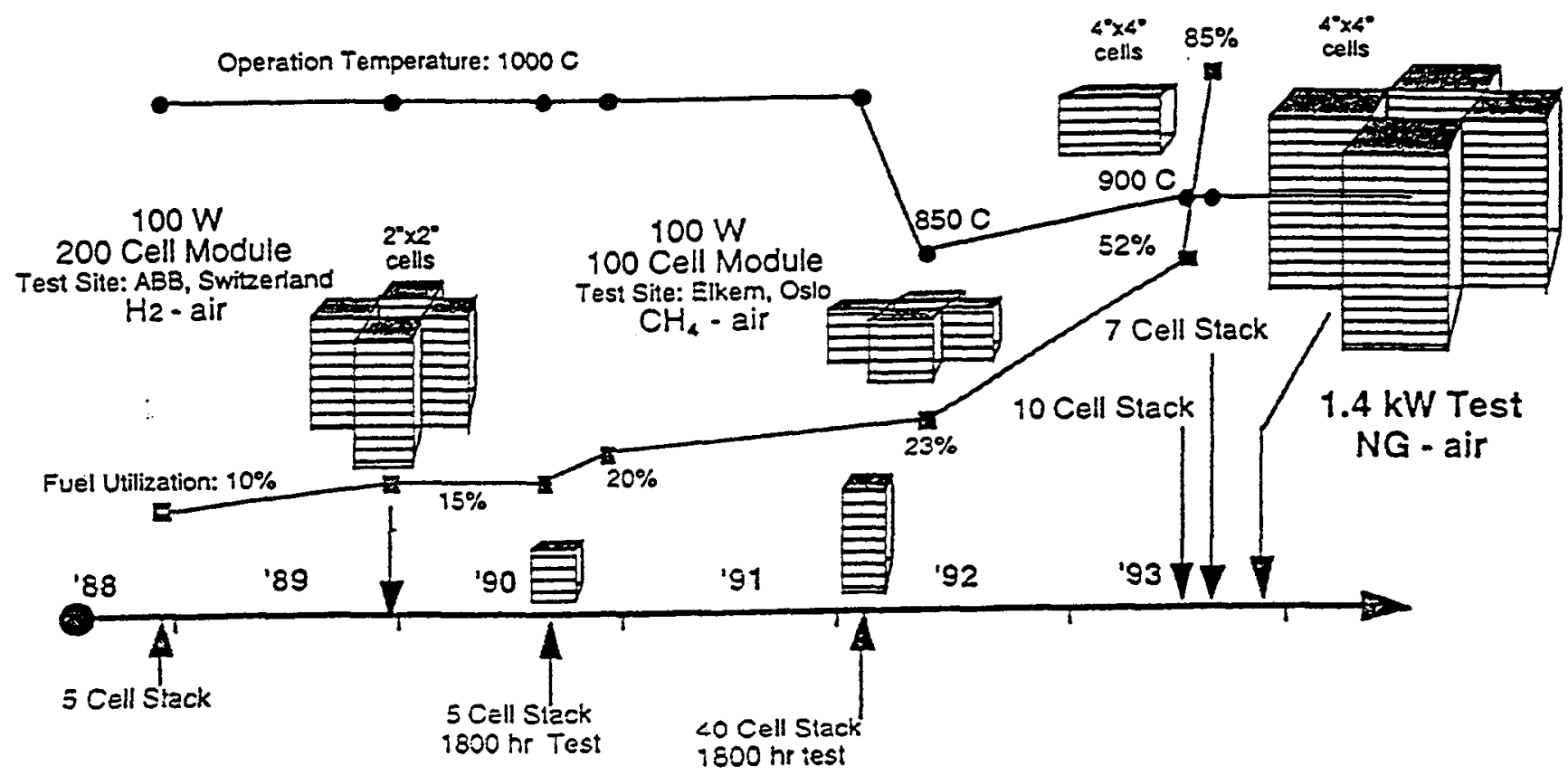

SOFCo has tested a number of cells, stacks and modules for extended periods. State-of-the-art planar cells have been in operation under realistic conditions for $-20,000$ hours with minimal performance degradation as shown in Figure 3. Several demonstrations of the technology have also been made and cells supplied for independent user evaluation for utilities (e.g.. Osaka Gas, British Gas) and power generation companies such as $A B B$ and Sulzer. The 200 cell stack built for and operated at ABB was the largest demonstration of planar SOFC technology in 1989 and the $100 \mathrm{~W}$ direct methane stack test for NorCell in 1992 was the first reported demonstration of a direct methane fueled planar SOFC stack in addition, cells have been supplied to a number of participants such as universities and national labs.
Figure 3: State-of-the Art $G \mathbb{F}^{2} \mathrm{Cell}$ Endurance Test

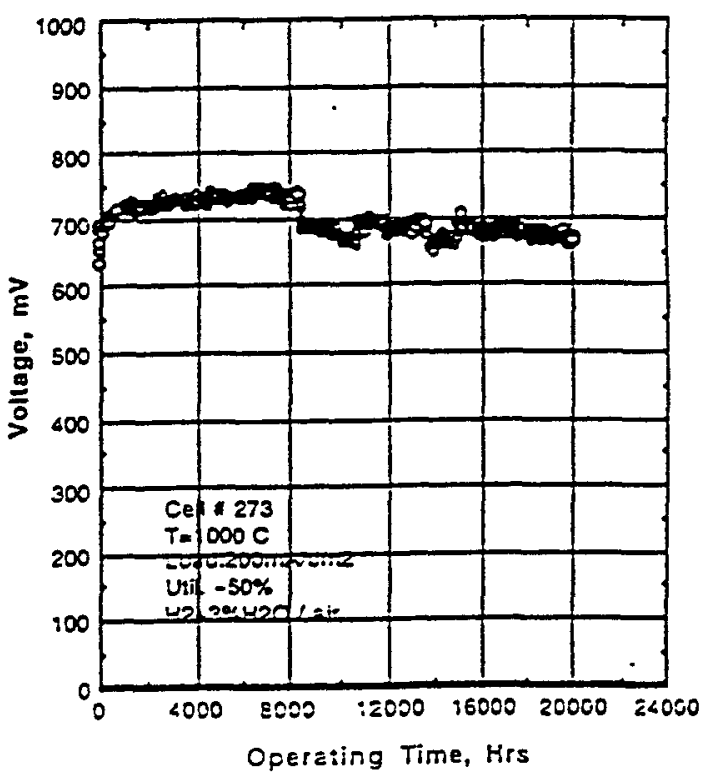




\section{The $\mathrm{CPn}^{\mathrm{N}}$ Design}

The SOFCo $\mathrm{CFn}^{\text {in }}$ concept evolved from recognizing the impact of the balance of plant (BOP) on the economy and efficiency of the total system. The design optimizes the total system and maximizes the efficiency of the system while simultaneously reducing the number of high temperature components peripheral to the stack. The CFnis module consis:s of a multistack arrangement that allows multistage oxidation of the fuel. Efficiency enhancement is accomplished through effective thermal coupling of the stacks and the fuel and air processors. The CFin power system is comprised of planar SOFC slacks, fuel processor components and the BOP equipment. The most significant feature of the CFn's is the Thermally Integrated SOFC Module, which houses the fuel cell stacks, an air heat exchanger, reformer catalyst tubes, and a spent fuel burner. Air, used as the fuel cell oxidant and coolant, is preheated by heat exchange with the stack air exhaust and delivered to the SOFC stacks. The heat exchanger is incorporated into the wall of the module housing. Thermal integration of the processes within the module housing provides for optimal performance and a ccmpact, cost-effective SOFC power system. The fuel processing system is coupled to the stacks within the thermal enclosure accomplishing internal reformation of hydrocarbon fuels. Thermal integration of key processes within the module provides for optimum system performance and a compact, rugged power sysiem. The key to achieving a low-cost, reliable system is the iterative design and manufacturing development of primary components from a systems perspective, rather than developing each component separately and then combining them into a system. To summarize, the SOFCo CFin power system has been successfully demonstrated in a 1.4 kW module. Photographs of this test system are provided in Figures 4 and 5 . The key advantages of this unique design concept are:

\begin{tabular}{|c|c|}
\hline Design Features & Advantages \\
\hline Planar crossilow stacks & $\begin{array}{l}\text { Simple, low cost } \\
\text { ease of automated assembly }\end{array}$ \\
\hline multistage oxidation & $-4 \%$ higher efficiency \\
\hline direct hydrocarbon fuel feed & high system efficiency \\
\hline modular, ease of scale up & $\begin{array}{l}50 \mathrm{~kW} \text { to multi-500 } \mathrm{kW} \text { modules } \\
\text { with } 20 \times 20 \mathrm{~cm} \text { stacks }\end{array}$ \\
\hline $\begin{array}{l}\text { ease of integration into various } \\
\text { applications }\end{array}$ & product design flexibility \\
\hline
\end{tabular}

\section{Commercialization Plan}

The Ceramatec SOFC development team has been very successful in its efforts to establish the basic SOFC technology. In this section, we describe our commercialization strategy and key activities directed at the development and commercialization of SOFC products for our customers. Although we recognize that a significant commitment of resources will be required to achieve low-cost commercial products, we have taken a major step forward in the formation of SOFCo. We are presently in the 
planning stage for development and demonstration of a $50 \mathrm{~kW}$ natural gas fueled power system and a vility demonstration program.

\section{SOFCo - A Winning Combination}

In June of 1994, Babcock \& Wilcox (B\&W), a unit of McDemot Intemational, Inc., and Ceramatec. Inc., a wholly owned subsidiary of Elkem, an Oslo based global materials company, formed SOFCn, a research and development limited partnership. to develop planar solid oxide fuel cell technology. Babcock \& Wiicox has significant capability in power systems engineering, and in advanced materials and component manutacturing. B\&W also has a strong presence in both the military and civilian power generation markets. Ceramatec has significant capability in ceramic component manufacturing and in ionic conducting ceramic materials. They are a recognized leader in the development of planar SOFC technology. The SOFCo venture combines the strengths of each organization to form a world-class team which is committed to the rapid development and commercialization of SOFC power systems.

Figure 4: $\operatorname{CO}^{\text {nd }}$ Power Module

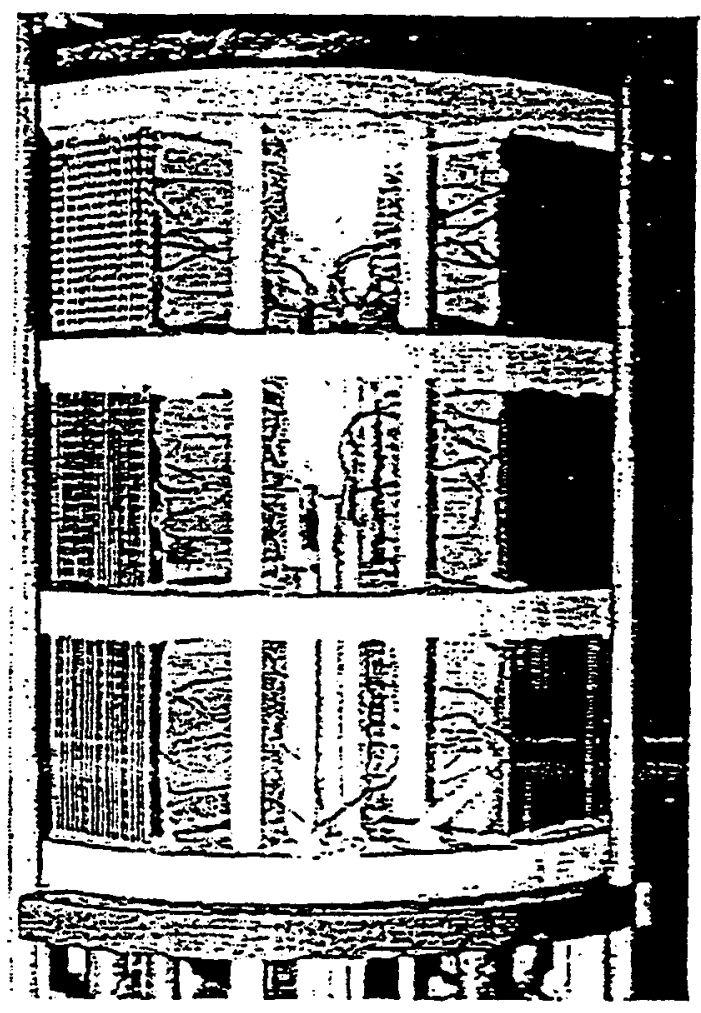

Figure 5: $\mathrm{C}_{\mathrm{F}}^{\mathrm{T}}$ Power System: $1.4 \mathrm{~kW}$ Prototype

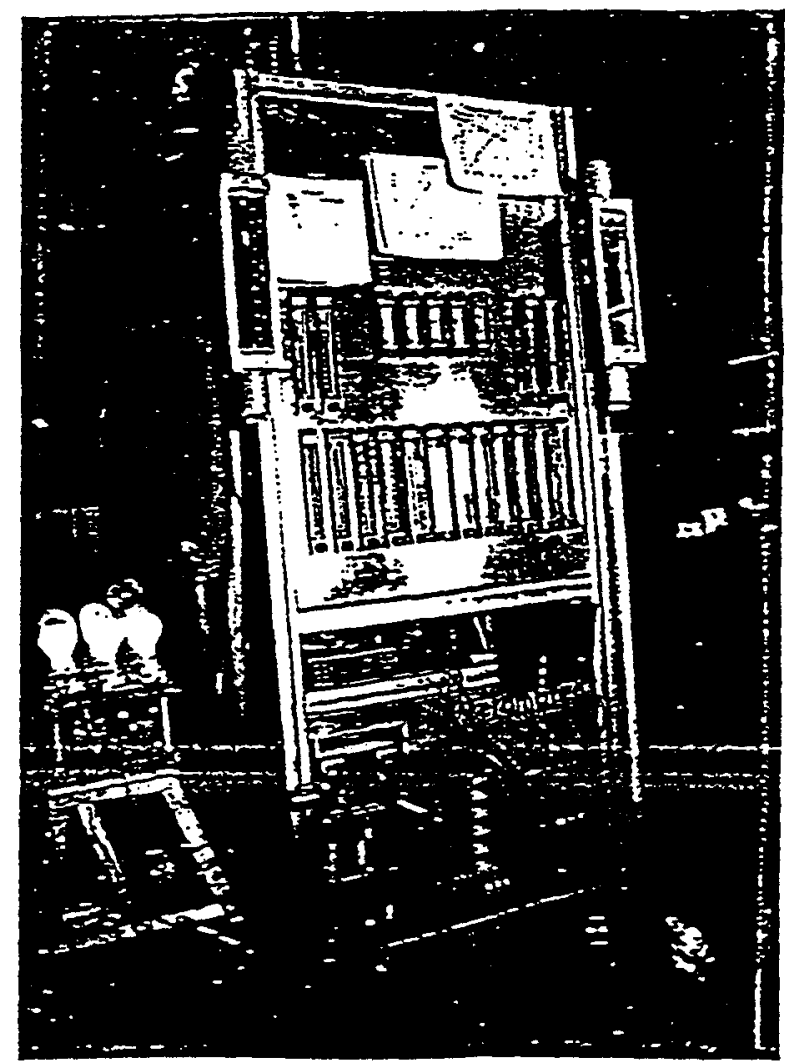




\section{Commercialization Strategy}

SOFCo has established the key strategic elements related to basic technology and product development for targeted markets. In formulating our strategy, a number of factors and guiding principles are being considered and meshed with approaches to develop and refine the iechnology.

- Planar SOFCs have the ability to seve a broad range of applications that are of interest to both military and commercial markets. The CF $n^{T 4}$ planar SOFC design enables production of low cost, high efficiency systems for this broad range of applications. Specific design features can easily be incorporated for optimized systems.

- Market requirements appear to drive development into two slightly divergent directions: 1) compact, mobile power systems, and 2) low-cost stationary power systems. The CFn system is compact (no external reformers) and has the design flexibility that will permit the development and use of products requiring a variety of available fossil fuels.

- Working closely with key customers is essential to the successful development of products which meet market needs. An integrated development team, consisting of SOFCO and key users and suppliers of power generation equipment, will be established with early consideration of manufacturing, process and product design development. In cooperation with strategic parners such as utilities and other customers, system prototypes will be introduced at specified sites to demonstrate the efficiency, serviceability, and environmental benefits of the $\mathrm{CFn}{ }^{\text {Th }}$ power generators. The manufacturability and design will also be verified.

- The cost of developing and commercializing SOFC power systems will be significant. Thus, the internal investments will be leveraged with investments by strategic parners and funding from U.S. Government and other agencies. The present thrust is aimed at resolving sysiem level technical issues.

As stated previously, he fundamental stack/module design has been developed. Current efiorts in Phase 1 of the Commercialization program (see Figure 6) are directed at scaling up of the technology to multi-10 kW modules, establishing operating characteristics of power systems, and development of natural gas and diesel fueled power system for stationary and mobile power applications. This will help establish the basis of the CPn ${ }^{\text {Th}}$ power system. This phase will be followed by a three year program where aggressive product optimization (cost, periormance and design) will be conducted concurrently with evaluation pre-market systems at selected user/supplier sites to gain operational experience and input for product optimization. At present, we plan to offer commercial and military products in the $20-200 \mathrm{~kW}$ range around the year 2000 and larger $200-2000 \mathrm{~kW}$ systems by 2005 . Preliminary studies indicate that the planar SOFC system has the potential to deliver the following product performance characteristics:

- $\mathrm{CF} \mathrm{n}^{\mathrm{T}}$ Power Module: $50.200 \mathrm{kWe}$, grid independent

$>50,000$ Hour Life

$>47 \%$ efficiency, HHV

$-2 \mathrm{kgkW},<1 \mathrm{kNW}$ 
- CPrn Power System: Fuel: Pipeline Natural Gas or Diesel fuel

Start-up: Gas fired Healer

Remote monitored operation

Automatic system controller

Small footprint: $1.5 \mathrm{~m} \times 1 \mathrm{~m} \times 2 \mathrm{~m} / 50 \mathrm{~kW}$ system

$3 m \times 3 m \times 3 m / 200 \mathrm{~kW}$ system

Figure 6: Commercialization Plan

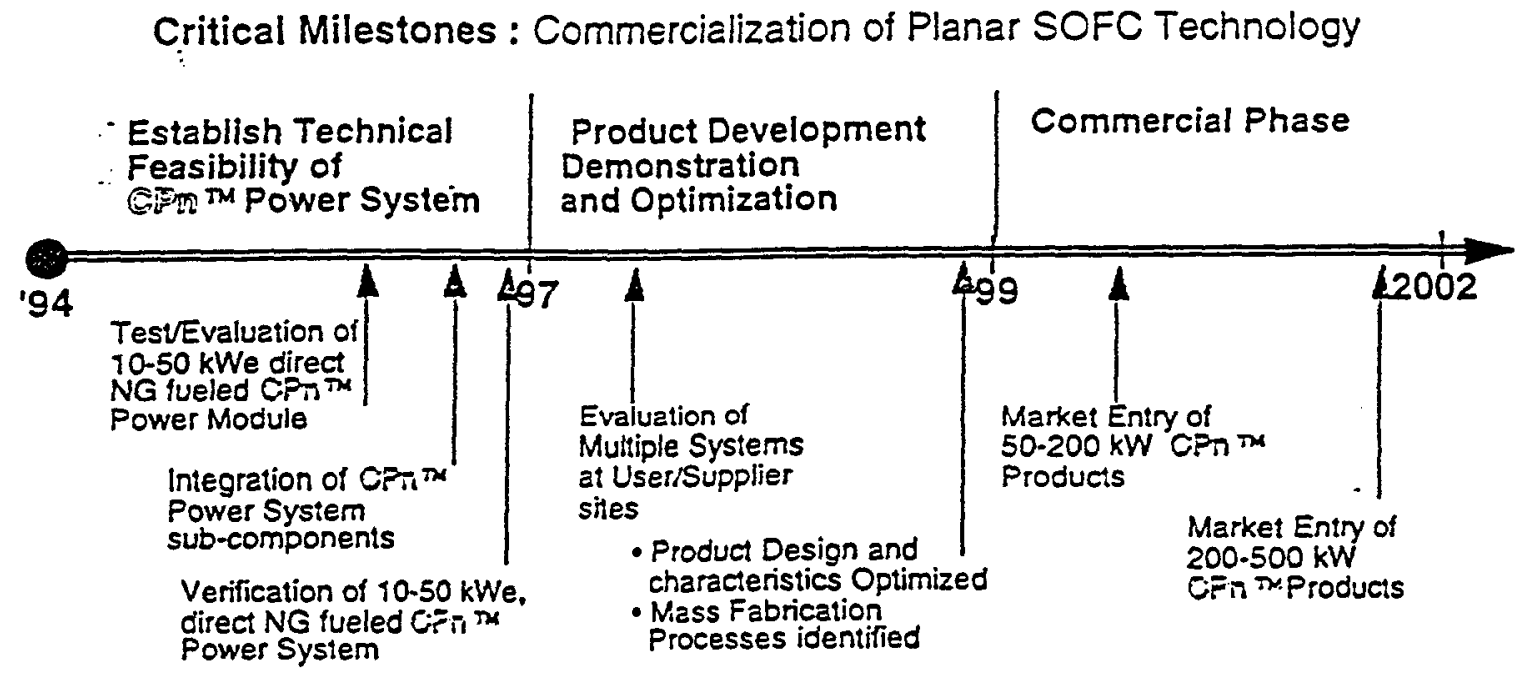

\section{Summary}

Thus, the SOFCo team is committed to the rapid commercialization of planar SOFC technology for a variety of applications including commercial and military power generation. The team leverages the synergies of both B\&W's long and well established experience in power generation systems with Ceramatec's expertise and proven technology in planar SOFCs. The complementary strengths of both the organizations have been pooled to rapidly develop commercially and technically viable products based on the patented CFn ${ }^{\text {TM }}$ planar stack design technology. The SOFCo team will continue to be customer focused and will work closely with users and suppliers of power generation equipment in the development of commercial products. Based on the technical milestones acheieved thus far, SOFCo is contident of meeting both the technical and commercial milestones.

Acknowledgment: The SOFCo team wishes to acknowledge the support and cooperation of the Gas

Research Institute, NorCell, the U.S. Department of Energy, Electric Power Research Institute, Advanced Research Projects Agency, Sulzer Bros., ABB, Osaka Gas Co. and British Gas. 
V-5. The Dow/Ballard PEM Fuel Cell System Development and Commercialization Programs*

\section{Introduction and Sumnary}

The Dow Chemical Company and Ballard Power Systems Inc. have formed a joint collaboration program to develop and commercialize Proton Exchange Membrane (PEM) fuel cell systems for stationary power plant applications. An active development program is now underway, with plans to demonstrate the viability and advantages of PEM technology in stationary power plant applications. Dow and Ballard plan to commercialize a $250 \mathrm{~kW}$ natural gas powered PEM fuel cell sy'stem that provides cost competitive electricity before the turn of the century.

\section{Dow / Ballard}

Dow and Ballard each bring substantial technology and expertise to this collaboration. Dow is a global leacer in the membrane technology used in PEM fuel cells, and provides expertise in electrochemistry, advanced materials technology and chemical processing. Ballard is the world leader in the development and commercialization of PEM fuel cells. Currently, Ballard is the exclusive source of two "proof of concept" power plants. These include the world's first $10 \mathrm{~kW}$ ratural gas powered fuel cell plant, as well as the world's largest - and first - $30 \mathrm{~kW}$ hydrogen fueled PEM stationary power plant. Additionally, Ballard is demonstrating the viability of a $100+\mathrm{kW}$ PEM fuel cell system in motive applications through the use of a transit bus, a Daimler Benz car, and other uses.

\section{Commercial Markets}

Initial commercial markets are for natural gas powered PEM fuel cell systems in stationary power plant applications, such as distributed power generation for commercial, industrial, and residential uses. An active Dow/Ballard demonstration program is underway to prove the viability of this technology. Other potential commercial markets for PEM fuel cell systems include transportation, stand-by, emergency, and portable electric power generation applications.

PEM fuel cell technology is expected to grow through the next century as public concern and government regulation for environmentally clean power generation increases.

\footnotetext{
- Submitted by J. Gunshre.
} 


\section{Berefits of PEM Systems}

All fuel cell systems offer high efficiency, low emissions, quiet operation, heat recovery and modularity. PEM systems will drive improvements in system costs, reliability and footprint.

PEM fuel cell systems use a solid polymer membrane electrolyte. There is no need for any chemical additives other than fuel and water. This offers improved corrosion resistance which simplifies plant construction and reduces the need for frequent stack replacement. Plant overhaul, maintenance, and materials costs can also be reduced.

PEM systems can withstand high-pressure differentials and operate under lower temperatures. This provides the system with easier maintenance.

Because the system does not produce steam, no boiler systems are required. Less material and capital is required to build the plant. Higher cell voltages are possible, resulting in higher power density. With simpler systems and fewer components, PEM power plants can be manufactured at lower costs, and operated more cost-effectively.

Fuel cell technology also generates considerably less emissions than coal or gas turbine fueled power. When you compare pounds per million kilowatt hour of electricity generated, fuel cell emission totals for NOx, CO, NMIHC and $\mathrm{SO}_{2}$ totaled only 45 pounds, versus over 1,000 pounds for gas turbine and over 9,500 pounds for coal. Currently, fuel cell technology far exceeds even the most stringent requirements of the South Coast Air Quality Management District (SCAQMD).

Additionally, PEM can satisfy a broad variety of high-volume power requirements. Unlike other fuel cell technologies, many practical demonstrations of PEM fuel cell systems have been in motive applications. Development in one market benefits commercialization efforts in another. Work in stationary power, for example, will help achieve the kind of system understanding and system cost reductions necessary to make this technology cost competitive in motive applications. 


\section{Economics}

PEM fuel cell system simplicity and reliability allows them to achieve costs of electricity which can be less than those generated by traditional technologies. At an installed cost of $\$ 1,500 / \mathrm{kW}$ and at $40 \%$ fuel efficiency, PEM fuel cell systems are an economic alternative to other forms of power generation. For stationary power applications, PEM fuel systems are a cost competitive option to conventional power generation technology in sizes ranging from $10 \mathrm{~kW}$ to $5 \mathrm{MW}$. Economics are best achieved when the system is used under constant load and operation.

Dow and Ballard see PEM fuel cell technology as capable of making the important step in cost reduction to make this technology viable. The cost reductions will occur because PEM fuel cell technology offers good electrical efficiency and a much simpler design than systems utilizing a liquid electrolyte. As system cost reductions and reliability are demonstrated in stationary applications, PEM fuel cell commercialization in motive applications will be accelerated.

Power Plant Development

Dow and Ballard currently have an active program underway to demonstrate the viability of PEM fuel cell systems in stationary pow'er plant applications.

The complete PEM fuel cell power system being developed by Dow and Ballard includes subsystems for processing natural gas fuel, air, power generation, cooling and control.

After completing a 10kW proof of concept prototype Dow and Ballard are building a $250 \mathrm{~kW}$ class PEM fuel cell stationary power plant. The development of this power plant marks a major advance in the commercial application of PEM fuel cell systems. A single power plant will provide AC electrical power for applications requiring up to $250 \mathrm{~kW}$ of power. These applications include small hospitals, office buildings, and fast food restaurants. Multiple power plants can be combined to provide power for larger applications. 


\section{Utilities Demonstration Program}

A Utilities Demonstration Program is being conducted by Dow and Ballard to bring stationary PEM fuel cell systems to commercialization. The program is organized into three phases and consists of a number of demonstration projects.

- Phase 1 - Proof of Concept

- Phase 2 - Prototype Development

- Phase 3 - Power Plant Field Trials Phase One

For the proof of concept phase, Ballard has developed a $30 \mathrm{~kW}$ hydrogen gas fueled power plant and a $10 \mathrm{~kW}$ natural gas fueled power plant.

The $30 \mathrm{~kW}$ power plant was constructed with commercially available components. This power plant was developed to demonstrate the viability and reliability of the Ballard PEM Fuel Cell in a stationary power application. The $30 \mathrm{~kW}$ power plant operates continuously in an industrial setting. In this environment, it is subjected to a broad range of weather conditions. This power plant is connected to the electrical power grid, and supplies continuous power to the grid.

The $10 \mathrm{~kW}$ plant incorporates significant technological advances. This power plant demonstrates techrologies and system features which will be used in larger systems. It is the sub-scale prototype of the $250 \mathrm{~kW}$ power plant Dow and Ballard are developing for commercialization. This system will enable Dow and Ballard to prepare their manufacturing operations, as well as gather early customer input from field trials. The most significant accomplishments in the development of the $10 \mathrm{~kW}$ power plant is the improved system integration of a PEM stack with a ratural gas fuel processor.

The use of natural gas in the $10 \mathrm{~kW}$ power plant is the world's first successful use of this fuel in a PEM fuel cell power plant. The natural gas reforming system is capable of converting natural gas to hydrogen, and delivering the hydrogen to the fuel cell system upon demand. This reforming system allows the power plant to take advantage of the large, existing infrastructure and supply of relatively inexpensive natural gas.

\section{Phase Iwo}

Next, Dow and Ballard are developing a $250 \mathrm{~kW}$ prototype power plant. This power plant will incorporate technologies and system features originally developed in the $10 \mathrm{~kW}$ prototype as well as several pieces of technology specific to the larger size. The $250 \mathrm{~kW}$ power plant will take advantage of

$$
V-5-4
$$


further advances in these technologies with a cost reduction focus for commercialization.

\section{Phase Three}

In the third phase, Dow and Ballard will conduct field trials of the $250 \mathrm{~kW}$ power plant. Dow and Ballard will work with utility partners to install these systems in their service areas. The locations and specific applications for each of the demonstration systems is being selected by the utility partner to promote the system in the most favorable manner.

The utility partners will test and evaluate the PEM fuel cell power plants. These test and demonstration activities will accelerate further technological advancement of PEM power plants, and accelerate commercialization.

\section{Government Support}

Although Dow and Ballard are currently spending significant resources of their own, the accelerated program outlined above can not be maintained without external support.

Fuel cell power technologies are attractive choices in leveraging investments, because development will have application in both stationary applications (shorter-term) and motive applications (longer-term).

Fuel cell system development has come further with less development investment than any other power generating technology in history. This is specifically true of PEM fuel cell development. Much progress has been made as commercial development gets further accelerated.

PEM fuel cell systems are now on the forefront of both stationary and motive applications. Systems are being successfully demonstrated in both applications. Dow and Ballard will continue to build on this momentum to deliver low emission, reliable, low-cost systems.

To move this program toward commercial reality, Dow and Ballard request that the US government support new programs for PEM fuel cell technology development in stationary power plant applications. 


\section{Commercialization Plan}

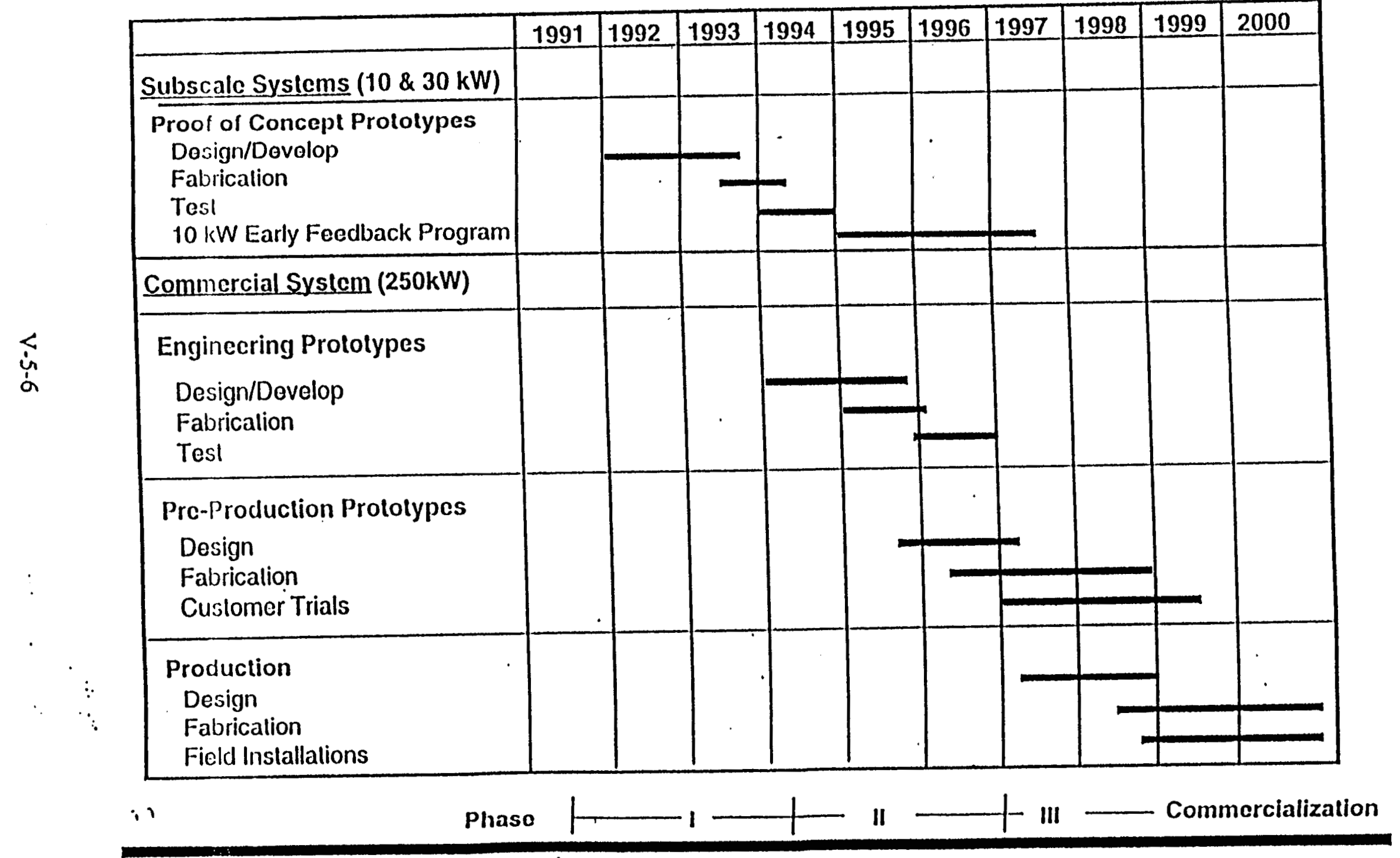


V-6. Energy Research Corporaton Perspectives on Fuel-Cell System

Commercialization"

\section{V-6.1. Introduction}

Energy Research Corporation (ERC) began research activities on fuel cells in the early 1970s. Initially, the emphasis was on alkaline tuel cells fueled by various inorganic hydride compounds from which hydrogen was readily derived. Next, emphasis was placed on methanol-fueled phosphoric acid fuel cells (PAFC). The PAFC activity was expanded to include natural gas fuel for which a large supply and distribution infrastructure is available in the U.S. The alkaline fuel cell activities were dropped because of their dependence on hydrogen, which was, and still is, a costly fuel whose storage is expensive and difficult to manage. In the late seventies, ERC began work on the carbonate fuel cell. Around 1981, carbonate fuel cell research at ERC began to focus on the elimination of the traditional external steam reformer for converting natural gas fuel into a hydrogen-rich gas. ERC refers to this approach as the Direct Fuel Cell.

\section{V-6.2. The Direct Fuel Cell}

Early experiments with the carbonate fuel cell indicated that methane would reform completely if the fuel cell was operated under load. The chemistry associated with the chemical and electrochemical reactions at the anode of the MCFC are symbiotic. At the fuel electrode, hydrogen or carbon monoxide fuel react with carbonate ions from the electrolyte to produce water and carbon dioxide, respectively, and release electrons to the external circuit. As the load or current is increased, fuel is withdrawn from the methane/steam reforming reaction, while steam is released from the anode reaction. These two reactions drive the chemical reaction between methane and water, which results in the formation of more hydrogen and carbon monoxide. Thus, the conventional reforming reaction is driven to completion at temperatures far below the normal equilibrium-type reforming temperatures because the electricity production results in a non-equilibrium reforming reaction. Moreover, the exothermic heat production by the fuel cell due to $i^{2} R$ heating drives the endothermic in situ reforming reaction. This complementary heat and mass transfer thus eliminates the need for the external reformer, heat exchanger equipment and piping required with lower temperature or external reformer type fuel cell systems.

This fuel cell system, termed Direct Fuel Cell (DFC), operates at about 600 to $650^{\circ} \mathrm{C}$ and does not require precious metal catalysts. A substantial portion of the waste heat produced by the fuel cell is removed by the heat-absorbing in sirs reforming reaction, greatly reducing the parasitic power required for cooling. This cooling requirement can be quite high in other systems. The main issue addressed early in the DFC development

\footnotetext{
- Submitled by B.S. Baker and H. Mars.
} 
was the demonstration of the technology at a stack size commensurate with overall thermal self-sufficiency. The other was the long-term efficacy of the internal reforming stack. The first was demonstrated by ERC in the eighties in a series of one ${ }^{1}$ and five ${ }^{2} \mathrm{~kW}$ stack tests. The latter has been demonstrated by ERC and others in cell and stack tests exceeding $10,000^{3,4}$ and $20,000^{4}$ hours, respectively.

Concurrent with the experimental work, ERC, together with the Fluor Corporation, initiated a series of design studies in the early 1980 s on 2 to $10 \mathrm{MW}$ size systems under contracts to EPRI. The 1983 and 1985 siudies $^{5.8}$ concluded that the DFC systems could achieve power plant efficiencies of about $55 \%$ (LHV) for simple cycle designs. Efficiencies approaching $60 \%$ using hydrogen extraction and recycle were identified ${ }^{7}$ in the late 1980 s.

Studies on large natural gas ${ }^{8}$ and coal gas systems ${ }^{\circ}$ employing steam bottoming cycles indicated that respectively $60 \%$ and $53 \%$ efficient systems are feasible. Cost estimates carried out as part of these studies indicated that $2 \mathrm{MW}$ natural gas systems and 200 MW coal gas systems would cost approximately $\$ 1,200 / \mathrm{kW}$ and $\$ 1,800 / \mathrm{kW}$, respectively.

Armed with these results, ERC, in the late 1980s, began to see the basis for a commercial product.

\section{V-6.3. Commercialization}

\section{Independence}

Achieving commercialization requires mastering many disciplines. ERC took its first step in 1988 by becoming an independent private company. Prior to 1988, ERC had been a subsidiary of a series of larger organizations. ERC management believed that an entrepreneurial company focusing on a product that did not compete with related corporate products or large organization corporate culture could be more successiul. To that end, ERC management engineered a corporate leveraged buy out resulting in ERC becoming a privately-owned small business.

\section{A. Manufacturing}

Realizing that it was necessary to initiate a manufacturing capability as an early step in the commercialization process, ERC, in 1989, arranged private financing to build and staff a small-scale manufacturing facility in Torrington, CT, about 40 miles from its R\&D facility in Danbury, CT. A separate, 100\% owned subsidiary, Fuel Cell Manufacturing Corporation, was established. ERC went outside its own organization to staff the company with experienced manufacturing personnel. Today, this 63,000 sq.ft. facility is capable of producing about $10 \mathrm{MW} /$ year of fuel cell stacks on a three shift basis. The purpose of this facility is twofold: First, to build reasonably priced demonstration plant hardware and, second, to establish all the manufacturing processes and engineering 
data required to design and build a first class commercial manufacturing facility.

In parallel with the manufacturing activity, ERC established a second subsidiary, Fuel Cell Engineering Corporation (FCE), to design, engineer, market, sell and service turnkey power plants. This activity began in the early 1990 s in partnership with Pacific Gas \& Electric Company (PG\&E), a major utility company, to provide engineering support during the early development phase. In 1992, FCE purchased the minority interest held by PG\&E and is now wholly-owned by ERC and has begun to build its own engineering staff while working closely with major A\&E organizations.

\section{B. Establishing a Customer Base}

Responding to a Notice of Market Opportunity (NOMO) for fuel cells initiated by a group of municipal utilities, members of the Arnerican Public Power Association, ERC was selected in 1990 to provide its technology and commercialization approach. This plan has been documented in an EPRI report ${ }^{\circ}$. The NOMO Review Team selected ERC after a 15-month scrutiny of ERC's designs. The team then formed the nucleus of the 12 member Fuel Cell Commercialization Group (FCCG), which now in 1994 has 37 members including investor-owned utilities, municipal utilities, rural electric cooperatives, and independent power producers. This buyers group represents potential future customers for ERC's DFC in U.S. and Canada.

A European Group, ARGE, consisting of ERC's licensing partner MTU, a subsidiary of the Daimler Benz Corporation, has been formed together with Elkraft Power Co. Ltd. and RWE AG, the largest utility companies in Denmark and Germany respectively, Ruhrgas, the largest private gas distributor in Europe, and Haldor Topsoe AS, a Danish catalyst and engineering company. These organizations are working together with ERC to commercialize the DFC in Europe.

The above entities represent a significant market in their own right. Part of ERC's plan is to create greater recognition of all fuel cells and especially the DFC. As part of the way to achieve this goal, ERC, in June of 1992, became a public company. This provides a vantage point for recognition of the fuel cell in the public investment sector for the first time. We believe this will further enhance future marketing efforts.

\section{The Market}

ERC estimates, based on projections made by the North American Electric Reliability Council" of approximately a $2 \%$ demand growth in electricity, that by 1998 about 750 GW of power generation equipment will be installed in the U.S. The demand estimate does not have a great impact on this number. Assuming a $2 \%$ continued growth from 1999, a demand-driven market of $15 \mathrm{GW}$ annually is expected for new equipment at the beginning of the 21 st century. Moreover, much of the existing equipment in the U.S. Was installed right before and after World War II and is now quite old. If we assumed an 
average plant life of 40 years, then the replacement market for the $750 \mathrm{GW}$ will be about $18 \mathrm{GW}$ per year. These estimates might be revised downward by the effects of demand side management and repowering projects. Upward revisions might be caused by new environmental restrictions on conventional plants and the impact of relicensing nuclear plants beginning in the year 2000. In any event, the potential market is huge. Fuel cells of the DFC type, available in megawatt and larger sizes coupled with high efficiencies and negligible environmental impact, could easily capture a significant portion of the market if cost targets in the $\$ 1,000-1,500 / \mathrm{kW}$ range can be realized. Several recent studies $^{12-14}$ on DFC type fuel cells indicate that credits from 1 to 6 cents per $\mathrm{kWh}$ can be available. Since a power plant investment or natural gas fuel at present prices are each roughly equal to 2 cents/kWh in either capital or fuel costs, the impact of these credits, derived from distributed generation benefits, could be quite large.

The municipal utility market is especially attractive for the DFC. Representing a $90 \mathrm{GW}^{15}$ potential, the average municipal utility is only $45 \mathrm{MW}$ in size. The 2000 municipal utilities generally have need for smaller size power plants. Units in the 2 to $10 \mathrm{MW}$ size, a range in which the fuel cell has little competition given present and future environmental standards, should be very attractive.

In a recent survey of utilities' ${ }^{10}$ conducted by ERC, the market seems to be in natural gas fueled units of less than $50 \mathrm{MW}$ in size. In the same study, it was projected that coal gasification plants would become attractive in the 2005-2007 time frame based on fuel pricing scenarios. ERC is planning for participation in this coal market via its Clean Coal $\checkmark$ project with Duke Energy Corporation.

\section{Demonstrations}

It is most important that potential customers have the opportunity to see units operating at highly visible sites. To this end, ERC began small-scale demonstrations of DFC technology at utility sites in 1989. The first test was conducted in Denmark in 1989-1990. Since then, ERC has tested additional units in California ${ }^{17}$, Louisiana ${ }^{18}$, Denmark ${ }^{10}$, and Germariy ${ }^{20}$, as well as at ERC. These tests have been conducted on both natural gas and coal gas fuels. Test durations ranged from 250 hours to 10,000 hours on units ranging in size from subkilowatt to $120 \mathrm{~kW}$.

A 2 MW demonstration, sponsored by a group of California utilities (the City of Santa Clara, California, the Los Angeles Department of Water and Power, Southern California Edison, Sacramento Municipal Utility District and the City of Vernon, California), the National Rural Electric Cooperative Association, EPRI, DOE and the Company, will start up in 1995. This will be the largest carbonate fuel cell demonstration conducted anywhere.

ERC is currently planning a second large-scale natural gas demonstration on the East Coast of the U.S. 
A 1.25 MW coal gas demonstration is planned as part of the Clean Coal V initiative at the Clean Energy Partners gasification site (Duke Energy Corporation).

\section{E. Financial Considerations}

ERC has spent about $\$ 200$ million on carbonate fuel cell development since 1976. Approximately $50 \%$ has been private sector funding and $50 \%$ U.S. government funding, mainly from the U.S. Department of Energy. ERC has heavily cost-shared its contracts with the government.

ERC estimates that about $\$ 250$ million in additional funding will be required in the 1994 1998 time frame. The Company expects to raise $\$ 150$ million from government and partners, including certain utility support to complete the product development and additional demonstrations. Additionally, another $\$ 100$ million is required to finance a commercial-scale manufacturing facility and to put into place the required marketing, sales, and after-market support systems. ERC expects to raise this funding from a combination of strategic joint ventures, bank loans, equipment leases, real estate mortgages, and additional equity financing.

The basis for additional equity financing has been established by becoming a public company in 1992. ERC has maintained a modest but continuous relationship with financial institutions, investment bankers and other private sector capital sources since June of 1992.

To date, virtually all of the technical and financial objectives of the Company have been met, and if this track record can be continued, ERC believes the desired financing will be realizable.

\section{F. Partners}

ERC has established a network of partners to help develop and commercialize the DFC on a worldwide basis.

In the U.S., ERC has been working with Fluor Daniel Corporation since 1981 on all phases of development including manufacturing, natural-gas and coal-gas system design, economic studies, market studies, power plant engineering and power plant construction. Recently, ERC has been working with Jacobs Applied Technology on stack module packaging.

In the utility sector, the Company is working with the 37 member Fuel Cell Commercialization Group to define the product and a model contract, address system planning issues, and develop and disseminate information on the DFC.

The Santa Clara Demonstration Project members and ERC are working closely on the 
$2 \mathrm{MW}$ power plant design and construction. Additionally, ERC is cooperating on economic studies of Nth generation power plants ${ }^{29}$.

In Europe, the Company is working closely with the MTU subsidiary of Daimler Benz AG. MTU is the world's largest supplier of packaged power plants for terrestrial and marine applications. In addition, ERC is working closely with several individual members of MTU's ARGE consortium.

ERC has conducted multiple natural gas fueled stack tests at Elkraft's power plant facilities outside of Copenhagen, Denmark. ERC is also conducting coal gas stack tests at RWE's facilities in Wesseling, Germany. Finally, ERC has been working with Haldor Topsoe AS since the 1980 s on fuel processing, reformer catalyst design and development and certain balance-of-plant systems.

In Japan, ERC participates actively in DOE-AIST sponsored meetings on fuel cells. Additionally, ERC exchanges technical information with Sanyo Electric Corporation and Mitsubishi Electric Corporation on liquid and natural gas fueled carbonate fuel cells, respectively.

More recently, ERC has entered into a sales agreement with United Power Association of Minnesota to market the Company's products in a five-state area in the North Central region of the U.S. As we move closer to our commercialization goals towards the end of the 1990s, ERC foresees establishing additional relationships with existing and new partners to assure a smooth transition into the market.

\section{G. Schedule}

The ERC commercialization activities began in 1988. Prior to that time, efforts were mainly focused on research and development, as well as preliminary design studies of various Direct Fuel Cell power plant configurations.

From 1988 to the present, ERC has continued its R\&D efforts under DOE and various utility contracts, broadened its design efforts to detajled levels, conducted small-scale field demonstrations on natural gas and coal gas, established a manufacturing facility, began construction of a 2 MW DFC natural gas demonstration plant, was selected for participation in a coal gas carbonate fuel cell demonstration project under CCT-V, and raised initial funds for DFC commercialization as a public company.

A schedule for non-financial activities is shown in Fig.v-5.1 for major commercialization tasks. The first natural gas 2 NW power plants are expected to be available in the later part of 1998.

Market entry for any new product is difficult because of the price-volume conundrum. ERC has addressed this issue in its commercialization plan by offering a special reimbursement provision to FCCG members who are purchasers of the first commercial 


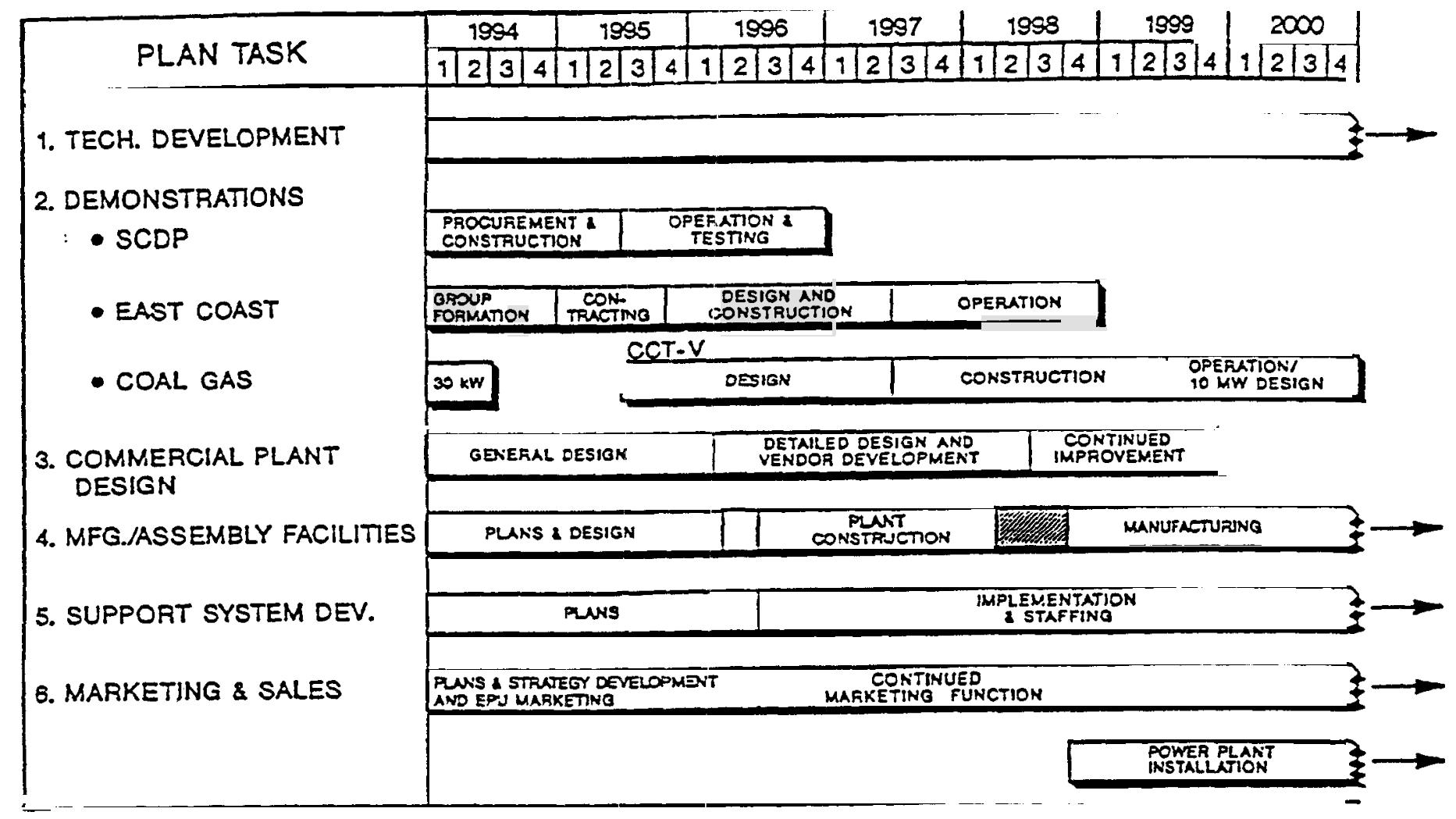

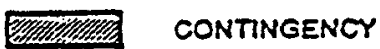

Fig. V-6.1 ERC Commercialization Program Overview \& Major Milestones for $1900 \mathrm{~s}$ 
units (identified as Early Production Units, EPU). In effect, these early buyers will pay a premium over the future commercial price and receive a payback based on a royalty stream from future commercial sales. This early buydown is not unlike that proposed by the U.S. Government under the "Commercialize High Efficiency Gas Technologies: Fuel Cells" section of the Climate Change Action Program initiative except that it is totally within the private sector. ERC welcomes the government initiative as a basis for additional market entry support for this important fuel cell technology, as long as the government program is complementary and not competitive with ERC's own program. 


\section{REFERENCES}

1. ERC, Molten Carbonate Fuel Cell Development, DOE Contract No. DE-AC2176ET11304, DE-AC03-76ET11304, 1986-1987.

2. ERC, "Development of Internal Refo-ming MCFC," EPRI Report GS-7221, RP 2344 1, May 1991.

3. ERC, "Development of Direct Carbonate Fuel Cell Stacks," Fuel Cell Seminar, Tucson, AZ, Nov. 29-Dec. 2, 1992.

4. Mitsubishi Electric Corp., "Development of IRMCFC at MELCO," DOE-AIST Technical Meeting, Tokyo, February 1994.

5. ERC and Fluor Engineers, Inc., "Assessment of a 6500 BTU/kWh Heat Rate Dispersed Generator," Final Report, EPRI No. EM-3307, November 1993.

6. ERC and Fluor Engineers, Inc., "Farametric Analysis of a $6500 \mathrm{BTU} / \mathrm{kWh}$ Heat Dispersed Generator," Final Report, EPRI No. EM-4179, August 1985.

7. ERC, Proceedings of the 2nd Symposium on MCFC Technology, ECS, Vol. 90-16, pp. 81-93, 1990.

8. ERC and Fluor Daniel, "Performance, Cost and Marketing of 200 MW Carbonate Fuel Cell Power Plants Based on Coal/Natural Gas/Phased Construction," Power Generator Conference, Orlando, FL, November 1992.

9. ERC and Fluor Daniel, "Design of Gasifiers to Optimize Fuel Cells," Proceedings, Gasification and Gas Stream CleanUp Systems Contractors Review Meeting, Morgantown, WV, June 1991.

10. Technology Transition Corporation and Instar Community Systems, Inc., "Public Power's Fuel Cell Commercialization Initiative," EPRI GS-7099, Project 1677-18, Final Report, January 1991.

11. North American Electrical Reliability Council, 1991. 
12. M.M. El-Gasseir, "Molten Carbonate Fuel Cells as Distributed Generation Resources," Case Studies for the Los Angeles Dept. of Water and Power, EPRI TR-100686, Project 1677-20, Final Report, May 1992.

13. Rumla, Inc., "Assessment of the Benefits of Distributed Fuel Cell Generators in the Service Areas of Central and SouthWest Services, Inc.," EPRI TR-102468, Project 1677-25, Final Report, October 1993.

14. Rumla, Inc., "Carbonate Fuel Cells and Diesels as Distributed Generation Resources - Economic Assessment of Application Case Studies at Oglethorpe Power Corp., EPRI TR-102163, Project 1677-24, October 1993.

15. Technology Transition Corporation, "The Market for Fuel Cell Power Plants Within Municipally Owned Utilities," EPRI GS-6692, Final Report, January 1990.

16. ERC, "Overview of ERC's Carbonate Fuel Cell Development Program," Proceedings of the Joint Contractors Meeting, pp. 239-249, FE/EE Advanced Turbine Systems Conference, FE Fuel Cells and Coal-Fired- Heat Engines Conference, U.S. DOE, METC, Morgantown, WW, August 1993.

17. PG\&E, "Fuel Cell Pilot Plant with $70 \mathrm{~kW}$ Stack Operational Test,"Report 007.493-1, 1994.

18. ERC, "The Direct Fuel Cell - A High Efficiency Electric Power Generator," American Power Conference, Chicago, IL, April 1994.

19. - Huber, W.J., ERC's Carbonate "Fuel Cell Power Plant Commercialization Progress," Proceedings of the Third Annual Fuel Cell Contractors Review Meeting, DOE/METC-91/6120, pp 74-81, Morgantown, WW, June 1991.

20. RWE, "Zur Verstromung von Kohlegas," presented at Industrieseminar Brennstoffzellen, des Zentrums fur Sonnenenergie-und Wasserstoff-Forschung, New-Ulm, January 25, is94.

21. ERC and Fluor Daniel, Inc., "Cost and Performance of an Nth Generation 2 MW Carbonate Fuel Cell Power Plant Based on the Santa Clara Demonstration Project Design," Fuel Cell Seminar, Tucson, AZ, November 1992. 
V-7. IFC Perspective on Fuel Cell System Commercialization*

International Fuel Cells Corporation (IFC), a subsidiary of United Technologies Corporation, is committed to the commercialization of fuel cell technologies for the spectrum of applications including space and military, stationary power and vehicle propulsion. The primary focus of IFC's business since 1959 has been on developing, manufacturing, and marketing fuel cell power plants which integrate the fuel cell power conversion, fuel processing, power conditioning and control technologies into complete, independent operating systems, In pursuing these activities, IFC conducts programs which leverage synergies among the individual fuel cell and subsystem technologies to select the appropriate technology mix for the specific application requirements

In all, IFC has built and supplied to customers 342 power plants in 18 different models utilizing alkaline, PAFC, MCFC and PEM technologies. This represents a total installed capacity of 37,000 kilowatts and accumulated operating experience of 900,000 hours. The power plants were used in space and military applications, and utility service.

IFC systems for space applications have utilized the alkaline technology. The current product is the on-board power generation system for the space shuttle. This power plent operates on pure hydrogen and oxygen and is designed to meet the rigorous requirements of space applications. The power plant and its characteristics are shown in Figure 1. The present focus in this market is to expand product capabilities beyond the shuttle application by the development and application of the PEM technology. This development has proceeded to the point where a complete hydrogen-oxygen fueled demonstration power plant has been designed, fabricated and has successfully completed initial system testing (Figure 2). Extended testing to verify endurance and start/stop capability is underway. Designed originally for underwater application, this system provides the design basis for expanded space and military applications.

For stationary utility applications the phosphoric acid technology is in the early stage of commercial application. It offers potential advantages for on-site and multi-mw dispersed generation applications. IFC's commercialization process is based on the initial introduction of the $200 \mathrm{~kW}$ natural gas fueled $\mathrm{PC} 25^{\mathrm{N}}$ power plant (Figure 3 ). The specification for this $200 \mathrm{~kW}$ power plant, which meets the technical and operating requirements of the on-site market is summarized in Table 1. Multiples of this unit or multi-mw power plants based on PC25 componentry and technology is applicable to large industrial application or utility dispersed applications.

The PAFC technology is also being pursued for transportation applications. The initial IFC transportation focus is for application in buses and other heavy duty vehicles. For the longer term the PEM technology has advantages and is being pursued for

* Submitted by P.J. Farris. 
PC25 CHARACTERISTICS

\begin{tabular}{|c|c|c|}
\hline CHARACTERISTICS & STD. PC25 & PC25 OPTIONS \\
\hline ELECTRICAL & $\begin{array}{l}\text { - } 200 \mathrm{~kW} / 235 \mathrm{KVA} \\
\left.\text { (-20 to } 110^{\circ} \mathrm{F} \text {, up to } 500 \mathrm{ft} .\right) \\
-480 / 277 \text { Volt. } 60 \mathrm{~Hz} \\
-400 / 230 \text { Voit. } 50 \mathrm{~Hz} \\
\text { - Grid-Connected }\end{array}$ & $\begin{array}{l}\text { - Grid Independent/Grid- } \\
\text { Synchronized } \\
\text { - Single unit operation on } \\
\text { dedicated circuits } \\
\text { - No overload capacity } \\
\text { - Dual Grid-Independent } \\
\text { Grid-Connected }\end{array}$ \\
\hline $\begin{array}{c}\text { THERMAL ENERGY AVAILABLE } \\
\vdots \\
- \\
\ddots \\
\ddots\end{array}$ & $\begin{array}{l}->700,000 \text { Btu/hr @ 1400F } \\
\text { - Single-Walled Hex }\end{array}$ & $\begin{array}{l}\text { - }>700,000 \text { Btu/hr @ } 140^{\circ} \mathrm{F} \\
\text { - Double-Walled Hex } \\
\text { - High-Grade Heat (Hot Water) } \\
\text { - }>350,000 \text { Btu/hr @ } 250^{\circ} \mathrm{F} \\
\text { and } \\
\text { - }>350,000 \mathrm{Btu} / \mathrm{hr} @ 140^{\circ} \mathrm{F}\end{array}$ \\
\hline INTERFACES & $\begin{array}{l}\text { - Pipeline Natural Gas } \\
\text { - Make up City Water } \\
\text { Requirement } \\
\text { - Facility Nitrogen Supply } \\
\text { Required } \\
\text { - Simple Power Plant Control } \\
\text { Panel With Interfaces For } \\
\text { Diagnostics and Servicing }\end{array}$ & $\begin{array}{l}\text { - Peak Shaved or Btu Balanced } \\
\text { Gas } \\
\text { - Up to } 4.2 \% \mathrm{O}_{2} \\
\text { - Remote Data Acquisition and } \\
\text { Control } \\
\text { - External Control and Monitorino } \\
\text { System }\end{array}$ \\
\hline STARTUP & - Electric Heater & - Gas-Fired Heater \\
\hline POWER PLANT MODULES & $\begin{array}{l}\text { - Power Module }\left(10^{\prime} \times 10^{\prime} \times 18^{\prime}\right) \\
-40,000 \mathrm{lbs} . \\
\text { - Cooling Module }\end{array}$ & - Delete Cooling Module \\
\hline
\end{tabular}

TABLE I 
passenger car and other light duty vehicle applications. IFC PEM technology programs are aimed at establishing the tectinology base for these applications. A major technical hurdle for vehicle use is the ability of the PEM cell stack to operate on hydrocarbon fuels. Under a government sponsored program, feasibility testing of key elements of a methanol fueled system have been demonstrated. Further development and verification testing is required before this technology can proceed to commercial applications. This development effort will focus on establishment of required performance levels (watts per square foot at voltage associated with the required efficiency) while operating on processed fuel and air, and developing a power plant design with intrinsic materiais cost $\mathbf{\$}$ /sq.ft. s suitable for commercial applications. In addition, the overall system design and cost will address the low temperature cell's limited ability for integration with the fuel processing system.

The MCFC technology is in the early development stage. This technology has the potential for complementing the PAFC fuel cell base for electrical applications initially for large multi-megawatt stations and eventually for integration with coal gasification systems to provide highly efficient, low emissions coal fueled power plants. Under government contract IFC has built and tested a full scale short stack molten carbonate cells $(25 \mathrm{~kW})$ and has established complete power plant sysem designs based on that technology. The present MCFC focus is on resolving fundamental cell and stack technical issues to enhance system scale-up and demonstrations and provide the basis for commercial power plant systems.

The solid oxide fuel cell (SOFC) offers application potential similar to the MCFC. IFC's principle focus in this technology is on fundamental materials and design issues which need to be resolved before the inherent benefits of the solid electrolyte technology can be realized in practical power plants. This research has resulted in the identification of a cell concept for improving performance at operating temperatures on the order of $700^{\circ} \mathrm{C}$.

Each fuel cell technology has features which enhance its potential for specific types of applications. An independent consultant's study (Reference 1) has reported that the projected costs for all fuel cell stacks are very similar. Any differences in power plant costs are related to system, installation, and/or application requirements. IFC's multi-technology focus provides the basis for taking advantage of benefits of each technology to select the appropriate system design and power plant configuration for each application. The PAFC technology is most advanced and is the focus of IFC commercial efforts on cost reduction, customer acceptance, and market expansion.

II COMMERCIALIZATION FOCUS

IFC has established and is implementing a comprehensive plan for commercializing the phosphoric acid technology for on-site applications. The plan covers all the technical, manufacturing, product support, and marketing elements necessary for 
commercialization. IFC's approach is based on a process of:

- establishing technical feasibility of providing an on-site energy service utilizing natural gas fuel cell power plants

- introducing equipment into limited commercial service to verify the manufacturability and the field serviceability by the manufacturer, suppliers and users and to demonstrate the environmental and conservation benefits

and

evolving the economic viability of the equipment to permit widespread market applications.

On-site fuel cells are now at the point where a limited commercial market for the power plant has been established and the environmental and conservation benefits of the technology have been verified.

The initial step of the process was completed by the late 1980's. This effort began as a jointly sponsored activity with the Natural Gas Industry in the late 1960's and led to the development by the mid 1980's, under gas industry, DOE and GRI sponsorship of an experimental power plant design that was field tested by individual gas and electric utilities and marketing and industrial customers in a representative cross section of building market segments and geographical locations. The high efficiency, low environmental intrusion and rapid response to load demands of the unit established the technical feasibility of the design and technology base. With indications of support from the market for a 200 kilowatt size power plant to serve a broad range of commercial and multifamily buildings and light industrial applications, and based on results from Government and privately sponsored work through the mid 1980 's, IFC committed to proceed privately with the design and development of the PC2 $5^{m}$ commercial unit. Four preprototype units were manufactured and successfully operated at customer sites in an activity funded at over $\$ 25$ million by IFC and its customers. These units accumulated more than 40,000 hours of operation in the late 1980's and demonstrated that the 200 kilowatt design resolved the remaining performance and operating issues.

The limited commercialization phase of the process began in 1990. An initial lot of orders from customers in the U.S., Europe, and Asia for 56 commercial 200 kilowatt power plants provided the basis for IFC's additional \$85 million commitment. These fund's were used to complete the design of a commercial power plant, to invest in a manufacturing facility, to establish and train a manufacturing organization, and to subsidize the production and delivery of the units which began in early 1992. In addition, a field support organization was established and the equipment 
documentation and training procedures were developed to support the customer's capability to site, install and service power plants in a commercial operation environment. This support capability included:

- Personnel training, installations and servicing manuals, applications, installations and checkout assistance

- World wide monitoring, service support, spare parts provided to individual units, including advice and field assistance for problem resolution on a 24 hour basis.

- :Design modification and retrofit kits for installed units to overcome operating problems identified in operation

and

Certification and listing of the PC25 power plant by AGA to minimize the licensing and permitting process.

Manufacturing of the initial group of units was completed by late 1993 and over 70 units have been manufactured to date. The manufacture of these units required investment in facility, worker training and supplier development. The experience in worker training and supplier development is essential for long term commercialization and it could only be achieved through real production and sales of commercial units. As a result of the experience to date with the initial group of power plants, IFC has verified the manufacturability of the equipment, has established a sound production costing data base and developed supplier relationships for key subsystems.

As of April 1994, there are $40^{\circ}$ PC25 power plants in operation worldwide. These units are producing electric and thermal energy for various types of applications. The first unit was started in April of 1992 and the remaining units of that group are in the process of being sited. Cumulative fleet operating time is over 300,000 hours and four power plants have exceeded 12,000 hours of operation. Average fleet availability worldwide is 95 percent; one power plant has achieved an availability of over 99 percent. The power plant operating experience has been continually reviewed, and a number of design improvements have been retrofitted. Evaluation of the equipment in operation at customer sites has verified the high efficiency and extremely low emissions of the power plant. In addition, a high level of confidence in the field serviceability of the equipment has been established as demonstrated by the high operating availability rates in the field.

The process of developing the market for fuel cell generating equipment is critical to the commercialization process and this task has been an integral element of this process from the beginning. The primary thrust for addressing this task has been the 
development of a customer base that would utilize fuel cell power plants for providing an energy service and to work with those customers to insure that all of the critical elements necessary to establish that business are addressed. IFC is working with potential energy service providers such as gas and electric utilities and industrial and independent power producers as an inherent element of its commercialization process. This customer involvement ensures that the fuel cell equipment meets all of the physical and operational requirements for providing that service and also ensures that ancillary requirements such as cost effective installation and servicing approaches have been addressed. These activities have included formal and informal interactions with the owners of the fuel cell power plants and have resulted in design improvements aimed at reducing maintenance and installation requirements and specification modifications for more cost effective power plant designs.

A $\$ 30$ million product improvement cost reduction program was started in late 1992 concurrent with IFC's efforts to commercialize the 200 kilowatt power plant and, in addition to providing the cost reduction yield, established the format for a continuous cost reduction improvement process necessary for commercialization. This format is a vertically integrated structure with well defined roles comprising IFC as the developer/manufacturer of the fuel cell stacks and the power plant module, subsystem suppliers who work with IFC to define an integrated cost reduction plan for their respective subsystem/components, and with the owners of initial units who provide input on design requirements and trade offs. This approach provides involvement and strong technical input from knowledgeable industrial experts and product users. Conducted in paralle! with the manufacturing, delivery and support of the commercial production units, the product improvement cost reduction program is aimed at developing improvements in the design and technology base as well as working with suppliers to identify approaches for reducing the costs of the materials and components utilized in the manufacture of the power plant. This program is planned be completed by the end of 1994 and will provide a power plant design with a 50 percent reduction in the direct manufacturing costs from the cost of the initial design manufactured in 1992. The program is on schedule within budget and is achieving cost reduction goals established in 1992. Power plants based on this improved design are being offered for commercial delivery in 1995 at a price of $\$ 3,000$ per kilowatt. While this price is acceptable for special purpose application it is too high for widespread market acceptance.

The next step in the commercialization process involves continued cost reduction and the expanded market acceptance of the on-site fuel cell energy service. These steps are highly interrelated since cost reduction is derived from continuing improvements in the fuel cell technology base and from the application of innovative manufacturing technology which can only be justified by volume production.

IFC's cost reduction strategy has three major thrusts: 
- The development and investment in process manufacturing technology aimed at reduced manufacturing costs.

- Investment in adapting technology from related industries such as fuel processing and power electronics to specific fuel cell power plant requirements. This activity is conducted in conjunction with suppliers in these fields.

and

- Technology advancement in the basic fuel cell technology aimed at providing higher power density, increased operating tolerance to reduce system complexity and integrated component designs to reduce number of system components.

The challenge to completing the commercialization process is to obtain sufficient user interest in terms of power plant sales and increased application to justify private sector investment to provide both manufacturing process and power plant technology improvements necessary to achieve the mature price objective. The next section describes IFC's approach for accelerating this process.

\section{APPROACH TO EXPEDITING COMMERCIALIZATION PROCESS}

One power plant cost reduction thrust requires the achievement of sufficient sales volume to warrant investment in innovative production processes. This can only be achieved through wide spread market acceptance of the on-site energy service. To accelerate this market acceptance IFC is recommending a Government subsidy program that would make these units economically attractive in a range of applications which would be representative of widespread use. Government support of subsidized purchases for widespread market application is a high priority objective for IFC and is warranted because it is a means to accelerate the benefits from fuel cell applications in the United States and to insure that the U.S. industry maintains its present lead in fuel cell technology.

Concurrently IFC has established a development plan which is implementing specific additional cost reduction improvements that together with volume production technology are the basis for achieving a market price of $\$ 1,500 / \mathrm{MW}$. This market price will expand the scope of the market opportunities beyond the subsidized and limited premium applications and permit penetration of a significant portion of the power generation market. Support by the government as well as the private sector for research and development aimed at cost reduction is also warranted since these technology improvements are necessary to maintain the United States technology lead and since many of these improvements are applicable to more advanced fuel cell technologies. 
EPRI, GRI and AGA can provide a role in this commercialization effort by supporting focused R\&D aimed at specific technology improvements, by sponsoring application demonstrations and by promoting the purchases of government subsidized units by their industrial members.

The public sector benefits for accelerating the commercialization of fuel cells and the PAFC technology are substantial. At the competitive price of $\$ 1,500 / \mathrm{kW}$ the fuel cell power plant will be highly competitive and implementation of the commercialization plan will establish wide-spread market acceptance. On a national basis accomplishment of these objectives will provide:

- Creation of skilled jobs in fuel cell manufacturing, installation and maintenance and servicing.

- Creation of equipment suppliers base with capabilities in fuel processing and power conversion which can be applied to a range of other advanced technology products.

- Increased exports of power generation equipment to both developed and developing countries around the world.

- Significant reduction in both primary emissions such as NOx, SOX, CO and NMHC and greenhouse gases such as carbon dioxide

and

- Reduction in fuel resources required to supply the thermal and electric energy requirements for commercial applications.

These benefits extend beyond the immediate user and supplier of fuel cell systems and are in themselves justification for public sector support of the commercialization effort.

PJF $400 G$

September 6, 1994 


\section{REFERENCES:}

1. "THE ROLE OF FUEL CELL TECHNOLOGY IN THE POWER EQUIPMENT MARKET - POLICYISTRATEGY ISSUES" - PREPARED FOR WORLD FUEL CELL COUNCIL BY ARTHUR D. LITTLE, SEPTEMBER 1993. 


\section{ORBITER ALKALINE FUEL CELL POWERPLANT}

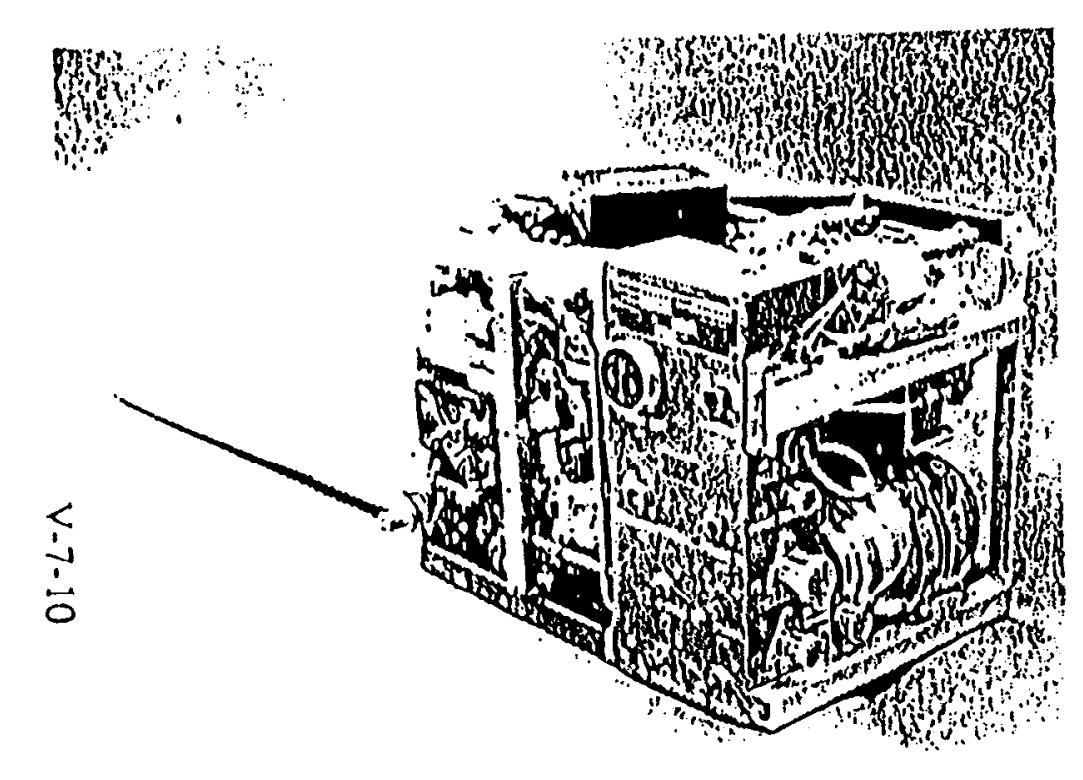

Characteristics

- 28 volt dc output

-12-kW nominal

-16-kW maximum

$.119 \mathrm{~kg}$

- $10 \mathrm{~kg} / \mathrm{kW}$

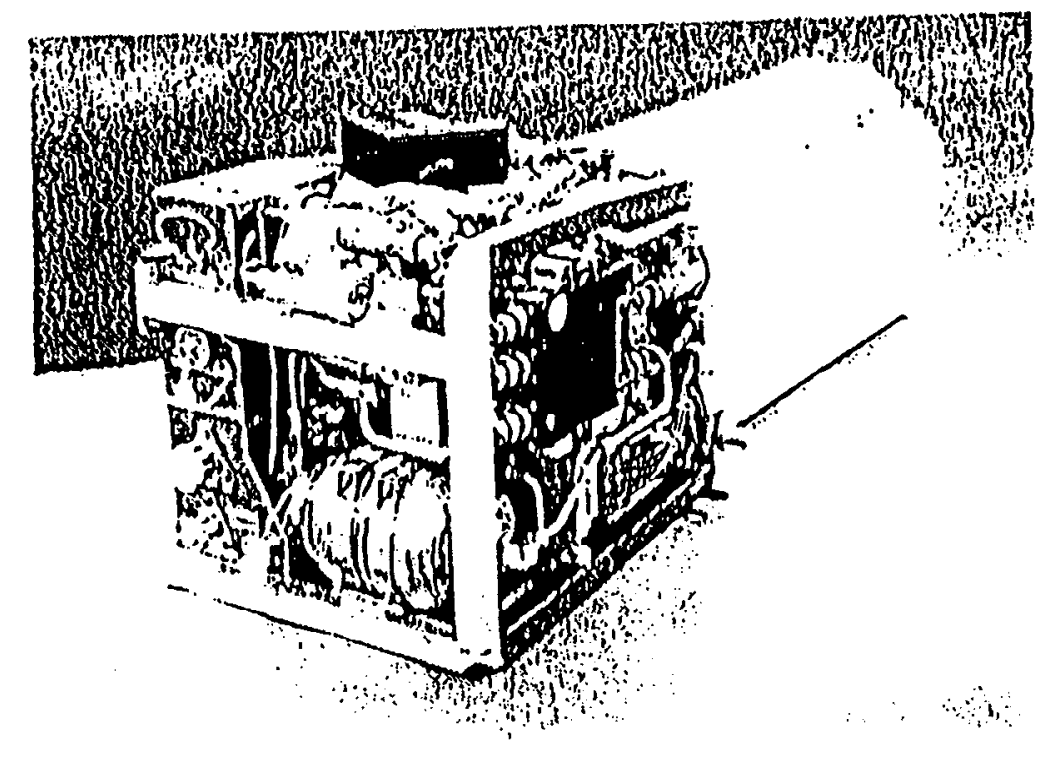

Installation

- 3 per Orbiter

- All on-board power

- $\mathrm{H}_{2} \mathrm{O}$ for crew drinking and vehicle cooling

- $2400 \mathrm{hr}$ service life 


\section{HYDROGEN/OXYGEN FUEL CELL POWERPLANT}

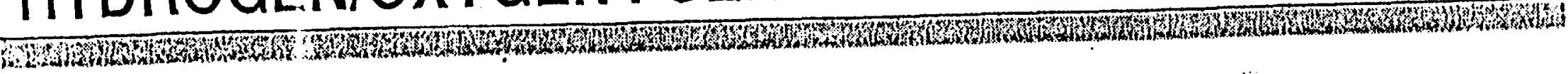

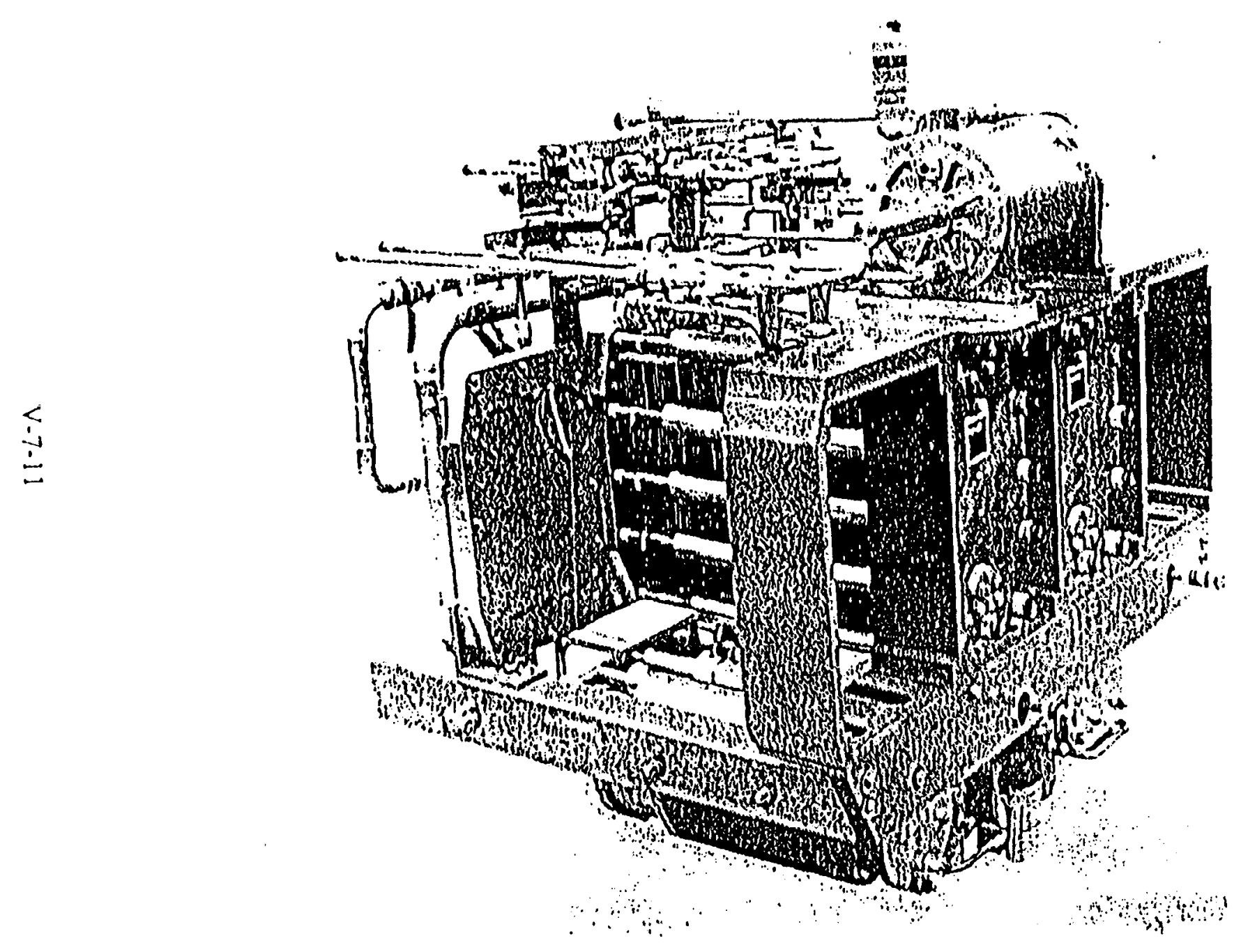

Fig. V-7.2 Hydrogen/Oxygen Fucl Cell Powcrplant 


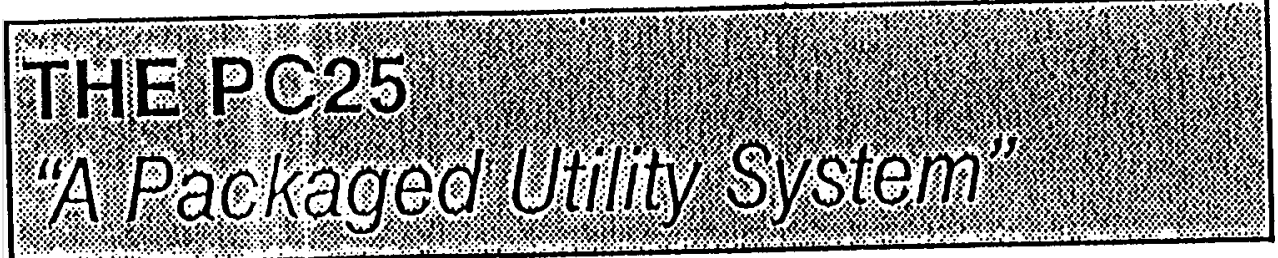

\section{0-kW FUEL CELL POWER PLANT}

$\stackrel{\dot{1}}{\dot{N}}$

Power Module

- Fuel processor

- Fuel cell power section

- Power conditioner

- Customer heat exchanger

- Controller

- Diagnostics

- Weather-proof enclosure

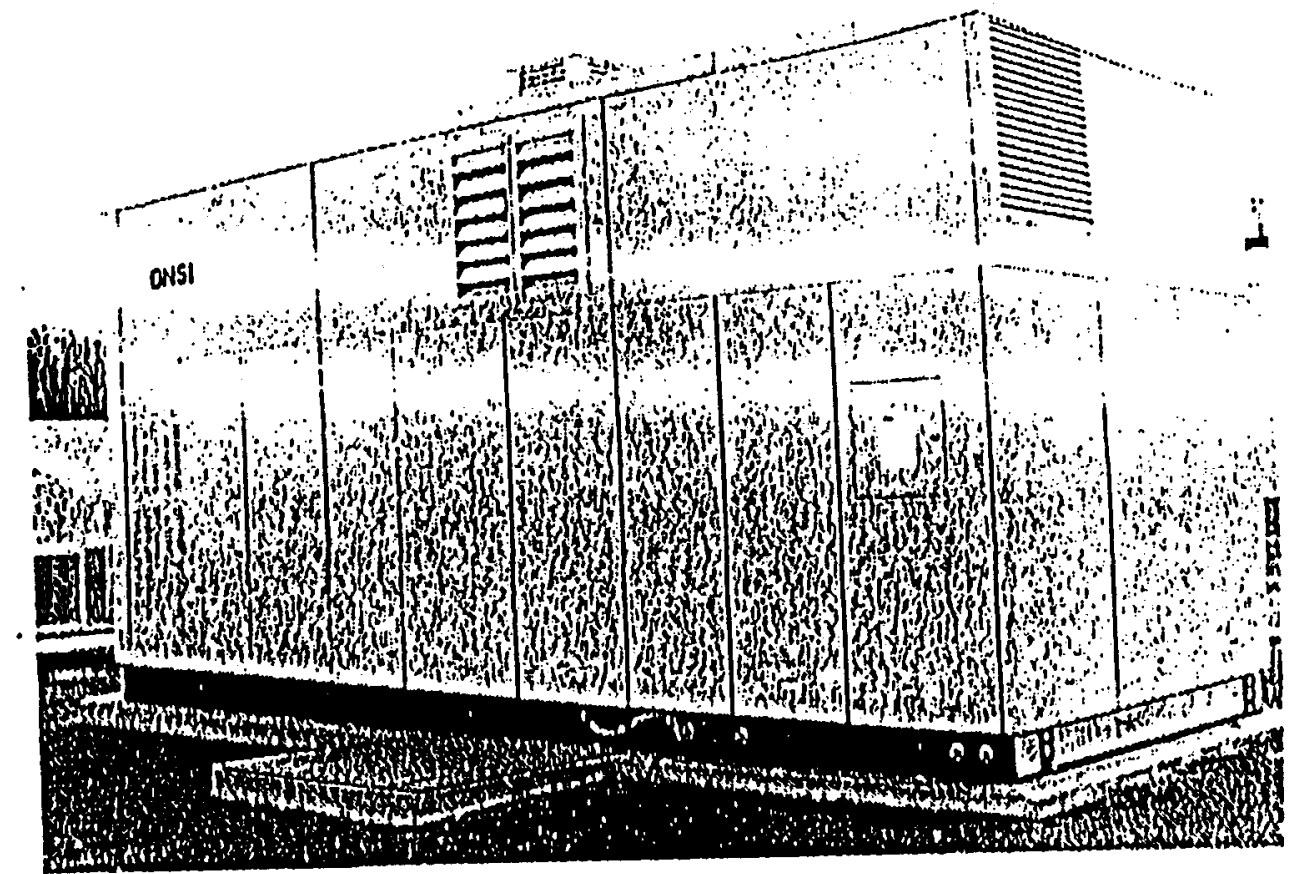

FCJ3455 
V-8. Commercialization of M-C Power's IMHEX Molten Carbonate Fuel Cell Power Plants*

\section{V-8.1 Introduction}

M-C Power Corporation is one of the world's leading developers of molten carbonate fuel cells (MCFCs). Fuel cells produce electric power without any combustion through the electrochemical reaction of air and hydrogen produced from fuels, such as natural gas. MCFCs are second generation fuel cells which offer high efficiencies, low emissions, and potentially low costs. Since its incorporation in 1987, M-C Power has focused on developing and implementing technology which will enable it to combine individual MCFCs into stacks large enough to generate commercial quantities of electric power. It is generally recognized that an MCFC power plant will need to generate at least one megawatt (1,000 kilowatts) of electric power in order to be a cost-effecive product during the market introduction phase.

The M-C Power MCFC stack is configured in what is knoun as the IMHEX ${ }^{\circ}$ design. This design uses internal, as opposed to external, manifolding to distribute fuel and air to individual cells within the stack. M-C Power has already successfully scaled-up the IMHEX stack design to commercial size cells and has verified the technology in four 20-kW short stacks. Before the end of 1994, M-C Power and its Team expects to complete the design; manufacture, and testing of a 250 -cell stack and $250 \mathrm{~kW}$ power plant. Funding for these technology developments are through contracts with agencies of the United States government, not-for-profit research organizations, and utility companies. The IMHEX Team's plan is to have a commercially viable IMHEX ${ }^{0}$ power plant in operation during the late 1990 s and to begin deliveries of market entry units by the end of the decade.

\section{A. Program Overview}

The IMHEX ${ }^{\otimes}$ commercialization program is a comprehensive plan of activities needed to provide the technology, development and demonstrations required to commercially offer a market entry product. M-C Power and its commercialization Team are conducting this coordinated program to develop and deliver market-responsive power plants by the late 1990s. These development activities have been organized into two major phases, Technology Development and Product Design \& Improvement.

A major portion of the Technology Development phase (1987 through 1995) has been complcicd. This phase of the piogram provided the initial cevelopnent and verification of the commercial-scale IMIHEX ${ }^{\otimes}$ stack hardware. These efforts focused on fuel cells with active area of $1 \mathrm{~m}^{2}$ per cell $\left(11 \mathrm{ft}^{2}\right)$ and component manufacturing processes which provided high quality and repeatability. In addition, various process engineering designs and equipment technologies are being evaluated to address power

: plant integration requirements. These activities are progressing toward the operation of two, $250 \mathrm{~kW}$ process and product development power plants in 1994 and 1995 . This

\footnotetext{
* Submitted by P. Tarman.
} 
incremental approach utilizes 250-cell IMHEX ${ }^{\otimes}$ stacks to verify M-C Power's technology in commercial-scale, commercial-height building block. The balance-of-plant component selection, process integration, skid design and unit assembly approaches provide the technical foundations for commercial product definition and development.

The Product Design \& Improvement phase (1994 through 1999) will concentrate on advanced stack manufacturing technologies and power plant design and engineering efforts directed at a commercially viable product. These efforts are directed at the cost reduction and power plant reliability issues which must be resolved to allow the introduction of a market-responsive product prior to the turn of the century. This phase culminates in the construction and operation of pre-prototype and prototype MW-class units in the 1997/1999 time frame. These units will address the reliability, durability and cost-effectiveness issues which must be verified for marketplace acceptance.

\section{B. Product Overview}

Product definition activities over the past few years have solicited input from members of the Alliance to Commercialize Carbonate Technology (ACCT). These data have helped shape our targets and concepts for a market entry unit. A preliminary concept for this unit has been developed and is illustrated in Fig. V-7.1. This unit is a 1 . MW power plant that achieves a $50 \%$ electrical etticiency (based on the higher heating value of natural gas) and an overall efficiency of $80 \%$. The concept includes three skids: power module, mechanical module and electrical module. The power module integrates four 200-cell IMHEX stacks and a I MW capacity plate-type reformer into a single temperature/pressure vessel assembly. The mechanical balance-of-plant components, such as process air turbo-machinery, heat recovery steam generator, water treatment, and fuel pre-processing, are integrated into a truck transportable skid or the mechanical module. the power conditioning equipment and power plant controls systems are integrated into the third module. The overall layout is approximately 35 by 30 feet and achieves approximately $1 \mathrm{~kW}$ per square foot of site space. The input from the ACCT organization has also established a marketplace installed price target of $\$ 1500 / \mathrm{kW}$. The team's goal is to develop the technology required to achieve these product characteristics during the market entry phase of commercialization.

\section{Market Overview}

IMHEX ${ }^{*}$ power plants offer the power generation industry several advantages over conventional systems. These units operate at very high electrical efficiency (50\% as compared to $28-36 \%$ for other power generating devices of similar capacity), are noiseless, generate virtually no pollutants, can use a variety of fuels, and offer operating flexibility and power quality not available from conventional technologies and can be applied to distributed gereration, cogeneration and compressor station sites. The IMIHEX ${ }^{\odot}$ Team's MN-class, market entry product is projected to be natural-gas fueled. Most importantly, these power plants are small capacity modular units that can be located close to consumer loads and within urban area distribution networks. 


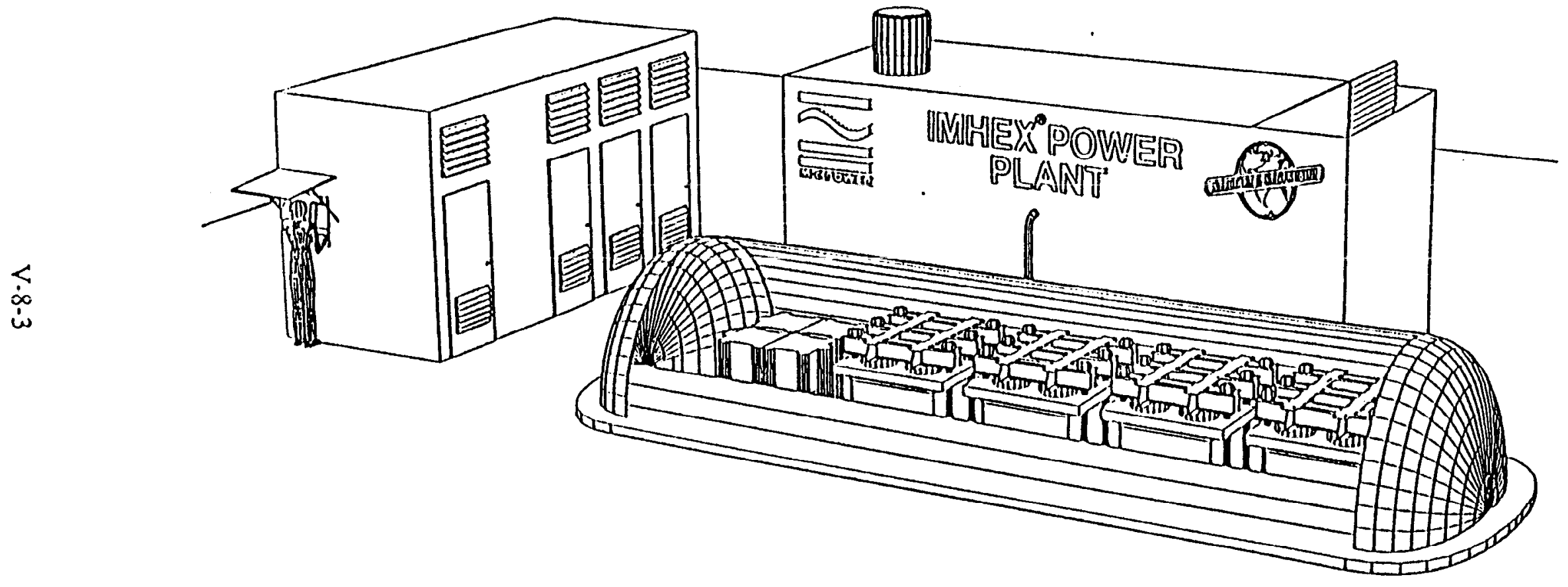

Fig. V-8.1 , Conceptual Design for MW-Class IMHEX ${ }^{\circledR}$ Fuel Cell Power Plant 
This modular capability has several advantages over large central power stations and conventional transmission and distribution (T\&D) networks. First, energy services can be customized to meet the energy requirements of the customer by siting plants at a specific building or facility providing both cogenerated heat and electricity. In addition, siting within the distribution network reduces the load on the T\&D network and eliminates line losses associated with transmission from remote central power stations. When strategically sited within the distribution feeder system, modular power plants can improve power quality and reliability for customers. These units can also assist utility companies in controlling and reducing capital expenditures by deferring distribution system upgrades and allowing incremental additions of generation capacity. The Team believes that the market for distributed power and specifically the IMHEXX ${ }^{\otimes}$ power plant will continue to grow as utilities seek efficiency advantages needed to compete in increasingly competitive markets and as environmental resistance to central power stations and high voltage power lines increases.

\section{V-8.2 Commercialization Strategy}

$\therefore$ The IMHEX Team's strategy is centered around the integration of six key elements into a cohesive commercialization plan with both near-term and long-term goais. The long-term goal, beyond the year 2010 , is to provide customers with a range of cost-competitive, full-featured IMHEX fuel cell products. These products, serving a wide variety of markets, would range from small capacity distributed generation and cogeneration power planis initially to large capacity central station, repowering, and integrated coal gasification facilities in the furure. Achievement of this long-ierm goal requires achieving the shorter-term goal by the year 2000 that provides strong business opportunities. Therefore, our near-ferm goal is to establish a self-sufficient business which focuses on a single product that minimizes risks and maximizes competitive advantages, a product that can be sold in low-production volumes at a profit without substantial subsidies.

After evaluating the market opportunities, customer requirements, technology maturity, risks, and competitive product characteristics, the Team developed a Commercialization Program focused on this initial product offering. The goal is to introduce a low-price (approx. $\$ 1,500 / \mathrm{kW}$ ), durable, MW-class IMHEX fuel cell power plant and begin deliveries prior to the turn of the century. Primarily, this product will be natural gas-fueled and applied to distributed generation, cogeneration, and compressor station sites.

\section{A. Commercialization Elements}

Successfully moving an advanced technology, such as the IMIHEX fuel cell porer plant, from the stack research and development stage to a viable commercial business requires much more than technology and its verification. A thorough approach integrates six key elements into a comprehensive commercialization plan and its execution: 
- Motivated Customer - End users that support product development, direct product evolution, and represent the marketplace.

- Committed Business Partners - Team members, strategic alliances, and sponsors that provide the capabilities and commitment for milestone achievement.

- Sound Technology Base - Research and development that provides the foundation for integrated systems which meet marketplace requirements.

- Competitive Product Evolution - Demonstrations that verify product performance, durability, and cost and provide the market confidence.

- Established Manufacturing Capability - Facilities that provide flexibility for development and establish the foundation for commercial production and assembly factories.

- Responsive Distribution Infrastructure - Marketing, sales, distribution, and services that provide the infrastructure to support marketplace needs.

Motivated Customer. End users provide the opportunities and demand for the commercial product. They establish the requirements and characteristics which determine if the product is market responsive and represent the market pull which drives the developments and affords the financing. The Alliance to Commercialize Carbonate Technology (ACCT) was formed in 1991 and consists of representatives from over sixty companies interested in the developing IMHEX technology and supporting product commercialization. Utility organizations, industrial energy users, pipeline companies, independent power producers, and IMHEX ${ }^{*}$ Team members are all represented in ACCT. These organizations provide a vital link between the marketplace requirements and definition of a market-responsive product.

The power generation industry in the United States is continuing a process of evolutionary change that began in the 1980s. Increased competition and stronger environmental restrictions are at the center of this change. Competitive bidding within the power generation industry is providing an increasing share of new capacity. Over half of projected new capacity is non-utility generators (NUG), and as it now appears, open transmission system access is on the horizon. Natural gas is becoming the fuel of choice for most new capacity or repowering projects (48\% of existing NUG capacity is gas). The typical eleciric utility is likely to appear quite different after the year 2000, and this evolution may continue for another ten years.

Environmental issues are crcating uncertainty in the power business. These issues may be manifested in air emissions permits or allowances for $\mathrm{NO}_{x}$ or $\mathrm{SO}_{2}$, energy taxes, $\mathrm{CO}_{2}$ limits, "carbon taxes", EMF limits, etc. and will gain importance as companies seek permits for generation, transmission, or distribution facilities.

- Utilities are "down-sizing" with the goal of becoming the lowest cost supplier of electricity and are beginning to examine the concepts of "energy service" to improve their 
economic competitiveness and retain their customer base. These competitiveness issues are leading utilities to examine the benefits of distributed generation. Siting small capacity generation near the customer loads or at distribution substations can improve system efficiency and power quality while reducing distribution system costs.

Over the past few years market surveys have been conducted with ACCT representatives to assess their product requirements and decision criteria. The primary results can be summarized in very few words - durability, performance, and costeffectiveness. Preliminary marketplace inputs indicated that the definition of costcompetitiveness is approximately $\$ 1500 / \mathrm{kW}$ in capital cost, but ultimately, it is the customer's cost-of-electricity (COE) that defines cost-effectiveness. COE is territory specific and should include application specific benefits and savings. Initial studies by utilities in cooperation with EPRI have shown that distributed generation at some sites can provide benefits of 30 to $70 \mathrm{mils} / \mathrm{kWh}$ in addition to the average generator's COE.

The marketplace has also indicated that initial introductory market (less than 1030 units) will support an elevated pricing structure of greater than $\$ 2000 / \mathrm{kW}$, especially if royalty payback can be provided. In the middle market period (after the initial 10-30 units) cost-competitive pricing ( $\$ 1500 / \mathrm{kW}$ or less) is required to achieve a self-sufficient production business.

With the increasingly competitive environment in which the utilities find themselves, an advanced product, regardless of its ultimate promise, must first meet the customer's expected durability and reliability criteria. If an introductory product does not meet customer expectations, follow-on orders will not materialize. As a result, the IMHEX Team has selected a step-wise power plant demonstration effort which will result in a series of highly durable and reliable MW-class verification units.

.. Individual companies have different views of how fuel cell power plants will be applied within their resource mix. As a result, no clear, single application or product definition arises from these generic surveys. However, all ACCT members indicate large opportunities for fuel cell power plants exhibiting high performance and low emissions. The broadest segment of ACCT organizations would apply IMHEX power plants in smaller capacity distributed generation applications, but this segment diverges based on specific site criteria, such as by-product heat utilization and operating strategy. Other organizations focus on more traditional larger scale facilities and/or repowering applications in the $30-10-100-\mathrm{MW}$ range.

During 1993 the ACCT members responded to a survey which addressed performance and cost issues. Prior discussions indicated that power plants must be price-competitive even during the introduction phases of commercialization. A series of power plant specification options were presented which traded off part-load performance characteristics against plant cost and unit capacity. The results indicate that ACCI members preferred the high performance options over both lower cost and smaller capacity options. 
Committed Business Partners, Team members, strategic alliances, and sponsors provide the capabilities, perspective, facilities, infrastructure, commitment, and financing to achieve the development milestones and to establish the business structures and financing.

As a small start-up, advanced technology company, M-C Power's primary focus is fabricating and manufacturing commercial-scale IMHEX fuel cell stacks. To successfully penetrate the power generation marketplace, $M-C$ Power realized that the product must be a completely integrated, self-sufficient power plant which produces electricity and useful heat. Development and introduction of this product requires skill, experience, capabilities and resources beyond our primary focus. Therefore, M-C Power has established a team to develop and bring the IMHEX fuel cell product to the market. The Team consists of M-C Power, Bechtel, Stewart \& Stevenson, and IGT.

M-C Power's leadership role includes development and manufacturing of commercial-scale IMHEX fuel cell stacks and management of the IMHEX Team. The IMHEX Commercialization Program is the complete focus of M-C Power's staff. In 1989 M-C Power established the world's first manufacturing facility dedicated to the production and testing of full-area, commercial-scale MCFC components and stacks. These facilities provide the manufacturing equipment and resources to achieve 3-MW annual production which is projected to be expanded to 10 or $12-\mathrm{MW}$ during the execution of the PDI program.

IGT, a not-for-profit R\&D organization serving the gas industry's needs for 52 years, was the inventor of the IMHEX concept. IGT's role is to provide MCFC component technology development to improve IMHEX product performance. Following development and verification in subscale tests, improvements are transferred to $\mathrm{M}-\mathrm{C}$ Power for scale-up and verification in commercial-scale IMHEX fuel cell hardware.

The Bechtel Group, established in 1898 , is a privately held corporation with annual revenues of $\$ 8$ billion and over 20,000 employees worldwide and is one of the largest engineering companies in the U.S.A. Activities include process, system and construction services for the power generation, cogeneration, petroleum, refinery, pipeline, bydro and civil construction, space, defense, mining, and metal refining industries. Bésides this extensive experience in power plant design and construction, Bechtel also has experience with the three major fuel cell technologies (phosphoric acid, solid oxide, and moiten carbonate systems). Currently, the IMHEX Commercialization Program activities are the focus of 30 staff within Bechtel Technology, one of seven operating divisions of the Bechtel Group.

Bechtel is performing the process engineering and system design efforts required to integrate the fuel cell stack into a cost-effective power plant. Their experience and expertise are vital to the identification and evaluation of cost-driven process options and balance-of-plant component selections. 
Stewart \& Stevenson Services, Inc. is a Houston-based, publicly-held company which had sales of \$812M in 1992 and employs approximately 2,900 people worldwide. They are the world's largest supplier of pre-packaged diesel and aero-derivative gas turbine power systems for commercial, industrial, power generation, and military use. The revenues from the Engineering Power Systems Group, under which the fuel cell group is organized, represent $60 \%$ of Stewart \& Stevenson's total annual sales. Stewart \& Stevenson also has a strong international market presence in military tactical vebicles, marine propulsion systems, airline ground support equipment, oilfield equipment, alternative fuel conversion systems for vehicular applications, and distributorships for a large variety of products. Stewart \& Stevenson has an established marketing, sales, distribution, and service infrastructure for their diesel and gas turbine products. This infrastructure has proven its ability to meet the customer's needs and can easily be adopted to handle the IMHEX fuel cell product.

Stewart \& Stevenson's role in the IMHEXX Team is to design and fabricate the fuel cell power plant equipment into transportable skid assemblies. Their strong presence in the packaged power generation marketplace (individual modules up to 50 MW and multi-unit systems up to $300-\mathrm{MW}$ ) provides additional market insight to the Team. Their expertise in factory assembled, unitized power generation equipment brings a capability unmatched by any other organization. They will supply the distribution, service, operation, and maintenance infrastructure required to support IMHEX commercialization.

Strategic alliances are being established with both utilities and vendors. M-C Power is negotiating exclusive distribution agreements with two utilities. These organizations will focus resources on specific territories and establish competitive energy service businesses utilizing the IMHEX fuel cell products. These alliances benefit the utilities by providing both future business opportunities and strong product influence. The IMHEX Team benefits from the direct involvement of customers in the product definition phase and additional resources to ensure successful commercialization. Similar arrangements are being discussed with other major utility companies.

The vendors for specific BOP components and manufacturing processes are also the focus of the Team's strategic alliance initiatives. For example, discussion are underway with the company that produces the IMHEX separator plates. This company is establishing fabrication facilities in the U.S. to supply heat exchangers for the heating and air conditioning marketplace. The alliance being discussed would create a U.S. based manufacturing facility which would provide cost-effective processing of the separator plates from raw material through pressing and welding to finished product. This alliance would bring additional expertise and capabilities directly into the Team to help reduce production costs and potentially introduce additional resources and commitments.

As specific balance-of-plant components are selected for the optimized MW-class product, other strategic alliances will be evaluated and developed to reduce business. risks and improve the probability of success. One example is our relationship with Ishikawajima-Harima Heavy Industries (IHI) of Japan. IHI is developing an advanced 
plate-type reformer specifically for use in MCFC power plants. This unit provides high natural gas conversion rates and integrate both the reformer catalyst and the anodeexhaust-gas combustion catalyst into a compact, cost-effective piece of equipment. M-C Power is negotiating with IHI for a license which will allow M-C Power to manufacture reformers for use in IMHEX ${ }^{\otimes}$ power plants.

Team members, Gas Research Institute (GRI), Electric Power Research Institute (EPRI), utilities, and others provide the financial resources used to cost-share government support from the U.S. Department of Energy. The IMHEX fuel cell technology represents an important new technology needed by their constituents and/or future business opportunities for their organizations. This broad-based support illustrates the importance of high-efficiency and low-enissions technologies to the power generation industry.

Sound Technologv Base. Research and development provides the foundation for the materials, components and manufacturing technologies which meet system operating requirements. Process optimization and balance-of-plant component selection and developments provide technology for integrated systems which meet customer requirements.

M-C Power's development program, including four $20 \mathrm{~kW}$ stack tests, has verified the fundamental IMHEX fuel cell technology in commercial-scale bardware. The endurance test for over 7,000 hours of operation with baseline decay of $4 \mathrm{mV} / 1000 \mathrm{hrs}$ provides the basis for life estimates. The two $250 \mathrm{~kW}$ power plant demonstrations in the 1994/1995 time frame will provide the initial verification of process and integration issues and will verify stack technology in commercial-height building blocks.

This technology base provides a sound foundation for the proposed PDI effort which is focused on MW-class power plant issues, cost-effective stack manufacturing, and component optimization and development. Successful completion of this project will provide the technology base required for commercial readiness and initial market introduction in 1999. In this time frame, the technology base which will have been established will limit the initial product to the 0.5 to $3-\mathrm{MW}$ capacity range.

Competitive Product Evolution, Demonstrations (process development units and prototype power plants to commercial products) provide the operating experiences which verify product performance, durability, and cost. Successful operations will provide the confidence needed by customers to place product orders and financial institutions to provide capital for production facilities. Operating experience also provides the Team with the information needed to establish product warranties and guarantees.

Market research has outlined the criteria for a successful product. The product must be reliable and cost-effective even during the initial stages of commercialization. To achieve a cost-effective product in the near-term the IMHEX Team must implement a responsive strategy. Some technology developers rely on manufacturing learning curve : analysis to show potential customers and investors that their products will become costeffective as sales increase. Purchasers of new technologies, on the other hand, demand a 
cost-effective product immediately. This situation creates a dilemma. Developers ask early purchasers to order large numbers of units while potential purchasers ask developers to reduce the price of early production units. In general, a few innovative users will step forward to purchase early units at elevated prices, but large numbers of orders will await competitive pricing.

The IMHEX Team could face this traditional purchaser/developer dilemma. Evolutionary technology improvements and initial production facilities could achieve market entry product prices of a few thousand dollars per kilowatt. Initial units would be purchased by innovative utilities, probably with the encouragement through incentives. With typical learning these products will be cost-effective after several hundred megawatts cumulative production.

The critical transition between sales to innovators and sales to mature product buyers is referred to as the middle market. The Team projects that this middle market will occur between the first 30 and 200 power plants delivered and is confident that the mature market prices of IMHEX power plants will be competitive. Market analysis and customer surveys have indicated that power plant price of $\$ 1500 / \mathrm{kW}$ or less are required for modular fuel cell power plants to achieve their full potential as a cost-effective alternative to other central station and distributed power generation facilities. Our studies indicate that the $\$ 1500 / \mathrm{kW}$ goal can be achieved with a mature product. The IMHEX Team believes that mature product sales will be brisk without subsidies or credits of any kind. For example, a detailed IMHEX fuel cell manufacturing cost study was completed recently. This study indicated that the fuel cell stack assembly could be produced for $\$ 250$ to $\$ 300 / \mathrm{kW}$ (excluding the stack material recovery value) in an automated production facility at levels of $200 \mathrm{MW}$ per year. A similar analysis conducted by IHI indicates that the plate-type reformer's cost target is also achievable.

To obtain sufficient orders to achieve the mature product prices discussed above, the Team must reduce the costs of both early entry and middle market power plants, and thereby avoid the dilemma. Therefore, the IMHEX Team has developed a two-pronged strategy for early and middle market cost reduction. The initial focus will be on the lowest-cost, most-durable product which can be produced in low production volumes (35 units per year), not on a product which requires high production volumes (200 to 500 units per year) to be cost-competitive. The second element of the strategy is to decrease manufacturing costs through expanded production and allow the characteristics and features to be expanded while maintaining the base-pricing structure.

In addition to evolutionary, incremental technology development efforts, high risk/high payback innovative development work will be implemented. For example, resources will be focused on developing a one-piece separator plate for the fuel cell stack, producing integrated cell packages, and eliminating stack manufacturing steps.

The Team will use innovative techniques to design a basic power plant with limited features while retaining the efficiency and emissions characteristics. The basic : power plant may have cost-saving features such as single-point on/off operation, limited heat recovery, and minimal-flexibility but it will be a low-cost, reliable product that 
meets or exceeds performance and environmental characteristics of similar capacity conventional equipment. The interactive product definition and system optinization trade-offs will result in the detailed defnition of this product which will be used to firm contingent orders from the power generation industry during 1995. Confirmed orders and down-payments will be triggered by milestones in the PDI effort. These characteristics will provide the foundation for market acceptance and a self-sufficient business.

Established Manufacturing Capability Development facilities provide the flexibility to produce technology verification and demonstration units while evaluating advanced manufacturing processes and approaches. Manufacturing and fabrication experiences also provide the foundation for conceptualizing and designing commercial production and assembly factories.

M-C Power's existing fabrication facility provides the ability to meet production needs during the verification program ( $3-4 \mathrm{MW} / \mathrm{yr}$ maximum) and has the capability to achieve maximum production rates of 10 to $12 \mathrm{MW} / \mathrm{yr}$. Advanced process and manufacturing technologies developed throughout the PDI effort and the demonstration unit fabrication experience will verify the production cost targets. Initial market entry units may utilize these existing facilities (1998 through 2000) and dedicated power plant assembly space in Stewart \& Stevenson's existing facilities.

With contingent orders for 30 to 100 units, verified production cost estimates and demonstrated product characteristics, M-C Power will raise additional capital to support a commercial-scale, stack production facility. Initially, a facility with the floor space for $200 \mathrm{MW} / \mathrm{yr}$ is envisioned with production equipment installed to achieve $35 \mathrm{MW} / \mathrm{yr}$ capacities to decrease the capital investment. The financial resources reçuired for this facility will be obtained from the present investors and/or through an expanded offering planned during the mid-1990s. With financing obtained, detailed factory design completed in 1998, and construction in 1999/2000, this facility could begin producing initial products during the year 2000 . Dedicated power plant assembly space within Stewart \& Stevenson extensive facilities will be expanded as needed to meet the baseline annual production of $35 \mathrm{MW}$.

Responsive Distribution Infrastnucture. Marketing, distribution, and service infrastructures provide mechanisms to support commercial product sales. M-C Power will lead the Team's marketing efforts through the prototype power plant demonstrations. Stewart \& Stevenson will assume the lead role in marketing, sales, and service of IMHEX power plants as early entry units are sold and deliveries begin. Their existing gas turbine and engine power generation equipment infrastructure will be expanded to handle the requirements and the commercis! IMUEEX power plant business. Stewart \& Stevenson will be assisted, in some areas, by utility companies which will act as sub-distributors. Sub-distributorship agreements are currently in place with two utilities which are providing significant funding to the IMHEX Commercialization Program. Similar agreements are being discussed with other companies. 


\section{B. Commercialization Status}

The IMIHEX Commercialization Program is a comprehensive plan of activities needed to provide the technology, development, and demonstrations required to commerciaily offer a market-entry product. The goal is to begin delivery of commercial power plants prior to the turn of the century. This program includes activities in four major areas: Technology Development, Field Verification, Manufacturing Development, and Market Development. The overall cost of this program is approximately $\$ 200 \mathrm{M}$ between 1990 and 1998, excluding market-entry support and the construction of commercial manufacturing facilities. Approximately one third of this cost has been used to support scale-up, manufacturing, and verification activities and the initial two $250-\mathrm{kW}$ demonstration units.

As indicated in Fig V.72, design, demonstration, and prototype equipment activities are progressing toward the successful achievement of our goal. The first two, 250-kW process development power plant tests are scheduled to begin operation in 1994 and 1995. Bechtel's process engineering and detailed designs for the initial unit at Unocal's Science and Technology Center in Brea, California are complete, major equipinent has been delivered, site construction has begun. M-C Power has manufactured the repeat stack components and stack assembly will begin in June. Stewart \& Stevenson is progressing on the fabrication and assembly of the mechanical skid. Unit operation will begin late in 1994. The process design for the SDG\&E unit, the second demonstration, has been selected and preliminary lay-out activities have begun. Operation of this unit is scheduled for mid 1995.

The information from these tests and the parallel design trade-off evaluations should provide the basis to proceed into prototype power plant demonstrations during the late 1990s. Initially, one pre-prototype, field-experimental unit hosted by Southern California Edison is planned for 1997 at the National Fuel Cell Research Center. This unit will be followed by three-10-six prototype power plants during the next two years. Currently, three utilities have provided letters of intent to M-C Power indicating their desires to host these power plants and several others have indicated interest in similar activities. The actual number of these prototype power plants will be based on the success of initial testing, program costs, and the amount of utility and sponsor support. A minimum of three prototype units is required to ensure sufficient verification of durability, reliability, and performance, to establish confidence in achieving capital cost targets in preparation for initial market-entry units, and to validate product warsanties and guarantees.

Included in the Commercialization Program is a smooth transition from the verification test activities into initial market-entry deliveries. To achieve this, the IMHEX Team will solicit contingent orders for market-entry units from the utilities funding our program and other ACCT members. This solicitation will occur during the 1995/1996 time frame after the product has been sufficiently defined. The contingent orders will convert to firm orders as a series of technical and business milestones are achieved during the prototype power plant testing activities. These orders will help to secure the financing required for our initial commercial manufacturing facility. 


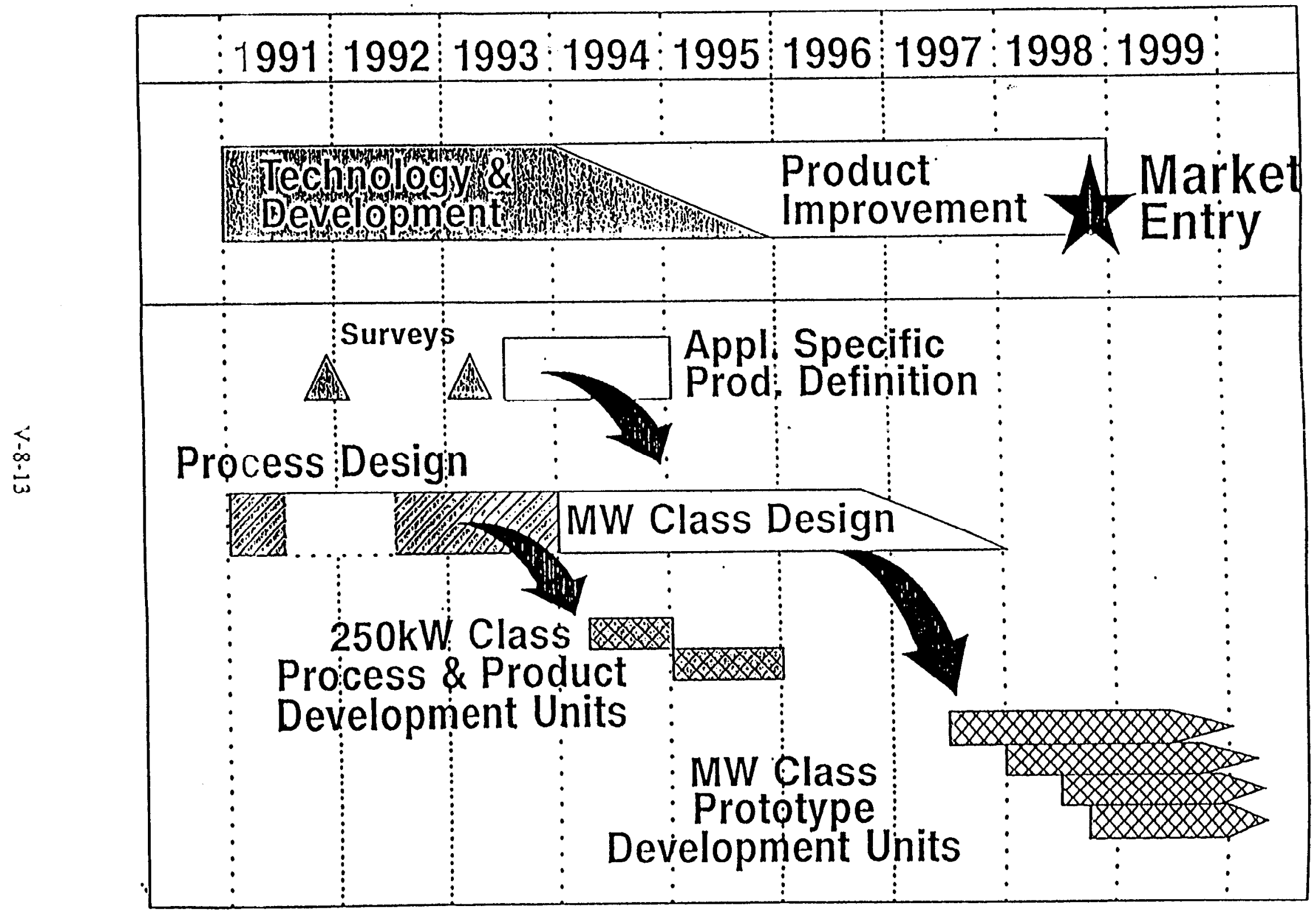

Fig. V-8.2 Overall IMHEX® Commercialization Program Activities 
As the IMHEX Tean enters the prototype power plant activities, M-C Power's current manufacturing facility will have been expanded to allow annual production of approximately 10 to 12 megawatts of IMHEX fuel cell stacks. This capacity will be sufficient for the prototype unit production, but to achieve price reductions a semiautomated facility of at least $35 \mathrm{MN}$ annual capacity is required. With sufficient contingent orders in place, M-C Power will be in a position to begin construction of this facility during the prototype verification phase of the program. This facility is scheduled to begin operation in the 2000 time frame. Financial support for the construction of this facility will be obtained through a private and/or public placement.

\section{Commercjalization Milestones}

The interactive product definition and system optinization trade-offs will result in the detailed definition of this product (price, performance, features, and warranties) which will be used to firm contingent orders from the power generation industry during 1995/1996. Confimed orders and initial down payments will be triggered by milestones in the Product Design \& Improvement (PDI) effort. These characteristics will provide the foundation for market acceptance and a self-sufficient business. Expanded production will result in decreased manufacturing costs and allow the characteristics and features to be expanded while maintaining the base-pricing siructure.

Successfully completing the proposed PDI effort is central to achieving this goal. Milestones to achieve this goal include:

- Detailed product definition during 1995;

- Firm contingent orders for units in early 1996;

- Manufacturing facility financing in 1997/1998;

- Verified product characteristics during 1997/1998;

- Initial market entry deliveries by early 1999; and

- Semi-automated production facility operation during 2000.

\section{V-8.3 Conclusion}

Commercialization of the IMHEX ${ }^{\circ}$ power plant is the IMHEX Team's sole $^{\circ}$ mission. Properly integrating the six key elements of a commercialization plan is critical to our success, our customer's confidence, our business and financial planning and our ability to achieve the financing and support required to afford product development, demonstration and market introduction. The ACCT organization continues to provide valuable input into our product definition activities and our understanding of marketplace requirements. The IMHEX Team members who are focusing on the process and balance-of-plant issues have allowed M-C Power to concentrate on the stack design and manufacturing issues. Other partnerships are providing the foundation for a distribution network and the establishment of strategic alliances with vendors. Advanced MCFC technologies and the verification of commercial-scale hardware is providing a sound technology base for commercial products. The incremental approach to product development (250-kW demonstrations at Unocal and SDG\&E to MW-class pre-prototype 
and prototype power plants) provide a cost-effective path to the development of a competitive product for market entry. Manufacturing processes developed on commercial scale equipment with production capabilities sufficient for demonstration phases allow the smooth transition from the development phase into commercial market introduction. Developing a commercialization partnership with a company, such as Stewart \& Stevenson, that has existing marketing, sales, distribution, and service infrastructure for power generation equipment will ensure that the introduction of the IMHEX ${ }^{\otimes}$ power plant will not be delayed by the need to develop this infrastructure.

The transition from technology development to power plant demonstration is proceeding according to the Team's overall commercialization plans. Future design and manufacturing efforts will be targeted to produce and demonstrate MW-class power plants, beginning with the pre-prototype unit. These MW-class demonstrations will lead the Team toward its goal of producing cost-competitive IMHEX ${ }^{8}$ power plants for distributed generation applications. The Team is confident that this step-wise demonstration approach will result in early market entry of domestically produced IMHEX ${ }^{\otimes}$ power plants before the beginnir.g of the $21^{\text {st }}$ Century. 



\section{V-9. The Westinghouse View of SOFC-System Commercialization (Tubular SOFCs) $t$}

The key sorc attributes that make it an attractive power generation techrology are high efficiency, high exhaust temperature, clean emissions, siting flexibility, low maintenance, and modularity. These attributes can be cescriber as follows:

- The sozC is inherertly a high effieiency converter of fuel chemical energy into electrical energy which will contribute to fuel economy and the conservation of fossil fuels. With its high exhaust temperature, the SCFC provides an excellent basis.for state-of-the-art combined heat/power and combined cycle power plants that will contribute further to fossilfuel econony.

- The SOFC exhaust contains low concentrations of nitrogen oxides, virtually no sulfur oxides, and carbon dioxice emissions less than competing technologies as a result of the higher efficiency. With this elean-emission characteristic, the technology will reacily neet increasingly stringent emissions standards.

- With its clean emissions and inherently ouiet, vibration-free operation, the sorC power plant will permit siting at locations previousiy not consicered feasible with competing conventional technologies.

- The SOFC operation requires no corrosive liguids nor are iiguics reguized for cooling. These characteristics will contribute to the potential of low-maintenance operation of SOFC power plants.

$\therefore$ Sorc generators will be manufactured in mocules of stancard ratings thet will be readily available. foditional power can therefore be adied ouickly, and replacement modules will be available wher they are reeced. Thus, the SOFC approach will minimize rew-construction lead times and maintenance down times.

\section{V-9.1 SOFC DEVELOPMENT STATUS (TUBULAR SOFCs)}

westinghouse hes procueed and operated for extended periods over 4,500 cells. Lifetine has been an area of concern and it is the subject of ongoing development. Two cells currently on test have exceeded five years of power operation (Iigure $V-8-1$ ).

\footnotetext{
Submitued by Walter J. Dollard
} 
Westinghouse has supplied several soFC systems for user evaluations. In 1986, the Tensessee Valley Authority (TVA) operated for 1760 hours a 400 watt SOFC system, the module for which used 24 cells of $30 \mathrm{~cm}$ active lengths. Osaka Gas and Tokyo Gas operated $3 \mathrm{~kW}$ SOFC systems in 1987. Each $3 \mathrm{~kW}$ module incorporated 144 cells of $36 \mathrm{~cm}$ active lengths. A.t Osaka Gas, two nodules were used. The first, a training module, operated for 2900 hours before it was replaced on a preplanned schecule with a second module which was operated for 3600 hours. At Tokyo Gas, the $3 \mathrm{kw}$ system was operated for 4900 hours. The TVA:unit and the $3 \mathrm{~kW}$ units for Tokyo Gas and osaka Gas used hydrogen and carbor monoxide as fuel. In 1992 hestinghouse celivered to The UTILITIEs, a consortiun of The Kansai Electric Pover Company, the Tokyo Gas Company, and the Osaka Gas company, a ratural gas fleled sofC systen of nominally 25 kie capacity (40 kive peak) employing 1152 cells of $50 \mathrm{~cm}$ active lengths in two modules. Testing was initiated in February 1992. Module A operated for 2529 hours and Hodule 3 operated for 1576 hours. Module 3 was repaired and successfully operated for 7000 hours upon which time the test was concluced. A similar system built for the consortiun of the Tokyo Gas company and the osaka Gas company, but with cogeneration eapability, was operated for approximately 900 hours. The generation of over $300.000 \mathrm{~kW}-\mathrm{hr}$ of electricity by westinghouse sorc systems in the past several years provides testimony to the technical viability of the tubular sofC technology.

To enhance economic viability, westinghouse is working to recuce the cost of cell and module manufacture and to increase the power output per cell. The commitment to cost reduction is evidenced by the investment of hestinghouse cepital funds in a Pre-pilot Kanufacturing Facility (PPIS). The objective of this facility is the development of cell and module manufacturing techniques. In integral part of this PPIF process is the masufacturing of field unit systems.

In field units manufactured to date, tise construction of inoividual tubular SCFCs was based ch a porcus support tube (EST), and to increase power output per unit cell length, westinghouse has progressively reduced the PST thickness. The celis in the $3 \mathrm{kw}$ SOFC systems used a $2 \mathrm{~mm}$ thick porous support tube, and the cells 
manufactured at the p?: for the 25 kwe class systems use a thin-wall porous support tube, $1.2 \mathrm{~mm}$ thick. Now in the initial stage of procuction are cells hisich elininate the pozous support tube entirely by using the ail electroce as, the suppert stricture. This evolution in cell design is cepicted in Figure $V-8-2$. The performance of the airelectrode-supported (aIs) cell is contrasted with that of thick wall and thin wall porous support tube celis in Figure V-8-3. Westinghouse has produced $k$ Es cells ranging in active length fxom $30 \mathrm{~cm}=0100 \mathrm{~cm}$, and zecently, $168 \mathrm{~cm}$ cells. presertly, Aas cells are the focus of the westinghouse cell eevelopment and testing progran, and will be used in the 100 kive systems. The successful developinent of longer cells, along with the developient of the i=s cell, results in a sevenfold increase in power per cell gelative to the technology used in the 3 kit sort systens.

\section{V-9.2. COMMERCIALIZATION PLAN OF TUBLLAR SOFCs}

The basic SOFC technology has been floven to be technicaliy and environnentaliy attractive, and the next step is to make sozc generators comercially attractive. Pre-pilot scale production has by definition

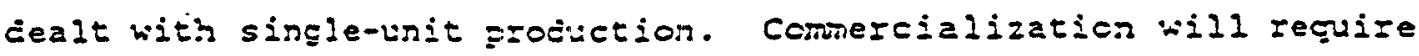
modules that can be mass produced. We aze ceveloping standard mocule designs with mass producticn in mind, cesigning processes fer cell production that lend themselves to mass protuction, and we plan to stancardize the non-cell components with the sane objective.

Development programs are also incerway to extend cell life, improve power censity, and eliminate manufacturing steps.

The kiestinghouse comezcialization glan for sCFC technology is sumarized in Taile $\mathrm{V}-8-1$. The basis of the plan consists of fimming up our manufacturiag technigues and proving the curability of sorc mocules and systems through the testing of field units by utilities and other potential custcmers. Through costinued cell asd mocule manufacture and field unit operation, progress cown the cost lecrning eurve will be made, ard ihe soEC technology wili be groven. 
Table V-9.1. The westinghouse Comercialization Program.

\begin{tabular}{|c|c|c|}
\hline \multicolumn{3}{|c|}{ zxpezisedtal Uaits } \\
\hline $25 \mathrm{~kW}$ & KEPCO/Tokyo Gas/Osaka Gas & 1992 \\
\hline $25 \mathrm{~kW}$ & Tokyo Gas/Osaka Gas & 1992 \\
\hline $20 \mathrm{~kW}$ & Southern California Edison & 1994 \\
\hline \multicolumn{3}{|c|}{ zroof-01-concept Da1tn } \\
\hline $100-200 \mathrm{~kW}$ & $2-3$ Units & $1996 / 1997$ \\
\hline $1-2$ IN & 1-3 Units & $1997 / 1998$ \\
\hline \multicolumn{3}{|c|}{ Pre-comercial Units } \\
\hline $50-100 \mathrm{KWW}$ & single/Multiple orcers & 1998 \\
\hline
\end{tabular}

our experience with soFC systems has been good. Westinghouse is building systems now that will operate for extended periods of time to establish product lifetime and reliability. Future units will be in the multi-hundred $\mathrm{kW}$ size range. The demonstration of a Min-class sofC module, which will be the forerunner building block for distributed, repowering, and central station power plant epplications is planned for the late 1390 's. The $100 \mathrm{kw}$ field units will contain celis that are prototypes of the cells that will be used in the Mw class mocule.

The commercialization plan also includes the design and fabrication of a manufacturing plant. However, before the plant can be cesigred and built, more work is reeded to finalize the processes to be used in mass producing cells and generators. Therefore, westinghouse has now comitted to the second pre-pilot manufacturing plant for tire SOFC technology which is currentiy being assembled on the site of the hestinghouse science \& Technology Center. This second facility will represent a five-fold initial increase of capacity as conpared to tre existing Pre-Pilot Plant and will include space for even further exparsion.

The productica and testing of the MW-class soFC module is extremely important to the progran. A single reganiat size demonstration is estimzted to cost $\$ 50,000,000$. In the past, electric and gas utility management bave been willing to support such demonstrations as they were needed for what we now call conventicnal:technology. However. with the massive changes now taking place in the 
utility marketplace, the increased influence of regulatory and consumer groups, and the guestion of just who will own the electric generation facilities, funding of these cemonstrations is more difficult than ever. In order for the sorc technology to be a future option for the utilities and others, everyone must share in the cost of the demonstrations; i.e. DOE, utility and utility agencies, Westinghouse, and others.

westinghouse is in the process o: icentifying potential participants for the demonstration program. 
Figure V-9.1

\section{SOFC Development Progress (Tubular SOFCs): Cell Stability.}

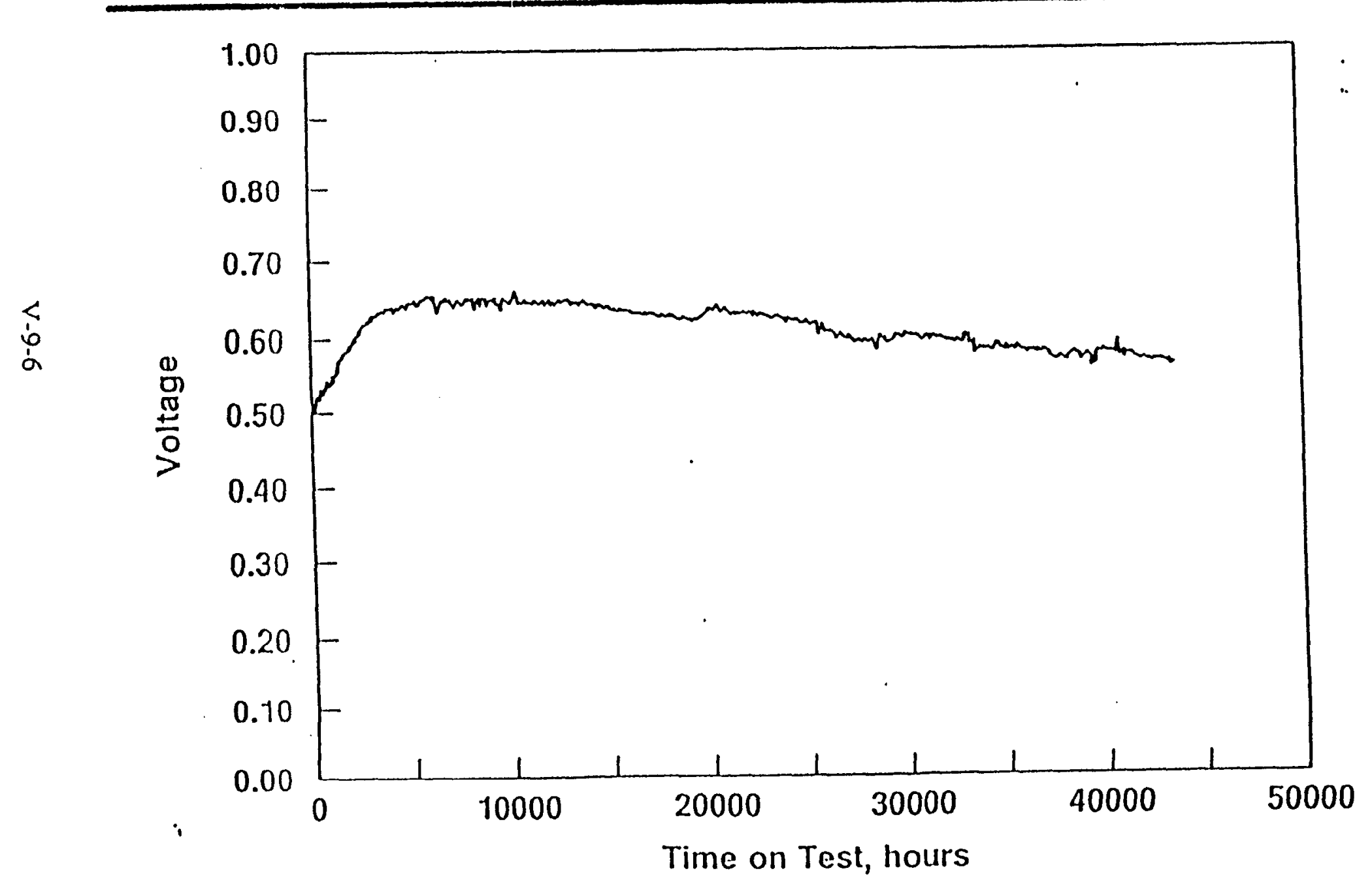




\section{Tubular \\ Solid Oxide Fuel Cell - Evolution of Cell,Design.}

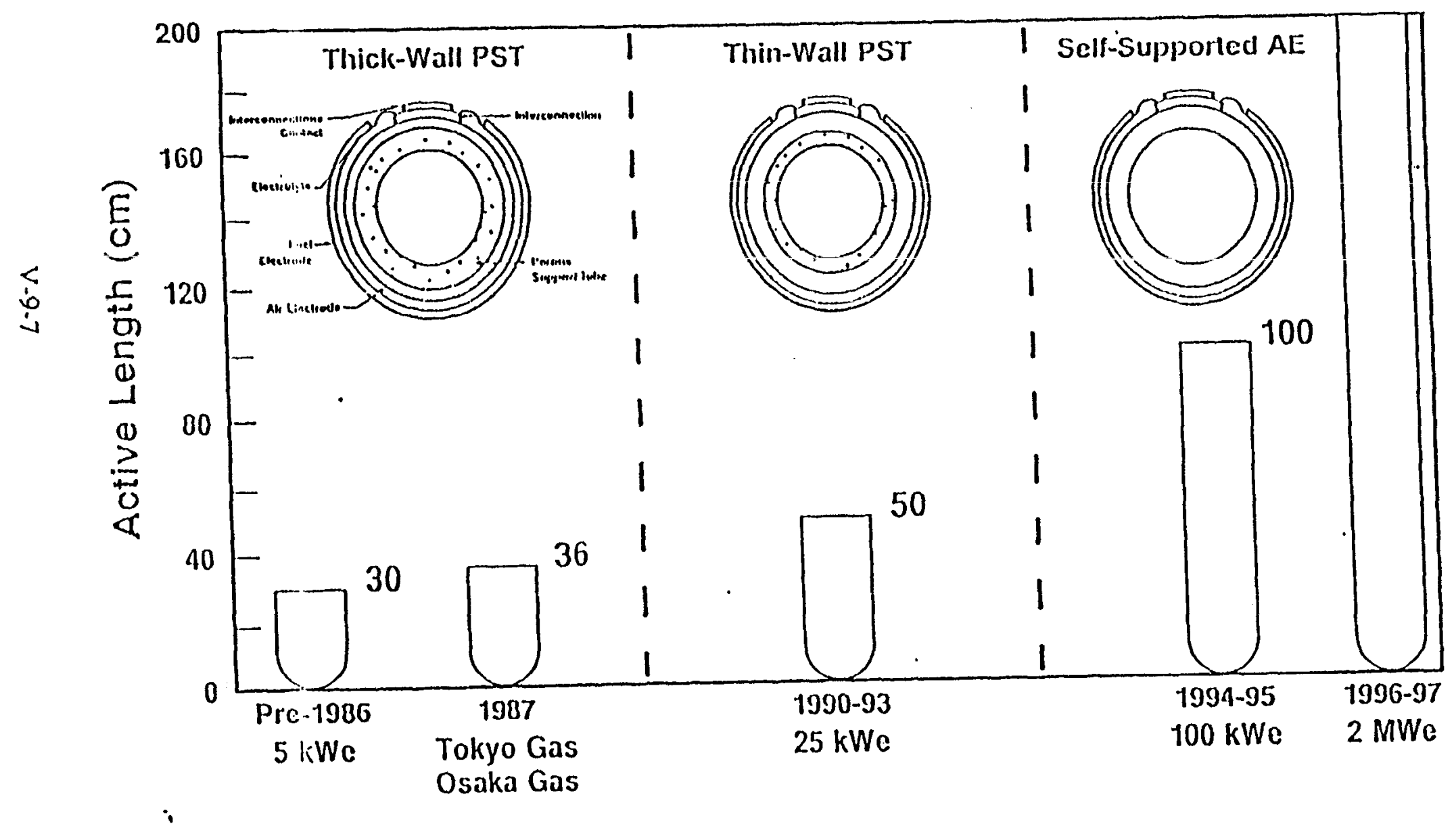


SOFC Development Progress lar:SOFCs): Increased Power Density.

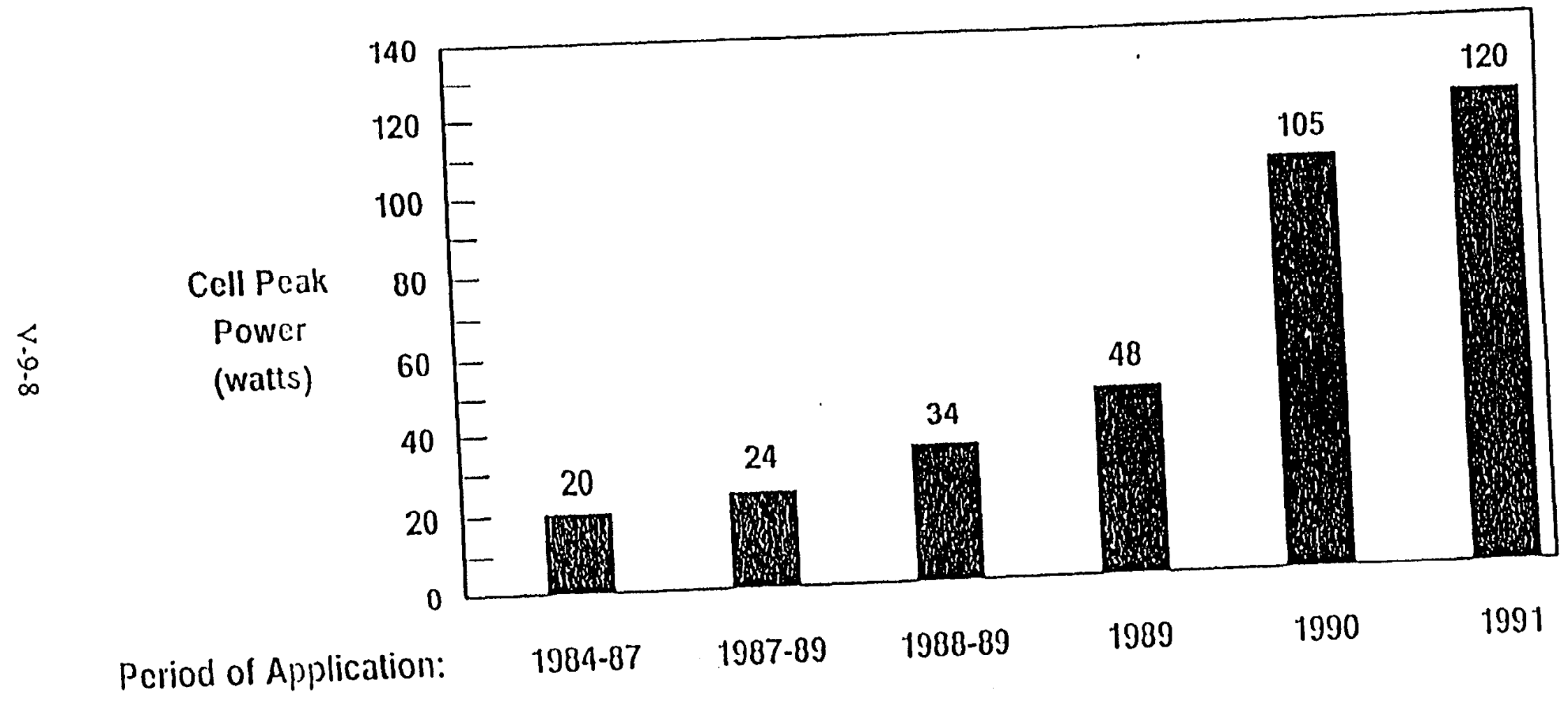




V-10. ZIEK ADVANCED IIRNAR RIIQ SOFC
EORICIZNT AND COSM-EFFECTIVI
OTIIITY POWER PIANTS

\section{V-10.1 RRODOCI DEZINITION}

ztek's Planar solid oxide zuel cell (SOFC) system, an advanced "chird generation systen," has exceptional potential for utility scale electric power generation because of: simplicity of components construction, capability for low-cost masufacturing, efficient recovery of very high quality by-product heat (1000\% $\mathrm{C}$ ), and system-integration simplicity. The potential to offer high system efficiency together with simple system integration is derived from the Radiant Thermal Integration (RTIO), a unioue feature in the ztek hovanced planar sofC design, not shared by any other existing SOFC OI MCFC options. Utility applicetions of ztek's scale-up technology, Planaz RTIQ SOIC, are varied and include multi-megawet central power plants, Iepowering existing power plants (i.e. 30Nw to 100Nw), and dispersed generation units (IWW to 30Nw capacity) that are being considered by electric Ltilities. The operational flexibility of the ztek's planar sosc system under a variety of possible pressurized conditions provides aditional advantages in terms of efficiency and cost in a direct integration with coal gasifier and gas/steam turbines bottoming plant.

\section{V-10.2 A FUEI CEII TECENOLOGY READY IOR ACCELERATED DEVEIOZXENI AND COYMERCIAIIZATION}

'ztek corporation welcomes the opportunity to provide information on the techrology and product plansing for the Advanced ztek so:C. It is recognized that as a thild generation Euel-cell technolosy justifiable for an accelerated development, demonstration and comercialization path. there has been less publicity and information available compared to other technologies. Ke, herein, particularly discuss performance Eeatures that provice signizicant differences and jenezits compared to what has been projecred and observed for Molten Carbonate and mubular solid oxide, and other planar sozc concepts. The contrasts will focus upon potential for low-cost manufacturing, simplified balance of plant, and high efficiency and low cost of integrated utility power-plant systems.

*Subitcted by Mcbael Esu. 
Ztek Advanced Planar SOFC holds significant promise for early commercialization for utility applications, even though other technologies would appear to be closer to larger capacity fuel cell demonstrations at this time. Significant factors include using a standardized $25 \mathrm{kw}$ utility module element as a building block for scale up and packaging of $\mathrm{MW}$ scale power plants and a unique Radiant Thermal Integration (RTIQ) feature which simplifies thermal managenent, balance of plant and system integration. We have an existing production capacity of $8 \mathrm{MH} / \mathrm{year}$ with ztek and a network of subcontractors with established fabrication equipment.

our emphasis is that this Planar sOFC technology is attractive for Mw-scale utility applications considering dispersed generation, power generation, and IGFC. These Mi-scale applications are being pursued by faithfuliy executing the basic modularity characteristics of fuel cells, allowing truly flexible system definitions. This ensures timely response to individual utility's definition of requirements based on changing market trends.

\section{BACKGRODND - TRADITIONAI IAIANCB OF FIANT CONSIDERATIONS}

is the fuel-cell industry is approaching product maturity, meeting cost and efficient requirements, it is important to recognize that the fuel cell as a power plant, rather than a storage battery, is entering a highly competitive utility industry. It must compete on an economic basis with wide options for power generation. Aoaressive oursuit of highlv integrated sustems, especiallv as a third oeneration techooloov, can overcome . Slow rechneloov convercence and hioh product cost associated with compartmentalized development efforts experienced in the early generations of technology development.

The existing PAFC, PEMFC, MCFC, and other SOFC development approaches can be characterized as "traditional". since they focus on the assembly of the following three separate and

compartmentalized subsystems:

1. the fuel cell stack subsystem

2. the fuel processing subsystem, and

3. the themal menagement subsystem.

The fuel processing subsystem and the thermal management subsystem are often referzed to as Balance-of-plant. It is increasingly recognized that these subsystems can significantly contribute to system complexity and cost. The Balance-of-plant components dominate the builiup of overail system cost, tipping the scales on econonic competitiveness.

The "traditional: method for fuel cell thermal management has been to force a licuid or excess gaseous coolant stream through the fuel-cell assenbly. cooling water has been used for ambient temperature devices. Air (oxidant) has been applied for higher temperature fuel ceils. The coolant enters the fuel cell assembly 
at a temperature near the requized electrolyte operating temperature and carries off the themmal energy by its sensible heat capacity. The volume flow of coolant reguired for this method is inversely related to its allowed temperature rise, which is determined either by the limited range of the electrochemical operation of the electrolyte, or in the case of fuel cells with ceramic components, by the constraints associated with thermal stress.

\section{rraditional Thermal yanagement considerations}

The "trabitional" method for fuel-cell thermal management has been to force a liquid or excess gaseous coolant stream through the fuel cell assembly. Cooling tater has been used for ambient temperature devices. Ais (oxident) has been epplied for higher temperature fuel celis. The coolant enters the fuel-cell assembly at a temperature sear the reguired electrolyte operating temperature and carries off the thermal energy by its sensible heat capacity. The volume flow of coolant required for this method is inversely related to its allowed temperature rise, which is determined either by the limited range of the electrochemical operation of the electrolyte. or, in the case of fuel cells with ceranic components, by the constraints associated with thermal stress.

Usually, these limitations on temperature rise result in coolent flow rates much higher than what would be required for the electrochemical reaction alone. Since these large flow guantities must be preheated, a dedicated reactant thermal management subsystem comprising equipment for preheating, pumping and processing the excessive air flow is required. Additionally. energy conservation consideraticns make it necessary to process this large flow of the coolant frocessed through regenerators. These components characterized by low thermal process rates substantially increase the Balance-of-plant cost and in fact dominate the system cost. 


\section{V-10.3 zTEK INTEGRATED SOLUTION - ADVANCED PLANAR RTIO SOFC}

Taking advantages of the technology characteristics and the vantage point available to the "third generation" fuel cell development, ztek is aggressively pursuing a highly integrated Planar SOFC to realize system simplicity and energy efficient integration. The overail development cost and risk are expected to be lower than those encountered in traditional approaches, because of the coordinated techrology strategy adopted at the onset of the ztek technology development. ztek's systems integration perspective has also benefited from observations of the system difficulties encountered during the development of other fuel-cell technologies, including the first generation pafc and. in the recent years, the second generation MCFC. ztek considers that the integrated fuel-cell technology represents the necessary approach for accelerated development of fuel cell systens that can meet stringent economic and efficiency requirements.

\section{A. Technology Advanioges}

The ztek Advanced Planar RTIB SOFC approach has been formulated to incorporate the fuel-cell stack, fuel processing, and thermal management in an integrated system. Some of the advartages offered by this approach include:

- Simplified thermal mazagezeat

The ztek Planal so:c with a Radiant Thermal Integration feature offers attractive options to achieve an economical and simple thermal management subsystem. The resulting benefit is the drastic reduction of beat-transfer surfaces compared to other technolooies - to less than $1 / 10$ of the fuel cell active surface area. lother fuel cell technologies require heat-transfer surfaces which are more than 10 times the fuel cell active surface area). Radiant Thermal Integration, in effective method of heat recovery from the fuel-cell stack, is a special feature only available in the ztek Advanced planar SOEC and is not a generic feature of other high or medium temperature fuel celis. The ztek RTIB feature relares to the inherent design and operation of the ztek Advanced ?lenar soFC with internal manifolding and internal direct heat exchanging. In contrast, with tradicional fuel-cell technologies and approaches, the Balance-of-plant components associated with themmal management have been shows to dominate the buildup of systen cost and compiexizy.

- \#1gh system efficiency

The Ztek Advanced Planar SOFC has high system efficiercies when operating on a stand-alone basis, i.e. electrical production alone. The ztek SOFC efficiencies are substantially higher than other techsologies when compared on 
a system basis of optimal internal thermal integration with bottoming cycle devices, approaching $70 \%$. Flg: $\mathrm{V}-9-1$ shows fuel-cell-based power-system efficiency versus operation temperature of various fuel-cell types.

The RTIQ Planar SOFC Can be viewed as a $1000^{\circ} \mathrm{C}$ heat source serving as a clean burner (i.e. a "glow bar" at $1000^{\circ} \mathrm{C}$ ), with the bottoming system performing thermal processing function for the SOFC. Important from a system standpoint, the radiative thermal integration permits mechanical decoupling of the electrochemical subsystem from the thernodynamic subsystem and facilitates independent performance optimization. This leads te a thoroudh modularization ef the fuel-cell assemblv with its reactant processor and control. and sinole infegration interfaces with the centralized bottoming cucle the overall effects are high combined efficiency, low overall system cost cue to complementary components utilization, flexibility in integration and ease of maintenance.

- compact, lightweight, and small footpzint This advantage is the direct result of the ztek stack geometric design, manifolding and thermal integration.

- Mechanical Iuggedness and transportability

The ztek Advanced Planar sogc has a robust design since it utilizes the composite stack constuction, in wich the ceramic zirconia electrolyte plates are supported and cushioned between the interconnector plates. This makes the system capable of withstanding impacts or vibrations that could be encountered during transportation and shipment.

- Low cost maduEacturizg

The configuration, materials selections, and fabrication procedures of the ztek Planar SOFC stacks provide for low manufacturing cost. The scalability potential offered by building up repeating sections and modules also enhances manufacturing and systen costs.

- Ability to produce and capturechexhaust stream of pure $\mathrm{CO}_{2}$ The ease with which a pure $\mathrm{CO}_{2}$ exhaust strean could be produced has significant inplications in light of increasing concerns over greeniouse gases and giobal riarming.

- compatible vith pressurized operation

The Planar sozc Technology is fully compatible with operation at ambient or elevated pressure conditions. Specifically:the planar cell is structurally compatible with operating at

$$
v-0.5
$$


high pressure and tolerant to a finite pressure difference between opposing reactants due to the mechanical design. materials, and the small free span chosen for the ceranic electrolyte supports. This feature provides a benefir in terms of packaging and module integration. The pressurized operation of the Planar SOFC with its internal manifolding and small-sized piping will allow larger capaciry modules to be integrated in the fuel cell subsystem of the power plant.

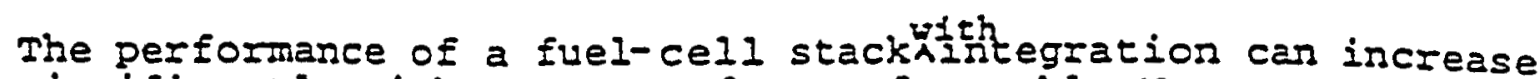
significantly with pressure due to favorable Nernst potential and enhanced flow uniformity at high pressure, resulting in higher power density. This further enhances the compactness and cost advantage in consideration of the fuel cell stack ard the pressure vessel design. By operating the planar sofC at a pressurized condition, in conjunction with a coal

- Gasifier as the fuel supply and with a gas turbine in direct

flow integration as a bottoming device, a system of high efficiency and superior cost performance can be realized compared to other alternatives for IGCC.

- Eigh tolerance to sulfur and otber contaminants

The ztek Advanced Planar sozC offers substantial advantages and flexibility regarding significant increases in tolerance to sulfur and other trace contaminants. This capability is made possible by the geometrical configuration. electrical properties, and the material options for components in the fuel cell stack. The planaI sofC design has the potential for direct hookup with the output strean of coal gasification systems considering the high temperature, high pressure and sulfur content of state-of-the-art systems.

\section{B. Summan Technical Descripion}

The ztek approach to the Planar sofC of internal manifolding, thermally conductive interconsectors, and appropriate plate size selection leads to the unique capability for Radiant Thermal Integration. The ztek Planar sofC techrology, trade ramed planar RTIQ SOFC, is constructed of thin plates of zirconia electrolyte alternately arranged with electrical interconnectoz plates, Fig. V-9.2 2 . This concept has internal manifolding, internal gas passages through the plates, which provides the oxidizer and fuel supplies, and permits spent gases to exhaust. Fig.v-9.3, Progression of zirconverter Integration schemetically shows the scale-up from the stack to a utility module element, then to a typical fuel cell artay system mocule, which is subsequently integrated with a cooling array contaning the working mediun for heat rencial or recovery through the Radiant Thermal Integration.

A $25 \mathrm{~kW}$ utility module element is ztek's intended building block for the utility use of zirconia fuel cells. Systems of. mulei-megawatt capacity can be obtained by packaging the modules in 2-dimensional or 3-dimensional arrays. 
A TVA/ 1992. This program involves functional testing of ztek's Advancé Planar SOFC stack and design scale-up for utility power generation applications. The emphasis is on the engineering design of the utility modules which will be the building blocks for multimegawatt power plants, and evaluating the haroware implementation of a Radiant Thermal Integration feature.

Foster wheeler Development Corporation is participating in this project in an effore that adoresses the integration of the SOEC system with the bottoming plant: the effects of operating pressure and components sizing; and conceptual formulation for overall plant construction based upon Radiant Thermal Integration. ztek is providing descriptive and technical material on fuel cell design, system integration approaches, interfaces, materials, etc. for technical assessment and amplification by foster theeler. Current plans are for Foster wheeler to address two study cases:

1. Baseline Case A - Fuel Cell/stean Bottoming Hybrid System $(50-200 \mathrm{MW})$, and

2. Baseline Case B - Fuel cell/Gas Turbine Botroming aybrid System $(2-50 \mathrm{~N}$ ).

Foster wheeler efforts adiresses system process flow studies, efficiency calculations, and system cost estimates.

\section{V-10.4 COMMERCIAI POHZR-2IANT COST}

We are proceeding with detailed system cost estimates with the assistance of zoster wheeler. Our work to date indicates that the installed cost estimates to be low compared to other techrologies, both molter carborate and solid oxide. 3ackground information on fuel cell stack and system costs are provided below for reference.

The configuration, materials selections, and fabrication procedures of the Planir SOFC stacks (trade named zirconverter(a) provide for low manufacturing cost. Detailed study of the production costs hes been conducted. The direct material cost for the zirconverter(a) has been estimeted to be less than $\$ 100 / \mathrm{kW}$. The fabrication and essembly cost is estimated to be about $\$ 100 / \mathrm{kW}$. bringing the total estimated direct cost (material and labor) of the assembled fuel cell stack to about $\$ 200 / \mathrm{kW}$. There is also low cost potential for integrated $z$ irconverter(B sofC power generation systems, derived from the simple radiative thermal interface for integration, tre ilexibilicy in acapting commerciaiiy availabie bottoming system options, and the compact fuel cell loop design. 


\section{V-10.5 PRODOCT DSVELORHENT STRATEGY}

ztek's product development strategy follows through the basic mocular characteristics, leading to flexible product definition for utilities. This strategy formulation is based upon:

- The modularized packaging, including reactants processor/ control with tie utility module, as the flexible building blocks for scale up to mw level systems.

- The berefit of learning from prior fuel cell programs, working with utilities and responding to their needs and their customers' needs and avoiding prematurely pushing a product upon the utility industry by. Following the evolving process of curzent utility assessment of benefits and suitable configurations for dispersed generation, repowering, and central power generation.

- The attzaction of the long tern potential of the planar sorc $\therefore$ for central power systems above $20 \mathrm{MW}$ and for repowering through establishing customer satisfaction and confidence by iritial demonstrations in the $200 \mathrm{~kW}$ to $2.5 \mathrm{~mW}$ range.

The technology milestones planned for the ztek Advanced sOFC in utility epplications lead to a $2.5 \mathrm{mw}$ system demonstration in the 1998-99 inme irame.

\section{V-10.6 COKHERCIALIZATION RLANS}

\section{V-10.6.I RARKET - ENTRY PIALS}

We plan to enter the commercial market with an integrated system which offers urilities the benefits of high efficiency, favorable environnental performance, low capital and operating costs. This integrated system is described as a hybrid system with a solid oxide fuel cell system radiatively coupled with a bottoming steam or gas turbine. The techrical and financial basis is supported by the viable integration with the RTIQ feature and the resulting off-the-shelf balance of plant.

Although the hybrid system is believed to be a preferred system configuration. the sOFC system on a stand alone operating basis is also atrzactive and can be made available to customers desiring such a system or wishing to have comparative operating demonstrations with other technologies.

Case studies of techrical and perfomence characteristics along with process flow diagrams are being established with the
assistarce of Foster wheeler.

Since Planar sozc is a thira generation technology, operattng data is curfently more limited in comparison to second generation fuel cell configurations. However, the performance and rrends 
shown in existing data, the simplicity of system integration, and cost and efficiency projections indicate tremendous potential for performance and rapid convergence for commercialization in a broad range of utility scale power plants.

The development and tine frame for commercialization of the planar sofC are consistent with the planning time frame of electric utilities, and are competirive with other technologies regarding schedules for implenenting power plant scaled systems,

The basic modularitv characteristic of the fuel cell. imolemented cicorousiv in the ztek desion. orovides the flexibility in strategic plansing for product development and introduction. The intent is to have a technology which can respond to utility needs as determined by the utility and adapt to various applicarions, is well as changes, in the urility's business environment.

Although the ztek technology can satisfy a broad range of applications, including multi-megawatt utility power plants and repowering, it is recognized that many utilities may wish to demonstrate smaller units initially, i.e. 2Mw to obtain operating experience and establish confidence. The flexible integration approach followed by ztek will be valuable to utilities who would like to commit to a fuel cell technology, but would like to have the freedom to define the precise configuration at a time when. firmer market data is available.

\section{V-10.6.2 DTIIITY FARTICIPATION}

As mentioned above, ztek is currently involved in a TVA/EPRI collaboration project which was initiated in september 1992. This program involves functional testing of ztek's Advanced planar sofC stack and design scale-up for utility power generation applications. The emphasis is on the engineering design of the utility module elenents which will be the building blocks for multi-megawate power plants, and evaluating the hardware implementation of a Radiant thermal Integration (RTIB) feature. The overall objectives of the program are:

- Design and construct a proof-of-concept Advanced planar sozc rodule which is scalable for utility applications.

- Assess operational procedures and performance using a Eully instrumented utiliry module assembly.

The progran is devoted to a $25 \mathrm{kir}$ urility mocule element foI utility demonstration. This test configuration includes three subassemblies:

1. As SOFC utility mocule subassembly,

2. A reactant and operation control subassembly, and

3. An associated power conditjoning subassembly (optional). 
The SOFC utility module subassembly, as shown in Fig. V-9.4, consists of an array of the SOFC utility module elements, the reactants regenerator heat exchanger, the RTI\& coolant circuit, the reactant distribution piping, the power connections and the required thermal insulation. The test configuration consists of as active utility module element of $25 \mathrm{kw}$ capacity, plus two repeating (thermal simulation) module elements to provide the radiant thermal integration environment. Within the geometric confire, this assembly could be upgraded to provide a $75 \mathrm{kw}$ capacity by replacing the two themal simulation elements with two active $25 \mathrm{~kW}$ SOFC module elements.

Additional utility participation is plansed with an exparded Fuel Cell Development Consortium and a Fuel Cell Commercialization consortium, as a conseouence of an ongoing dialogue being maintained by ztek with various electric and combined electric/gas utilities. A Utility ruel Cell development consortiun is being orgarized to ensure that our developments are consistent with industry needs and to maintain communication among them members. In addition to providing guidance during the progran efforts, members of this consortiun will participate in the demonstration efforts, leading to commercialization of the ztek sofc technology. The fuel cell comercialization consortium is also currently being developed. It would entail a group and buyers and participants motivated to promote the commercialization of the ztek. Planar SOFC. There would be coordination among participants, hosts for demonstrations, and buyers of eariy production units. Financial incentives would be established, including discounts or royalty payments, linking the differences that could exist between the cost of early production units and commercial units. 


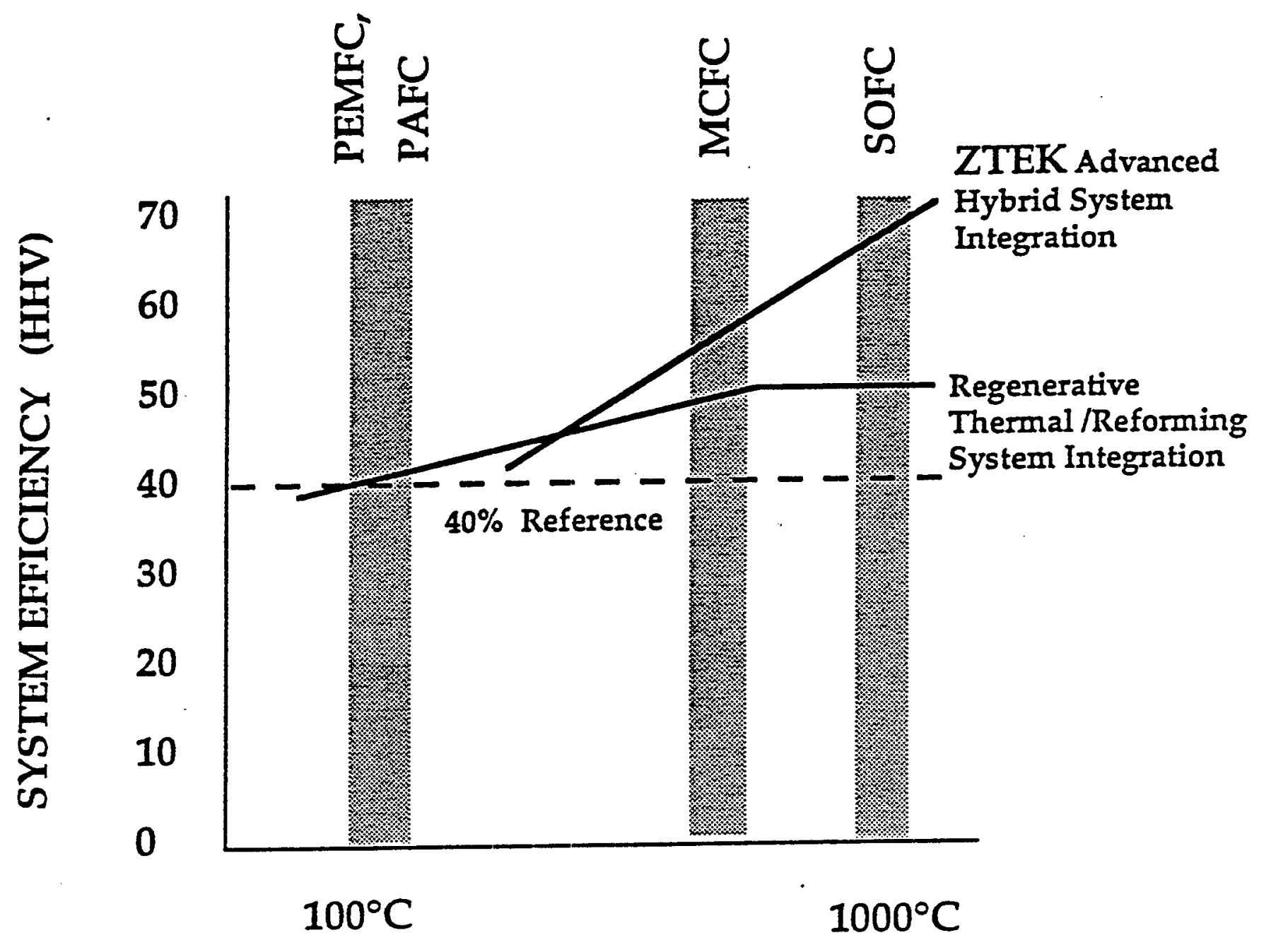

FUEL CELL OPERATION TEMPERATURE

Figure V-10.1. Fuel Cell System Efficiency vs Operation Temperature 


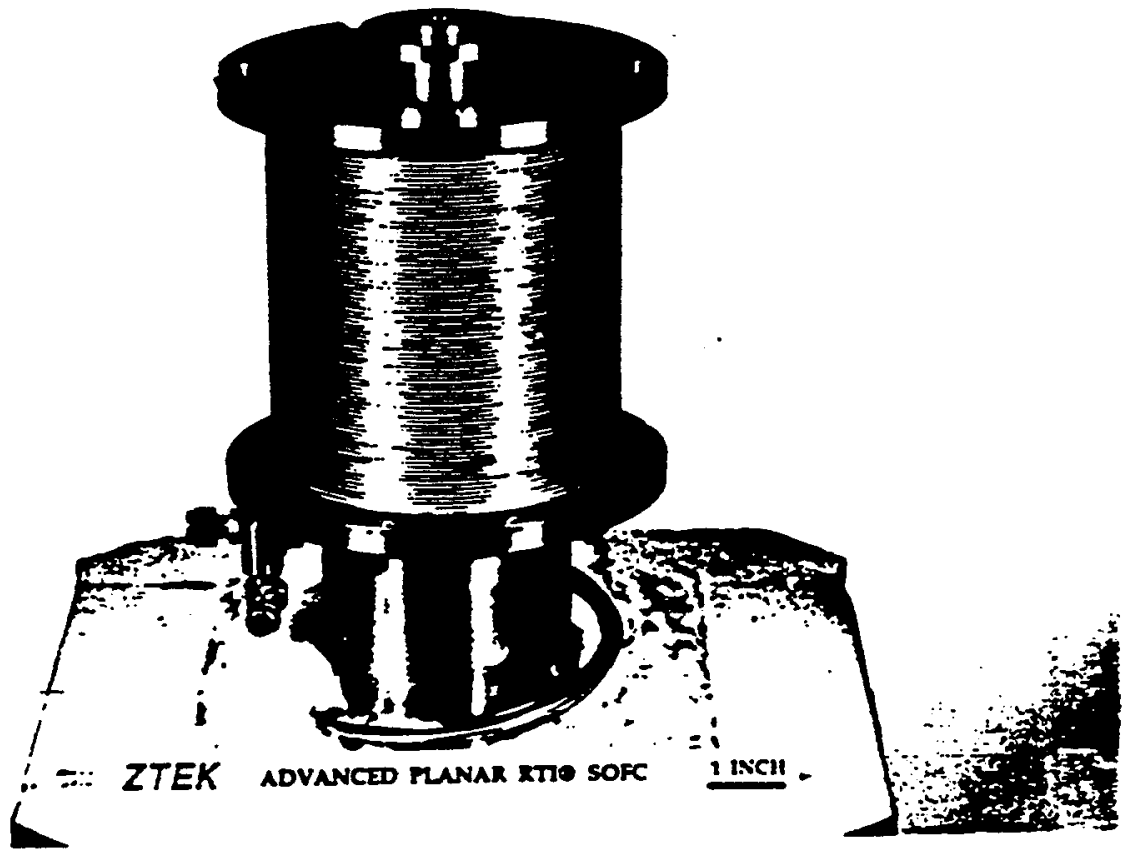

Figure V-10.2. Ztek Advanced Planar SOFC Stack 


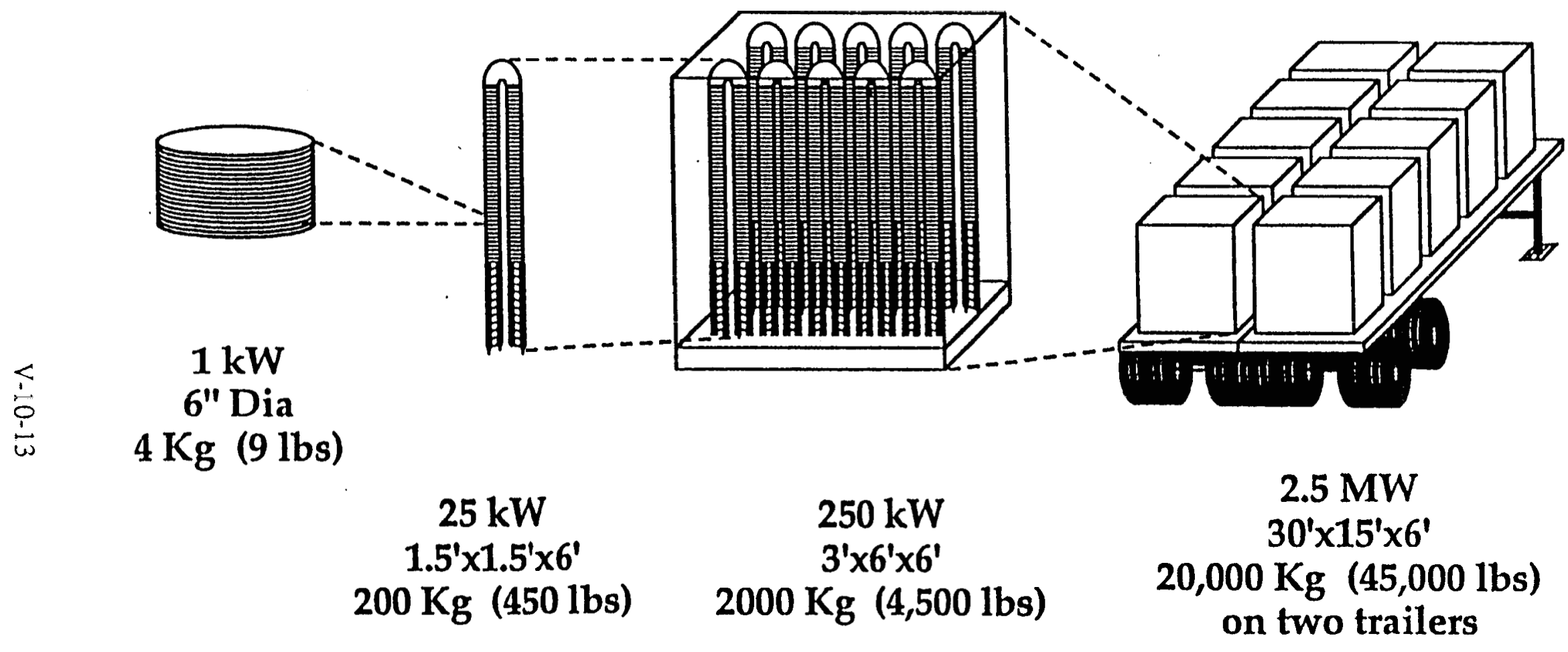

Figure V-10.3. Progression of Zirconverter Integration 


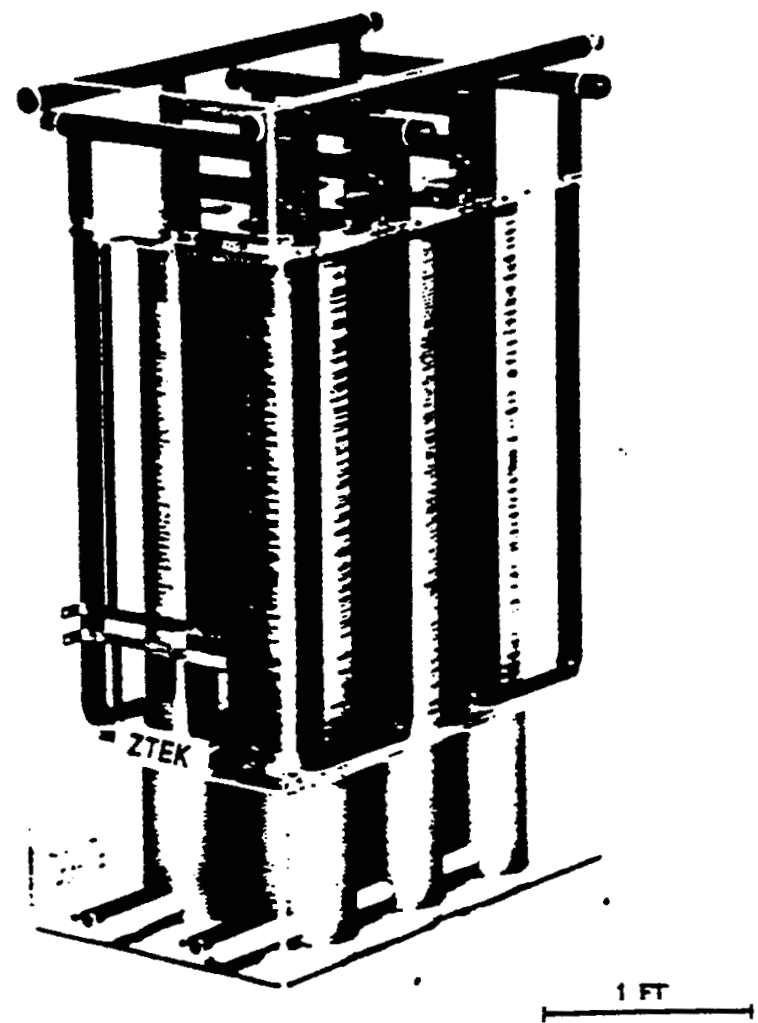

Figure V-10.4. Utility Module Demonstration Unit 


\section{ROLES OF DOE, EPRI, AND GRI IN FC-SYSTEM COMMERCIALIZATION}

FC-system commercialization has been viewed as a desirable national goal because of many perceived advantages over alternative electricity-generating systems. A more extended summary of these than is given in the preceding chapters is listed in Table VI-1.

Table VI-1.An extended list of desirable features and of features that require improvements for FC-systems. This table contains repetitive information that is included here for readers whose primary concern is with the roles of funding agencies and their likely motivation for supporting FC commercialization.

FCs are:

1. clean and non-polluting;

2. highly efficient and therefore produce less $\mathrm{CO}_{2}$ per unit of electricity generated than other fossil-fuel-based power-generation systems;

3. easily adapted to provide flexibility since they may be designed to utilize any primary fossil-fuel resource;

4. compatible with renewable energy because of the preferred use of $\mathrm{H}_{2}$;

5. especially well suited for optimal distribution of generated power with short transmission lines, thereby reducing costs and possible health issues involving electric power transmission;

6. high-technology devices that may be expected to contribute materially to exports and a favorable trade balance;

7. low consumers of water and therefore contribute to the conservation of valuable water resources;

8. well suited to small power-generation assemblies, which augments the reliability of operation of large complexes of systems;

9. relatively easy to maintain with low $O \& M$ costs according to the experience gained with PAFC systems;

10. suitable for both stationary and transportation applications; 
11. characterized by highly efficient operation that is almost independent of system size;

12. the high-temperature FCs are especially well suited for cogeneration applications;

13. low capital-cost market entries because they are usable in small units;

14. well suited to absorption cooling in high-temperature FC-system applications;

15. especially well suited for flexible planning because of their small modular sizes;

16. such low emitters that blanket federal permitting for FC installations has been accomplished for PAFCs, a feature that should easily be extended to other FC systems;

17. reliable producers of DC outputs that allow dependable power conditioning with high-quality electricity production at relatively low costs;

18. highly desirable examples of very clean technologies that will appeal to regulators at all levels of government after appropriate educational programs have been implemented;

19. properly scaled to reduce regulatory complexity at the local level;

20. very low noise sources during operation;

21. appropriate designs for easy market entry by independent power producers (who may not receive transmission and distribution or emission credits), thereby serving to facilitate deregulation of the electric power industry;

22. structured to provide low visual impacts and characterized by the absence of emission plumes;

23. safe to operate and it is practically impossible to contemplate an accident that extends beyond the boundaries of the FC-system installation;

24. not likely to be discarded after use because of the high value of recycled components.

The following features of FC systems require improvements:

1. currently unacceptably high costs must be reduced;

2. fuel selectivity must be improved;

3. although FC-stack costs are only about one third of system costs, it is desirable to increase FC power densities to reduce system sizes, which are now much greater than those of gas-turbine or diesel generators; 
4. materials costs are high and lower cost materials are desired;

5. FC-system complexity in current designs should be reduced to achieve cost reductions.

Since the market size is ultimately a function of system cost, FC-system commercialization is crucially dependent on entry-level and mature installation-cost estimates. FC-system commercialization will benefit from each of the following:

1. educational programs to familiarize potential buyers and utility engineers with the advantages and unique features of FC systems;

2. quantification of cost estimates showing the environmental, distribution and other advantages of FC systems;

3. education to familiarize local regulators and advocates with the environmentally desirable features of FC systems;

4. greatly improved information exchange between FC-system developers concerning R\&D results derived from government-supported studies;

5. concerted efforts to remove unnecessary regulatory inhibitors at the local level that refer to pre-FC-system generic power-generation issues;

6. multi-year advanced funding for product-improvement $R \& D$;

7. creation of a document center to serve the U.S. FC community that includes provisions for rapid translation and distribution of pertinent non-English articles selected from world-wide sources;

8. vigorous participation by multi-lingual U.S. nationals in all types of international conferences and discussions.

\section{VI-1. The Historical Role and Current Programs of DOE}

DOE and predecessor agencies have provided financial support for the development of FC systems since the 1970s. Initially, PAFC systems were the primary 
focus for DOE funding and this support contributed greatly to the present commercialization status of PAFC systems operating on NG.

During the last five years, MCFCs and SOFCs have received most of the DOE funding for FC systems. Among the stated reasons by DOE officials for this change of DOE funding are the following: PAFC systems have made commercial market entries and, furthermore, MCFC and SOFC systems promise higher efficiencies and lower capital costs and are well suited for cogeneration applications and ultimate integration with coal-gasification systems.

The DOE visions for FCs are competitive performance and cost, NG systems commercially available by 2000 , coal-derived systems demonstrated by 2010 , and U.S. companies providing major entries into world markets.

The DOE program strategy is to provide support until commercial production is initiated, focus on NG and coal-derived fuels because of their large resource bases, emphasize funding for research aimed at resolving major technical issues, recognize the market potential for on-site systems, and work cooperatively with EPRI and GRI on program development and funding.

There are recognized high-value applications for FC systems, including areas with environmental constraints, uses requiring highly-conditioned power, installations at substations to minimize transmission and distribution costs, cogeneration facilities in industrial parks and hospitals, selected locations where (low-Btu) gas (e.g., methane released at landfills) is available free of charge or at very low cost, and repowering of gas- or oil-fueled electric utility power plants.

Traditional and distributed electricity-generation systems are contrasted in Fig. VI-1.1.

\footnotetext{
* In the past, DOE has not been actively involved in commercialization efforts after initial market entry of a new technology.
} 
DOE funding for FC-system development is summarized in Fig. VI-1.2 for the period 1988-93. Reference to Fig. VI-1.2 shows a nearly time-independent funding level of about $\$ 1.5 \times 10^{6}$ for the technology base, declining funding for the PAFC with termination in 1993, steadily rising suppor: for MCFC and SOFC developments, and total funding that reached just over $\$ 50 \times 10^{6}$ in 1992 . The 1993 and 1994 DOE FC funding levels are summarized in Table VI-1.1. A decline from FY 1993 to 1994 in current dollars is noteworthy and shows actually reduced expenditures by about $3 \%$ when allowance is made for inflation. DOE is a major contributor to the construction of the 2MW ERC MCFC system at Santa Clara, CA, and the 250-kW M-C Power MCFC demonstration unit at San Diego, C.A.

Table VI-1.1. DOE Fossil Energy FC program funding (in millions of dollars) for 1993 and 1994.

\begin{tabular}{|l|r|r|}
\hline Program Activity & $\begin{array}{c}\text { FX 1993 } \\
\text { Funding } \\
\text { (Enacted) }\end{array}$ & $\begin{array}{c}\text { FY 1994 Funding } \\
\text { (Administration } \\
\text { Request) }\end{array}$ \\
\hline SOFC & 18.701 & 18.033 \\
MCFC & 30.945 & 29.798 \\
Advanced Research & 1.482 & 1.447 \\
\hline Total & 51.128 & 49.278 \\
\hline
\end{tabular}

In late 1993, DOE implemented a 60-month, 2-5 million procurement action for the development of one or two planar, low-cost SOFCs for use in multi-kW stacks. A 5year \$70-75 million allocation was made to two developers for a multi-fuel, packaged, simple, low-cost, modular, market-responsive MCFC plant leading to $500-\mathrm{kW}$ to $2-\mathrm{MW}$ 


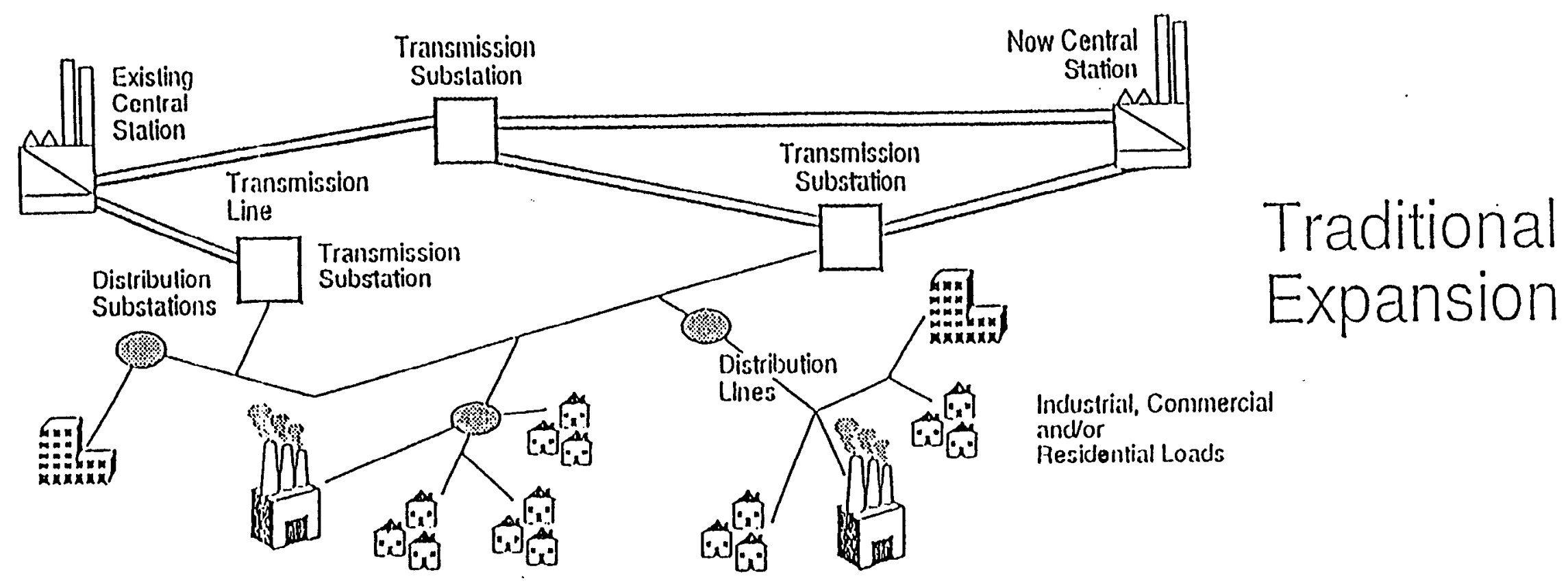

占

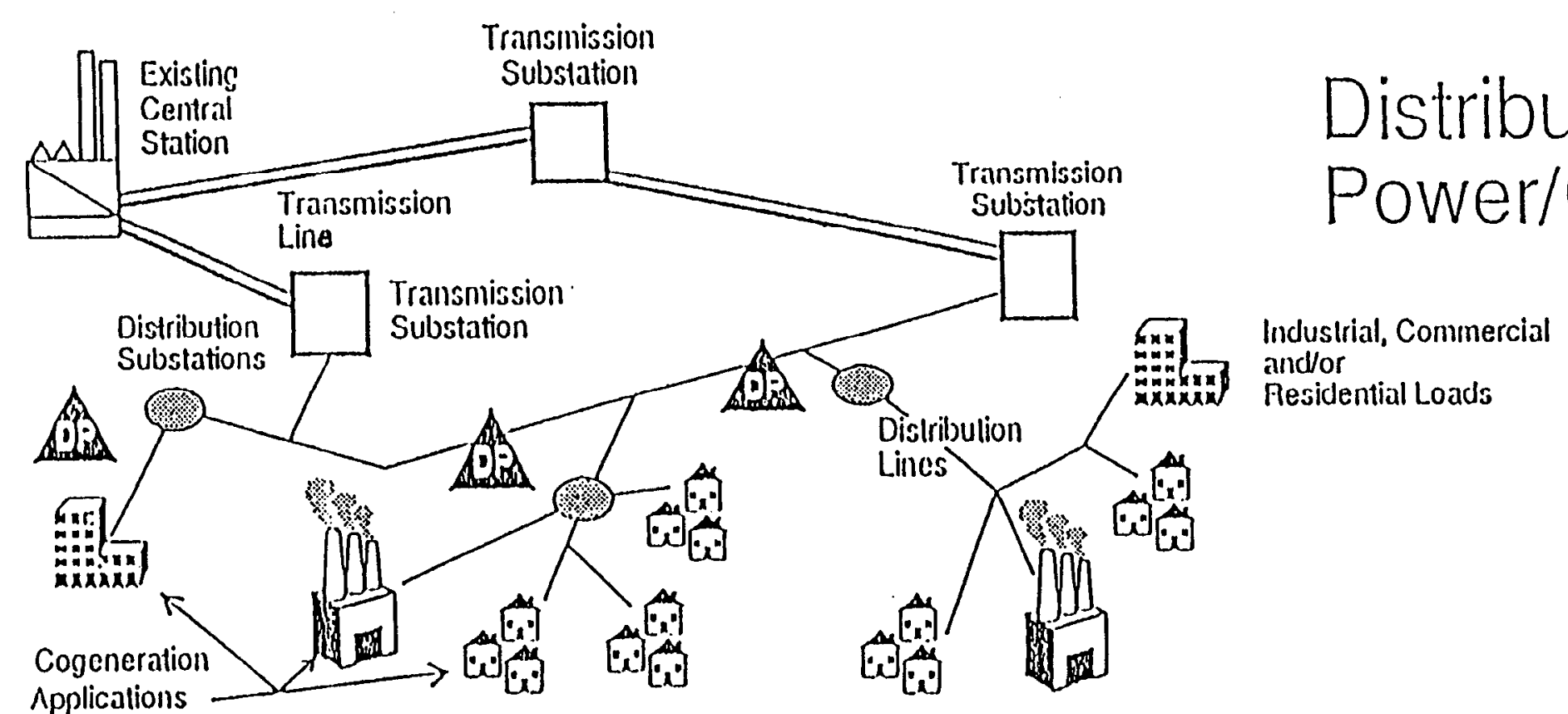

Fig. VI-1.1. Schematics showing tradilional expansion and new power/cogeneration opportunities provided wilh FC systems. 


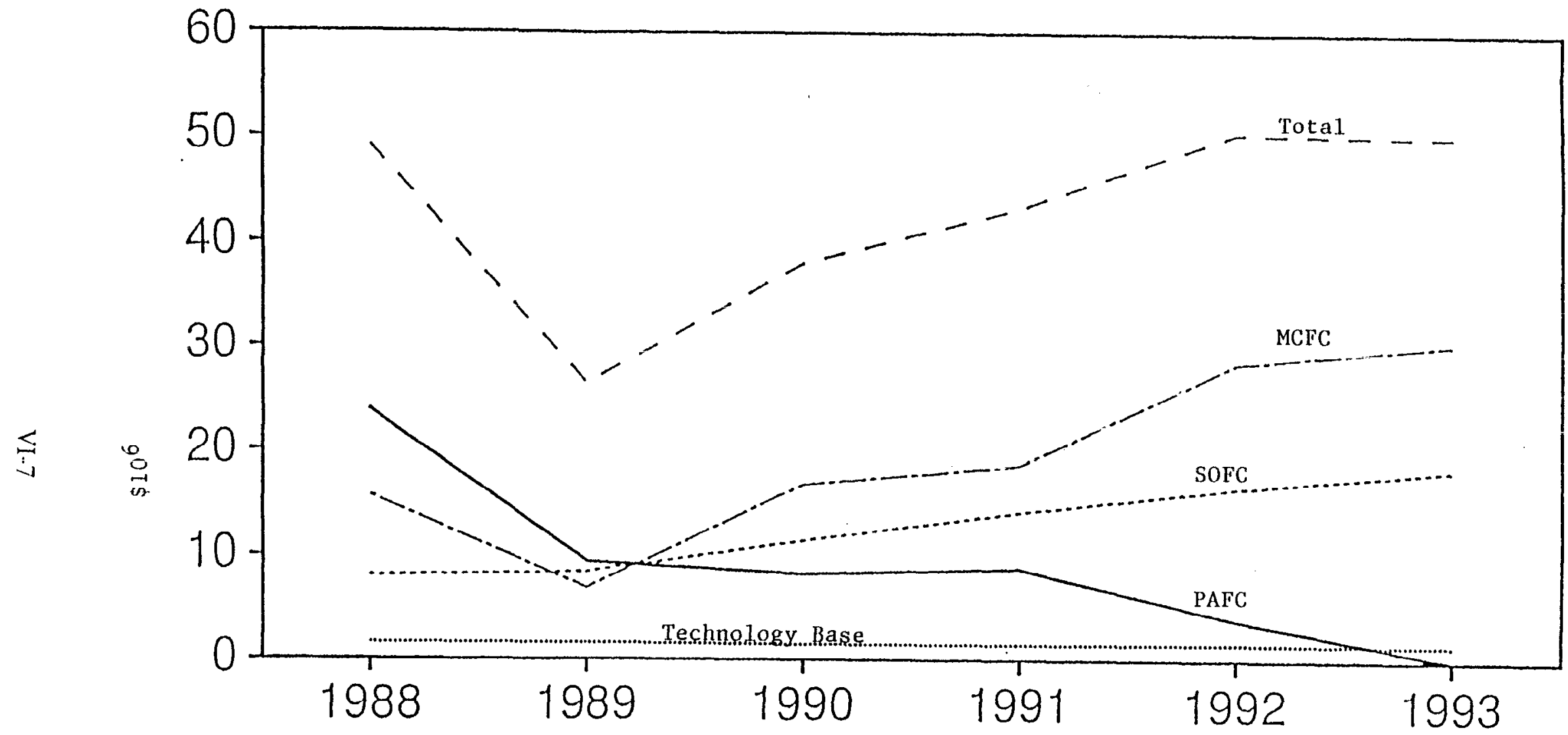

Fig. VI-1.2 DOE funding (in current dollars) for FC-System development for the period 1988 to 1993. 
power plants. DOE continues funding of a major program on the Westinghouse tubular SOFC system dealing with technology improvements involving longer tubes and higher power densities to reduce costs for 25 - and $100-\mathrm{kW}$ modules. The DOE program includes assessment of integrated-gasification FC technology, hot-gas clean-up technology and the effects of contaminants on FC performance.

From the DOE perspective, the following are paramount issues in successful FC commercialization: (i) continuity of funding by DOE; (ii) private-sector funding of manufacturing, system definition, and applications; (iii) establishment of joint ventures and teaming for demonstrations and commercialization; (iv) market acceptance based on low costs, performance, reliability, and customer benefits; (v) competitive suppliers of FC system components to ensure product improvements, service and cost reductions.

\section{VI-2. The Historical Role and Current Programs of EPRI}

The electricity suppliers of the future are expected to be (i) large, vertically integrated, energy-service companies of the type represented by many present-day electric utilities; (ii) fragmented generation, transmission or distribution companies; (iii) independent power producers (IPPs) participating in any and all of the utility-service

functions. A summary of currently anticipated U.S. electric utility capacity needs is given in Table VI-2.1, which shows demand growth for the 1991-2000 time frame of $105,600 \mathrm{MW}$, followed by required additions for 2000 to 2010 of $112,000 \mathrm{MW}$. Further growth from a total of $685 \mathrm{GW}$ to $1,295 \mathrm{GW}$ by 2030 is expected. FC systems will represent integral components for the projected generation-capacity growth. 
Table VI-1.2 Estimated U.S. electric utility capacity needs for the period 1991-2010. Sources: North American Electric Reliability Council 1991 baseline forcasts.

\begin{tabular}{|l|r|}
\hline \multicolumn{1}{|c|}{ Quantity } & \multicolumn{1}{c|}{ MW } \\
\hline Total required additions for 1991-2000 & 89,300 \\
Utility additions & 71,600 \\
Non-utility additions (IPPs, Co-generators) & 17,700 \\
Utility additions: & \\
under construction & 15,900 \\
not yet identified & 55,700 \\
\hline Total U.S. demand growth (1991 - 2000) & 105,600 \\
\hline 2000 - 2010 required additions & 112,000 \\
\hline
\end{tabular}

The current EPRI role in FC commercialization has been defined to include the following functions: For PAFCs, (i) monitor world-wide FC power-plant demonstrations and applications with emphasis on grid-connection issues and (ii) provide pertinent information to utilities on the implications of PAFC-system purchases. For MCFCs, (i) support the technology for NG-fired distributed applications, (ii) support scale-up of MCFCs to sizes needed for integration with coal gasifiers, (iii) evaluate the suitability of coal-derived, land-fill, and biomass-derived gases in FC-system utilization, while (iv) utilizing cell and stack components derived from larger DOE-funded efforts. For SOFCs, support R\&D to provide the foundations for improved SOFC technologies.

The utility market is seen to depend strongly on FC-system costs. At $\$ 2500 / \mathrm{kW}$, the market will be very small with generation use limited to selected distributed power applications. At $\$ 1500 / \mathrm{kW}$, there is a significant market for widespread distributed power generation. At $\$ 1000 / \mathrm{kW}$, the market is expected to be very large and to include both central-station and distributed generation.

Successful commercialization in the utility market requires each of the following: (i) multiple demonstrations, (ii) high reliability and good performance, (iii) predictable 
and acceptable O\&M charges, (iv) substantial participation by manufacturers, users, and regulatory agencies, (v) education and information dissemination to utility executives and engineers, regulators and the public, and (vi) ultimately economically competitive systems. To facilitate market entry, high-value market segments need to be identified to allow the payment of premium prices for favorable FC attributes such as ultra-low emissions and close proximity to users, where proper credits will be allocated for emission reductions and distributed generation advantages (i.e. low emissions of $\mathrm{NO}_{\mathrm{x}}$, $\mathrm{SO}_{\mathrm{x}}, \mathrm{CO}, \mathrm{HCs}$, minimization of wastes such as contaminated water, low ash and sludge production, reduced concern with electromagnetic effects, minimization of greenhousegas production, energy conservation through augmented conversion efficiency, and moderate land and water use).

From the utility perspective, the opportunity for distributed generation is of special importance. The use of distributed generation offers potentially lower cost of service at the customer's meter because of opportunities to reduce transmission and distribution costs, improved management of client needs, lower costs through potential competition at the delivery meter, as well as improved power reliability and quality at reduced environmental loads.

Schematic summaries of the advantages of distributed generation are given in Figs. VI-2.1 to VI-2.4.

\section{VI-3. The Historical Role and Current Programs of GRI*}

The Gas Research Institute (GRI) is the central R\&D organization serving the natural gas industry and its customers. GRI has historically and continues to make significant investments to advance the state-of-the-art of power-conversion technology,

\footnotetext{
* This material is based on a lecture given by M.P. Whelan of GRI (August 4, 1993).
} 
with the overall objective of facilitating commercial use. FCs have long been a significant part of GRI's portfolio.

The North American Electric Reliability Council's 10-year forecasts (1992 and 1993) show continued need for large capacity additions over the next decade. Most of the future power plants are expected to come from outside the traditional utility framework and it is likely that a large share of unidentified utility additions will be non-utility projects. A very small share of a large $(\approx 80 \mathrm{GW})$ market is a large business opportunity and short lead-time plants such as FC systems may be favored; 97 of 67,100 MW of utility additions in the 10-year forecast are likely to be FC systems.

In the view of GRI, the likely FC-market niche is the customer-generation and dispersed-utility-generation market, where customer generation is defined to encompass both cogeneration and prime power. This market is complex, not nearly as well characterized as the utility sector, and the average size of a system is relatively small. The promises of dispersed FC-generation benefits to utilities and their customers need to be verified through focused demonstrations to show that investments are recoverable on acceptable time scales.

Competing technologies to FC systems are not at all static. The efficiency, emissions and reliability performance of reciprocating-engine and gas-turbine technologies are continually improving. Because these products start out with a huge cost advantage, plans must be crafted around very modest FC-system market-entry manufacturing volumes.

The availability of NG at reasonable cost appears to be assured at least through the year 2010 (see Chapter VIII for details). 


\section{Definition:}

Any modular technology that can be distributed throughout a utility's service area to maximize benefits of matching the characteristics of the technology with the electricity demand, environmental and $\theta$ conomic attributes of its site.

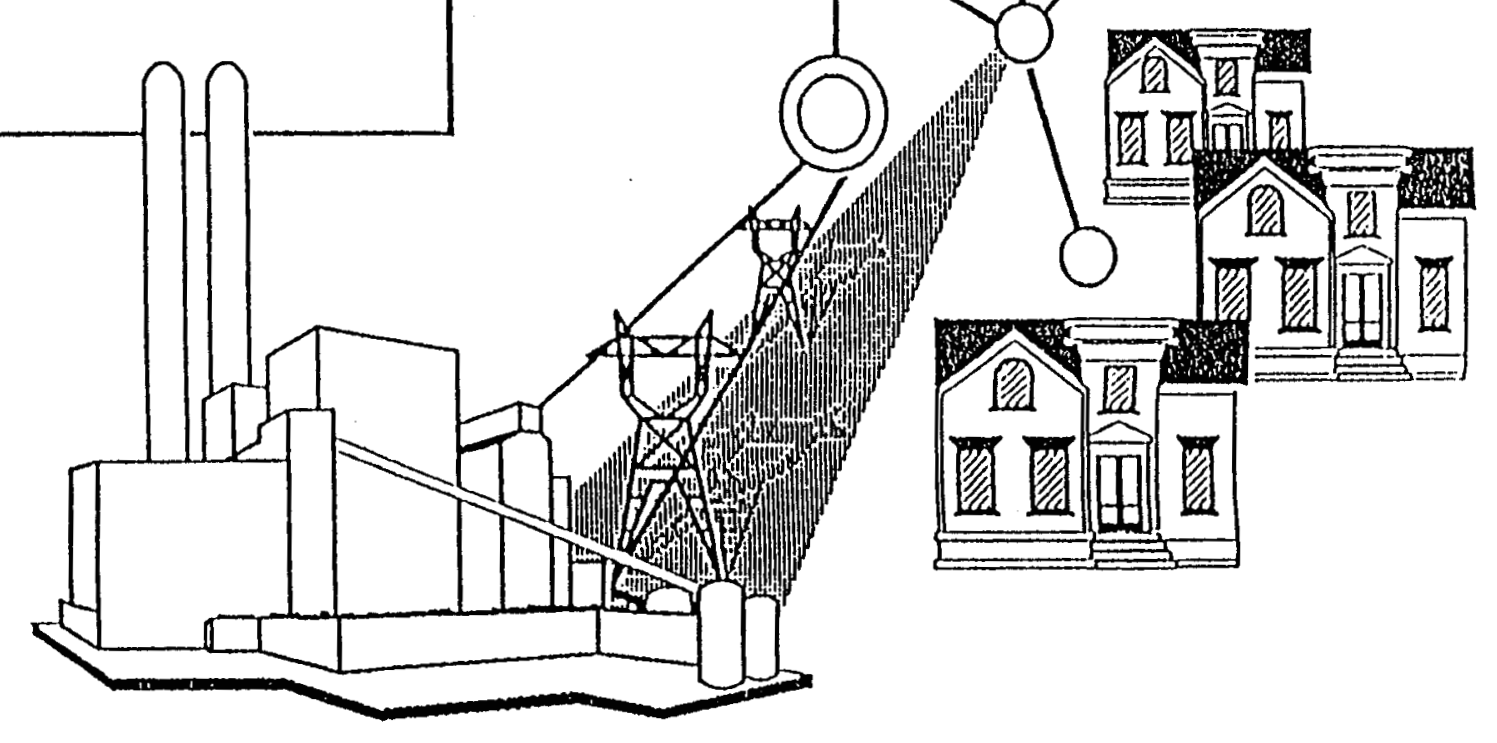

Fig VI-2.1. A schematic description of distributed generation. 


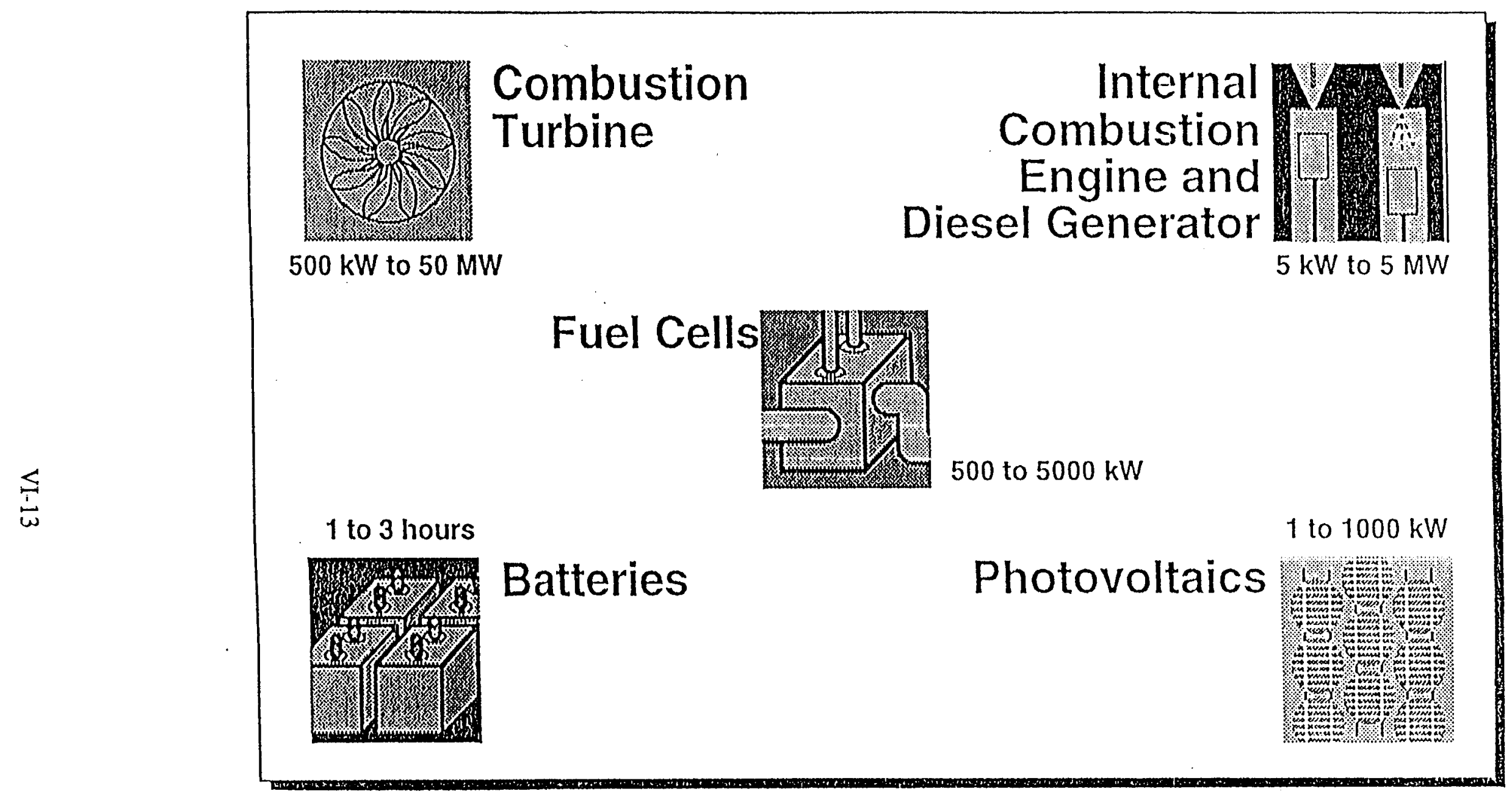

Fig. VI-2.2. A schematic perspective on the potential roles of FC systems and other distributed power sources. 


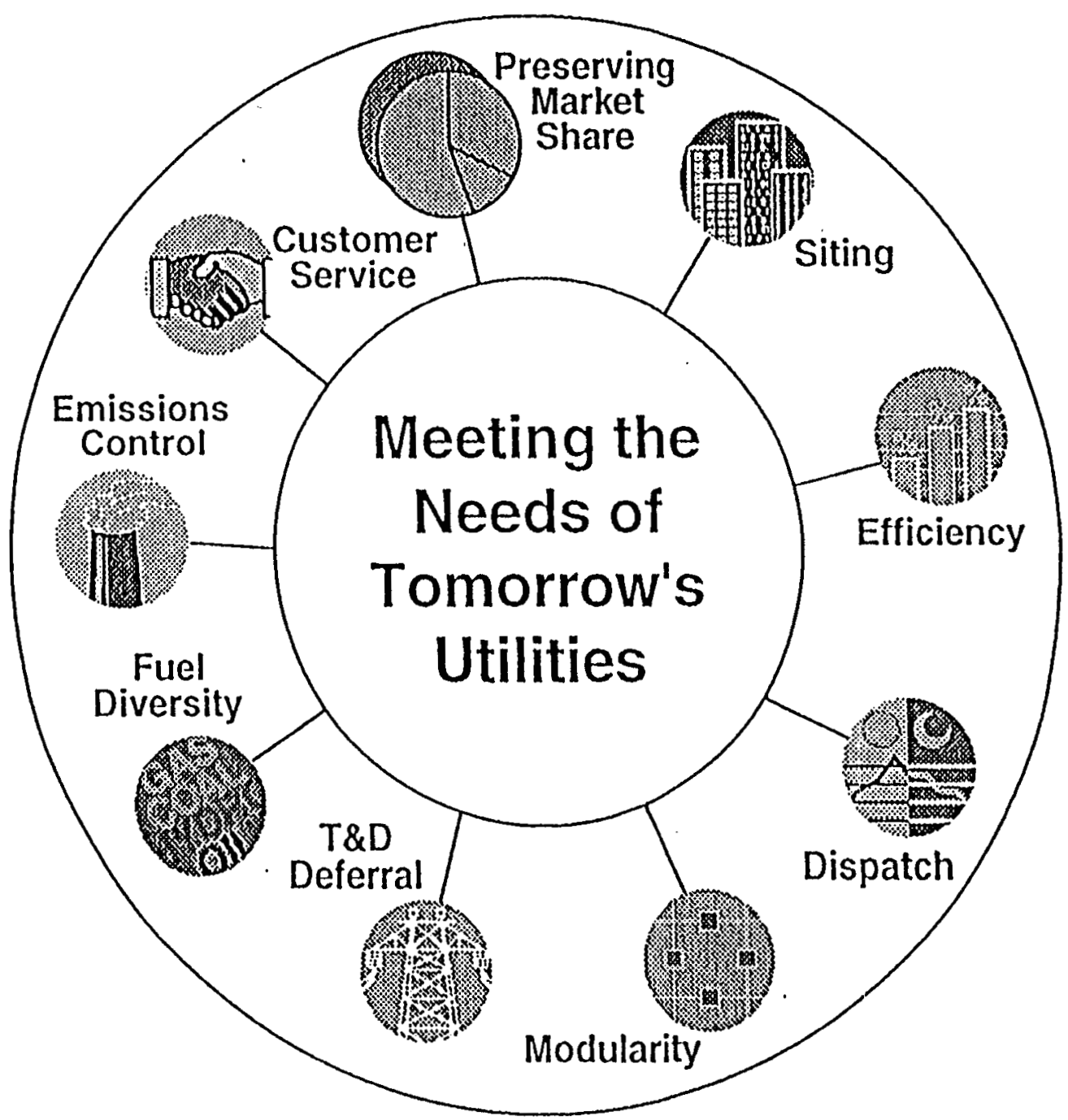

Fig. VI-2.3. A summary of benefits derived from FC use in distributed power generation. 


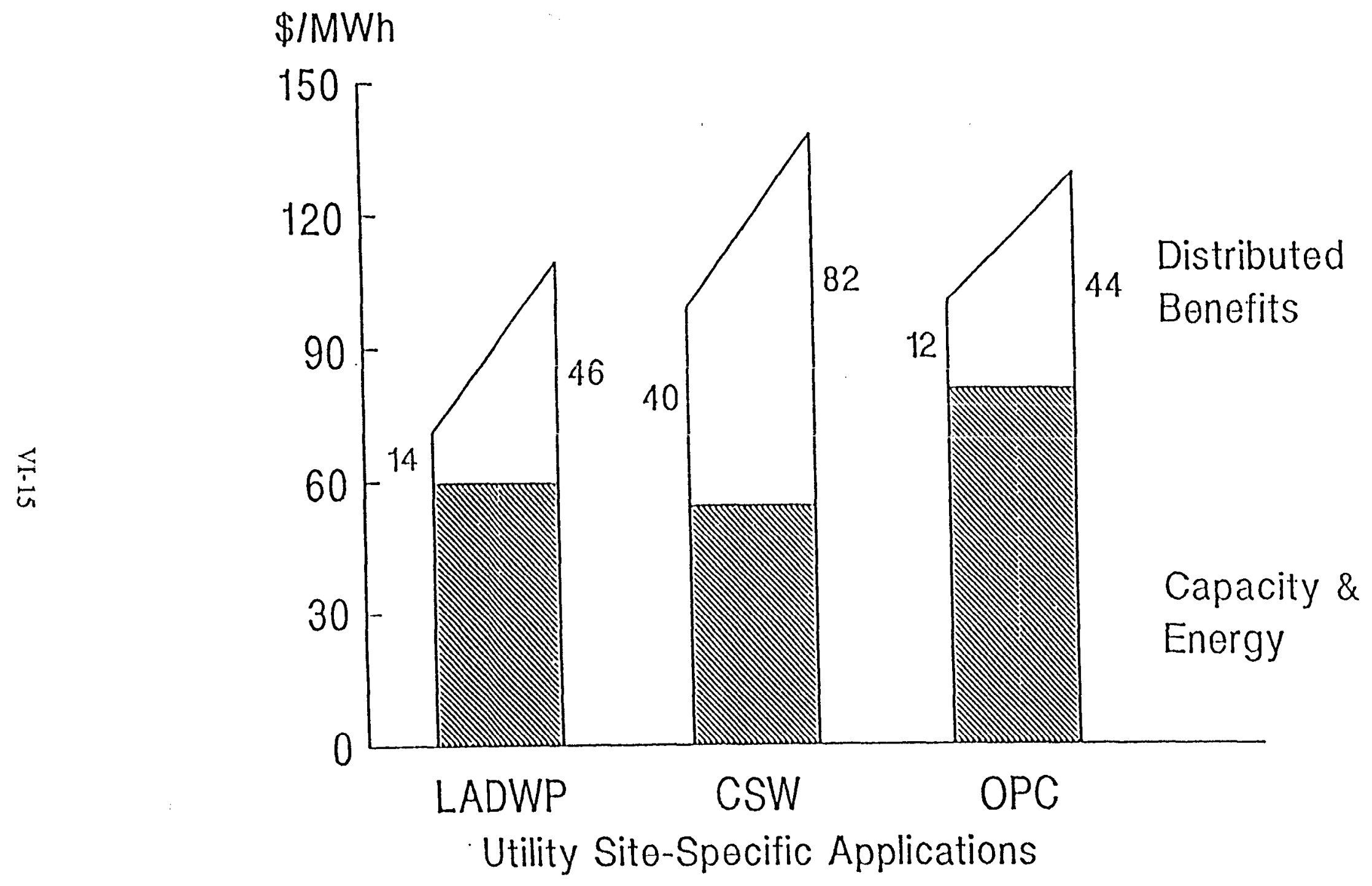

Fig. VI-2.4. Distributed generation benefits for a 2-MW MCFC (in levelized $1991 \$$ ). The trapezoidal tops of the block diagrams indicate ranges of estimated distributed benefits. 



\section{IMPACTS OF PUBLIC POLICY AND REGULATIONS ON FC-SYSTEM COMMERCIALIZATION}

There is a well recognized set of public measures at the federal, state and local

levels that will accelerate the implementation of FC-system commercialization. Among these are the following: (i) direct monetary support to manufacturing companies, electric or gas utilities, and electricity users for the purpose of reducing entry costs in demonstration and field testing of new FC systems; (ii) tax relief to manufacturers that amount to taxpayer support of RD\&D and marketing of FC systems; (iii) cooperation of state and regional regulatory agencies with FC-system builders to eliminate unnecessary costs (e.g., construction of walls to serve as sound barriers for non-existent system noise, excessively stringent and unnecessary regulations concerning waste-water quality, safety measures that are inconsistent with technically defensible worst-case failure scenarios, etc.). At the same time, FC-system commercialization efforts must remain sensitive and responsive to changes in the business climate and to possible developments of improving competitive technologies such as small, low-cost turbines with $\mathrm{NO}_{\mathrm{x}}$-emission levels below $10 \mathrm{ppm}$.

\section{VII-1. Implications of Utility Deregulation on FC-System Commercialization}

The commercial entry of FC technologies into the market place will be negatively impacted by deregulation of the utility industries. Major structural changes occurred first in the gas and now in the electric utilities. These industries have in the past pioneered new technologies. The associated risks have been moderated by their monopoly status and willingness of state-utility commissioners to allow rate-based costs to be passed on to customers. The new regulatory changes favor enhanced competition and lowest-cost providers. This change, coupled with after-the-fact prudency reviews, has inevitable led to a policy of avoidance of real or perceived risks. Electric utilities have begun to place 
generation assets into unregulated subsidiaries. As the result, it has become less likely that either utilities or their competitors will purchase high-cost market-entry units without cost sharing from other entities. As the costs of transmission and distribution (T\&D) increase, better management and utilization of assets must be emphasized. The result is likely to be preference of distribution from small (less than about $10 \mathrm{MW}$ ) generation rather than from central power (hundreds of MW) stations. This change expands the market for high-value applications that can absorb increased costs of new units. Valuing reliability and power quality, deferring $T \& D$ investments, considering $T \& D$ losses, and properly crediting emissions and efficiency benefits may well lead to acceptance of market-entry hardware with costs above the market clearing price, even in a severely competitive environment because the in-place assets may be used to advantage by the utility.

In the new market environment, the future role of the government becomes critical and new options may be needed for the FC user and manufacturing communities.

FC-system entries will result because some buyers want to become familiar with the new technology and learn how to integrate it into operational networks. Purchases will be made because of the environmental advantages of using FC systems. Finally, a market may develop because the use of conventional combustion systems has been interdicted as the result of one of the many real or perceived problems that accompany their use. However, all of these sales promotions combined will not lead to commercial success, unless competitive costs for delivery of electricity at competitive reliability and quality are achieved.

An innovative independent power producer might select an especially vulnerable feature of an established utility system and find it profitable to create a highly specialized market for which FC systems are especially well adapted. Examples may be supplying distributed power to end users in a large utility network or identifying specialty 
installations such as hospitals, industrial users, schools, and other public facilities for installation of small FC systems. By selecting the most vulnerable features of utilitydelivery systems, independent power producers using FC systems may be able to provide lower cost services than can be obtained from the tail end of a conventional utilitydistribution network.

It is unclear at this time what types of supplier-user-subsidy arrangements can be put together by new entries into the electricity-supply market for the purpose of FCsystem utilization. Furthermore, prospective deregulations have such a long time horizon (i.e. 6 to 8 years in the future) in most instances that this planned delay may allow continued opportunities for regulated-utility support over a sufficiently long time period and for a sufficiently large number of installations to reduce FC-system costs to competitive levels by the time full deregulation is implemented.

In view of uncertainties surrounding present plans for utility deregulation, it is appropriate to conclude with the observation that careful monitoring of developments in deregulation at the state and regional levels will be required in the pursuit of an orderly program of FC commercialization in the U.S. with support from federal or state agencies and the private sector.

\section{VII-2. Environmental Policy as a Driver for FC-System Commercialization}

It is axiomatic that all power-conversion systems must operate in compliance with regulatory emissions requirements. Conventional power-conversion devices readily meet existing emission standards and are often far cleaner with respect to emissions of criteria pollutants than is mandated. Conceivable future problem areas relate to large organic molecules, which have not yet been adequately classified with respect to allowable emission levels considering possible short- and long-term health effects. In the future, new information may become available on organic compounds for which, as for dioxins 
and furans now, proposed emission requirements may be specified at the limits of detection with sophisticated measurement techniques.

In the past, there has been a growing propensity to impose best available technology standards. With directives of this type, it may not be too far-fetched to consider the possibility that at some time in the future, the very low pollutant emissions of well-operating FC systems may become mandated norms, especially if the associated economic penalties are not excessively large. An example of this type of extreme market directive is provided by the legislated requirement for a specified number of zeroemission vehicles that must be offered for sale in California in the not too distant future. In summary, the extreme environmental cleanliness of FC systems is not conducive to creating an immediate market monopoly but does represent a potential long-term advantage that may be recognized in the future by defining FC systems as singular and the only acceptable power-conversion market entries and commercial systems.

The foregoing remarks should not be interpreted to mean that this Working Group supports environmental regulations beyond scientifically defensible limits in order to advance the commercialization of any economically non-competitive systems including FC power-conversion units.

\section{VII-3. Selective Tax Relief to Target Specialty Markets}

Tax relief for fuel-cell operators and direct cash subsidies to operators and manufacturers can greatly reduce costs and speed FC commercialization. Since specialized market sectors have different cost hurdles to commercialization, different subsidies and tax reductions should be targeted for each sector. In this manner, the minimum needed support for commercialization should reach each market sector. Any broad system of subsidies and tax relief would treat all market sectors equally, overassist 
some markets that are perhaps nearest to commercialization, waste government money, and unnecessarily increase the cost of commercialization. By granting selective subsidies and tax relief to FC operators and manufacturers, the government is intruding into the power-conversion market, favoring FC. sales, and interfering with the orderly activities of other power-conversion-equipment makers and users. This problem must be recognized as both a consequence and a goal of policy and poses a special challenge in arriving at proper implementation measures. 



\section{FUEL SELECTION AND AVAILABILITY}

Fuels for FC applications, after proper reforming, ultimately include any and all fossil-fuel resources, as well as hydrogen produced either by chemical processes, reforming or use of renewable energy sources. The potential resource base is adequate for fuel supplies required over a period of several hundred years from conventional resources including coal, for many additional centuries with fuels derived from syntheticfuel operations and almost indefinitely for $\mathrm{H}_{2}$ obtained through water splitting by the use of renewable or fusion energy. Over the near term, the primary fuel will be natural gas (NG), with integrated coal-gasification systems not becoming a technical reality until more than at least a decade later. Additional supplies include gases derived from landfills and crude ethanol (as in Anoka, Minnesota) and gases from biomass (as in Maui, Hawaii). Coal gasification is being actively pursued, for example, at Plaquemine, Louisiana, while advanced coal-liquefaction processes are under development at Wilsonville, Alabama, and elsewhere.

For the purposes of the present study, the primary interest is in costs and availability of NG during the next few decades.

\section{VIII-1. Costs and Availability of NG}

The use of NG in FC systems will amount to a very small fraction of its total use or of available supplies during the foreseeable future. The question of fuel availability for FC systems may therefore be answered by simply citing authoritative references on the availability and cost of NG. Information made available during the last few years indicated adequate levels of NG supplies at roughly current, inflation-adjusted prices at least through the year 2020 . 
A recently published report from GRI ${ }^{1}$ contains useful projections for future gas supplies. According to this study, ${ }^{1}$ the estimated consumption growth in the U.S. from 20.8 quads $^{*}(q)$ in 1993 to $28 \mathrm{q}$ in 2010 requires new technology without which supplies and prices cannot be assured and gas shortages or price increases may be anticipated to occur as early as the late 1990s. The anticipated increase in gas use is, in part, the result of low current prices and is expected to accompany a total primary energy-consumption increase from $73.2 \mathrm{q}$ in 1993 to $106.8 \mathrm{q}$ in 2010 . The current long-term outlook for low prices is based on the assumption that oil-price hikes will not be sustainable because of a multiplicity of new supplies that are being brought on-stream in various parts of the world; the per barrel price of oil is estimated as \$19 in 2000 and $\$ 21$ in 2010.

The industrial gas demand is expected to rise from $9.1 \mathrm{q}(3.4 \mathrm{q}$ for process-steam production) in 1993 to $12.3 \mathrm{q}$ (5 q for steam) in 2010 . The consumption by electric utilities is expected to rise from $2.8 \mathrm{q}$ in 1993 to $4 \mathrm{q}$ in 2010 while that of the independent power producers (IPPs) increases from $0.1 \mathrm{q}$ in 1993 to more than $0.8 \mathrm{q}$ in 2010 .

Availability of supplies at reasonable prices hinges on advances in supply-side technologies. Imports from Canada are expected to grow to $14 \%$ of total demand by 2000 from $11 \%$ in 1993 . Subsequently, additional domestic and imported (mostly in the form of LNG) supplies are expected to become availably at reasonably constant prices.

Although the history of price projections coupled to demand growth for fossil fuels has shown large errors and variations during the seventies and early eighties, more recent projections have been relatively stable. Furthermore, the current procedure of periodic updating of estimates should provide adequate lead time to allow remedial actions if significant supply shortages are indicated some years in the future.

1 "1995 Baseline Projections of U.S. Energy Supply and Demand," GRI, Chicago, IL (1994); this report is summarized in The Energy Dailey, Volume 22, Number 158 (August 18, 1994).

${ }^{*} 1$ quad $=10^{15} \mathrm{Btu}_{\mathrm{t}} \equiv 10^{12} \mathrm{SCF}_{\mathrm{NG}} \equiv 9.66 \times 10^{7} \mathrm{MWh}$ at $33 \%$ fuel-to-electricity conversion efficiency. 


\section{VIII-2. Use Rate of NG with Developing FC Capacity for Electricity Generation}

For a thermal energy content of $10^{3} \mathrm{Btu} / \mathrm{SCF}_{\mathrm{NG}}$ for natural gas (NG) and a $50 \%$ FC-conversion efficiency to electricity, the generation of $1 \mathrm{MWh}$ requires the consumption of $(1 \mathrm{MWh}) \times\left(2 \mathrm{MW}_{\mathrm{t}} \mathrm{h} / \mathrm{MWh}\right) \times\left(10^{6} \mathrm{~W}_{\mathrm{t}} / \mathrm{MW}_{\mathrm{t}}\right) \times\left(0.949 \times 10^{-3} \mathrm{Btu}_{\mathrm{f}} / 2.78 \times\right.$ $\left.10^{-4} \mathrm{~W}_{\mathrm{t}} \mathrm{h}\right) \times\left(1 \mathrm{SCF}_{\mathrm{NG}} / 10^{3} \mathrm{Btu}_{\mathrm{t}}\right)=6.83 \times 10^{3} \mathrm{SCF}_{\mathrm{NG}}$, i.e. the NG requirement for the equivalent of a $1 \mathrm{MW}$ plant operating for 1 year at unit load factor is $\left(6.83 \times 10^{3}\right.$ $\left.\mathrm{SCF}_{\mathrm{NG}} / \mathrm{MWh}\right) \times\left(8.76 \times 10^{3} \mathrm{MWh} / \mathrm{MWyr}\right)=5.983 \times 10^{7} \mathrm{SCF}_{\mathrm{NG}} / \mathrm{MWyr}$. Hence, the equivalent of $2000 \mathrm{MWyr}$ of electrical energy output per year is $1.2 \times 10^{11} \mathrm{SCF}_{\mathrm{NG}} / \mathrm{yr}$, whereas $20,000 \mathrm{MWyr}$ generation capacity will require $1.2 \times 10^{12} \mathrm{SCF}_{\mathrm{NG}} / \mathrm{yr}=1.2$ $\mathrm{TCF}_{\mathrm{NG}} / \mathrm{yr}$. Thus, a projected worldwide FC capacity of $2000 \mathrm{MWyr}$ in each the U.S., Japan, Western Europe, and the LDCs by the year 2000, followed by ten-fold growth to 20,000 MWyr capacity by 2010 , implies NG consumptions of 0.48 TCF $_{N G}$ and 4.8 TCF $_{N G}$, respectively. These are large growth rates. However, most of this increased use of NG for FC applications may be expected to replace less efficient technologies involving NG applications or coal burning. The net increase in needed NG supplies is therefore much smaller than that indicated by the estimates of NG use for FCs. As stated in Sec. VIII-1, current reserve-growth and cost estimates for NG suggest that the introduction of FC technology will not lead to price escalation or stress worldwide NG supplies at least through the year 2020. 



\section{NEAR-, INTERMEDIATE- AND LONG-TERM SUPPORTING R\&D TO REDUCE SYSTEM COSTS AND IMPROVE PERFORMANCE}

In the context of a product-improvement agenda and cost reductions for commercial systems, the following descriptions of the different types of FC systems should contain related discussions on the balance of plant with emphasis on reformer technology and power-system engineering. However, as has been repeatedly stated in this report, the FC-system development status is greatly different for the different types of fuel cells and only the PAFC system has reached commercial manufacturing levels with widespread market experience. As will be apparent from examination of the following sections, the presentation on the PAFC system in Sec. IX-1 is a model prescription for a product-improvement agenda aimed at cost reductions and reliability improvement for a commercial item. While protecting proprietary interests, the need for balanced product improvement is clearly stated and issues involving the FC stack are placed in proper perspective with respect to the BOP.

With input provided by Dr. B.S. Baker of Energy Research Corporation, balance of plant issues are also addressed for one of the MCFC systems.

Unfortunately, no comprehensive prescriptions can be offered for the other FC systems for two reasons, namely, the absence of large-scale market experience and the impediment of competitive pressures which has forced this Working Group to limit the discussions in the other sections of this chapter to issues involving $R \& D$ requirements on electrochemistry and FC-stack design.

\section{IX-1. Research to Make Better and Cheaper PAFC Systems*}

PAFC power-plant technology is the only FC alternative to have been introduced into the market on a commercial basis. No other FC technology has as yet been subjected

\footnotetext{
${ }^{*}$ This section was written by J. King and P. J. Farris of IFC.
} 
to meaningful numerous commercial applications. The advanced status of PAFC systems is the result of the following features: (i) PAFCs operate well with gaseous products which are readily and efficiently produced from NG. Because PA does not interact with carbon oxides and because the operating temperature of the PAFC provides electrode tolerance to small quantities of carbon monoxide, measures to remove carbon oxides from fuel gas or air are not required. (ii) The PAFC operates at temperatures that are consistent with the use of reject heat to raise steam for the fuel processor and at temperatures which satisfy space-conditioning (heating as well as absorption cooling), low-pressure steam and domestic hot-water requirements which constitute the thermal demands of residential, commercial and health-care buildings. (iii) The basic material of construction is graphite, which is a relatively low-cost, easily worked material. (iv) Operating temperatures in the 300 to $400 \mathrm{~F}$ range facilitate rapid development. The absence of an electrolyte phase change between shut-down and operating conditions avoids mechanical and operational constraints and problems. Cell-stack heat loss is not a significant factor detracting from part-load efficiency.

The specified features encouraged early PAFC-system development with application testing beginning in the late 1960s. Through a series of multiple power-plant application tests of both ambient-pressure and pressurized power plants ranging from 12.5 to $11,000 \mathrm{~kW}$, the requirements for a practical system have been thoroughly defined and power-plant designs which meet all performance and operating requirements in a unit with high reliability and durability have been established. The total application experience exceeds $900,000 \mathrm{~h}$ with over $300,000 \mathrm{~h}$ accumulated on the latest design, the $200-\mathrm{kW}$ PC ${ }^{\mathrm{TM}} 25$ power plant, which demonstrated required performance, reliability and durability characteristics. A significant part of the power-plant effort has been dedicated to fuel processing, thermal management, water management, power conversion, and control-system components and subsystems, which are integrated with the cell stack in a 
complete power-plant system to produce useful electric and thermal power from NG. Manufacturing approaches consistent with production of hardware approaching the price required for full market penetration have been developed and capital equipment with a delivery capacity of $40 \mathrm{MW} / \mathrm{yr}$ has been installed and operated on a continuous production basis. This effort has involved a team of commercial suppliers who have contributed design and development expertise and commercial hardware and processes to both the cell stack and other power-plant components.

The remaining technical challenge for PAFC marketing requires reducing the capital cost to levels permitting widespread commercial entry. This challenge applies to every element of the power plant and includes fuel processing, the cell-stack design, power conditioning and control, and ancillary components plus assembly. Once this challenge has been met, further technology developments can be used to improve efficiency and reduce size while maintaining the required initial cost level. Since government funding for PAFC development was terminated in the 1980s, the design and development required to meet commercial goals have been carried out with private funding and have had to compete for priority use of limited funds with other business opportunities for production facilities, product-support infrastructure development, organizational development, and market growth. Because of substantial private investment, details of the current technology position and the requirements and concepts for advancement are proprietary. The progress and requirements are described in general terms in the following section, which deals with historic progress in the development of PAFCs and indicates that considerable future improvement is likely.

\section{IX-1.1. Research and Development Needs}

\section{IX-1.1A. The Cell Stack}

The challenge of cell-technology development is implementation of a low-cost stack that is stable and has high performance over the power-plant operating period of at 
least 5 years. Cell-stack operations in a number of commercially delivered power plants now exceed $13,000 \mathrm{~h}$ with good performance stability. Analytical models of materials behavior supported by materials tests and tear-down results from cell stacks operating as long as $25,000 \mathrm{~h}$ (three years) support estimated overhaul periods of well over 5 years for the cell stack. Consequently, the major factor affecting the cell-stack overhaul period is performance stability at the higher current densities expected in the future. Improvements to cell-performance stability involve improving the stability of the materials of construction of the electrode (catalyst, graphite and fluorocarbons), as well as designing the electrode to tolerate changes which are likely to occur. Cell-stackperformance stability data indicate that recent changes to the electrode have increased performance stability while the operating current density has been increased by $25 \%$. Further improvements will require increased understanding of fundamental electrode performance and decay phenomena, followed by action based on this understanding to attack the factors involved with decay. Active, sustained research in this area should have the goal of achieving 10-yr overhaul periods for cell stacks operating at current densities 50 to $100 \%$ higher than the units currently in the field.

PAFC performance is limited by activation, resistance and diffusion losses. The historic performance-increase experience is associated with increasing temperature, improved cathode catalysts, reduced resistance losses, and improved mass transport in the electrodes. The resulting improvement in the power density of cell stacks delivered in a production situation is shown in Fig. IX-1.1 together with projections for near-term improvements. The primary loss in the PAFC is associated with activation loss which is a result of the reaction path and catalyst activity. Alternative catalysts and/or electrolyte systems have long been sought to reduce activation loss and catalysts used in IFC's power plants represent the state of the art of catalyst technology. Research on catalysts and cell concepts which change the cathode reaction path may prove to be valuable in increasing 


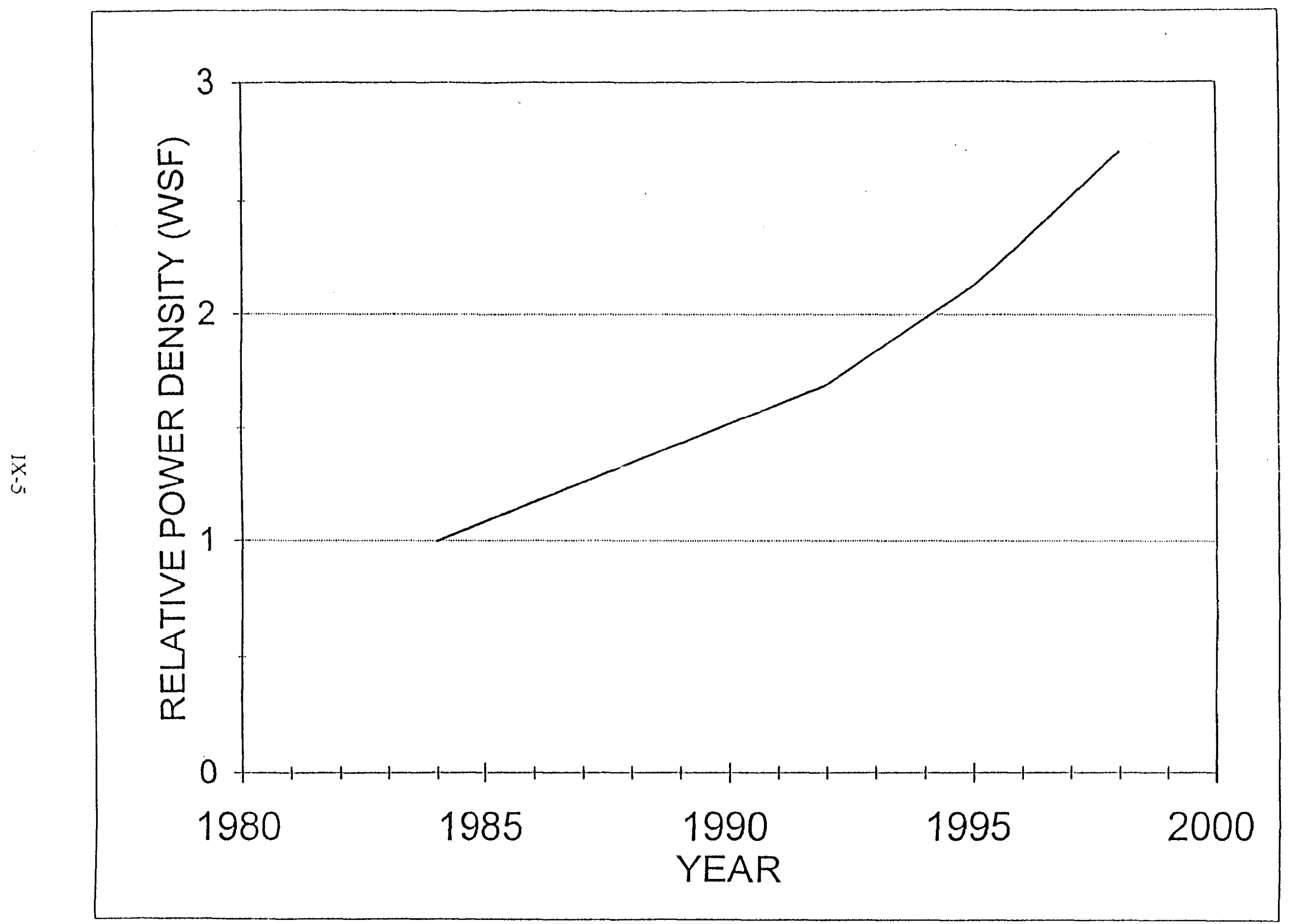

Fig. IX-1.1. Cell-stack power-density improvement projections for IFC PAFCs. 
the power density and/or efficiency of the PAFC. Additional losses are associated with resistance and diffusion. Reductions in diffusion losses through development of improved electrode structures is another fruitful area for research.

The overall cost of a cell stack is associated with the specific cost of the cell on a $\$ / \mathrm{ft}^{2}$ basis and the power output per unit cell area (W/ $\left.\mathrm{ft}^{2}\right)$. Figure $\mathrm{IX}-1.2$ shows recent experience in reducing cell cost per $\mathrm{ft}^{2}$, together with projections for the concepts that are now under development at IFC. These improvements have resulted from careful evaluation of factors associated with cell costs to develop designs and manufacturing processes which produce parts meeting the demanding requirements of the cell stack while achieving reasonable cost per $\mathrm{ft}^{2}$. Cost reduction has come from manufacturing process research to reduce scrap and waste through processing to net shape and through use of materials with more rugged properties, eliminating high-cost processes which involve either high-energy input or large rework efforts, and adaptation of single-step processes permitted by the use of alternative materials. This effort has been carried out with private funding at IFC and a number of suppliers and is proprietary. The general areas of effort have involved processing of graphite particles and fibers and resins to produce both dense and porous structures with properties meeting requirements for fuelcell use. Generally, these structures must have high corrosion potential and low corrosion rates in the PA environment, reasonable tensile and flexural strength to minimize processing scrap, high electrical and thermal conductivity, and pore sizes (generally in the tens of microns and below levels) consistent with cell function. Research on resins which provide good conductivity and durability at cell operating conditions and on the production of graphite parts with the noted properties will reduce the cost of PAFCs. Research should be conducted in cooperation with the cell-stack manufacturer to ensure that all factors associated with the overall requirements are considered. 


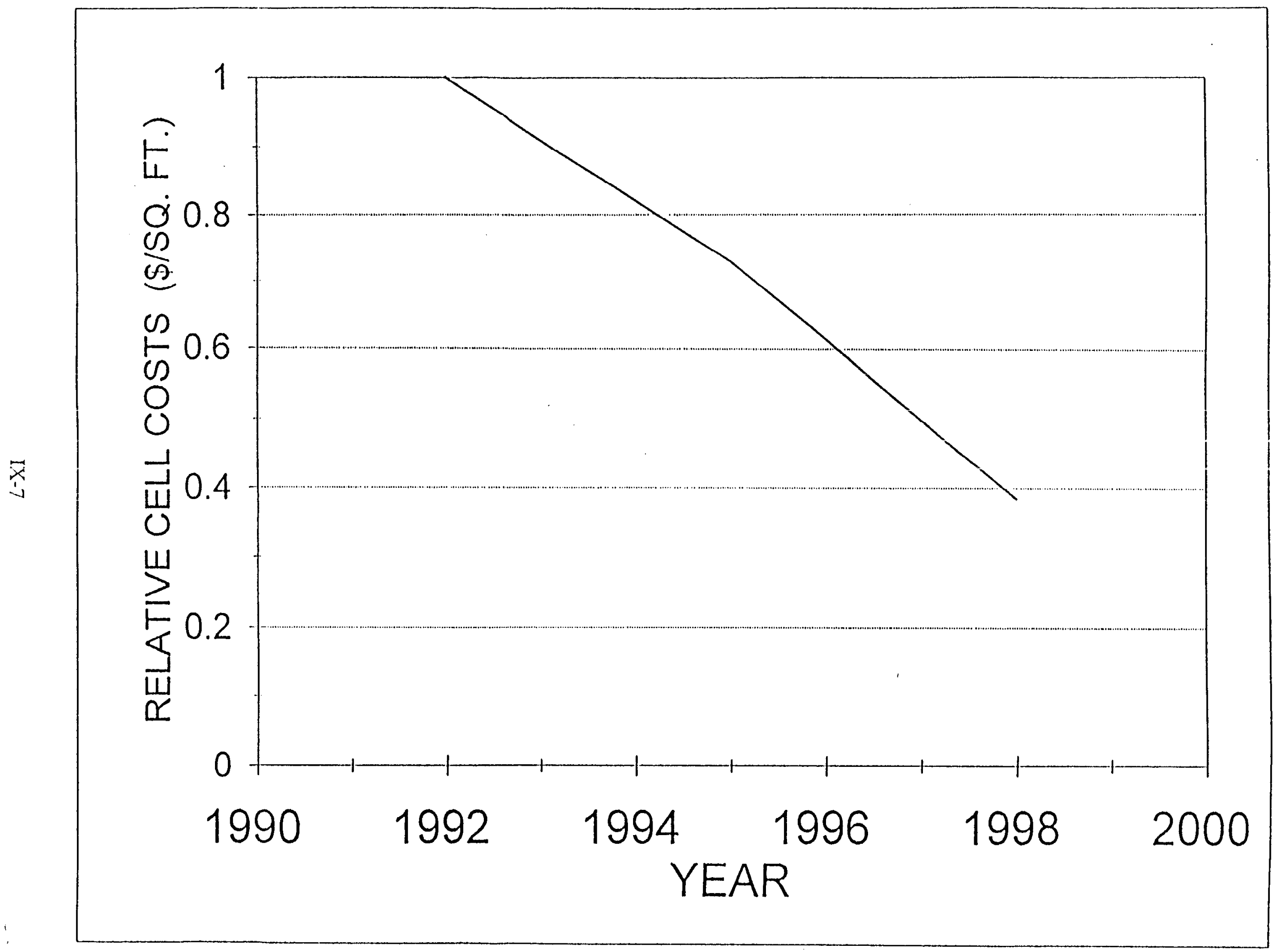

Fig. IX-1.2. Cell-stack improvement projections for IFC PAFCs. 


\section{IX-1.1B. The Fuel Processor}

Most PAFCs have been designed for operation with NG, which is widely available by pipeline distribution systems at low cost and complements the characteristics of FC power plants because it is clean and its supply is unobtrusive. The fuel processor to convert $\mathrm{NG}$ to the $\mathrm{H}_{2}$-rich fuel gas required for use in a PAFC involves steam reforming (methane plus steam react over a catalyst at an end-process temperature of 1300 to 1400 F to produce $\mathrm{H}_{2}$ and $\mathrm{CO}$ ) followed by shift conversion ( $\mathrm{CO}$ and steam react over a catalyst in the 400 to $500 \mathrm{~F}$ range to produce additional $\mathrm{H}_{2}$ and $\mathrm{CO}_{2}$ ). Since the reform catalyst is poisoned by sulfur, odorants in NG are removed in a self-contained process upstream of the reformer. This approach is well known in the chemical process industry, but it is normally applied at a large scale as part of an integrated, continuously manned chemical plant in which load-following capability, high efficiency and low manufactured cost for the capital equipment are not especially important to application success. The development effort for the FC has been associated not with fundamentals of catalyst or process behavior but rather in achieving mechanical designs which provide high efficiency, operating flexibility and low capital cost in the FC-application context. These activities have been carried out in conjunction with both catalyst and fabrication suppliers. The results of the development activity have been quite successful, as is indicated by the cost trend shown in Fig. IX-1.3. Continued development will be carried out using novel mechanical designs, fabrication techniques and catalyst approaches to reduce size and cost. There is widespread expertise on heat transfer, mechanical design, chemical reactions, and catalyst uses for FC power plants and applications.

Most of the stationary power use of FC systems will involve NG. Transportation applications are likely to involve methanol or hydrogen and remote applications could require propane or light liquid fuels. These fuels can be and have been applied with minor modifications to the processes used for NG. For portable and some remote 


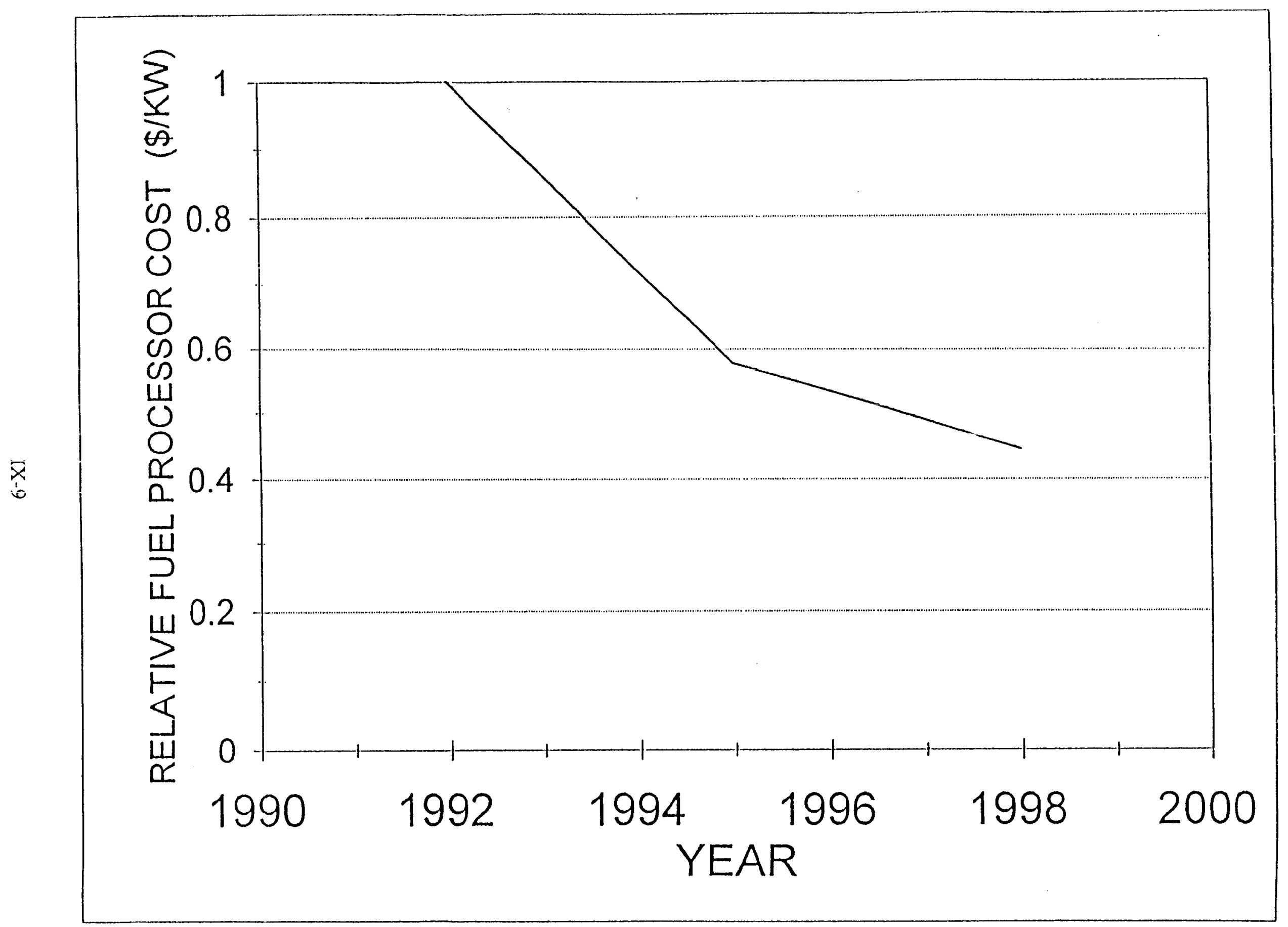

Fig. IX-1.3. Fuel-processor improvement projections for IFC PAFC systems. 
applications in both developed and developing countries, liquid fuels such as kerosene or diesel are desirable. These fuels require more aggressive treatments with higher processing temperatures as in auto-thermal or adiabatic reforming. While development has been and is being carried out on applications of these processes to FC power plants, no commercial power plant has as yet been delivered with the capability to use these fuels. Further development of heavier fuel processes is needed to exploit the benefits of FC technology more widely.

\section{IX-1.1C. Power Conditioning}

Fuel-cell stacks produce DC power which must be converted to alternating current at the voltages associated with typical building-distribution systems and utility grids. To perform this function, solid-state power conditioners, which are generally similar to those used in uninterruptible power systems (UPS) or adjustable speed motor drives, are employed. The FC presents, however, a unique combination of demands which require very effective application of the solid-state devices for success. FC applications involve more stringent requirements for high efficiency and lower DC input voltages than are needed in most other applications. FC applications also involve either parallel operation with the utility grid or supplying grid-quality electricity to a load that is independent of the utility grid. For applications parallel with the utility grid, the power conditioner must include functions to protect the FC from voltage disturbances on the grid and to protect the grid and line-service personnel from improper operation of the FC; the FC must maintain output power over wide variations in the grid voltage to avoid nuisance disconnects. For grid-independent applications, excellent voltage regulation and automatic response to fault and motor-starting conditions imposed by the load are required. For both grid-independent and grid-connected applications, both real power and reactive power must be supplied. This combination of technical requirements is as 
challenging or more challenging than most other power-conditioning applications, particularly when the need for reducing costs is considered.

Advances in power semiconductors have been dramatic, particularly during the last decade. Power semiconductor switches have evolved from silicon-controlled thyristors, which required significant auxiliary circuitry and power to accomplish the switching function at relatively low speeds, to Bipolar Darlington Transistors and then to Insulated Gate Bipolar Transistors which accomplish the switching function at high speeds with minimal parasitic power requirements and minimal auxiliary circuitry. For FCs with higher current and voltage ratings, Gate Turn-off Thyristors provide similar advantages. Figure IX-1.4 shows the improvements in power-conditioner sizes and costs which have been achieved in recent $200-\mathrm{kW}$ power-conditioner systems. The power semiconductor devices are now approaching the characteristics of an ideal switch and future developments are expected to result in reduced conduction losses, increased ratings and increased integration of power and control functions. The control logic, which is used to provide the fundamental control and protection functions, has also been advancing rapidly over the past decade and these advances have been important in achieving the illustrated cost reductions. All of the advances are critical to improvement in the characteristics of an $\mathrm{FC}$ power plant.

As advances in the FC stack are achieved, it is quite likely that even lower DC voltages will be preferred for power plants rated at less than $1 \mathrm{MW}$, thereby making the power-conditioner cost-reduction and efficiency-improvement challenge even more difficult. Accordingly, aggressive pursuit of the application of improved power semiconductors and control logic to the difficult FC application is required in continued cooperation with power-electronics suppliers and manufacturers of power semiconductors. In addition, work with IEEE and standards organizations is needed to facilitate installation approval and to reduce installation cost. The overall installed cost of 


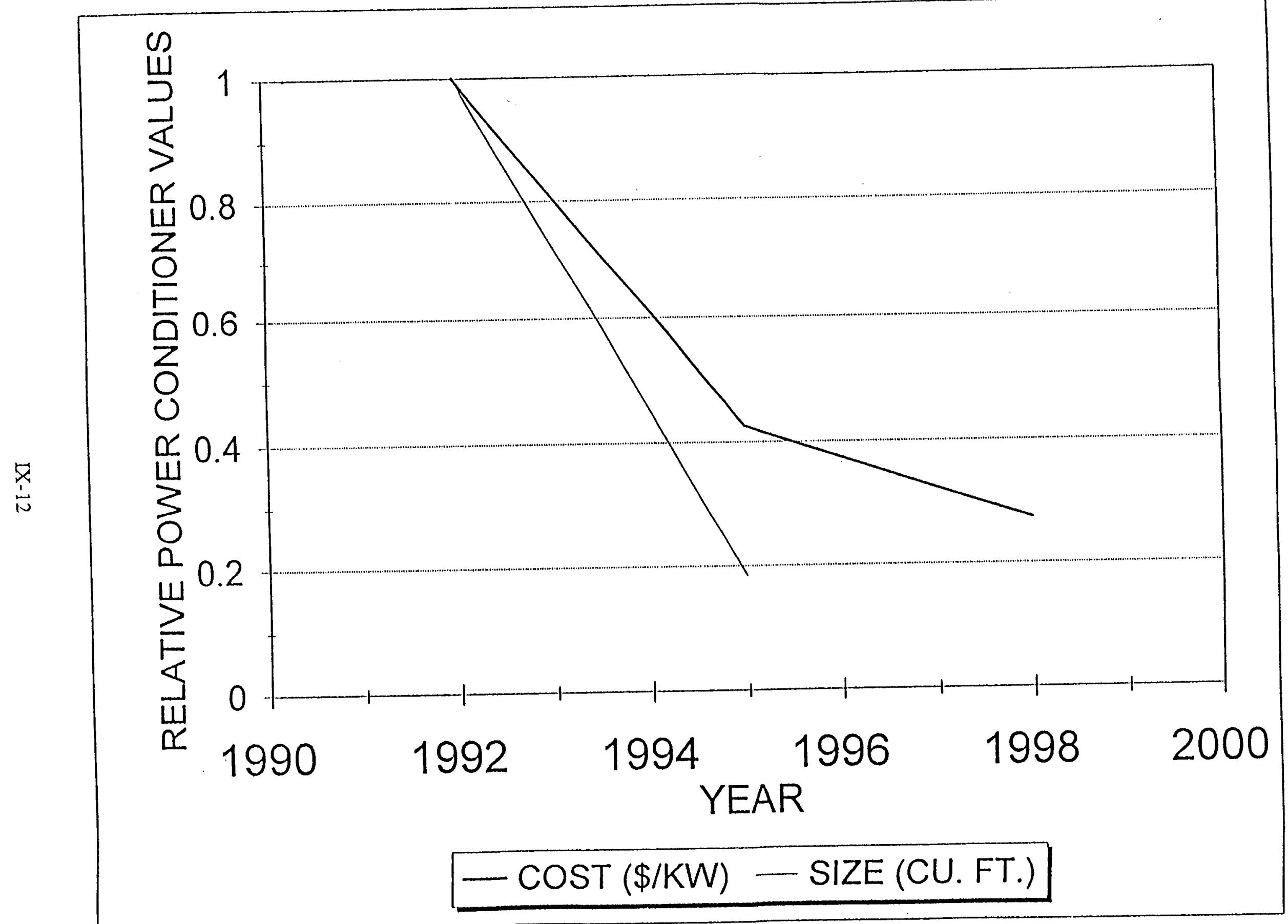

Fig IX-1

Power-ronditinner imnrovement nrniections for IFC PAFC suctems 
the FC power plant can be reduced if widespread approval of the internally provided protection functions can be secured. Currently, some electric utilities require external protection equipment (which duplicates the functions provided as part of the powerconditioner control) at considerable additional cost. Standards activities, as well as adoption of the standards by individual utilities, are required to eliminate this costly duplication. An additional activity involves the ability to make connections to the grid or customer load without using an isolation transformer on the output of the power plant. The transformer adds size, cost and inefficiency to the power plant. Studies which evaluate the need for an isolation transformer and define the requirements for eliminating this hardware, followed by appropriate standards activities, would provide significant improvement in power-plant economics.

\section{IX-1.1D. Ancillary Systems and Power-Piant Assembly}

In addition to the major components discussed in Secs. IX-1.1A to IX-1.1C, a complete FC power plant requires ancillary subsystems and components to provide thermal management, air supply, water recovery and treatment, start-up energy, and system-control functions. This equipment, together with the major components, must be connected with plumbing and wiring, insulated and installed in a weather-proof enclosure. The ancillary equipment and power-plant assembly constitute a significant portion of the power-plant weight, size and initial cost. The controller provides the customer interface for operation and forced-outage diagnostics. Furthermore, historically, the ancillary equipment constitutes the major sources of scheduled maintenance and forced-outage maintenance effort. A number of advances have been made in the ancillary equipment during the last decade as a result of cooperative efforts with ancillary-equipment suppliers to establish requirements consistent with commercial practice and to incorporate advances in these components. Perhaps the most important is improvement in reliability. In the $40-\mathrm{kW}$ field-test activity conducted in the mid-1980s, 
ancillary equipment problems resulted in raw availability of $65 \%$ with availability corrected to commercial practice of $85 \%$. The early stages of operation of the PCTM 25 power plant in the past two years have resulted in a fleet availability of $95 \%$ for full commercial practice conditions. Associated with these availability figures, there has been marked improvement in operation time. Whereas the longest continuous run in the $40-$ $\mathrm{kW}$ program was $2165 \mathrm{~h}$, two units of the PCTM 25 fleet have already exceeded $6000 \mathrm{~h}$ of continuous operation. The improved PC ${ }^{\mathrm{TM}} 25$ power-plant model to be introduced in 1995 has a reduction in the number of mechanical ancillary components by $25 \%$ compared to the initial PCTM25. Further improvements are expected.

Ancillary system improvements have resulted from better approaches to control actuation, heat-exchanger technology, specification of heat exchangers, controller technology (which takes advantage of personal computer advances), and pumps and valves. The power-plant assembly components and cost have benefited from value engineering based on extensive and continuing manufacturing experience. Figure IX-1.5 illustrates the improvements in major heat-exchanger weights between the initial PC ${ }^{\mathrm{TM}} 25$ and those currently in production. Figure IX-1.6 illustrates the overall cost-improvement trend for ancillary systems and the power-plant assembly.

The ancillary equipment continues to represent an opportunity for reduced cost and improved reliability and especially for improvements in servicing cost. A key focus in this area is the water-treatment system, which removes impurities from the water recovered in the FC exhaust and the blow down of the thermal-management system. Improvements in both of the systems which create the impurities and remove them are recommended to reduce the cost of replacing water-treatment resins along with a reduction in servicing frequency. As confidence and experience level grow, the control system and design requirements for ancillary components will be reduced. These ancillary system components will also benefit from the general development of improved 


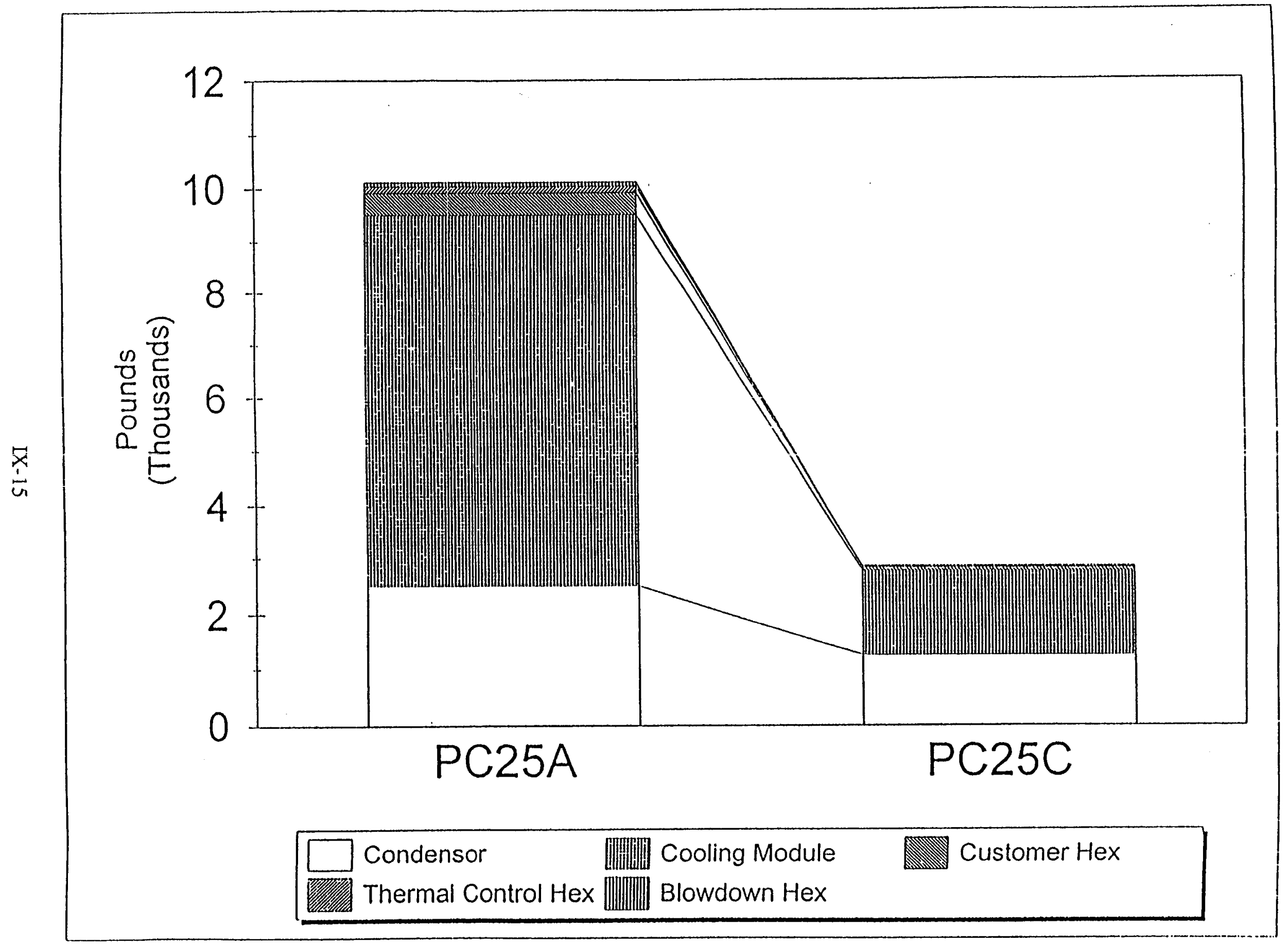

Fin IY-1 5 Heat-erchaneer weioht roductions for IFC PAFC svstems. 


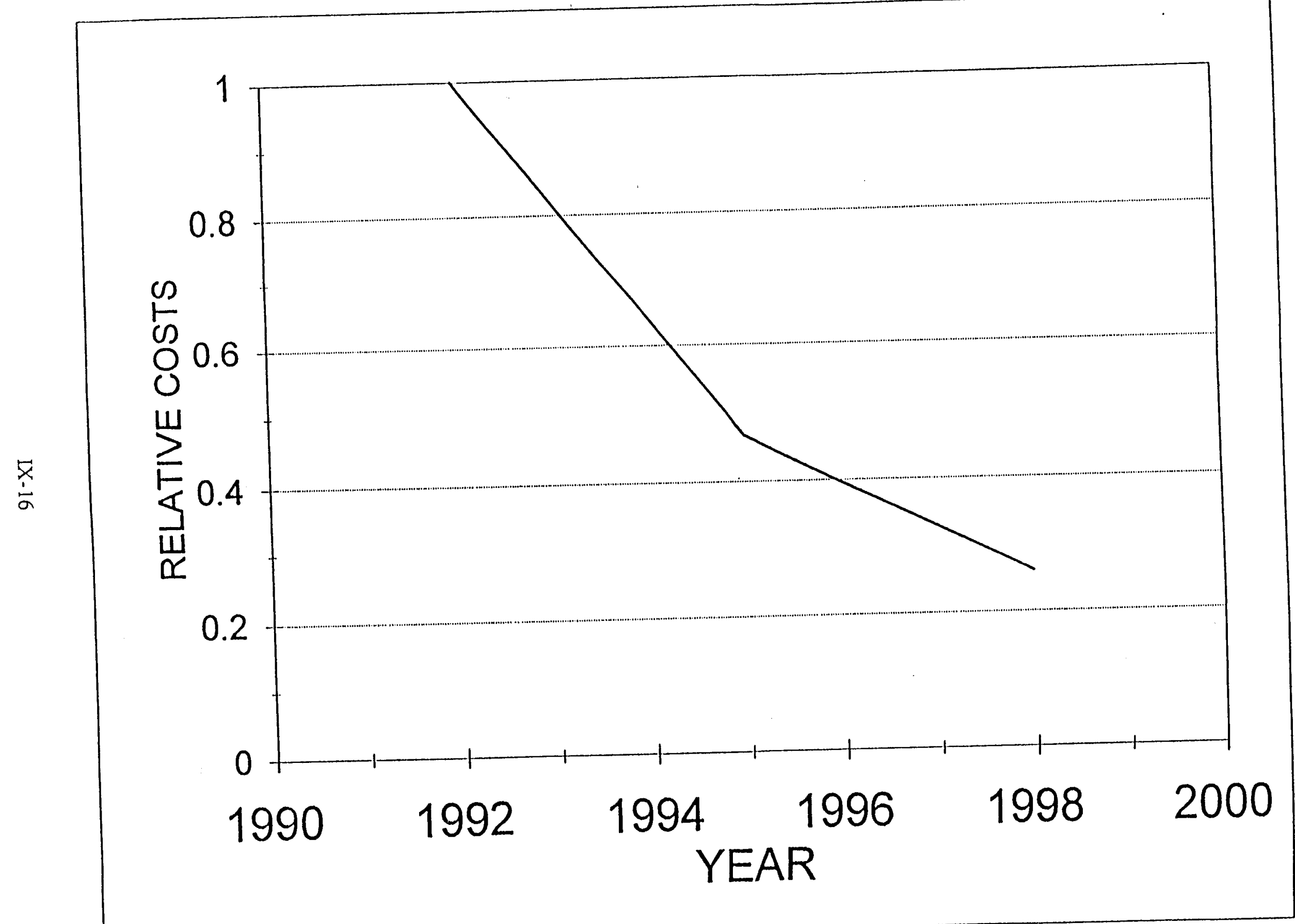


control components, including smart controls and sensors, which will reduce wiring and control-system costs. An aggressive effort to capture these improvements for use in FC system is recommended. 


\section{IX-2. Research to Make Better and Cheaper MCFC Systems}

Issues concerning stack-performance and design, as well as balance of plant features, are discussed in this section.

\section{IX-2.1. Power Density}

MCFC cell performance is compared with that of other current and projected FCs in Fig. IX-2.1. The power density of presently available MCFC designs under standard conditions is approximately $0.123 \mathrm{~W} / \mathrm{cm}^{2}$, i.e. $0.75 \mathrm{~V}$ at $165 \mathrm{~mA} / \mathrm{cm}^{2}$ when using reformed NG as fuel. This power density compares unfavorably with other utility fuel cells in the higher current-density range above $200 \mathrm{~mA} / \mathrm{cm}^{2}$. Cost reduction of the MCFC stack requires raising the power density significantly by increasing the current density to $250-300$ $\mathrm{mA} / \mathrm{cm}^{2}$ and decreasing both ohmic and polarization losses. Power-density goals of Japanese and U.S. developers are nearly double the present value. Japanese developers have adopted goals ranging from 0.18 to $0.225 \mathrm{~W} / \mathrm{cm}^{2}$. The latter value $\left(300 \mathrm{~mA} / \mathrm{cm}^{2}\right.$ at $0.75 \mathrm{~V}$ ) corresponds approximately to the dashed line in Fig. IX-2.1. Performance goals considered achievable by U.S. developers a few years ago (1988-90) are shown in Table IX-2.1.1

Table IX-2.1. Power densities projected by U.S. MCFC developers in $1988-90 ;{ }^{1}$ the arrows refer to performance goals for a later time frame.

\begin{tabular}{c|c|c|c}
\hline Power Density & ERC & IFC & MC-Power \\
\hline $\mathrm{W} / \mathrm{ft}^{2}$ & 104 & $\begin{array}{r}150 \\
\rightarrow 200\end{array}$ & 165 \\
& & $\rightarrow 250$ & \\
\hline $\mathrm{W} / \mathrm{cm}^{2}$ & 0.112 & 0.161 & 0.160 \\
& & $\rightarrow 0.215$ & \\
& & $\rightarrow 0.267$ & \\
\hline
\end{tabular}

\footnotetext{
${ }^{1}$ M.A. Cobb and K. Meacham (Michael A. Cobb \& Company), "Technical and Economic Assessment of Molten Carbonate Fuel Cell Manufacturing Cost," EPRI Report TR-101525, EPRI, Palo Alto, CA (October 1992).
} 


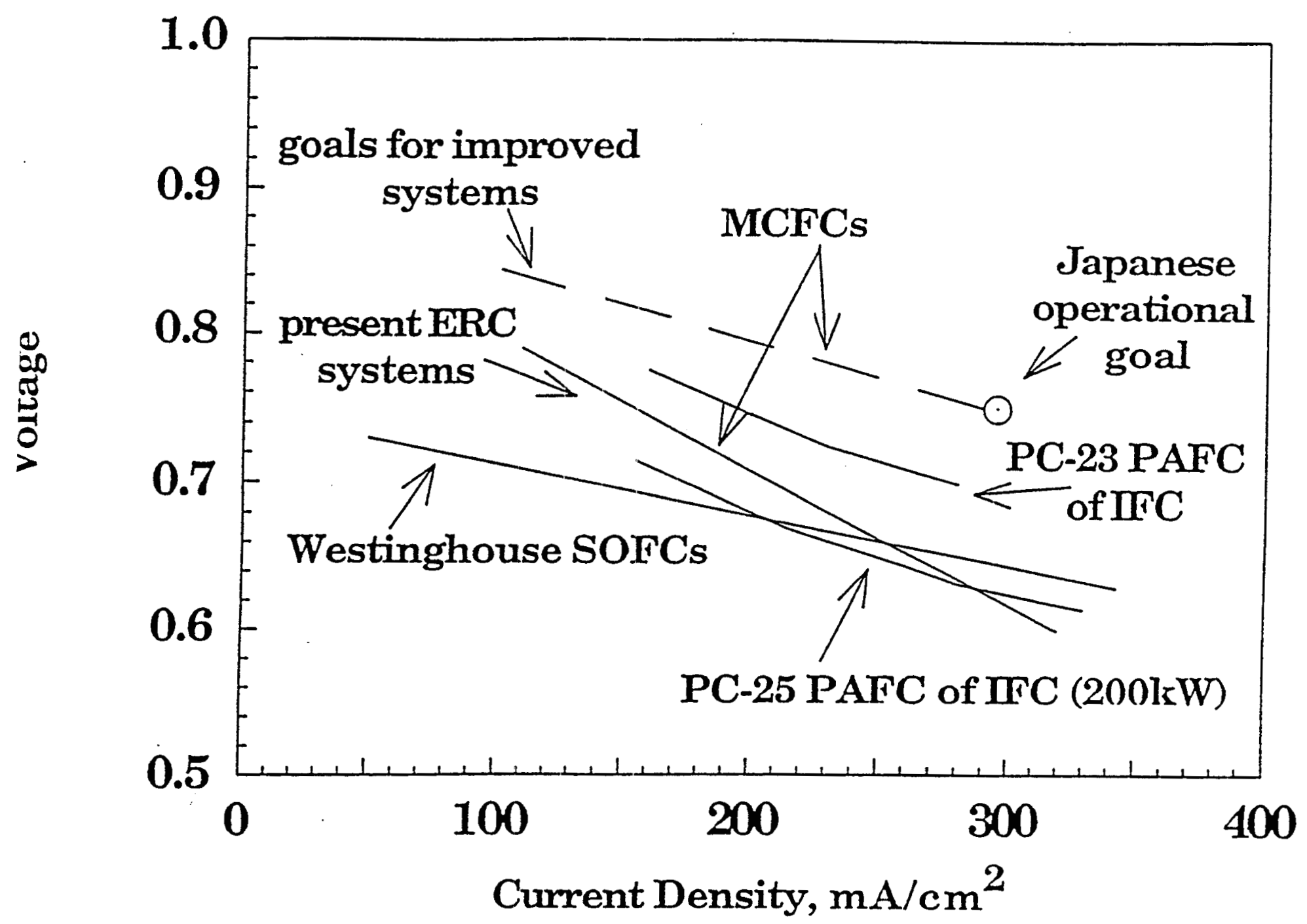

Fig. IX-2.1. Present and anticipated voltage vs current density curves for FC stacks. This summary curve includes information from different sources with greatly different degrees of maturity (e.g., thousands of hours of operation for the $\mathrm{PC} 25^{\mathrm{TM}}$ and relatively limited testing for some of the other systems). 
Increases in power density result from improved choices of operating conditions such as pressurized operations. Presently available information ${ }^{2}$ indicates that the performance gain with increased pressure is greatest in the 1-3 atma pressure range, mostly caused by a decrease of cathode polarization. The performance gain becomes progressively less with higher pressures. The effect of operating pressure on the performance of single cells is illustrated in Fig. IX-2.2, which summarizes a large number of data for two types of cells tested by Japanese developers. ${ }^{3}$ Unfortunately, pressures greater than 3 atma may be necessary to achieve power densities of the magnitude indicated as operational goals.

When pressurized operation is used, cathode $\mathrm{NiO}$ dissolution is a potentially serious issue affecting lifetime since it has been shown to cause long-term performance decline in single cells, as is discussed in Sec. IX-2.2.

Not all MCFC developers aim to use pressurized operation. MCFCs employing internal reforming (pioneered by Energy Research Corporation) will be operated at or only slightly above atmospheric pressure. A high overall efficiency is achieved in internal reforming MCFC (IRMCFC) systems by using a combination of internal reforming and anodic oxidation within the same stack. Indirect internal reforming (IIR) stacks have separate reformer plates at regular intervals in the stack, typically one for every 5 or 6 cells; ${ }^{4}$ direct internal reforming (DIR) combines reforming and anodic oxidation in each cell, although these are usually separated spatially so that the reforming catalyst and its support are not wetted by molten carbonate, i.e. not covered by an electrolyte film. 5

2J. R. Selman, "Research, Development, and Demonstration of Molten Carbonate Fuel Cell Systems," in L.J.M.J. Blomen and M.N. Mugerwa eds., Fuel Cell Systems, Plenum Press, London (1993).

${ }^{3}$ Y. Mugikura, T. Abe, T. Watanabe, and Y. Izaki, "Development of a Correlation Equation for the Performance of MCFC," CRIEPI-EW91002, Central Research Inst. for the Electric Power Industry, Yokosuka, Japan (1991).

4J. Tanaka, A. Saiai, S. Sakurada, T. Nakajima, Y. Miyyake, T. Saitoh, M. Sasaki, and H. Yanaru, "Design of 30-kW Class DIR-MCFC System," in Proc. Third Intl. Symp. Carbonate Fuel Cell Technology, p. 37, D.A. Shores, H. Maru, I. Uchida, and J.R. Selman eds., PV93-3, The Electrochemical Society, Inc., Pennington, NJ (1993).

5J. Ohtsuki, T. Seki, S. Takeuchi, A. Kusunoki, A. Sasaki, H. Urushibata, and T. Murahashi, "Development of Indirect Internal Reforming Molten Carbonate Fuel Cell," p. 48 in Ref. 4. 


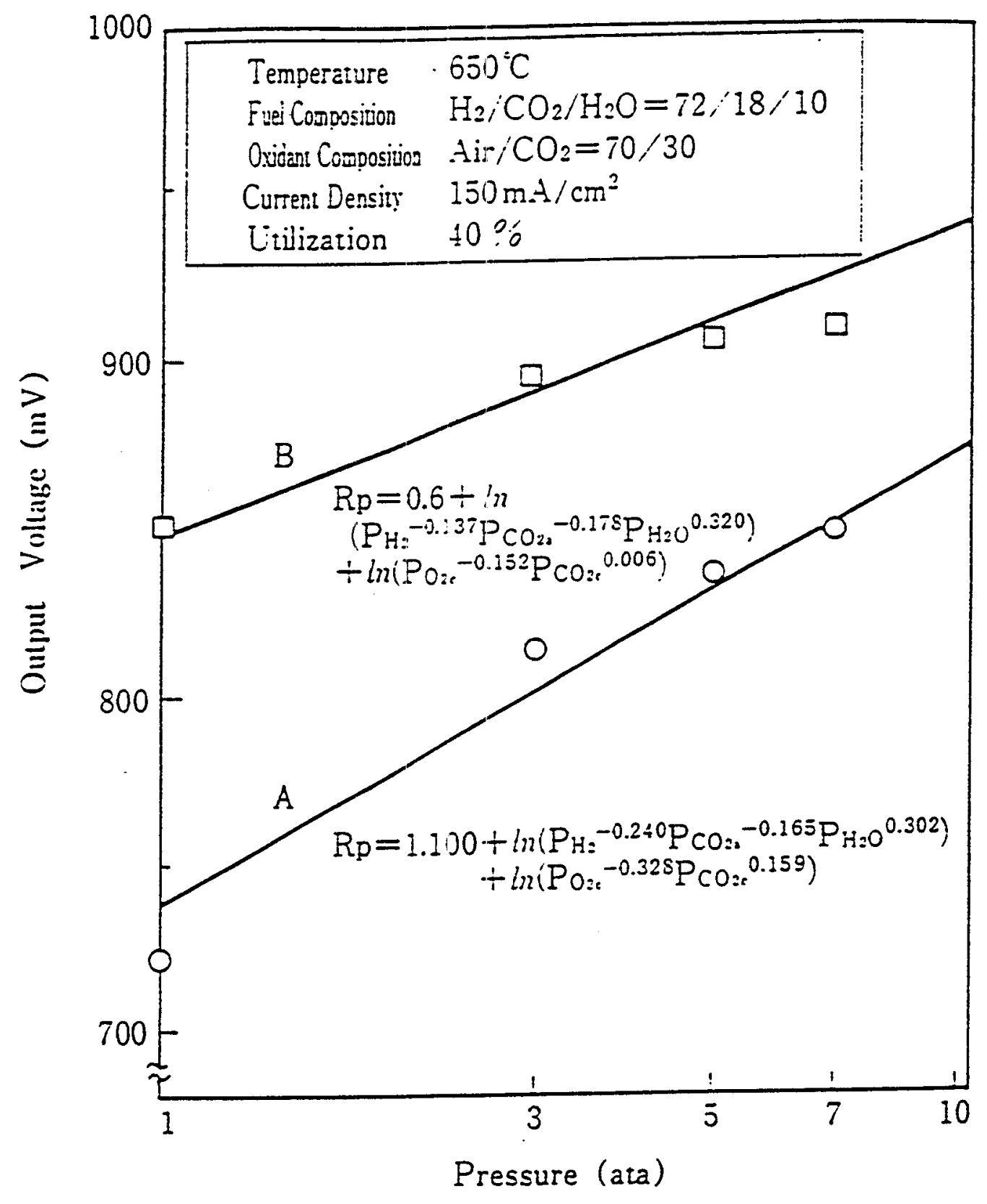

Fig. IX-2.2. Effect of operating pressure on the performance of two types of MCFC single cells as given by Japanese investigators. ${ }^{3}$ 
In the case of IIR and DIR stacks operated under atmospheric pressure, as well as for pressurized stacks, the development of improved components is an absolute prerequisite for increased power density. Table IX-2.2 shows approximate voltage-loss contributions under standard operating conditions at atmospheric pressure associated with the various cell components. Estimates of improvements possible within a 3-4 year time frame are also shown. Performance improvements will be achieved mainly by reducing cathode polarization and ohmic voltage drop. Other voltage-loss components can only be marginally improved. Much of the applied research necessary for performance improvement is being undertaken by developers as an integral part of their commercialization effort. The improvements relate to components that may have proprietary features. However, generic information of interest to all developers is also needed, including the use of advanced porous electrode models. ${ }^{6,7} \mathrm{~A}$ much stronger base of materials and chemical sciences will be useful in the successful development of highpower-density electrodes with long-term stability. This product-improvement R\&D is described in Sec. IX-2.5.

Table IX-2.2. Approximate voltage-loss components in $\mathrm{mV}$ for MCFCs at $165 \mathrm{~mA} / \mathrm{cm}^{2}$ when operating on reformed $\mathrm{NG}$ at $1 \mathrm{~atm}$ and $650 \mathrm{C}$ (estimates of U.S. developers).

\begin{tabular}{l|c|c}
\hline Loss Component & $\begin{array}{c}\text { State of the Art } \\
\text { MCFCs }\end{array}$ & $\begin{array}{c}\text { Future } \\
\text { MCFCs }\end{array}$ \\
\hline Ohmic & 50 & 25 \\
Cathode & 120 & 60 \\
Anode & 60 & 50 \\
Nernst & 65 & 65 \\
\hline Total & 295 & 200 \\
\hline
\end{tabular}

${ }^{6}$ G.L. Lee, J.R. Selman and L. Plomp, J. Electrochem. Soc. 140, 390, (1993).

${ }^{7}$ E. Fontes, C. Lagergren and D. Simonsson, Electrochim. Acta 38, 2669 (1993). 


\section{IX-2.2. Mitigation or Prevention of NiO Dissolution}

In spite of significant research, it remains unclear to what extent the increased pressure needed to obtain increased power density will cause lifetime shortening due to $\mathrm{NiO}$ (cathode) dissolution and nickel precipitation in the electrolyte. Nickel precipitation and cell shorting was identified as a potential life-time issue in single MCFC cells about a decade ago. The chain of events leading from $\mathrm{NiO}$ dissolution via precipitation to the formation of high-ohmic electrical shorts is complicated. It has apparently not been conclusively demonstrated to occur in MCFC stacks, at least during the limited lifetimes (not exceeding $8000 \mathrm{~h}$ ) of present-day stacks.

Extensive research has been carried out on the solubility of $\mathrm{NiO}$ and other oxides in molten carbonate. $8-10$ This study has shown that increased MCFC operating pressure at a constant mole fraction of $\mathrm{CO}_{2}$ definitely raises the solubility of $\mathrm{NiO}$, and a few simplified models for cell lifetime have been based on this result. ${ }^{11,12}$ Other modelers generally attempt to make a connection between $\mathrm{NiO}$ solubility, amount of nickel metal precipitated, and shorting resistance in order to predict cell lifetime. ${ }^{13-15}$ The results of these modeling approaches are widely divergent (see Fig. IX-2.3). NiO solubility is apparently not the

\footnotetext{
${ }^{8}$ K. Ota, S. Misushima, S. Kato, S. Asano, H. Yoshitake, and K. Kamiya, J. Electrochem. Soc. 139, 667 (1992).

9D.A. Shores and Y. Qu, "Dissolution of Oxides in Molten Carbonates," p. 356 in Ref. 4.

${ }^{10}$ M.L. Orfield and D.A. Shores, J. Electrochem. Soc. 136, 2862 (1989).

${ }_{11}$ D.A. Shores, J.R. Selman, S. Israni, and E.T. Ong, "Degradation of NiO Cathodes: Modeling and Experimental Studies," p. 290, Proc. Second Intl. Symp. Molten Carbonate Fuel Cell Technology, J.R. Selman, D.A. Shores, H.C. Maru, and I. Uchida eds., PV 90-16, The Electrochemical Society, Inc., Pennington, NJ (1990).

12J.B.J. Veldhuis, S.B. van der Molen, R.C. Makkus, and G.HJ. Broers, Ber. Bunsenges. Phys. Chem. 24, 947 (1990).

${ }^{13}$ H.R. Kunz and J.W. Pandolfo, J. Electrochem. Soc. 139, 1549 (1992).

${ }^{14} \mathrm{H}$. Kasai and A. Suzuki, "Dissolution and Deposition of Nickel Oxide Cathode in Molten Carbonate Fuel Cell," p. 240 in Ref. 4.

${ }^{15} \mathrm{~S}$. Yoshioka and H. Urushibata, "Life Simulation of Internal Shorting on the Basis of the Deposited Nickel Amount in the Molten Carbonate Fuel Cell Matrix." p. 135. Proc. 34th Battery Symposium in Japan, Hiroshima (Nov. 1993).
} 


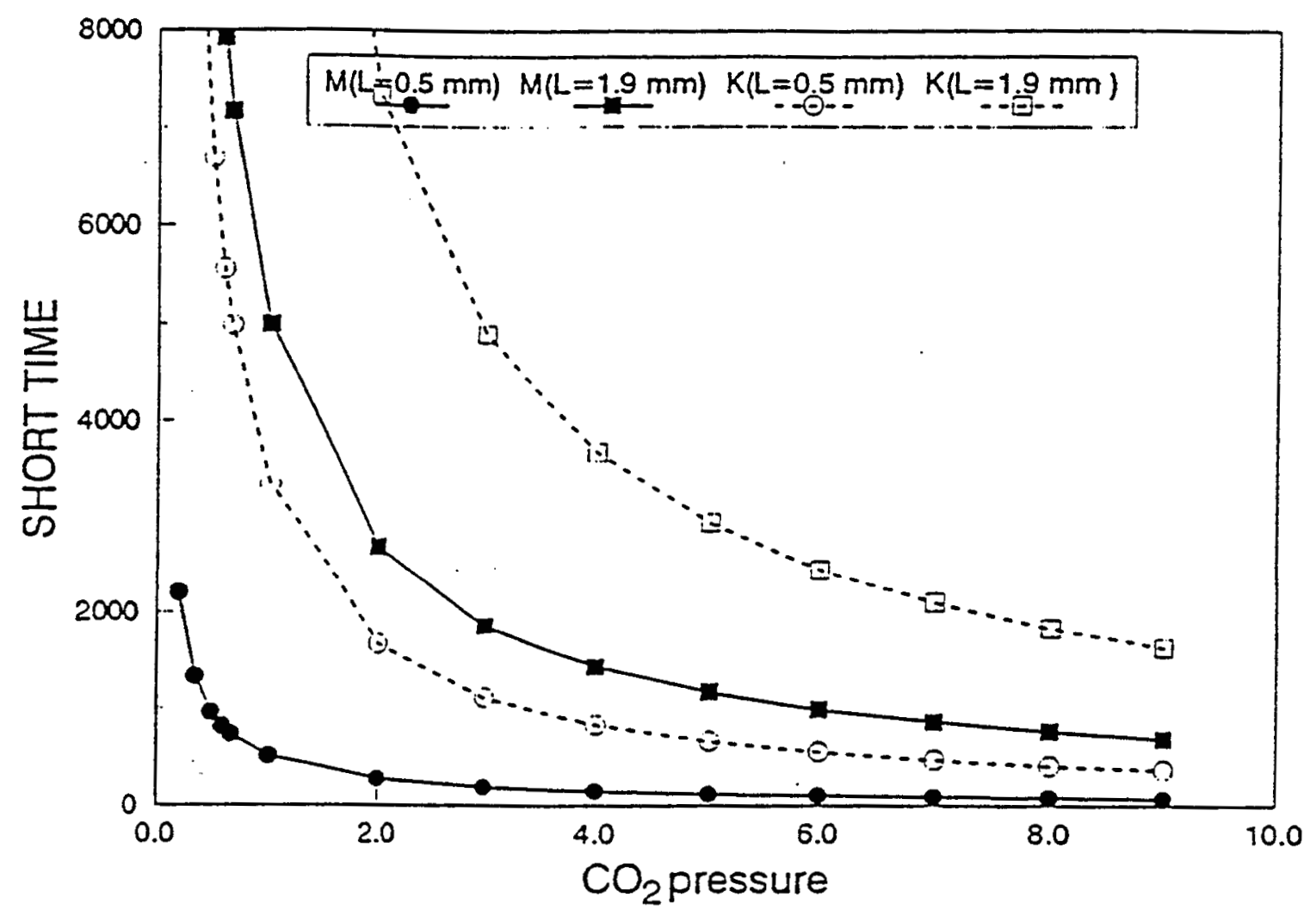

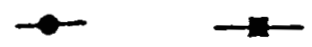

MUGIKURA et al (1994)15

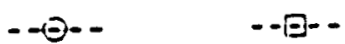

KUNZ \& PANDOLFO (1992)15

Fig. IX-2.3. Predictions of lifetime-to-shorting according to two current models. ${ }^{13,27}$ 
only factor controlling the rate of nickel precipitation. The operating current density and the conditions of the electrolyte tile/matrix (in particular, the porosity, integrity and basicity) appear to play important roles. There is at present no consensus about the mechanism by which these factors affect lifetime and no agreement about the quantitative cost aspects of this effect. Therefore, there is a need for systematic studies to explore and mitigate possible long-term effects of $\mathrm{NiO}$ dissolution since there is little doubt that $\mathrm{NiO}$ will continue to be used as a cathode material in demonstration stacks for the foreseeable future. In addition, alternative cathode materials, the most promising of which have been identified to be $\mathrm{LiCoO}_{2}$ and $\mathrm{LiFeO}_{2}, 16,17$ should be more fully evaluated for practical utilization in cells and stacks.

The phenomena involved in $\mathrm{NiO}$ dissolution, nickel precipitation, particle growth and convection, and shorting should be carefully investigated and quantitative insights concerning their interactions established. Experimental and computational studies should be performed of the phenomena involved. Experimental studies should include not only quantitative analyses of the thermodynamics of metal-oxide dissolution in carbonates, which are now fairly well understood, but also investigations of the kinetics of nucleation and growth or dissolution of isolated particles and particle arrays in molten salts. Also important are studies of the effects of flow fields and electric fields on these particles and particle arrays. The transport properties of dissolved metal species in mixed cationic melts are of special importance and could be investigated by employing computational studies with Monte Carlo techniques to describe the molecular dynamics and to establish the dominant species or configurations of species (using molten salt analogs of complexes in electrolyte solutions) that play a role in the various phases of the dissolution/transport/

${ }^{16} \mathrm{~J}$. L. Smith, G.H. Kucera and A.P. Brown, "Development of Cathode Materials and Structures for the Molten Carbonate Fuel Cell,". p. 226 in Ref. 11.

${ }^{17} \mathrm{~B}$. Bergman, C. Lagergren and A. Lundblad, "Synthesis and Performance of $\mathrm{LiCOO}_{2}$ Cathodes of MCFC," p. 342 in Ref. 4. 
precipitation/accretion/shorting processes. Computational research may also provide insight into the NiO-dissolution process, as demonstrated in recent work at ECN in The Netherlands. ${ }^{18}$ The most useful outcome of such research would be the development of predictive techniques at the molecular level for speciation and transport in the electrolytes.

\section{IX-2.3. Corrosion Protection and Electrolyte Management}

Corrosion of metallic materials in the MCFC stack is mainly of concern for the separator plate and those parts of the BOP that are exposed to carbonate, either by liquid creepage or by condensation of vapor. Corrosion is not only deleterious for the materials in question but also causes changes in electrolyte composition and physical properties that may give rise to electrolyte displacement (e.g., in the wet seal area) and to creepage of electrolyte on corroding surfaces. There is, therefore, an intimate connection between corrosion of metals, the loss of electrolyte and of particular cations (especially $\mathrm{Li}^{+}$) from the electrolyte, and the wetting of metal and oxide surfaces by electrolyte. It has been estimated that only $10 \%$ of the electrolyte loss over a period of 5 years will be due to electrolyte evaporation. The remainder is attributed to corrosion and creepage, although it is not clear how these can be accounted for quantitatively. Individual developers are expending effort to answer these questions, with particular reference to proprietary stack designs. This effort needs a stronger fundamental base of generic research on alloy corrosion in molten carbonate, which would benefit all developers. Such generic research

${ }^{18}$ L. Plomp, R.C. Makkus and G.J.M. Janssen, "MCFC Electrolyte Behaviour: Basic Research and Technology Development." EA 94-2, The Electrochemical Society Inc., Pennington, NJ (1994). 
is taking place ${ }^{19}$ but at a relatively low level of activity compared to that in Japan $20-23$ and some European countries. ${ }^{24}$ A related area of generic research with great potential pay-off in optimizing long-term performance is the capillary behavior (wetting) of corroding and corrosion-resistant surfaces in contact with carbonate films. ${ }^{25}$

As noted, corrosion problems impact primarily on the separator, but apparently also on BOP components such as high-temperature blowers, heat exchangers, and the hardware connecting these to the stack. As would be expected because of differences in design, there is no general agreement on BOP corrosion. Nevertheless, as noted previously, generic research on alloy corrosion in molten carbonate is especially needed in order to understand differences in impact on the BOP. Corrosion of these components could be explored as part of a general research strategy involving the BOP and including the hydrodesulfurizer, inverter, and other components for which long-term performance depends on other factors in addition to corrosion.

The impact of separator corrosion on stack lifetime and system cost is at present difficult to estimate, primarily because not enough data are available from long-term tests. Another reason for caution is that ideas about the most desirable electrolyte composition will probably keep evolving in the course of optimizing the system to achieve satisfactory long-term performance. Although progress has been made recently in understanding the

${ }^{19}$ D.A. Shores and M.J. Pischke, "Hot Corrosion of Current Collector/Separators in Carbonate Fuel Cells," p. 214 in Ref. 4.

20T. Nishina, K. Yuasa, and I. Uchida, "Electrochemical Study of Corrosion Behavior of Iron-Based Nickel and Iron-Based Chromium Alloys," p. 264 in Ref. 4.

${ }^{21} \mathrm{~K}$. Ota, B. Kim, Y. Abe, H. Yoshitake, and N. Kamiya, "Effect of Molten Alkaline Carbonate on the High Temperature Corrosion of Cr," p. 252 in Ref. 4.

22 M. Yanagida, Y. Miyazaki, S. Tanase, K. Tanimoto, T. Kojima, N. Ohtori, and T. Kodama, "The Effect of Alkaline Carbonate Addition on High Temperature Corrosion of Separator Material and Electrolyte Consumption for MCFC," p. 230 in Ref. 4.

${ }^{23} \mathrm{~K}$. Takeuchi and N. Koura, "Study on Corrosion Behavior of Fe Based Alloys in Molten Carbonates (2)," p. 131 in Ref. 15.

24J.P.T. Vossen, L. Plomp and J.H.W. de Wit, "Corrosion of Nickel in Molten Carbonate," p, 278 in Ref. 4.

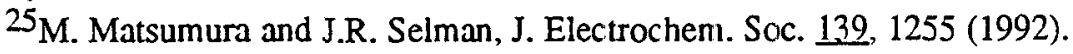


mechanism of alloy corrosion in Li-K carbonate (Fig.IX-2.4), ${ }^{26}$ these results may not be immediately transferable, for example, to $\mathrm{Li}-\mathrm{Na}$ carbonate. In fact, much of the fundamental basis for systematic interpretation of the corrosion mechanism is missing. This last statement applies to the needed data base for understanding the solubility characteristics of nickel, iron, chromium, and other alloy components in melts of variable composition and basicity, as well as the solid-state chemistry of transition metal oxides and their stable and metastable phases in contact with the carbonate melt.

Another area related to corrosion and electrolyte management is the long-term performance of direct-internally-reforming MCFCs (DIR-MCFC). The lifetimes of the reforming catalyst in direct contact with electrolyte, either by vapor condensation or by liquid creepage, are determined by corrosion processes that especially affect catalyst supports such as $\mathrm{MgO}$ or $\mathrm{LiAlO}_{2}$. Although much of the relevant applied research on deactivation is tied to particular DIR designs, there is a need for better fundamental understanding of forces that drive wetting and corrosion at metal/metal-oxide interfaces in contact with gas atmospheres of varying composition (in the present case, varying $\mathrm{H}_{2} / \mathrm{H}_{2} \mathrm{O}$ content).

\section{IX-2.4. Manufacturing Techniques}

The cost of the separator material is not a dominant element in determining stack cost. According to an EPRI-sponsored study, ${ }^{1}$ it represents $13-18 \%$ of the stack cost (20$29 \%$ of the materials cost). Estimates of various cost components according to U.S. developers are summarized in Ref.1. It is apparent from these data that efforts at cost reduction should target all materials used in the stack as well as the stack structure. Nevertheless, the separator is a conspicuous and convenient initial target for cost reduction.

\footnotetext{
${ }^{26}$ C.Yuh, M. Farooque and H. Maru, "Selection of Materials for Carbonate Fuel Cell Applications," Workshop Materials-Science Issues Relating to High-Temperature Fuel Cells, La Jolla. CA (March 24, 1994).
} 


\section{SCALE GROWTH IN CATHODE ATMOSPHERE}
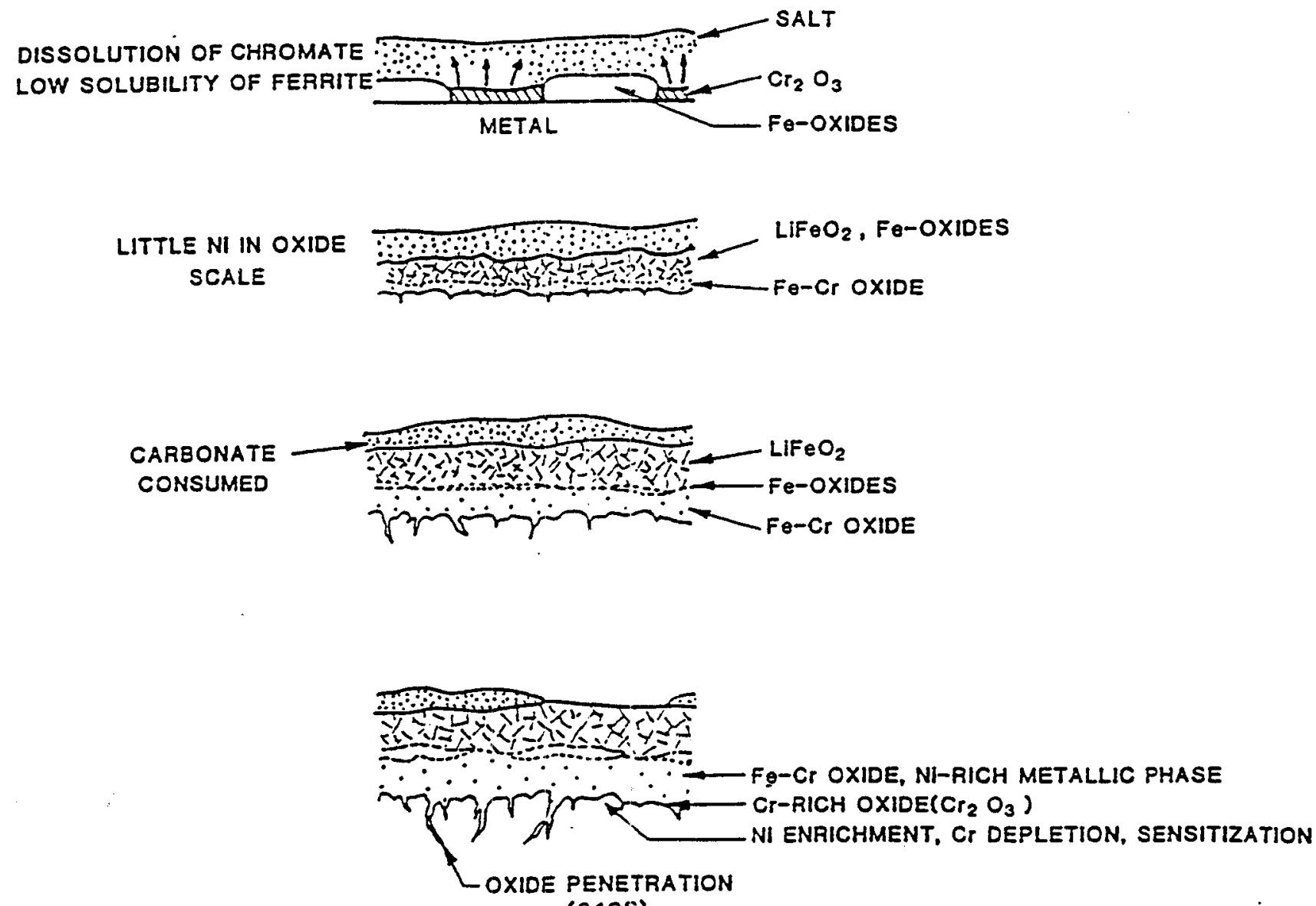

(3 105)

Fig. IX-2.4. Scale growth on Ni-Cr steel in molten carbonate as a function of cathode atmosphere. Reproduced from C.Yuh, M. Farooque and H. Maru, "Selection of Materials for Carbonate Fuel Cell Applications," Workshop Materials-Science Issues Relating to High-Temperature Fuel Cells, La Jolla, CA (March 24, 1994). 
It should also be noted that Japanese developers report significantly higher cost contributions than U.S. developers for the separator ${ }^{27}$ (compare Fig. IX-2.5).

It appears that the present thickness of the separator $(0.015-0.020$ inch or 0.375 $0.60 \mathrm{~mm}$ ) is the optimal thickness. Further reduction would cause complications in the manufacturing process, such as difficulties in keeping cell-to-cell and component-tocomponent distances uniform within specifications. The use of too thin a separator may lead to an inadequate thickness for the protective oxide layer on the cathode side, which depends for its formation on alloy constituents such as $\mathrm{Mn}, \mathrm{Cr}$ and $\mathrm{Fe}$.

An important part of the stack-manufacturing cost is attributed to the necessity of using nickel-clad materials on the anode side of the separator and the aluminizing treatment of edges and feed-throughs of the separator to prevent wet-seal corrosion. ${ }^{28}$ Though nickel cladding of the anode side of the separator is considered inevitable, decreasing its cost is highly desirable. The hot-rolling technique used thus far is judged to be acceptable, provided the developer can exert adequate control over the manufacturing conditions. The thickness of the nickel layer, which used to be several mils in earlier stages of development, should not exceed 0.002 in. To accomplish this goal without significant nickel loss due to diffusion into the substrate, a diffusion barrier may have to be used. Customized alloys of the types being developed in Japan are considered to be less promising, according to U.S. developers, since they are costly to manufacture and may still not provide adequate protection over the long term. Nevertheless, there may be a need eventually to reformulate the stainless steel used for the separator so as to maintain an optimal balance between manufacturing cost and effective lifetime, as Japanese and European developers have suggested.

${ }^{27}$ Y. Mugikura, Y. Ito and J.R. Selman, "Status of MCFC Technology," to appear in J. Power Sources (1994).

${ }^{28}$ S. Sato, "Development of Internal Manifolding Stack," p. 137 in Ref. 17. 


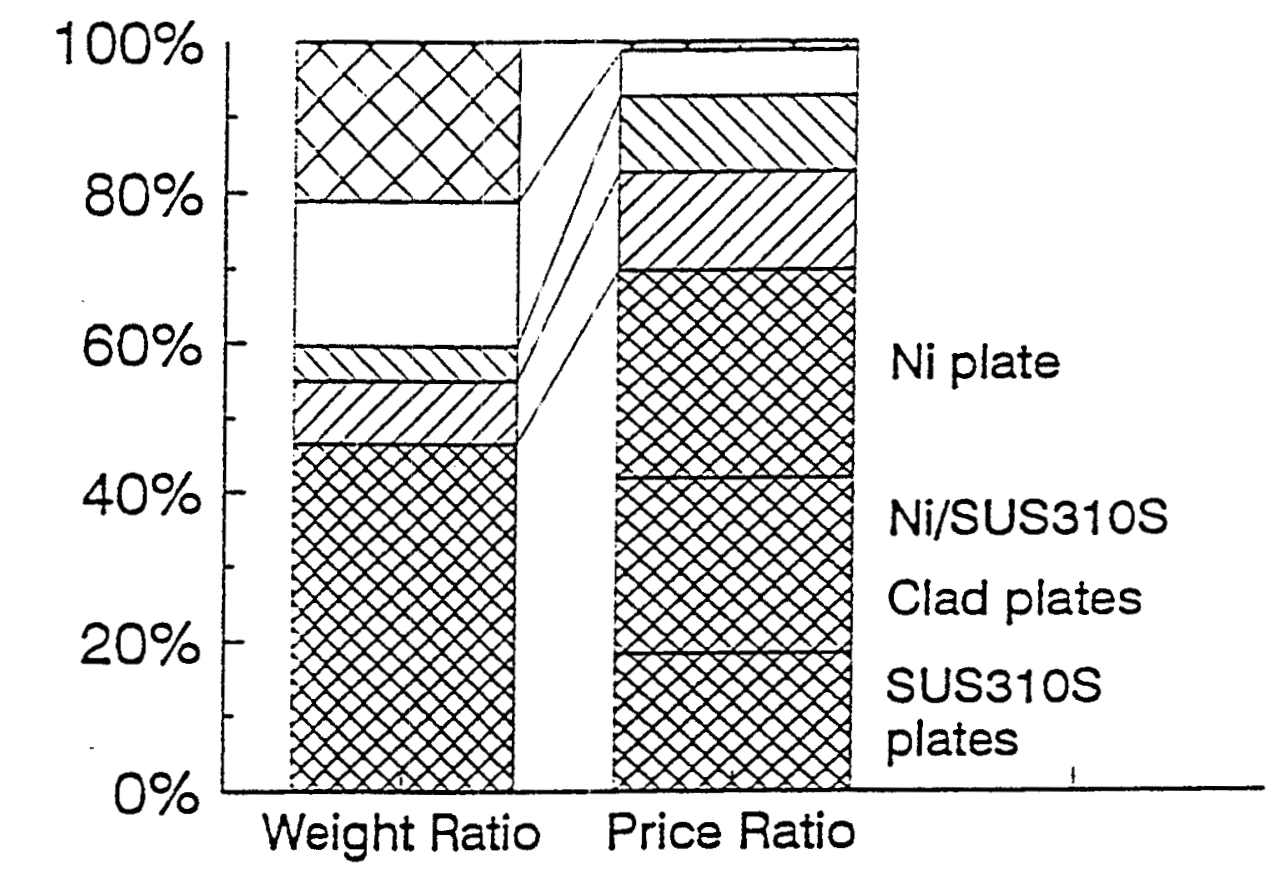

$\otimes$ Separator $\square$ Electrodes $\nabla$ Matrix $\square$ Belongings $\square$ Vesse!

Fig. IX-2.5. Materials cost contributions to the MCFC stack according to Japanese MCFC developers. 27 
Based on its thermodynamic stability, copper could be substituted for nickel in the cladding of the separator on the anode side; copper could also be substituted for nickel as an anode material since its kinetic characteristics are not greatly inferior to those of nickel. IGT has made extensive studies and tests of this option, including tests of nickel-alumina composite materials for the anode. An important question that remains to be resolved is whether the efficient recycling of spent MCFC materials is possible when copper is substituted for nickel, since small amounts of copper tend to degrade stainless steel as the result of alloying during heat treatment in the course of recycling.

Alternative techniques to aluminize the wet-seal areas of the separator plate are being investigated by developers. Reviews of such techniques are available. 27,28 The choice of an optimal technique is closely tied to the specific design of the separator plate in external manifolding stacks or the separator-plate assembly in internal manifolding stack designs. A shared need is to establish a better understanding of the adhesion of coatings to the substrate, which is controlled by the growth and interdiffusion of oxide layers of aluminum and transition metals. These are initially formed in a gas atmosphere and are subsequently transformed in contact with the electrolyte leading to the formation of $\mathrm{LiAlO}_{2}$, $\mathrm{LiFeO}_{2}$. From a fundamental viewpoint, this process has much in common with the corrosion processes discussed in Section IX-2.3.

Any useful manufacturing technique must be easy to automate. Manufacturing-cost reductions require automated production, with the goal that typically less than $10 \%$ of the production costs are labor costs. There must be extensive automation of assembly jobs. Fortunately, automation is facilitated by inherent scalability of the MCFC. Advanced assembly procedures will require elimination of separate treatments in separate ovens or furnaces and elimination of many batch operations. Therefore, there is a requirement for the development of special-purpose facilities for continuous tape-casting, drying and sintering. 


\section{IX-2.5. Research Objectives and Needs}

The product-improvement studies needed to achieve the desired performance improvements may be classified, from the viewpoint of developers, as short-term and longterm research. Both of these will benefit from parallel efforts of a more fundamental kind, as will now be outlined.

\section{A. Short-term Research (3-year Horizon)}

The following is a preferred list for near-term investigations: (i) Electrolyte optimization, e.g., exploration of $\mathrm{Li}-\mathrm{Na}$ carbonate mixtures, possibly with additives, to replace the Li-K carbonate presently used. (ii) Optimization of cathode morphology, especially by increasing the cathode surface area by perhaps a factor of 100 , thereby making it comparable to that used in PAFCs and other low-temperature cells. (iii) Stabilization of cathode morphology to prevent long-term performance decline due to sintering and creep.

\section{B. Long-term Research (5-10 year Horizon)}

Over the longer term, product improvements require the following investigations: (i) Development of cathode materials to replace $\mathrm{NiO}$ by a less costly and perhaps less soluble or easily reducible cathode material. Research during the past several years has led to plausible claims for $\mathrm{LiCoO}_{2}$ and doped $\mathrm{LiFeO}_{2}$ as alternative cathode materials. 6,17 More work needs to be done with respect to electrode/matrix structure, pore-size characteristics, and electrolyte filling before it will become possible to apply these materials widely in MCFC cells and stacks. (ii) Alternative fabrication techniques are needed for the wet-seal protection coatings used in the separator plate. 


\section{Fundamental Research}

In addition to near-term and long-term product-improvement $R \& D$, there is a need for fundamental research to accelerate each of the following: (i) The development of predictive techniques suitable for screening various mixed oxides or doped oxides, as well as non-oxide solutes, with respect to solubility, transport properties and reducibility, in electrolytes of variable cationic $\left(\mathrm{Li}^{+}, \mathrm{Na}^{+}, \mathrm{Ba}^{2+}\right.$, etc.) and anionic $\left(\mathrm{CO}_{3}{ }^{2-}, \mathrm{OH}^{-}\right)$ compositions. (ii) Understanding of the mechanisms by which structures and surfaces change in a molten-salt environments and methods to minimize the changes by appropriate molecular engineering, under well-defined conditions of synthesis leading to film formation, coating, particle sintering, etc. (iii) Understanding the basic phenomena involved in dissolved metal transport and precipitation in carbonates and similar melts, as well as particle accretion/translation and shorting. This fundamental research should take account of the thermodynamics of metal-oxide dissolution in carbonates while emphasizing primarily the kinetics of nucleation and growth/dissolution of isolated particles and particle arrays in molten salt together with the effects of flow fields and electric fields on such particles and particle arrays. Speciation in mixed cationic melts would also be an objective, especially in combination with computational studies. (iv) Gaining insight into the NiOdissolution process at a molecular scale by using computational experiments with molecular dynamics and Monte Carlo techniques. These should be directed at identifying the dominant species or configurations of species that play roles in various phases of the dissolution/transport/precipitation/accretion/shorting processes. The development of predictive techniques is again an important objective. (v) Development of general but practically useful knowledge about the differences between sintering and metal-creep processes in contact with molten salt electrolyte as distinguished from those in air, which have been explored extensively during the last decades in connection with powder metallurgy. (vi) Developing a fundamental basis for systematic interpretation of alloy 
corrosion in molten salt and, in particular, in molten carbonates, where the effect of the gas atmosphere is dominant. Such research should combine experiments with modeling of potential and current distributions. A data base is needed for the solubilities of nickel, iron, chromium, and other alloy components in melts of variable composition and basicity. Also required is systematic work on the solid-state chemistry of transition metal oxides and their stable and metastable phases in contact with carbonate melts. (vii) Understanding and controlling the interaction of wetting, migration and corrosion in alloy corrosion by using both experiments and modeling, as in corrosion-protection modeling. This research should identify the forces that drive wetting and corrosion at metal/metal-oxide interfaces in contact with gas atmospheres of varying composition. (viii) Gaining insight and predictive knowledge concerning the behavior of the reforming catalyst in direct contact with electrolyte, either by vapor condensation or by liquid creepage. The interactions of corrosion processes (especially those affecting such catalyst supports as $\mathrm{MgO}$ or $\mathrm{LiAlO}_{2}$ ) and catalyst poisoning are of special interest. This research should identify the forces that drive wetting and corrosion at metal/metal-oxide interfaces in contact with gas atmospheres of varying $\mathrm{H}_{2} / \mathrm{H}_{2} \mathrm{O}$ compositions.

\section{IX-2.6. Manufacturing Issues for MCFCs at ERC*}

In 1992, ERC placed into operation a wholly-owned and privately financed fuelcell-stack manufacturing facility rated at about $10 \mathrm{MW} / \mathrm{yr}$ on a three-shift basis. The manufacturing yields since 1992 to the present have increased from 30\% to above $90 \%$ with an improvement in acceptable tolerance levels. For certain individual repeating components with the same machinery, an order of magnitude productivity-level increase has been reached. If all repeating components can be developed to this same level, which is a reasonable goal, then ERC will have achieved its projected manufacturing goals of material costs representing $80 \%$ of the total manufactured cost.

\footnotetext{
* Submitted by B.S. Baker.
} 
Our development activities are focused on improving the manufacturing processes while reducing materials contents, both of which have the corollary effect of improving power density.

At present, non-repeating components, which are mostly out-sourced, require additional cost reductions and efforts to achieve these lower costs but both design improvements and vendor development are in progress.

\section{Balance of Plant MCFC Issues}

For all fuel-cell systems using hydrocarbon fuels such as NG, the balance of plant (BOP) represents the bulk of the cost, ranging from 65 to $85 \%$ of total system cost. In general, the lower the temperature of the fuel cell, the more complex and expensive the BOP becomes.

In the MCFC system, it is possible to simplify the BOP greatly by integrating the external hydrogen-generation equipment into the fuel-cell stack itself, either directly or indirectly. Both approaches have been tested in stacks for more than 10,000 hours and post-test analyses in combination with proper stack design suggest that a five-year life is achievable for both approaches. By eliminating the external fuel-processing equipment, a major cost item can be eliminated. Moreover, using the stack waste heat to sustain the endothermic reforming reaction eliminates other heat-exchange equipment while simultaneously providing cell cooling. The in situ cooling reduces parasitic power and cost of the air-cooling equipment.

Even with these benefits and a simplified system, ERC estimates that the BOP, including the inverter, will still represent $70 \%$ of the initial plant cost. As a consequence, BOP cost reduction is most important in achieving lower total power-plant cost. The major targets for cost reduction are the heat recovery and steam generation (HRSG) unit, anode tail-gas converter, piping, controls, power-conditioning equipment, and installation. 
For a nominal 2-MW power plant, the HRSG is a single, skid-mounted, trucktransportable unit providing all of the equipment required to pre-heat and super-heat natural gas and boil water and superheat steam. Additionally, this unit contains all of the start-up and shut-down heat-exchange equipment. Multiple unit purchases, improved material use, simplification of design, and standardized manufacturing are the key elements in this cost reduction.

The anode tail-gas converter is required for carbon dioxide recycle to the cathode, preheating the cooling air for the stack, and bringing the power plant into environmental compliance with respect to emissions. All of these functions have been achieved in the ERC system with $\mathrm{NO}_{\mathrm{x}}$ and $\mathrm{SO}_{\mathrm{x}}$ levels being less than $1 \mathrm{ppm}$ in subscale but completely integrated power-plant tests at ERC and elsewhere. Cost reduction will be achieved by reducing the size of the converter through improved design.

Piping cost goals will be achieved by increasing stack size, thereby reducing the number of stacks, decreasing overall plant footprint and optimizing stack packaging at the module level.

Conventional utility-grade control systems are presently being used and are offthe-shelf hardware items. Larger size power plants benefit from lower control costs per kilowatt.

The final major cost item is the inverter and related electrical equipment required to connect the inverter to the power grid. The inverter efficiency increases and the per kilowatt cost decreases as the power-plant size increases. Much of the required inverter technology is available from motor-adjustable speed drives. However, power quality and voltage variations from site to site present a challenge to arriving at a standard design. In addition, standards need to be reevaluated to reduce the cost of connections to the grid as considerable cost savings can be achieved by simplifying the protective equipment currently required for making grid connections. Cost reduction is desirable and can be achieved by 
relatively modest redesigns of existing equipment and by increasing production to 100 units per year.

Installation is a hidden but very real cost. Site preparation and equipment must be standardized. This is a very difficult task since different sites may be very different and such items as water and gas quality and pressure, soil properties, permitting requirements, local labor capabilities, weather, and natural disaster situations vary greatly across North America. As in many other manufacturing areas, the costs per kilowatt decrease with increasing plant size for obvious reasons. For stationary MCFCs, dealing effectively with installation-related costs is an important element in fuel-cell plant design.

\section{IX-2.7. MCFC Stack-Development Testing to 1994}

A useful overview of the 1994 status of MCFC stack testing has been prepared by J. R. Selman et al. ${ }^{27}$ The essential conclusions are summarized in Table LX-2.3, which includes also recent information obtained from ERC.

The data in Table IX-2.3 can only be used for qualitative purposes. For quantitative evaluations, it is necessary to know system conditions including fuel and oxidant utilizations, gas compositions, BOP characteristics, and other factors which strongly impact stack-performance data. Values given for current density, power density, and operating pressure probably correspond to maximum stack performance. Stack lifetimes do not neccessarily correspond to operation under these conditions and, in most cases, reflect "hot time" during a sequence of variable operating conditions. 
Table IX-2.3. MCFC-stack tests to $1994^{*}$

\begin{tabular}{|c|c|c|c|c|c|c|c|}
\hline $\begin{array}{l}\text { Developer } \\
\text { (MCFC } \\
\text { Type) }\end{array}$ & $\begin{array}{c}\text { Power } \\
\text { kW }\end{array}$ & Area, $\mathrm{m}^{2}$ & $\begin{array}{l}\text { Number } \\
\text { of Cells }\end{array}$ & $\begin{array}{l}\text { Current } \\
\text { Density, } \\
\mathrm{mA} / \mathrm{cm}^{2}\end{array}$ & $\begin{array}{l}\text { Power } \\
\text { Density } \\
\mathrm{mW} / \mathrm{cm}^{2}\end{array}$ & $\begin{array}{c}\text { Pressure, } \\
\text { MPa }\end{array}$ & $\begin{array}{c}\text { Operation } \\
\text { Time, } \\
h \times 10^{-3}\end{array}$ \\
\hline $\begin{array}{l}\text { ERC } \\
\text { (IIR) }\end{array}$ & $\begin{array}{r}2 \\
5 \\
70 \\
120 \\
130\end{array}$ & $\begin{array}{l}0.37 \\
0.37 \\
0.37 \\
0.60 \\
0.60\end{array}$ & $\begin{array}{r}5 \\
11 \\
234 \\
246 \\
258\end{array}$ & $\begin{array}{l}160 \\
140 \\
120 \\
125 \\
140\end{array}$ & $\begin{array}{r}113 \\
105 \\
93 \\
100 \\
107\end{array}$ & $\begin{array}{l}0.1 \\
0.1 \\
0.1 \\
0.1 \\
0.1\end{array}$ & $\begin{array}{c}10 \\
5 \\
2 \\
1.8 \\
\text { New Test }\end{array}$ \\
\hline $\begin{array}{l}\text { M-C } \\
\text { Power } \\
\text { (DIR) }\end{array}$ & 25 & 1.06 & 20 & 160 & 109 & 0.1 & 2.5 \\
\hline $\begin{array}{l}\text { Hitachi } \\
\text { (IIR) }\end{array}$ & 100 & 1.2 & 88 & 150 & 109 & 0.7 & 1.7 \\
\hline $\begin{array}{c}\text { IHI } \\
\text { (IIR) }\end{array}$ & $\begin{array}{r}3 \\
100\end{array}$ & $\begin{array}{l}1.4 \\
1.0\end{array}$ & $\begin{array}{r}2 \\
102\end{array}$ & $\begin{array}{l}175 \\
150\end{array}$ & $\begin{array}{l}121 \\
126\end{array}$ & $\begin{array}{l}0.1 \\
0.7\end{array}$ & $\begin{array}{l}2.1 \\
5.1\end{array}$ \\
\hline $\begin{array}{l}\text { MELCO } \\
\text { (DIR) }\end{array}$ & 30 & 0.5 & 62 & 150 & 106 & 0.1 & $\begin{array}{l}\geq 8.5 \\
\text { (operating) }\end{array}$ \\
\hline $\begin{array}{l}\text { MELCO } \\
\text { (IIR) }\end{array}$ & 100 & 0.5 & 192 & 150 & 114 & 0.1 & 2.3 \\
\hline $\begin{array}{l}\text { ECN } \\
\text { (DIR) }\end{array}$ & $\begin{array}{r}1 \\
10\end{array}$ & $\begin{array}{l}0.1 \\
0.335\end{array}$ & $\begin{array}{l}10 \\
33\end{array}$ & $\begin{array}{l}150 \\
150\end{array}$ & $\begin{array}{l}109 \\
125\end{array}$ & $\begin{array}{l}0.1 \\
0.4\end{array}$ & $\begin{array}{l}0.7 \\
2.1\end{array}$ \\
\hline
\end{tabular}

${ }^{*}$ Stack tests completed before 1990 (e.g., at IFC) are not included in this table. 


\section{IX-3. Research to Make Better and Cheaper SOFC Systems}

Because of the greatly different commercialization status and schedules for tubular and planar SOFCs, the preferred product-improvement agendas for these FC systems have both important commonalities and differences.

\section{IX-3.1. Introduction}

Discussions of the progress of SOFC systems toward commercialization and comparisons with other FC systems have been presented in Chapters I, II and especially in Chapter $\mathrm{V}$ from the manufacturers' perspectives. This section deals with identification and discussion of technological issues that presently hinder realization of the full potential of SOFC systems. The size and general character of an SOFC system is dictated to a considerable extent by the intended application.

Although different markets may be envisioned (compare Chapter IV), three especially important areas for application have been identified: (a) central station electrical power generation (about $300 \mathrm{MW}$ or more), (b) distributed electrical power generation stations connected to the grid ( 2-10 MW), and (c) dispersed power and heat generators not connected to the grid (2-100 MW). In each case, the preferred fuels are likely to be NG or coal-derived gas. Other technologies also compete in these markets. For SOFC systems or any other FC system to succeed in a utility market, it must offer advantages in terms of (a) lower cost of electricity, which includes as important components the conversion of fuel to useful energy (heat rate, Btu/kWh) and the initial installed cost $(\$ / \mathrm{kW})$, (b) availability and reliability, and (c) meeting or exceeding applicable emission standards. Strong competitors are combined-cycle gas turbines (CCGTs), which have heat rates in advanced designs that are about the same as those of 
SOFC systems* and which currently have much lower installed costs because they represent a more mature technology. The ultimately projected costs of electricity from SOFC and CCGT systems, based on preliminary estimates, are comparable. Therefore, the critical challenge in the commercialization of SOFC systems is reduction of system costs, including reduced stack costs, and verification of system reliability and superior performance through the operation of demonstration units.

Of the four FC systems dealt with in this evaluation, the SOFCs operate at the highest temperatures, which afford significant potential system-performance advantages. The high temperatures also impose significant constraints on choices of construction materials, both for the cell stack and balance of plant. These well recognized advantages are summarized in Table IX-3.1.

Table IX-3.1. Advantages of SOFC systems over other FC systems.

\begin{tabular}{c|l}
\hline Operational Characteristics & \multicolumn{1}{c}{ Advantages } \\
\hline High-temperature operation & $\begin{array}{l}\text { Allows direct use of hydrocarbon fuels without a } \\
\text { separate reformer. } \\
\text { The exhaust gas from the stack is a useful energy } \\
\text { commodity, either as process heat or as input to a } \\
\text { bottoming cycle for generating electricity. }\end{array}$ \\
\hline $\begin{array}{c}\text { High power density, } \\
\text { especially for planar designs }\end{array}$ & $\begin{array}{l}\text { Reduces materials cost per unit power output. } \\
\text { Reduces the required footprint for the module. }\end{array}$ \\
\hline Use of ceramic cell materials & $\begin{array}{l}\text { Materials are inherently stable in their local } \\
\text { environments. } \\
\text { Low inter-diffusion rates mean low corrosion rates and } \\
\text { long life. } \\
\text { There is no need to control corrosive liquid electrolytes. }\end{array}$ \\
\hline Fuel flexibility & $\begin{array}{l}\text { SOFC systems may be operated with different fuels } \\
\text { without extensive fuel processing or modification of the } \\
\text { cell design. }\end{array}$ \\
\hline
\end{tabular}

The development of SOFC systems in the U.S. has been following two separate pathways for stack designs. Tubular cell designs have been used by Westinghouse whereas other designs by many developers are planar or monolithic. Why are there two

\footnotetext{
* An SOFC operating on NG at atmospheric pressure and $1000 \mathrm{C}$ has a maximum theoretical efficiency approaching $62 \%$ and a practical efficiency of $50 \%$ under economical operating conditions. With exhaust heat recovery via a steam cycle, the efficiency could reach $65 \%$. Pressurized systems with a combined cycle could attain $70 \%$
} 
basically different designs? Certainly part of the reason is historical in that the fuel cell was an application derived from studies of $\mathrm{ZrO}_{2} \cdot \mathrm{Y}_{2} \mathrm{O}_{3}$ as an oxygen sensor, which was often a closed-end tube. More importantly, the processing for the tubular design fuel cell, which follows conventional ceramic techniques, is relatively easy. The tubes are made individually and then assembled into a bundle with a very compliant mechanical connection joining the tubes. On the other hand, forming a planar stack generally involves a sequence of layers in intimate (mechanical) contact, which mean that stresses will arise at the interfaces between components and between cells owing to differences in thermal expansions. Additionally, some of the layers have gas channels which will lead to stress concentrations at corners and other geometrical discontinuities. All in all, the ceramic processing of planar stacks represents a very significant challenge. The benefits to be derived from the planar designs are potentially higher power densities and lower IR losses. The latter benefits derive from shorter path lengths for the conduction of electrons through the stack for planar as compared to the presently manufactured tubular design cells. ${ }^{29}$ The actual IR losses for either planar or tubular designs depend on details of the cell geometries.

Although the tubular and planar SOFC-stack designs have many common elements (with few exceptions, the materials used for the anodes, cathodes, electrolyte, and interconnects are similar), some features other than cell and stack geometries are significantly different. Two important differences are operating temperatures and seals. Some of the developers of planar designs are seeking to operate at temperatures of 600$850 \mathrm{C}$ to allow the use of metallic interconnects, which relax some constraints on cell construction, reduce internal electrical resistance and also reduce the costs of materials in the balance of plant. Westinghouse, on the other hand, continues to operate its tubular

${ }^{29}$ U. G. Bossel, "Performance Potentials of Solid Oxide Fuel Cell Configurations." EPRI Report TR10119, Electric Power Research Institute, Palo Alto, CA (1992). 
designs successfully at $1000 \mathrm{C}$ and is considering even higher temperatures (1050-1100 C) for large, central-station, integrated power plants. The tubular design does not require a seal to separate the anode and cathode chambers at the fuel and oxidant inlets; also used is a porous and mechanically compliant support board at the electrode outlets, which allows the remaining fuel and oxidant to mix and burn. The planar or monolithic designs require gas-tight seals as part of the manifolding scheme to separate fuel and oxidant. This seal remains an important technological development issue.

As has been repeatedly stated throughout this report, the tubular design of Westinghouse is significantly closer to commercialization than any of the alternative planar or monolithic designs. Because of their different states of maturity, the research needs for planar and tubular cell designs also differ. We list in Table IX-3.2, in no particular order of importance, research issues and their relevance to the two categories of cell geometry. At the present time, lower cost manufacturing strategies are of high priority for the tubular cells, whereas improved materials and stack-fabrication processes are of prime near-term importance for the planar and monolithic cells. 
Table IX-3.2. SOFC research issues and their importance (noted by an X) for planar (or monolithic) and tubular cells.

\begin{tabular}{l|c|c}
\hline \multicolumn{1}{c|}{ Research Program } & $\begin{array}{c}\text { Planar or } \\
\text { Monolithic } \\
\text { Cells }\end{array}$ & $\begin{array}{c}\text { Tubular } \\
\text { Cells }\end{array}$ \\
\hline $\begin{array}{l}\text { Improved anode to lower polarization } \\
\text { Improved cathode to lower polarization }\end{array}$ & $\mathrm{X}$ & $\mathrm{X}$ \\
\hline $\begin{array}{l}\text { Improved electrolyte for low temperatures } \\
\text { metallic materials (for low cell temperatures) }\end{array}$ & $\mathrm{X}$ & $\mathrm{X}$ \\
\hline $\begin{array}{l}\text { Improved interconnects made of } \\
\text { Improved seals }\end{array}$ & $\mathrm{X}$ & \\
\hline $\begin{array}{l}\text { Improved manufacturing and fabrication processes for } \\
\text { stack components }\end{array}$ & $\mathrm{X}$ & $\mathrm{X}$ \\
\hline Lower cost manufacturing of cell and stack components & $\mathrm{X}$ & $\mathrm{X}$ \\
\hline Mechanical \& physical properties of cell components & $\mathrm{X}$ & $\mathrm{X}$ \\
\hline Contaminant (e.g., sulfur) tolerance & $\mathrm{X}$ & $\mathrm{X}$ \\
\hline Application studies & $\mathrm{X}$ & $\mathrm{X}$ \\
\hline Thermal management of the stack & $\mathrm{X}$ & $\mathrm{X}$ \\
\hline Stack-failure modes and failure propagation through stacks & $\mathrm{X}$ & $\mathrm{X}$ \\
\hline $\begin{array}{l}\text { Effects of pressurization on stack performance and } \\
\text { reliability }\end{array}$ & $\mathrm{X}$ & $\mathrm{X}$ \\
\hline
\end{tabular}

\section{IX-3.2. Tubular Cell-Design Improvements}

Westinghouse has produced and tested $25-\mathrm{kW}$ systems and is currently (1994) constructing a $100-\mathrm{kW}$ system. These system demonstrations will provide critically needed information about stack performance, control and reliability and serve to identify stack- and system-design flaws if any. Continuation of these demonstrations and construction of larger units with balance of plant are essential requirements for progress toward commercialization. As the performance, reliability and operating lifetimes of these systems are established, the need for cost reduction has become apparent. Costreduction opportunities must be sought in cell- and stack-manufacturing processes, in component improvements and in stack integration with the balance of plant. In its continuing development program, Westinghouse has increased the cell length to $1.5 \mathrm{~m}$ and has significantly improved the manufacturing processes. Two-meter long cells are being planned for the near term. 
The following research and development issues have been identified for the tubular SOFC design:

(i) Development and characterization of interconnect materials with improved stability with respect to the range of oxygen activity encountered while retaining the present electrical conductivity or improving it (the present interconnect is $\mathrm{Mg}$-doped $\mathrm{LaCrO}_{3}$ ). Issues include microstructural, chemical and dimensional stability, diffusion rates of oxygen and hydrogen, and improved manufacturing processes.

(ii) Development of air electrode materials with improved pore-structure stability and lower polarization (the present air electrode is Sr-doped $\mathrm{LaMnO}_{3}$ ). Issues include phase equilibria over a range of temperatures and oxygen pressures, effects of dopants on dimensional stability, sintering, thermal expansion and creep, and factors influencing the effectiveness of the air-electrode interface including interdiffusion.

(iii) Identification of lower cost alternative fabrication processes for electrolyte and fuel electrode cell components. The present electrolyte is $\mathrm{ZrO}_{2} \cdot \mathrm{Y}_{2} \mathrm{O}_{3}$ applied by electrochemical vapor deposition. The fuel electrode is Ni-YSZ cermet applied by using slurry coat electrochemical vapor deposition.

(iv) Determination of physical and mechanical properties of cell and stack components as a function of temperature to aid in the design and modeling of stack performance and lifetime.

(v) Development of contaminant- (especially sulfur-) tolerant fuel electrodes.

(vi) Investigation of the effect of pressurized operation on performance and lifetime of stack components.

(vii) Development of low-cost, high-performance, castable insulation materials.

(viii) Development of high power density tubular designs. 


\section{IX-3.3. Planar Cell-Design Improvements}

Planar SOFCs may be characterized as flat-plate or monolithic designs. In the monolithic design, the active cell components (anode-electrolyte-cathode) are configured in a compact corrugated structure. The flat-plate designs typically have the active cell components as plates, with corrugations in other components such as the interconnect serving as fuel and oxidant channels. Gas-flow configurations may be of either the crossflow or co-flow types; the former have been favored because of simpler gas manifolding. Planar SOFCs have several potential advantages over other FC systems: multiple fabrication options leading to lower manufacturing costs, higher power densities leading to lower materials costs, and improved energy-conversion performance. They also offer the potential for considerable flexibility in the designs of stacks. However, significant additional research and development will be needed to realize these advantages in competitive commercial products.

Several vendors are exploring alternative cell materials and cell designs that will operate at lower temperatures with the same or better performance as at $1000 \mathrm{C}$. Operational goals are in the range of $600-850 \mathrm{C}$ for which intra-cell reforming of $\mathrm{HC}$ fuels would be expected to proceed efficiently. Reduced cell temperatures offer the following advantages: (i) use of metallic interconnnects, (ii) relaxation of some constraints on materials choices for the BOP, (iii) reduction in the severity of requirements on the performance of sealants, (iv) reduction of thermal stresses, and (v) potentially longer life and greater reliability. However, reduced temperatures also decrease the conductivities of ceramic components which impacts performance. In present cells, the lowest conductivity component is typically the electrolyte. The attendant higher IR polarization at reduced temperatures must be overcome with improved materials, i.e. by using a different electrolyte material or thinner cell 
components or both. At the present time, an acceptable alternative electrolyte has not been identified.

As has been previously stated, the planar technology is significantly less mature than the tubular design, especially in terms of practical stack demonstrations and systemapplication studies. Flat-plate stacks with cell areas (footprints) of about $225 \mathrm{~cm}^{2}$ and containing 200 cells have been fabricated. Long-term operation (thousands of hours) has also been demonstrated for flat-plate multi-cell stacks. Prototype stacks of 1-kW size have been built and tested by two vendors (Ceramatec and Ztek). Research needs for these developers are primarily in the categories of materials development, especially sealants, improved fabrication technologies, and proof-of-concept demonstrations. Materials and methods of fabrication are necessarily strongly coupled.

The following areas have been identified as requiring additional research and development efforts for planar SOFC designs:

(i) Scale-up in terms of cell size and the number of cells in a multi-cell stack. Issues include demonstrations of lifetimes and operating envelopes and development of improved designs for higher power densities.

(ii) Fuel-electrode polarization should be reduced by introducing improved materials and fabrication techniques. As one example, a $\mathrm{CeO}_{2}$ fuel electrode, which exhibits both electronic and oxygen-ion conductivities, has been suggested but its performance remains unproved in stack tests.

(iii) Yttria-stabilized zirconia (YSZ) is a superb electrolyte in most respects, especially because it has low electronic conductivity over a wide range of temperatures and oxygen activities. However, its relatively low ionic conductivity is often the major source of IR loss in an SOFC stack and, at reduced temperatures, this problem may become of crucial importance. To overcome this difficulty, two approaches have been suggested, viz., make the electrolyte very thin but without allowing gas leaks or switch to another 
electrolyte material. Doped $\mathrm{Bi}_{2} \mathrm{O}_{3}$ and doped $\mathrm{CeO}_{2}$ have been explored, but both materials presently suffer from unacceptable electronic conductivity at the lower oxygen partial pressures associated with the fuel. Near-term emphasis on developing fabrication technologies to produce ultra-thin, defect-free YSZ electrolytes may produce useful incremental benefits. Over the long term, basic studies of solid electrolyte materials may allow developers to leapfrog this issue through discovery of a new electrolyte.

(iv) The interconnect material must exhibit high electrical conductivity in both fuel and air, and it must be gas-tight. The present ceramic material (doped lanthanum chromite) is difficult to densify during cell fabrication while it is in contact with other components. This approach requires a compatible sintering strategy to avoid damage to pre-existing components. The large range of oxygen pressures and constraints relating to the CTE impose severe demands on the materials. Further materials developments are required to reach cost-effective solutions. For a stack intended to operate at lower temperatures, a metallic interconnect must combine oxidation resistance sufficient to survive the desired stack life, high electrical conductivity (including the protective scale) over the lifetime, and compatible CTE. Given these constraints, the choice of alloy for a metallic interconnect is not trivial. The authors of a recent Japanese paper ${ }^{30}$ reported some success with a slurry coating on a conventional Ni-base alloy, but there still remain unresolved problems with use of this candidate material.

(v) Planar SOFCs require some sort of a gas-tight seal, the location of which depends on the particular design. This seal component must be compatible with the stackfabrication technique and, over the long term, with the cell components, both with respect to chemistry and for accommodation of any strains arising during thermal cycling. Both crystalline and glassy oxide phases have been considered. For example, silicate base

30 T. S. Kadowaki, E. Matsuda, H. Nakagawa, and H. Tsunmeizumi, "Applicability of Heat Resisting Alloys to the Separator of Planar Type Solid Oxide Fuel Cells," Solid State Ionics 67, 65-69 (1993). 
glasses can be formulated with an appropriate viscosity and CTE, but the surface migration of $\mathrm{Si}$ appears to compromise the electrolyte seriously. There remain unresolved problems with the present candidate materials.

(vi) The planar or monolithic cell stack, perhaps more than the tubular stack, is a contiguous structure of dissimilar ceramics, and therefore the structure appears to be relatively more prone to experience strains on thermal cycling. When these strains or stresses become sufficiently great, the weakest component of the structure will crack. There is a need for mechanical property data for all stack components, particularly measurements of fracture toughness, that will allow prediction of possible mechanical failure during the design stage and observation of failures during testing to achieve better understanding. Such materials property measurements need to be made as a function of temperature and in the appropriate environment for fuel-cell applications because the mechanical properties may be structure-sensitive and interface-sensitive and may therefore vary with fabrication technology. New data on mechanical materials properties will benefit all cell designers since little information is now available. This information is generally needed to carry out analyses of stresses and failure mechanisms as an aid to determining the application ranges of stack designs and system-process conditions.

(vii) The thermal management of stacks, typically by control of the air flow, is a strong function of the geometry of the stack design and operating conditions. Sophisticated modeling of heat flows is needed to understand temperature distributions throughout the stacks, which affect local cell and total stack performance. The authors ${ }^{31}$ of one such study recently demonstrated that thermal radiation, which is not usually considered, is a very important component of heat flow in SOFC stacks. The thermal-management and stack-performance models require as inputs physical property data such as thermal

31 J. Hartvigsen, S. Elangovan and A. Khandkar, "Modeling, Design and Performance of SOFCs," Symp. on Sci. and Tech. of Zirconia, Amsterdam, The Netherlands (1992). 
conductivities and emissivities, which are not well established for many potential cell materials.

(viii) Development of contaminant-(especially sulfur-) tolerant materials for the anode.

\section{IX-3.4. Commonalties in Tubular and Planar SOFC Requirements}

There are several areas of research that will benefit the designs and operations of both tubular and planar cell types:

(i) Developments of ceramic interconnect materials with improved materials properties such as stability and conductivity over a range of oxygen partial pressures and more desirable sintering properties for processing and manufacturing of cell components, (ii) Development of an interpretive framework for the mechanical (fracture) properties of thin, multi-layer ceramic films and measurements of the basic properties of materials such as fracture toughness, which will ultimately allow predictions of failures for specified geometries.

(iii) Development of contaminant-tolerant fuel electrodes.

(iv) Development of lower cost, reliable manufacturing techniques for all types of SOFC stacks.

(v) Development of non-destructive evaluation (NDE) techniques to detect flaws in cell components during manufacturing processing and fabrication, e.g., detect pin holes of critical sizes and microcracks in ultra-thin electrolyte layers.

(vi) Development of a coherent total analysis of failure modes to support the NDE analyses. 


\section{IX-4. Supporting Research to Make Better and Cheaper PEMFCs}

\section{IX-4.1. Introduction}

While PEMFC-system development is ultimately aimed to include transportation applications, it is generally agreed that reaching this goal will be facilitated by concurrent or prior commercialization of stationary power-plant applications. The primary reason for this statement is the very drastic cost reduction that must be achieved for any operating power plant that replaces the internal combustion engine. Fortunately, there is a large and well defined niche market in the stationary arena for low-temperature PEMFCs, which will be utilized during the period 1996 to about 2005 to perfect commercial designs, reduce costs, increase operating life, and develop special FC-system features needed for transportation applications.

\section{IX-4.2. Description of the PEMFC.}

A schematic of an $\mathrm{H}_{2} / \mathrm{O}_{2}$ PEMFC is shown in Fig. IX-4.2.1. This FC has some similarities to the PAFC. Its electrodes are of the gas-diffusion type with $\mathrm{Pt}$ catalyst supported on carbon. The electrolyte is a thin polymer film which permits selective conduction of protons. In general, these cells operate at pressures of one to several bar and temperatures below $100 \mathrm{C}$. The temperature of operation is limited because currently available proton-conducting polymers require water for reasonable conductivity.

Significant features of the PEMFC are summarized in Table IX-4.2.1. The PEMFC is simple in design and operation. Although low-temperature operation offers some significant advantages compared with higher temperature FCs, low temperatures decrease tolerance to $\mathrm{CO}$ and lead to a thermal mismatch between reformer and stack.

Because of operation at low temperatures and the absence of hazardous materials, as well as simplicity of design, developments of PEMFCs are ultimately aimed at transportation applications. A listing of DOE performance and cost goals for transportation 


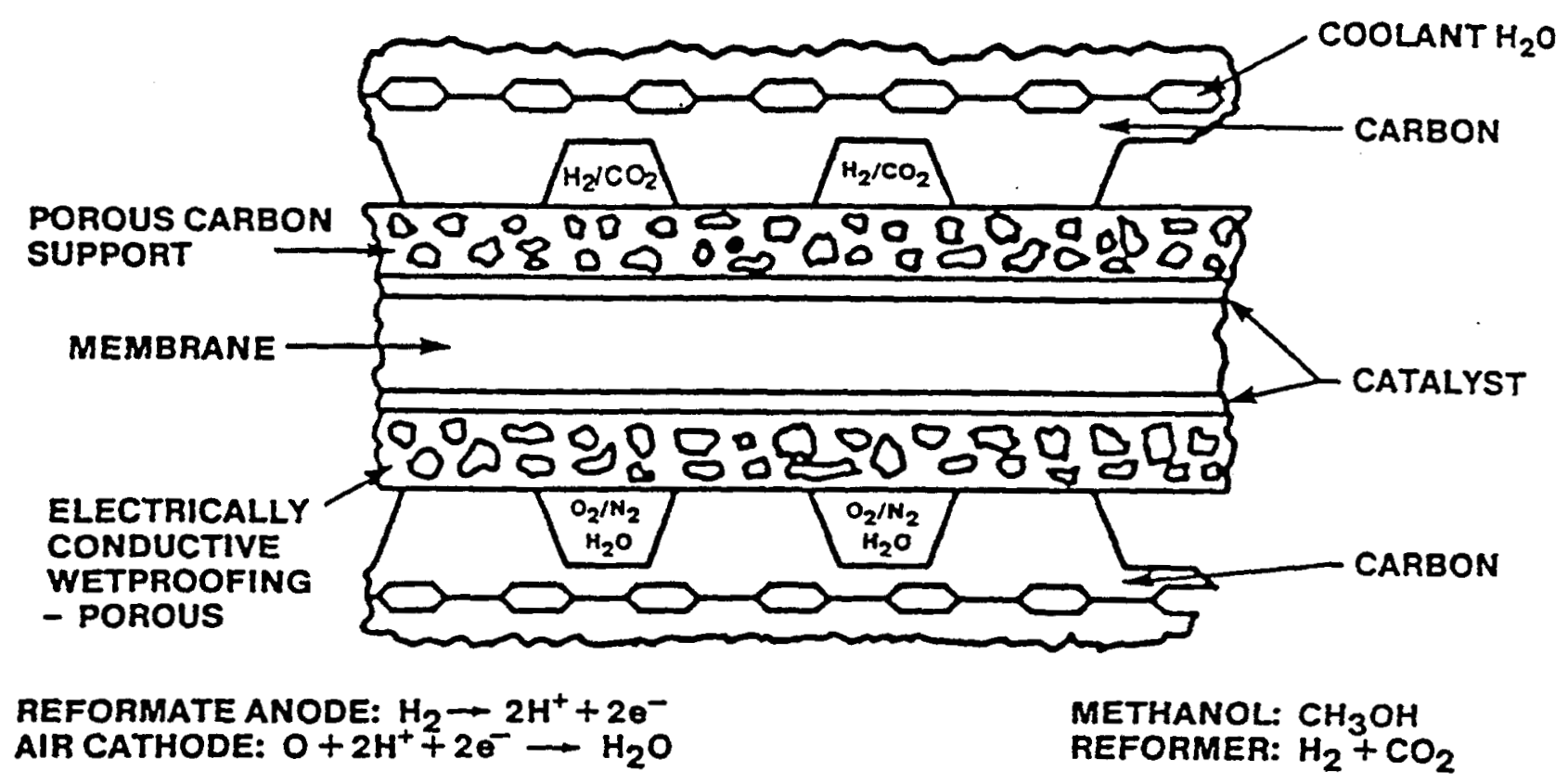

Fig. IX-4.2.1. Schematic of an $\mathrm{H}_{2} / \mathrm{O}_{2}$ reformate PEMFC.

Table IX-4.2.1. Characteristics and possible advantages of PEMFCs over hightemperature FCs.

\begin{tabular}{l|l}
\hline \multicolumn{1}{c|}{ Characteristics } & \multicolumn{1}{c}{ Possible Advantages } \\
\hline Low-temperature operation & $\begin{array}{l}\text { Lower cost and longer life. } \\
\text { For materials such as seals, there is reduced corrosion. } \\
\text { Facilitates rapid cold start-up. } \\
\text { Facilitates rapid and simplified shut-down. }\end{array}$ \\
\hline $\begin{array}{l}\text { High voltage at high power } \\
\text { density }\end{array}$ & Lower unit cost and raised FC efficiency. \\
\hline Solid electrolyte & $\begin{array}{l}\text { Is non-corrosive and no electrolyte redistribution or } \\
\text { replenishment is needed; the thin cell gap lends itself to the } \\
\text { construction of a unitized high-voltage stack configuration. } \\
\text { The ceil is pressure-tolerant and control is therefore } \\
\text { simplified. }\end{array}$ \\
\hline
\end{tabular}

applications is given in Table IX-4.2.2. Because of the difficulty of reforming at low operating temperatures, the preferred fuel for PEMFCs is $\mathrm{H}_{2}$, which may be stored or produced in an auxiliary reformer. 
Table IX-4.2.2. DOE PEMFC system-performance and cost goals for transportation applications.

\begin{tabular}{l|l}
\hline \multicolumn{1}{c|}{ FC Component } & Performance or Cost \\
\hline Weight & $4-5 \mathrm{~kg} / \mathrm{kW}$ \\
Volume & $3-5 \mathrm{l} / \mathrm{kW}$ \\
Cost & $\$ 30-40 \mathrm{~kW}$ at $10^{6} \mathrm{units} / \mathrm{yr}$ \\
Electrical conversion & $48-60 \%$ based on $\mathrm{H}_{2}$ \\
Cyclability & $300-2,000$ times $/ \mathrm{yr}$ \\
\hline Start-up time & $2-10 \mathrm{sec}$ \\
\hline
\end{tabular}

The obvious advantages of operating directly on a liquid fuel such as methanol have stimulated development efforts to reform methanol with steam at low temperatures.

Advances in improving the performance of PEMFCs have been rapid over the past several years. Numerous polarization curves have appeared in the literature. Some perspective on the extent of improvements may be gained from Fig. IX-4.2.2 for an $\mathrm{H}_{2}$ /air cell and from Fig. IX-4.2.3 for a methanol-based FC. It should be noted that methanol is a candidate fuel for mobile and transportation applications. Consequently, development efforts have been directed at both reformate feed and direct methanol feed for PEMFCs. An example of some outstanding performance results with $\mathrm{H}_{2}$ as fuel is shown in Fig. IX4.2.4. The data in Fig. IX-4.2.4 translate to a power density of $0.56 \mathrm{~W} / \mathrm{cm}^{2}$ at $1 \mathrm{~A} / \mathrm{cm}^{2}$. Single-cell, direct-methanol PEMFC performance of $260 \mathrm{~W} / \mathrm{cm}^{2}$ has been achieved at 800 $\mathrm{MA} / \mathrm{cm}^{2}{ }^{*}$ Limited but encouraging results were also obtained with 4 - and 5-cell stacks and during several hundred hours of life testing.

There are numerous technical challenges to be met in commercializing PEMFCs for stationary and transportation applications. A listing of technical challenges perceived by DOE is given in Table IX-4.2.3. The listed challenges are related to performance, application match, and cost.

\footnotetext{
* ARPA Direct Mechanol Fuel Cell Program, 9/94.
} 


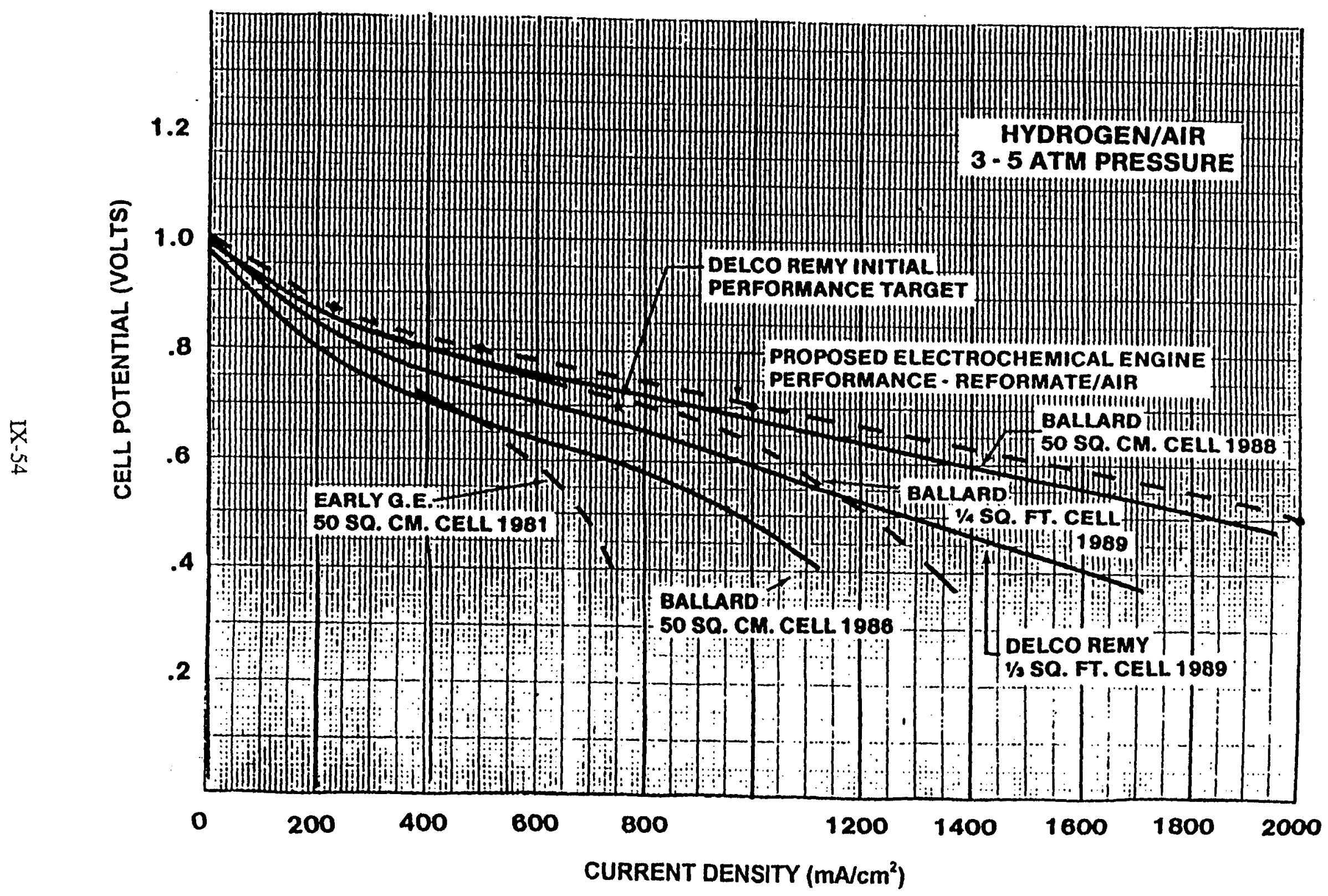

Fig. IX-4.2.2. Cell voltage vs current density for PEMFCs operating with $\mathrm{H}_{2}$ as fuel and air as oxidizer from 1981 to 1989 at 3-5 atm total pressure. 


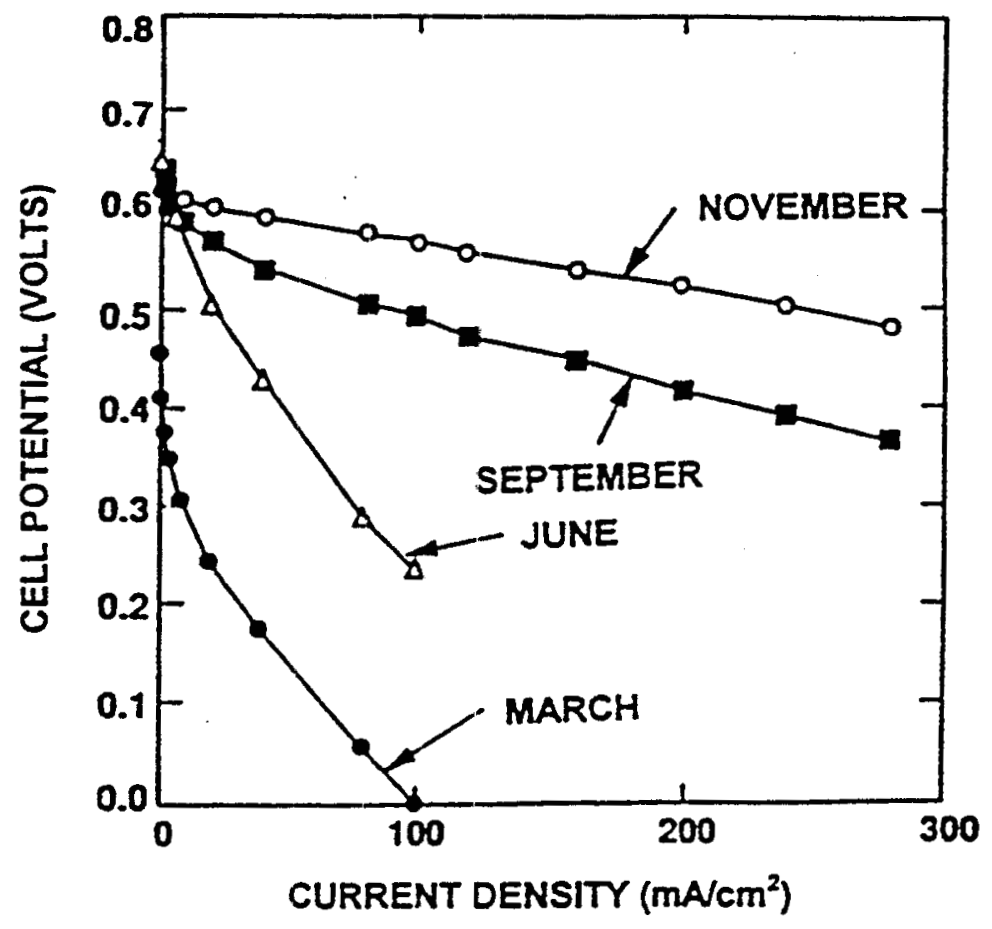

Fig. IX-4.2.3. Improvements achieved during 1992 at JPL in operating a PEMFC on direct-methanol-air. The direct-methanol PEMFC is being developed for mobile power and transporation applications.

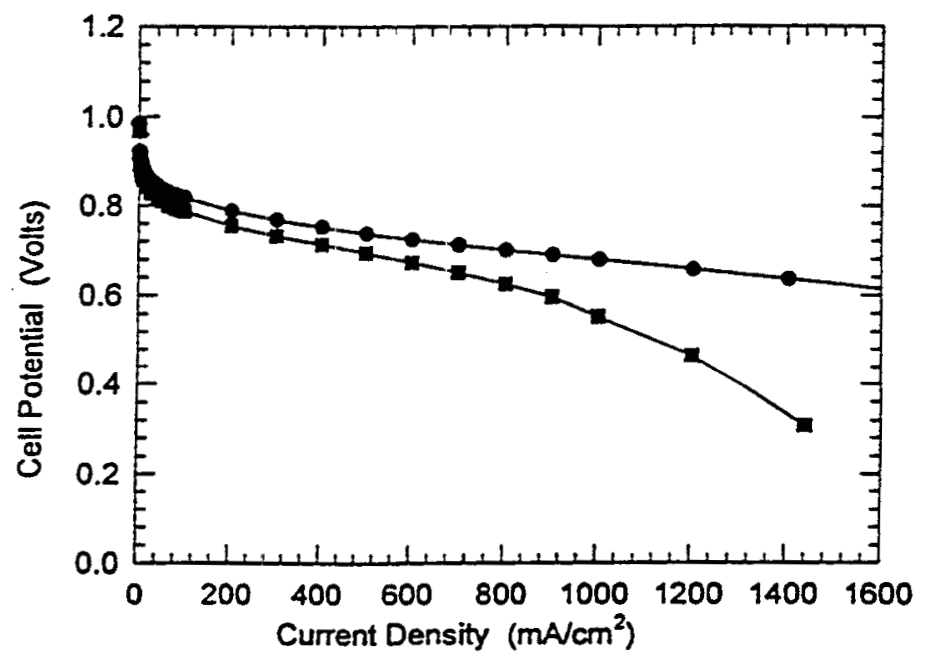

Fig. IX-4.2.4. Cell potential vs current-density plots for a single cell with a 0.05 $\mathrm{mgPt} / \mathrm{cm}^{2}$ gas-diffusion electrode at $70 \mathrm{C}$ and atmospheric pressure for a PEMFC with a Dow membrane. Either air $(\mu)$ or $\mathrm{O}_{2}(\mathrm{n})$ was used as oxidizer, $\mathrm{H}_{2}$ was the fuel. 32

32 S. Srinivasan and A.J. Appleby, Proceedings of a Symposium on "Electrode Materials and Processes for Energy Conversiional Storage III," 185th Electrochemical Society Meeting, (1994). 
Table IX-4.2.3. PEMFC-system components and technical challenges identified by DOE.

\section{The Fuel Processor}

must be compact;

have quick start and transient response; have low cost and be rugged in design; should produce low $\mathrm{CO}$ concentrations during transients.

\section{For the Power-Plant System}

volume and weight should be reduced;

thermal and functional components should be integrated;

efficient control modes and sensors should be designed;

rapid systems start-up and response to transients should be obtained;

low-temperature survivability is needed.

\section{For the Propulsion System}

components need to be optimized for application;

the drivetrain, control modes and electronics need to be optimized;

the vehicle propulsion-system interfaces should be properly integrated into the system. improved power densities when operating on reformate with air at low pressure;

improved heat and mass (gas \& water) transport over present designs;

improved tolerance to both $\mathrm{CO}$ and $\mathrm{CO}_{2}$ over present designs;

reduced creep in plastic parts.

\section{IX-4.3. The Polymer Electrolyte for PEMFCs}

In the acid PEMFC, the electrolyte is a selective proton conductor. Besides maintaining ionic charge neutrality, the polymer film must keep the oxidant and fuel from crossing to the anode and cathode, respectively. Major advantages of the polymer electrolyte include the following: no electrolyte redistribution, relatively simple design and operation, and light weight.

Polymer membranes currently receiving primary attention are the duPont Nafion, Dow, Japanese Asahi, and other materials. These polymer electrolytes are 
perfluorosulfonic acid materials. The chemical structures of the duPont and Dow materials are shown in Fig. IX-4.3.1. These polymers are the result of major R\&D efforts for purposes other than FC commercialization by the two largest U.S. chemical companies with total development costs exceeding $\$ 100$ million. Both materials are currently too costly for FC applications. The teflon-like backbone structure makes the membranes very stable and they have reasonable proton conductivity.

(a) duPont Nafion (1100 EW; $m=5, x=2)$

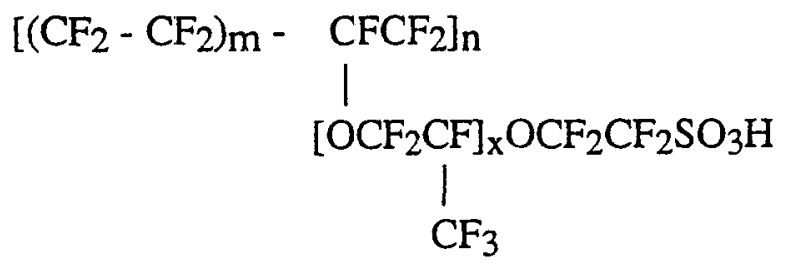

(b) Dow Polymer (800 EW; $m=10.5)$

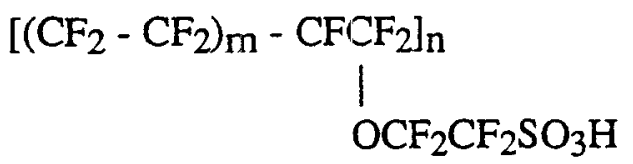

Fig. IX-4.3.1. Chemical structures of (a) the duPont Nafion and (b) the Dow polymers.

The workhorse polymer film for PEMFC R\&D has been the Nafion 117 film. This film is nominally 7 mils thick with an equivalent weight of 1100 . Its properties have been the subject of extensive studies. Noteworthy is recent work at LANL. Some of the properties of Nafion 117 are given in Table IX-4.3.1. The polymer swells by water absorption and the membrane conductivity is proportional to its water content. Consequently, operation is limited to temperatures below $100 \mathrm{C}(120 \mathrm{C}$ at several bar). To complicate matters further, movement of protons is accompanied by the drag of water molecules. As a result, water is carried from the anode to the cathode side of the membrane. This process may lead to anode drying with conductivity loss, as well as 
cathode wetting with pore blocking. The replenishment of anode water occurs through cathode-to-anode diffusion and/or water transport from the fuel gas, as is shown in Fig. IX-4.3.2. The use of very thin membranes assists the diffusion of water from the cathode

Table DX-4.3.1 Transport properties of the duPont and Dow perfluorosulfonic acid polymer films.

\begin{tabular}{|c|c|c|c|c|}
\hline \multirow[t]{2}{*}{ Property } & \multicolumn{2}{|c|}{ Nafion $117(\mathrm{EW})=1100)$} & \multicolumn{2}{|c|}{ Dow $(E W=800)$} \\
\hline & Result & Conditions/Reference & Result & Conditions/Reference \\
\hline $\begin{array}{l}\text { Conductivity, } \\
\Omega^{-1}-\mathrm{cm}^{-1}\end{array}$ & 0.065 & $\begin{array}{l}30 \mathrm{C} \text {, saturated water } \\
\text { vapor }^{2}\end{array}$ & 0.12 & $\begin{array}{l}30 \mathrm{C} \text {, saturated water } \\
\text { vapor }^{\mathrm{a}}\end{array}$ \\
\hline & 0.17 & $\begin{array}{l}80 \mathrm{C} \text {, immersed in } \\
\text { water }^{\mathrm{a}}\end{array}$ & 0.23 & $\begin{array}{l}80 \mathrm{C} \text {, immersed in } \\
\text { water }\end{array}$ \\
\hline $\begin{array}{c}\text { Water content, } \\
\mathrm{H}_{2} \mathrm{O} / \mathrm{SO}_{3}\end{array}$ & 13 & $\begin{array}{l}30 \mathrm{C} \text {, saturated water } \\
\text { vapor }^{\mathrm{a}}\end{array}$ & 14 & $\begin{array}{l}30 \mathrm{C} \text {, saturated water } \\
\text { vapor }^{\mathrm{a}}\end{array}$ \\
\hline & 20 & $\begin{array}{l}30 \mathrm{C} \text {, immersed in } \\
\text { water }{ }^{\mathrm{a}}\end{array}$ & 26 & $\begin{array}{l}30 \mathrm{C} \text {, immersed in } \\
\text { water }\end{array}$ \\
\hline . & 10 & $\begin{array}{l}80 \mathrm{C} \text {, saturated in } \\
\text { water vapor }\end{array}$ & & \\
\hline $\begin{array}{c}\text { Electroosmotic } \\
\text { drag number, } \\
\mathrm{H}_{2} \mathrm{O} / \mathrm{H}^{+} \\
\end{array}$ & 0.9 & $\begin{array}{l}30 \mathrm{C} \text {, saturated water } \\
\text { vapor }^{\mathrm{a}}\end{array}$ & 1.4 & $\begin{array}{l}30 \mathrm{C} \text {, saturated water } \\
\text { vaper }\end{array}$ \\
\hline $\begin{array}{c}\text { Hydrogen } \\
\text { permeability, barrer } \\
\text { (crossover rate in } \\
\mathrm{mA} / \mathrm{cm}^{2} \text { for } 1 \text { atm } \\
\text { differential pressure) }\end{array}$ & $\begin{array}{l}144(0.5) \\
30(0.1)\end{array}$ & $\begin{array}{l}80 \mathrm{C}, 35 \mathrm{wt} \% \mathrm{H}_{2} \mathrm{O} \text { in } \\
\text { the membrane } \\
30 \mathrm{C}, 35 \mathrm{wt} \% \mathrm{H}_{2} \text { in } \\
\text { the membrane }\end{array}$ & $\begin{array}{l}10.6 / \\
0.04 \\
\end{array}$ & $\begin{array}{l}25 \mathrm{C}, 20 \mathrm{wt} \% \mathrm{H}_{2} \mathrm{O} \text { in } \\
\text { the membrane }\end{array}$ \\
\hline $\begin{array}{l}\text { Oxygen permeability, } \\
\text { barrer } \\
\end{array}$ & 71 & $\begin{array}{l}80 \mathrm{C}, 35 \mathrm{wt} \% \mathrm{H}_{2} \mathrm{O} \text { in } \\
\text { the membraneb }\end{array}$ & $=$ & $=$ \\
\hline $\begin{array}{l}\text { Methanol crossover, } \\
\mathrm{mA} / \mathrm{cm}^{2}\end{array}$ & 250 & $\begin{array}{l}50 \mathrm{C} \text {, equimolar } \\
\text { methanol/water } \\
\text { (liquid) }^{\mathbf{d}}\end{array}$ & - & - \\
\hline
\end{tabular}

a T.A. Zawodzinski, T.E. Springer, F. Uribe, and S. Gottesfeld, Solid State Ionics 60, 199 (1993).

b T. Sakai, H. Takenaka, N. Wakabayashi, Y. Kawami, and E. Torikai, J. Electrochem. Soc. 133, 88 (1986).

c Y.-M. Tsou, M.C. Kimble and R.E. White, J. Electrochem. Soc. 139, 1913 (1992).

d S. Kato, K. Nagahama, H. Noritomi, and H. Asai, J. Membrane Sci. 72,31 (1992). 


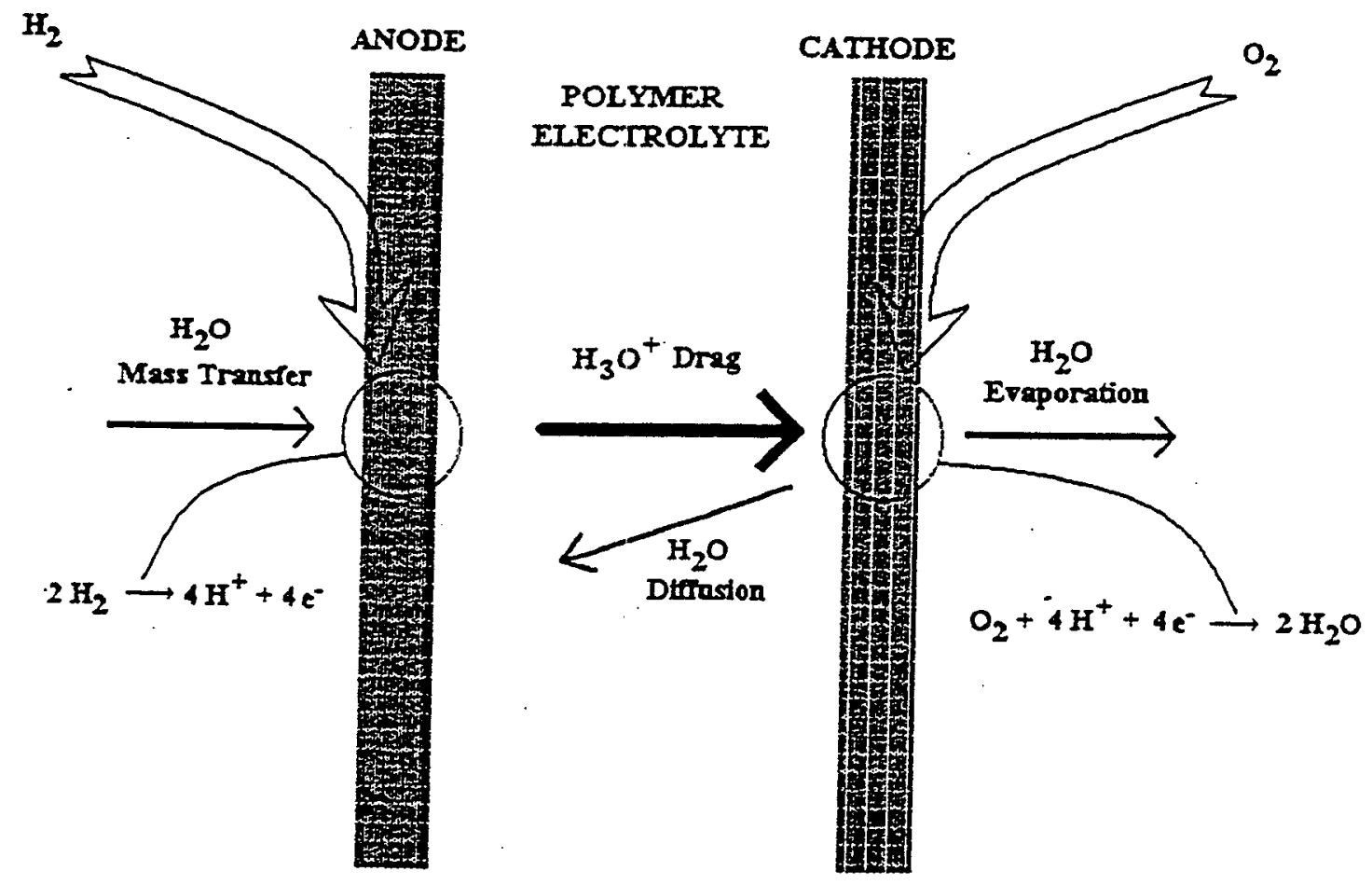

Fig. IX-4.3.2. Water transport in a PEMFC.

to the anode (US Patent 5,242,764). Maintaining a proper water balance is one of the most significant challenges in the development of PEMFCs.

The Dow 560 short-chain perfluorosulfonic acid polymer has received recent attention. The lower equivalent weight compared with Nafion 117 (560 vs 1100) provides greater water uptake. Enhanced swelling and thinner membranes ( 5 mils) result in reduced ohmic losses and also enhance the rate of water back diffusion, thus easing the watertransport issue. However, the Dow polymer is not available as a commercial product and is currently only obtainable in research quantities, which has impeded testing and FC applications.

The mechanism of proton conductivity and selectivity has been the subject of intensive investigation. A proposed structure consists of water-cluster pockets connected by pores and appears to be consistent with X-ray, conductivity, swelling, and selectivity 
data. Recently, Cahan and Wainright ${ }^{33}$ have shown Nafion to be a frequencyindependent, simple, ionic conductor.

The solubilities of gases like oxygen are considerably higher in a perfluorosulfonic acid polymer than in standard electrolytes because of the nature of the hydrophobic backbone. The larger solubility enhances oxygen-reduction kinetics. Fuel crossover is related to the permeability of the gas across the membrane. Typically for an $\mathrm{H}_{2} / \mathrm{O}_{2} \mathrm{FC}$ with Nafion, $\mathrm{H}_{2}$ crossover is $0.5 \mathrm{~mA} / \mathrm{cm}^{2}$. The fuel inefficiency and its effect on cathode performance is quite small. On the other hand, methanol fuel and especially liquid-phase methanol are highly soluble in Nafion. Thus, with $1 \mathrm{M}$ methanol in the water fuel feed, the crossover current is over $100 \mathrm{~mA} / \mathrm{cm}^{2}$ corresponding to a large fuel inefficiency. The presence of methanol at the cathode causes additional cathode polarization through the mixed potential effect. Some data that demonstrate this effect are shown in Fig. IX-4.3.3. The polarization loss of cathode potential in methanol FCs is a major problem.

A major issue with currently available membranes is cost. The Nafion polymer cost is $\sim \$ 90 / \mathrm{ft}^{2}$. It is hoped that the cost will drop by a factor of 10 if demand is increased by a factor of 100 . The lower cost polymers must retain the required stability and electrochemical properties. Development of a higher temperature polymer (150-200 C) would make the electrodes much less susceptible to $\mathrm{CO}$ poisoning. Furthermore, since water in the polymer will then become less important for proton conductivity, the waterbalance challenge will be less significant. The use of higher temperature waste heat will provide the opportunity for greater overall system efficiency.

33 JECS 140, L185 (1993). 


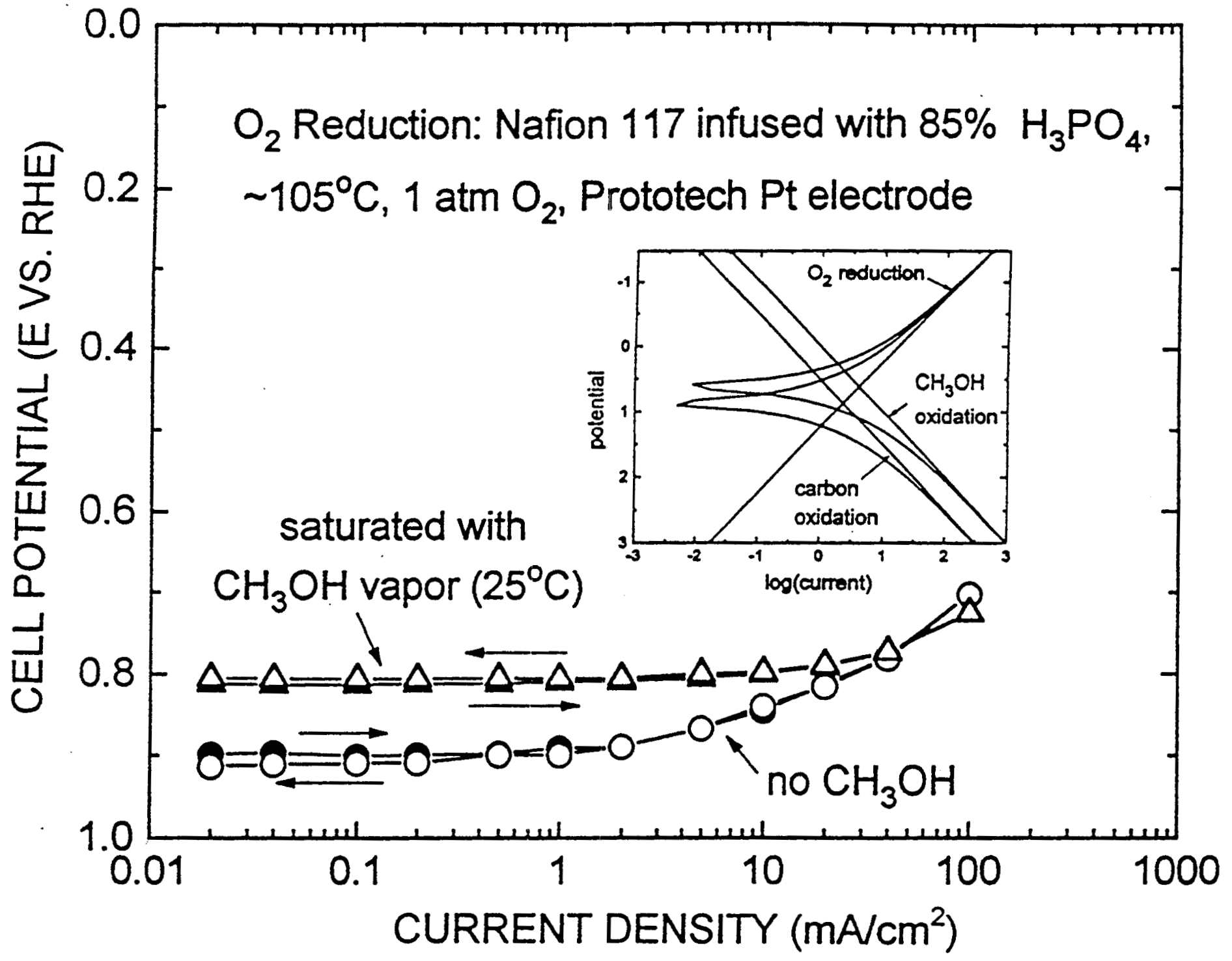

Fig. IX-4.3.3. Polarization curves for $\mathrm{O}_{2}$ reduction $\left(1 \mathrm{~atm}\right.$ of $\left.\mathrm{O}_{2}\right)$ on a Prototech Ptcatalyzed electrode ( $\mathrm{Pt}$ loading $=0.3 \mathrm{mg} / \mathrm{cm}^{2}$ ) in a micro-FC with a Nafion 117 membrane infused with $85 \% \mathrm{H}_{3} \mathrm{PO}_{4}$ at $105 \mathrm{C}( \pm 2 \mathrm{C})$ and 1 atm of $\mathrm{H}_{2}$ as the counter electrode. After first making measurements with pure $\mathrm{O}_{2}$, the $\mathrm{O}_{2}$ stream was saturated with $\mathrm{CH}_{3} \mathrm{OH}$ at $25 \mathrm{C}$. Reproduced from D.A.Tryk (Case Western Reserve University, ARPA Fuel Cell Program, July 1994). 


\section{IX-4.4. Electrode Catalyst}

Platinum has been the preferred catalyst in PEMFCs. Since these cells operate at low temperatures, it is vitally important to have highly active catalyst to reduce polarization. Early PEMFCs had Pt loadings of $2-4 \mathrm{mg} / \mathrm{cm}^{2}$. In recent years, because of a better understanding of catalyst utilization (see Sec. IX-4.5 for details), loadings have been reduced by one to two orders of magnitude.

The $\mathrm{CO}$ present in reformed $\mathrm{H}_{2}$ fuel poisons a $\mathrm{Pt}$ catalyst because of tenacious adsorption of $\mathrm{CO}$ on active $\mathrm{Pt}$ sites. A strategy for reducing $\mathrm{CO}$ poisoning is to add to the fuel a small amount of oxygen, which oxidizes the adsorbed $\mathrm{CO}$ and then removes the product $\mathrm{CO}_{2}$. Another approach is to utilize co-catalysts, e.g., $\mathrm{Sn} / \mathrm{Pt}$ or $\mathrm{Ru} / \mathrm{Pt}$ alloys or mixtures. As shown in Fig. IX-4.4.1, a Pt-Ru alloy catalyst exhibits little anode polarization loss even when operating on $25 \% \mathrm{CO}_{2}$.

With hydrocarbon fuels like methanol, catalyst poisoning is more severe. Formations of adsorbed $\mathrm{CO}$ species ( $\mathrm{CHO}$ or $\mathrm{COH}$ ) occur as intermediates. Consequently, a catalyst to activate $\mathrm{CO}$ oxidation becomes essential. Again the best catalyst found to date has been the Ru-Pt system. Some believe that $\mathrm{Pt}$ sites are necessary to activate the breaking of $\mathrm{C}-\mathrm{H}$ bonds. On the other hand, $\mathrm{Ru}$ supplies oxygen as $\mathrm{RuO}_{2}$ or $\mathrm{Ru}(\mathrm{OH})_{2}$ to oxidize $\mathrm{CO}$ on the surface. The role of Ru on catalyst performances is currently under study.

Since the oxygen-reduction reaction is inherently slow, requirements for active catalysts are especially severe on the cathode side. $\mathrm{Pt}$ is again the most active catalyst. The high activity with finely dispersed $\mathrm{Pt}$ supported on $\mathrm{C}$ is often lost with time due to $\mathrm{Pt}$ sintering. In addition, $\mathrm{Pt}$ catalyzes oxidation of the $\mathrm{C}$ substrate, thus lowering the opencircuit potential. These effects are somewhat less pronounced for PEMFCs than for PAFCs.

For direct methanol FCs, fuel crossover increases polarization at the cathode, as has been discussed in Sec. IX-4.2. To reduce this effect, active cathode catalysts are necessary 


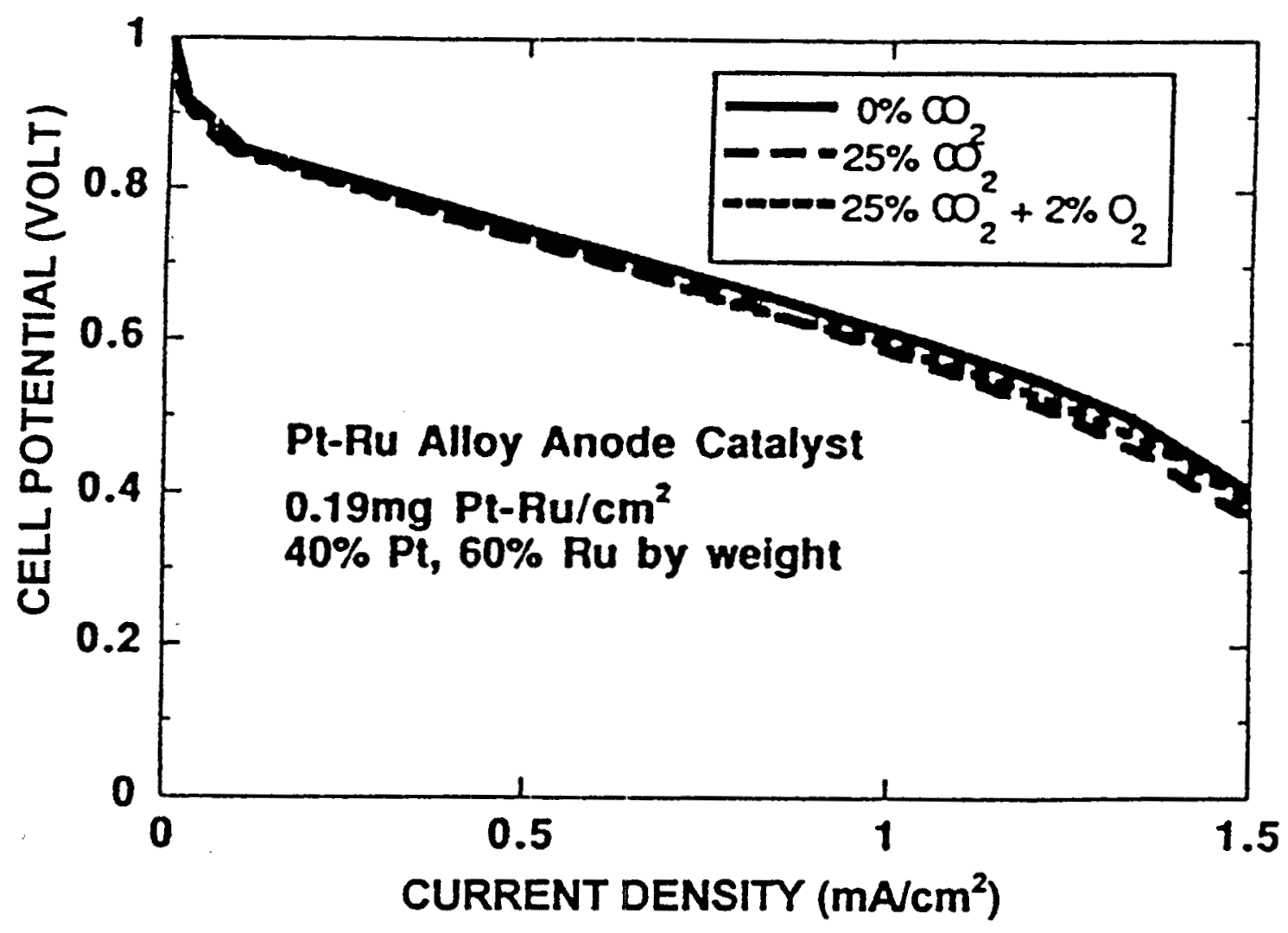

Fig. IX-4.4.1. Cell potential vs current density for various $\mathrm{CO}_{2}$ concentrations with a Pt$\mathrm{Ru}$ alloy as anode catalyst $\left(0.19 \mathrm{mg}\right.$ of $\mathrm{PtRu} / \mathrm{m}^{2}, 40 \% \mathrm{Pt}$ and $60 \% \mathrm{Ru}$ by weight). Thin-film Pt-Ru anodes show little loss of performance with 25\% $\mathrm{CO}_{2}$. This figure is reproduced from M.S. Wilson, C.R. Derouin, J.A. Valerio, and S. Gottesfeld, Proceedings of the IECEC Meeting in Atlanta, Georgia, p. 1.1203 (August 1993). 
which are tolerant of the presence of methanol. Recent investigations at Case Western Reserve University have identified a macrocycle catalyst which shows promising performance for this application (Fig. IX-4.4.2).

\section{IX-4.5. Electrode Structures}

The electrode structure brings the conducting catalyst particle into contact with the electrolyte in such a way as to minimize gas-diffusion limitations. In early versions of PEMFCs, Pt was deposited (electrolessly) into a polymer film. These electrodes had very high $\mathrm{Pt}$ loadings $\left(4 \mathrm{mg} / \mathrm{cm}^{2}\right)$. Later, it became apparent that $\mathrm{Pt}$ loadings could be decreased substantially by utilizing gas-diffusion electrodes in which carbon-supported $\mathrm{Pt}$ is blended with Teflon. Modifications were made to the standard electrode structures used in PAFCs to enhance catalyst utilization and performance. For example, the ionic conducting polymer was loaded into the electrode structure so that more catalyst would come in contact with the electrolyte. Also, the Pt films were sputtered onto the face of the electrode prior to being hot-pressed into a polymer electrolyte film. A typical structure of the standard carbonsupported electrode is shown in Fig. IX-4.5.1a. Recently, progress has been made in creating more efficient electrode structures by blending inks of carbon-supported Pt with the ionomers and then casting this product onto a polymer-electrolyte film. Such a structure is shown in Fig. IX-4.5.1b.

A goal of recent research has been the production of large membrane electrode structures with $\mathrm{Pt}$ loadings less than $0.25 \mathrm{~g} / \mathrm{kW}$ using low-cost manufacturing techniques. Work at LANL has reduced the cost of $\mathrm{Pt}$ for an $80 \mathrm{~kW}$ peak-power plant from over $\$ 30,000$ to less than $\$ 500$. 


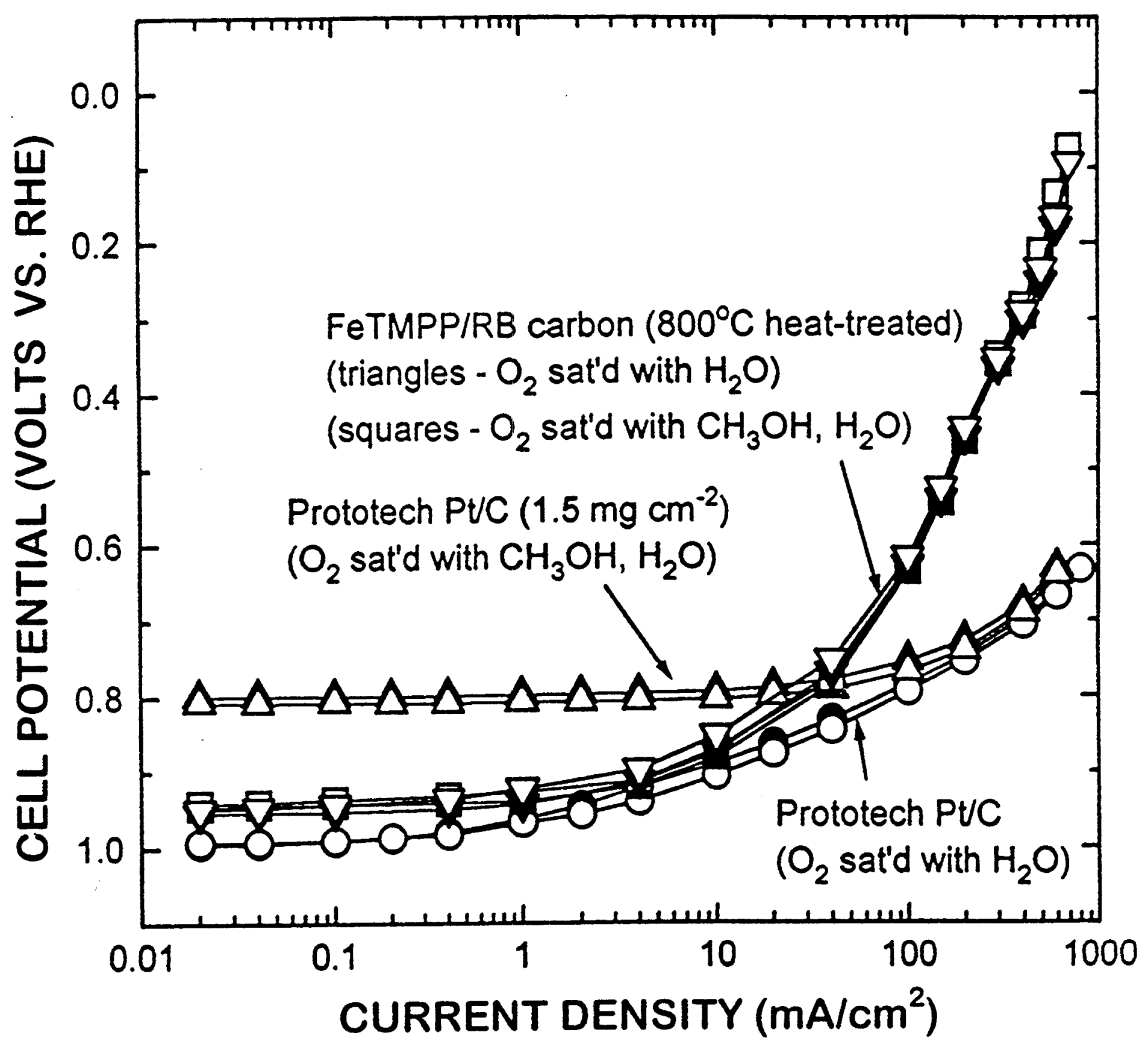

Fig. IX-4.4.2. Steady-state polarization curves for $\mathrm{O}_{2}$ reduction with porous gas-diffusion electrodes made from FeTMPP/RB carbon and Prototech Pt/C in $85 \mathrm{wt} \%$ $\mathrm{H}_{3} \mathrm{PO}_{4}$ at $\sim 100 \mathrm{C}$. Solid symbols refer to increasing current density; open symbols refer to decreasing current density. Reproduced from D. A. Tryk et al, Extended Abstracts of the Electrochemical Society, Vol. 94-1, Abstract 625 (1994). 


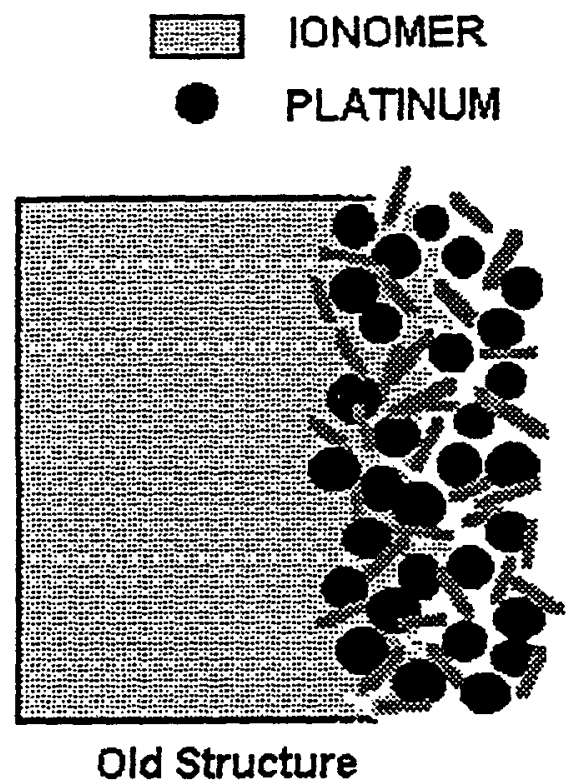

a

\section{TEFLON \\ CARBON}

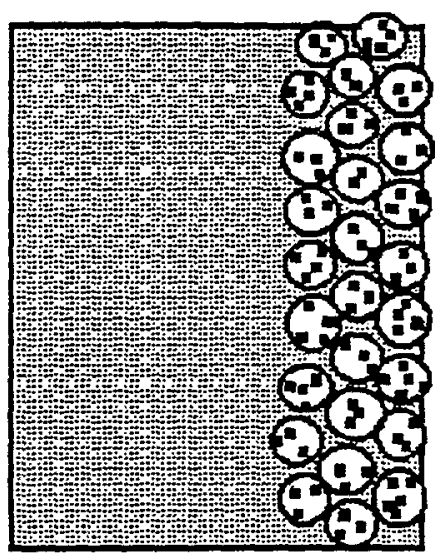

New Structure

b

Fig. IX-4.5.1. Pt/C electrode optimization. By using thin films of C-supported Pt, bound with a thermoplastic ionomer, dramatic reductions in $\mathrm{Pt}_{t}$ loadings have been achieved. This figure has been reproduced from M.S. Wilson and S. Gottesfeld, J. Appl. Electrochem. 22, 1(1992).

Further development of high performance, low-cost, reliable, and long-life electrode structures continues at a number of laboratories. Mathematical models have been developed which may be used to elucidate controlling mechanisms and will contribute to the further optimization and performance improvement of electrode structures.

\section{IX-4.6. R\&D Technology and Commercialization Needs}

Many of the development paths for commercialization of PEMFCs are the same for stationary and transportation applications. The most significant barrier to commercialization is cost. In addition, developers must prove feasibility and demonstrate 
reliability. Consequently, there is an overriding need for field demonstrations. Special concerns for transportation applications include the following: (i) on-board hydrogenstorage technologies need development; (ii) the fueling infrastructure needs development; (iii) safety concerns for vehicles with hydrogen storage must be addressed.

The research and development needs to support PEMFC development and commercialization may be categorized as short- and long-term programs. These are detailed in the following paragraphs.

\section{A. Short-Term $R \& D$ Needs for Product Improvement}

(i) Evaluation of the transport properties of commercial and available experimental ionomer membranes - A polymer with properties yielding optimum electrochemical performance must be selected. Desirable properties include high ionic proton conductivity to reduce polarization and increase current density, greater strength to permit the use of thinner membranes, optimum gas permeability to reduce fuel/air crossover without limiting electrode performance, lower electroosmotic drag to simplify operation, a stable level of hydration to simplify stack sealing, and improved stability with better tolerance to fuel and oxidant impurities.

(ii) Materials and Process Development - Improved materials and manufacturing methods need to be developed for the stack hardware. New and less expensive bipolar plate materials and flow-channel fabrication methods are needed to reduce costs. The flow-field design and manifolding need to be optimized. Current collectors must be improved and end-hardware can be simplified.

(iii) Development of lower cost and more efficient catalysts - Anodes which are tolerant to contamination and cathodes which are methanol-tolerant to fuel crossover are needed. The use of non-precious metal catalysts should reduce catalyst costs.

(iv) Electrode-structure developments - Easy to manufacture electrode structures are needed to optimize performance and maximize catalyst utilization. The structures must be reliable and long-lived. The designs of the gas-diffusion backing and of the flow field must be optimized for long-term stability, good performance with low-pressure air, and ready scale-up to large cells. Further, these designs must minimize the effects of the 
nitrogen blanket within the gas-diffusion backing that generates a diffusion barrier for oxygen access.

(v) Development of FC models - It will be necessary to predict performance over a full range of operating conditions (temperature, pressure, gas composition, load) to optimize and match designs to application requirements.

(vi) Integration and testing - It will be necessary to integrate all of the FC components into a system. Operational testing under realistic conditions will be necessary to determine changes in performance and construct reliable systems.

\section{B. Long-Term and Fundamental Research Needs}

(i) Polymer Electrolytes - A more thorough understanding of conduction and diffusion mechanisms in polymer electrolytes is needed. Models which relate structural and composition factors to transport properties should be developed. Alternative membranes which are easy to manufacture and of relatively simple chemical structure are required to reduce costs. Ionomers capable of conducting protons at somewhat higher temperatures (e.g., $200 \mathrm{C}$ ) will reduce $\mathrm{CO}$ poisoning of catalysts in FCs and increase waste-heat recovery.

(ii) Catalysts - The mechanisms of electrocatalytic oxygen reduction and fuel oxidation must be understood, including the role of the electrolyte. Reaction intermediates must be identified and limiting reaction steps must be clarified. For methanol oxidation, the roles of surface states, composition and crystalline structure of the $\mathrm{Pt} / \mathrm{Ru}$ system must be determined. Progress must continue on developing impurity-tolerant, high-performance, low-cost catalysts.

(iii) Electrode Structures - Fundamental modeling of electrodes, including microscopic and molecular approaches, are needed to understand more fully the relationship between material properties, structures and performance.

(iv) Technology Development - System components such as heat exchangers, compressors, pumps, reformers, preferential oxidizers, etc. need to be optimized in terms of material and size compatibility with the intended applications. Volumes and weights 
must be reduced by developing more compact configurations and by finding improved materials.

(v) Other Fuels - The application possibilities of PEMFCs will be greatly enlarged if efficient operation can be achieved with fuels such as methane, diesel fuel and kerosene. This goal will require breakthroughs in developing anode catalysts and reducing fuel crossover. 


\section{BIBLIOGRAPHY}

\section{Polymer Properties}

T.D. Gierke, G.E. Munn, and F.C. Wilson, "The Morphology in Nafion Perfluorinated Membrane Products, as Determined by Wide and Small-Angle X-Ray Studies," J. Polym. Sci., Polym. Phys. Ed. 19, 1687 (1981).

W.Y. Hsu and T.D. Gierke, "Elastic Theory for Ionic Clustering in Perfluorinated Ionomers," Macromolecules 15, 101 (1982).

R.S. Yeo and H.K. Yeager, "Structural and Transport Properties at Perfluorinated Ion Exchange Membranes," Modern Aspects of Electrochemistry 16, 437 (1985).

T. Sakai, H. Takenaka, N. Wakabayashi, Y. Kawami, and E. Torikai, "Gas-Diffusion in the Dried and Hydrated Nafions," J. Electrochem. Soc. 133, 88 (1986).

K.A. Mauritz, "Review and Critical Analyses of Theories of Aggregation in Ionomers," J.M.S. - Rev. Macromol. Chem. Phys. C28, 65 (1988).

Y-M. Tsou, M.C. Kimble, and R.E. White, "Hydrogen Diffusion, Solubility and WaterUptake in Dow's Short-Side-Chain Perfluorocarbon Membranes," $J$. Electrochem. Soc. 139, 1913 (1992).

S. Kato, K. Nagahama, H. Noritomi, and H. Asai "Permeation Rates of Aqueous Alcohol Solutions in Pervaporation Through Nafion Membranes," J. Membrane Sci. 72, 31 (1992).

T.A. Zawodzinski, Jr., T.E. Springer, F. Uribe, and S. Gottesfeld, "Characterization of Polymer Electrolytes for Fuel Cell Applications," Solid State Ionics 60, 199 (1993).

Methanol Fuel-Cell Catalysts

A. Aramata, T. Kodera, and M. Masuda, "Electrooxidation of Methanol on Platinum Bonded to the Solid Polymer Electrolyte, Nafion," J. Appld. Electrochem. 18, 577 (1988).

S. Gottesfeld and J. Pafford, "A New Approach to the Problem of Carbon Monoxide Poisoning in Fuel Cells Operating at Low Temperature," J. Electrochem. Soc. 135,265 (1988).

B.J. Kennedy and A.W. Smith, "Reactivity of $\mathrm{RuO}_{2}$ as a Promoter for Methanol Oxidation," J. Electroanal. Chem. 293, 103 (1990).

J.M. Leger and C. Lamy, "The Direct Oxidation of Methanol at Platinum Based Catalytic Electrodes: What is New Since Ten Years?" Ber. Bunsenges. Phys. Chem. 94, 1021 (1990). 
P.N. Ross, "Characterization of Alloy Electrocatalysts for Direct Oxidation of Methanol: New Methods," Electrochimica Acta 36, 2053 (1991).

M. Enyo, K. Machida, A. Fukuoka, and M. Ichikawa, "Investigations on the Fabrication of Active Electrocatalysts for Methanol Electrooxidation," Electrochemistry in Transition, O. Murphy ed., Plenum Press, NY (1992).

G. Meli, J.M. Leger, C. Lamy, and R. Durand, "Direct Electrooxidation of Methanol on Highly Dispersed Platinum-Based Catalyst Electrodes: Temperature Effect," J. Appld. Electrochem. 23, 1.97 (1993).

\section{Oxygen Reduction}

A.K. Shukla, P. Stevens, A. Hamnett, and J.B. Goodenough, "A Nafion - Bound Platinized Carbon Electrode for Oxygen Reduction in Solid Polymer Electrolyte Cells," J. Appld. Electrochem. 19, 383 (1989).

D.J. Manko, H. Koch, M.A. Enayetullah, A.J. Appleby, and S. Srinivasan, "Recent Advances in Solid Polymer Electrolyte Fuel Cell Technology with Low Platinum Loading Electrodes," J. Power Sources 29, 367 (1990).

A. Parthasarathy, S. Srinivasan, and A.J. Appleby, "Electrode Kinetics of Oxygen Reduction at Carbon-Supported and Unsupported Platinum Microcrystallite/Nafion Interfaces," J. Electroanal. Chem. $\underline{39}$, 101 (1992).

F.A. Uribe, T.E. Springer, and S. Gottesfeld, "A Microelectrode Study of Oxygen Reduction at the Platinum/Recast-Nafion Film Interface," J. Electrochem. Soc. 139, 765 (1992).

E. Yeager, M. Razaq, D. Gervasio, A. Razaq, and D. Tryk, "Dioxygen Reduction in Various Acid Electrolytes," J. Serb. Chem. Soc. 12, 817 (1992).

E. Yeager, M. Razaq, D. Gervasio, A. Razaq, and D. Tyrk, "The Electrolyte Factor in $\mathrm{O}_{2}$ Reduction Electrocatalysis." Proc. of Workshop on Structural Effects in Electrocatalysis and Oxygen Electrochemistry, D. Scherson, D. Tyrk, M. Daroux and X. Xing eds., Volume 92-11, The Electrochemical Society, Pennington, NJ (1992).

S. Mukerjee, S. Srinivasan, and A.J. Appleby, "Effect of Sputtered Film on Platinum on Low Platinum Loading Electrodes on Electrode Kinetics of Oxygen Reduction in Proton Exchange Membrane Fuel Cells," Electrochimica Acta 38, 1661 (1993).

Electrode Structures

A. Aramata and R. Ohnishi, "Methanol Electrooxidation on Platinum Directly Bonded to a Solid Polymer Electrolyte Membrane," J. Electroanal. Chem.162, 153 (1984).

S. Motoo, M. Watanabe, and N. Furuya, "Gas Diffusion Electrode of High Performance," J. Electroanal. Chem. 160, 351 (1984). 
T.E. Springer, T.A. Zawodzinski, and S. Gottesfeld, "Polymer Electrolyte Fuel Cell Model," J. Electrochem. Soc. 138, 2334 (1991).

E.A. Ticianelli, J.G. Berry, and S. Srinivasan, "Dependence of Performance of Solid Polymer Electrolyte Fuel Cells with Low Platinum Loading on Morphologic Characteristics of the Electrodes," J. Appld. Electrochem. 21, 597 (1991).

D.M. Bernardi and M.W. Verbrugge, "A Mathematical Model of the Solid-PolymerElectrolyte Fuel Cell," J. Electrochem. Soc. 139, 2477 (1992).

Z. Poltarzewski, V. Alderucci, G. Maggio, N. Giordano, A. Fasulo, and P. Staiti, "Influence of Electrodic Properties on Water Management in a Solid Polymer Electrolyte Fuel Cell," J. Appld. Electrochem. 22, 663 (1992).

Z. Poltarzewski, P. Staiti, V. Alderucci, W. Wieczorek, and N. Giordano, "Nafion Distribution in Gas Diffusion Electrodes for Solid-Polymer-Electrolyte-FuelCell Applications," J. Electrochem. Soc. 139, 761 (1992).

M.S. Wilson and S. Gottesfeld, "High Performance Catalyzed Membranes of Ultra-Low Pt Loadings for Polymer Electrolyte Fuel Cells,"' J. Electrochem. Soc. 139, L28 (1992). 


\section{APPENDIX IXA: A RETROSPECTIVE OVERVIEW OF FC- TECHNOLOGY DEVELOPMENTS}

\section{IXA-1. FC Technologies, 1985-1994}

The PAFC - The technology status of FCs was summarized in the 1985 AFCWG report. ${ }^{1}$ A detailed discussion of the water-cooled IFC PAFC stack in 1985 was included. ${ }^{2}$ The pressurized electric utility IFC system operated at a mean cell temperature of $205 \mathrm{C}$ at 8.2 atma. Using ribbed-substrate stack technologies developed in the late 1970s with anodes containing $0.25 \mathrm{mg} / \mathrm{cm}^{2}$ of Pt loading (later $0.1 \mathrm{mg} / \mathrm{cm}^{2}$ ) and binary Pt-alloy cathodes initially with $0.5 \mathrm{mg} / \mathrm{cm}^{2}$ loading, it was considered to be capable of an end-oflife performance of $0.73 \mathrm{~V}$ at $216 \mathrm{~mA} / \mathrm{cm}^{2}$. Pt alloys with minor percentages of non-noble metals ${ }^{3,4}$ such as $\mathrm{Va}$ and $\mathrm{Cr}$ had been developed which showed activities up to $50 \mathrm{mV}$ greater than that of pure Pt. Ternary Pt alloys had also been developed. ${ }^{5}$ The alloying component showed surprising stability, far beyond that predicted by thermodynamic considerations. ${ }^{6}$

The 1985 report $^{2}$ showed that improvements resulted from better electrode mixes and from the use of an alternative cell structural configuration with reduced IR drop. As in the earlier ribbed-substrate stack configuration, provision was made for sufficient electrolyte volume to operate $40,000 \mathrm{~h}$. Other methods for reducing cell and intercell IR drops were also being effected. Mean decay rates in the 1,000-2,000-h time frame were about $10 \mathrm{mV} / 1000 \mathrm{~h}$, following a linear log vs time relation for long-term operation. Subscale cells with special compositions had operated at twice the rated current density

\footnotetext{
1 "Assessment of Research Needs for Advanced Fuel Cells," S.S. Penner ed., Energy-The International Journal 11, 1-230 (1986).

${ }^{2}$ AJ. Appleby, Energy-The International Journal 11, 13-94 (1986).

${ }^{3}$ EPRI Staff, "TAG ${ }^{\text {TM }}$ Technical Assessment Guide", EPRI Report P-2410 SR, Electric Power Research Institute, Palo Alto, CA (May 1982).

${ }^{4}$ D.A. Landsman and F.J. Luczak, US Patent Nos. 4,316,944 (2/23/82) and 4,373,014 (2/8/83).

${ }^{5}$ F.J. Luczak and D.A. Landsman, US Patent No 4,447,586 (8/5/84).

${ }^{6} \mathrm{M}$. Pourbaix, "Atlas of Electrochemical Equilibria at $25^{\circ} \mathrm{C}$," National Association of Corrosion Engineers, Houston, TX (1966).
} 
(432 $\mathrm{mA} / \mathrm{cm}^{2}$ ) with acceptably small decay after $800 \mathrm{~h}$ of operation. By 1992, performance was up to $40 \mathrm{mV}$ and mean decay rates were lower than in $1985.7,8$

In 1985, there was little public knowledge about the performance of the proposed $\mathrm{PC}^{\mathrm{TM}} 25$ cell. Figure $2.14-11$ of the 1985 report $^{2}$ contained information on subscale cell performance as a function of time at a current density of $216 \mathrm{~mA} / \mathrm{cm}^{2}(200 \mathrm{ASF}){ }^{*}$ Initial decay was about $4 \mathrm{mV} / 1,000 \mathrm{~h}$ between 3,000 and $4,000 \mathrm{~h}$; for logarithmic decay, ${ }^{2}$ this change may only represent a decay of $40 \mathrm{mV}(\sim 6 \%$ increase in heat rate) from 1,000 to $40,000 \mathrm{~h}$. Early cell performance indicated about $0.67 \mathrm{~V}$ at $216 \mathrm{~mA} / \mathrm{cm}^{2}$ and $0.62 \mathrm{~V}$ at 325 $\mathrm{mA} / \mathrm{cm}^{2}$. Single-cell performance reached $0.75 \mathrm{~V}$ at $242 \mathrm{~mA} / \mathrm{cm}^{2}$ by $1992 .{ }^{2}$ With short stacks, $0.65 \mathrm{~V}$ at $216 \mathrm{~mA} / \mathrm{cm}^{2}$ was attained with a decay rate to $4,500 \mathrm{~h}$ of $4 \mathrm{mV} / 1,000 \mathrm{~h}$. ${ }^{7}$ These improvements have led to reduced weight and volume of the PC25C with decreased degradation rate. The increase in stack-power density with time (see Sec. IXA-2) projected to 1998 corresponds to a $7 \% / y r$ performance increase.

The learning-curve parameter assumed in Ref. 2 was $b=0.8$ although $b=0.6$ may be preferable (cf. Chapter XI). Reductions in volume, weight and costs of major components such as heat exchangers and inverters represent improvements in technology, materials and production techniques. An excellent example is a decrease in inverter cost from about $\$ 2,500 / \mathrm{kW}$ in 1980 to $\$ 75 / \mathrm{kW}$ today, which is about $50 \%$ less than was predicted in 1980.

The reduction in cost and increase in reliability are illustrated by a comparison between the $\mathrm{PC}^{\mathrm{TM}} 25$ and the $\mathrm{PC} 18$, which is a smaller $40-\mathrm{kW}$ experimental on-site precursor of the PCTM25. A production run and a field test of the PC18 were completed in

\footnotetext{
7"Advanced Water-Cooling PAFC Development," IFC Final Report DE/MC/24221-3130, South Windsor, CT (September 1992).

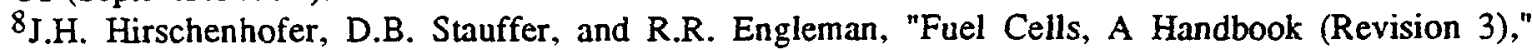
DOE/METC-94/1006 (DE94004072), National Technical Information Service, U.S. Department of Commerce, Springfield, VA (1994).

${ }^{*}$ Mislabeled as $0.66 \mathrm{~V}$ (see Fig. 16-6 of Ref. 8).
} 
1985 for 49 units at U.S. sites, 3 at Japanese sites, 1 in Canada, and 1 in Mexico City. The PC18 weighed $8,000 \mathrm{lb}$ and cost about $\$ 16,500 / \mathrm{kW}$ in mid-1994 dollars, which is more than 4-5 times the cost of an early $\mathrm{PC}^{\mathrm{TM}} 25$. The longest operating run of the PC18 was $2,165 \mathrm{~h}$ (October 1984) and was limited by cooling-system maintenance requirements. Many recent $\mathrm{PC}^{\mathrm{TM}} 25$ runs have been longer than $6,000 \mathrm{~h}$.

As a catalyst support and construction material, graphite is an essential component of the PAFC cathode. In 1985, the pressurized PAFC was operating close to its materials limits. Slow graphite corrosion depends on the absolute electrode potential and on the local water-vapor partial pressure. Both decrease more under atmospheric pressure than for pressurized conditions at the same cell temperature and potential. ${ }^{2}$ Improved materials have acceptable decay rates and lives under pressurized conditions ${ }^{2,7}$ and also perform satisfactorily in atmospheric on-site PAFC units. Even in 1985, a 24-cell on-site short stack operated continuously for $25,000 \mathrm{~h}$. Operating lives exceeding $40,000 \mathrm{~h}$ may be expected for stack components. The ultimate life-limiting factor without addition (as in Fuji Electric Company PAFC stacks) may be electrolyte evaporation, especially in stacks operating at atmospheric pressure, which require higher air volumes than pressurized systems.

A Retrospective of Japanese PAFC Development - In 1975, the U.S. had a 10-year lead on the Japanese with the initiation of a 1-MW system. This lead disappeared in the absence of further U.S. operations of large pressurized PAFC systems. The U.S. effort became dormant after failure of the New York City 4.5-MW demonstrator to produce electricity following system process and control (PAC) tests between November 1981 and June 1983. On the other hand, construction of the Goi 4.5-MW demonstrator was started in 1980 and underwent completion PAC tests from October 1981 to October.1982. This unit generated 2 MW in April 1983 and full power in February 1984. 
In the early 1980s, potential Japanese developers had access to U.S. Government and industry reports and to the U.S. patent literature. After deciding on development of the PAFC, the Japanese avoided U.S. mistakes in construction. U.S. reports indicated that only pure graphite was appropriate for bipolar plate material and that it performed unreliably if the open-circuit potential was reached at FC operating temperatures, especially under pressurized conditions. The Japanese chose a commercially available carbonsupported $\mathrm{Pt}$ as catalyst and graphite as support and construction material. They understood the problem of electrolyte evaporation and chose a ribbed substrate stack as electrolyte reservoir that did not require refilling during the design stack life. The refilling of electrolyte at appropriate service intervals was accepted as an option.

Other FC Technologies - In 1985, the alkaline FC (AFC) was used in the spaceshuttle orbiter vehicle, and cells based on early technology were examined overseas. ${ }^{9}$ Since 1985, the AFC has been improved in connection with defense and space applications. The 1985 PEMFC used costly high-Pt-loading electrodes. Adaptation for use with low-Pt-loading electrodes was recommended. ${ }^{10}$

In 1985 , the $\mathrm{MCFC}^{11}$ and SOFC ${ }^{12}$ were still at the laboratory testing stage. IFC with DOE support was engaged in performance and decay evaluations of small MCFC stacks. ERC had demonstrated internal reforming in single cells. At IGT, new materials technology and improved cells were being developed while MCP was formed. At Westinghouse, plans had been formulated for the development of tubular SOFC $3-\mathrm{kW}$ demonstration units operating on NG. Planar SOFCs of the monolithic type developed at ANL (since 1984) were at the pure research stage. ${ }^{12}$

9J.O'M. Bockris and A.J. Appleby, Energy - The International Journal 11, 95-135 (1986).

${ }^{10}$ A.J. Appleby and E.B. Yeager, Energy - The International Journal 11, 137-152 (1'986).

11J.R. Selman, Energy - The International Journal 11, 153-208 (1986).

12J.T. Brown, Energy - The International Journal 11, 209-229 (1986). 
Both the U.S. and Japan now have strong MCFC-commercialization programs (cf. Chapters I, II, III, and V), while the tubular SOFC is being scaled up from $25 \mathrm{~kW}$ to larger units.

\section{IXA-2. FC Systems, 1985-1994}

Hydrocarbon-FC Systems - $\mathrm{CO}_{2}$ rejection by the PAFC and operating temperatures $\geq 100 \mathrm{C}$ make it relatively resistant to poisoning by small amounts of $\mathrm{CO}$. It has been operated on $\mathrm{NG}$ and light $\mathrm{HC}$ reformate after low-temperature water-gas shifting. Waste heat is available to raise steam for this purpose. A high steam-to-carbon ratio of 3:1* will drive the reforming process at about $800 \mathrm{C} .^{13}$ The use of waste heat to supply this steam saves $12.8 \%$ of the total reforming-fuel requirements or more under operating conditions, thus increasing overall system efficiency.

The FC operating on NG or light HCs was viewed as a complete system in which the electrochemical DC generator (the FC stack) was integrated with an efficient BOP, which includes systems for fuel desulfurization, steam production, reforming, water-gas shifting, and enthalpy recovery.

System developments included the 9-year TARGET (Team to Advance Research on Gas Energy Generation, 1967-1975) program, supported by 32 gas-utility members of the AGA and what was then the Power Systems Division of Pratt \& Whitney Aircraft. The goal was development of a $12.5-\mathrm{kW}$ peak, $0.5-\mathrm{kW}$ mean PAFC unit for on-site cogeneration in household use and designated PC11 ${ }^{2}$ with low capital cost (about $\$ 150 / \mathrm{kW}$ in 1967 dollars or $\$ 650 / \mathrm{kW}$ in 1993 dollars) for a mass-produced unit. The TARGET

\footnotetext{
*The theoretical requirement is $2: 1$ for methane reforming with completion of the shift reaction to form $\mathrm{CO}_{2}+4 \mathrm{H}_{2}$. Some excess steam is needed to drive the reaction. Reduction of the ratio (e.g., from 3.5:1 to 2.5:1) increases system efficiency. A ratio of $2.5: 1$ is used at ERC for indirect internal reforming in the MCFC. The theoretical value for direct internal reforming, without shifting of $\mathrm{CO}$ and with immediate oxidation of $\mathrm{H}_{2}$ to give more steam, is $1: 1$.

${ }^{13}$ H. Ishioka. T. Koshimizu, H. Miyoshi, and Y. Mizumoto, Ext. Abs.1990 Fuel Cell Seminar, Phoenix, AZ, November 1990, p. 318, National Fuel Cell Coordinating Group, Washington, DC (1990).
} 
program was followed by development of a 40-kW, on-site PC18 PAFC system with GRI support and also a 1-MW electric utility pre-prototype (PC19) which was operated in 1977. Next, 4.5-MW demonstrators were built in New York City and Goi in the early 1980s. By 1985, preliminary designs for the 11-MW pressurized electric utility PC23 and the on-site atmospheric-pressure 200-kW PCTM 25 had been completed. ${ }^{2}$

FC Systems Logic - FC anodes operating on reformate have an upper limit for $\mathrm{H}_{2}$ utilization since its partial pressure is reduced as the fuel-gas mixture passes through the anode chamber. The net current density decreases at constant operating potential as $\mathrm{H}_{2}$ fuel utilization (FU) increases. In the PAFC, the ratio of residual $\mathrm{CO}$ to $\mathrm{H}_{2}$ also increases until there are further current-density losses from local anode poisoning. In all FCs operating on reformate, increasing $\mathrm{H}_{2} \mathrm{FU}$ beyond a limiting value leads to diminished performance. In the PAFC, a practical upper limit of about $85 \%$ may be achievable at $190 \mathrm{C}$ if the initial CO concentration is reduced by water-gas shifting to $1.5 \%$. The anode-exit fuel stream in the reformer burner provides enthalpy for the reforming reaction and allows $80 \% \mathrm{FU}$ under practical conditions. ${ }^{*}$

With the possible exception of methanol, all FCs operating with conventional carbon-containing fuels require a fuel-processing plant. HTFCs cannot directly oxidize HCs, particularly the stable methane. In both the MCFC and SOFC, $\mathrm{H}_{2}$ is more rapidly oxidized than methane. If pure HCs are used as fuels, irreversible carbon deposition via cracking may occur. With the addition of $\mathrm{CO}_{2}$ or steam, this deposition may be reversed:

$$
\begin{array}{llll}
\mathrm{C}+\mathrm{CO}_{2} & \rightarrow & \mathrm{CO} & \text { (reverse Boudouard reaction) } \\
\mathrm{C}+\mathrm{H}_{2} \mathrm{O} & \rightarrow & \mathrm{CO}+\mathrm{H}_{2}, \\
\mathrm{CO}+\mathrm{H}_{2} \mathrm{O} & \rightarrow & \mathrm{CO}_{2}+\mathrm{H}_{2} & \text { (water-gas shift reaction). }
\end{array}
$$

\footnotetext{
*If the product of the fuel-processing system is pure $\mathrm{H}_{2}$ produced by water-gas shifting of reformate followed by pressure-swing adsorption, the low-BTU pressure-swing exit stream must also be burned to provide enthalpy for reforming. This solution was rejected as being not sufficiently energy-efficient.
} 
$\mathrm{H}_{2}$ is rapidly consumed to produce more steam in the $\mathrm{FC}$, which drives the three reactions to the right. Steam is added to prevent $\mathrm{C}$ deposition. With reforming catalysts at $650 \mathrm{C}$, the space velocities for steam reforming of $\mathrm{HCs}$ (including methane) are at least as rapid as typical hydrogen-oxidation rates at MCFC anodes. If these catalysts are incorporated in the MCFC anode area, driven internal steam reforming and water-gas shifting occur with coupled $\mathrm{H}_{2}$ oxidation. On the SOFC anode catalyst at $1,000 \mathrm{C}$, the rate of endothermic steam reforming may be so high that heat transfer limits the process and overcools the anode at the leading edge.

Whereas the PAFC is an electrochemical $\mathrm{H}_{2}$ reactor with an integrated chemical processing plant, an HTFC may be an electrochemical reactor with internal fuel processing. The enthalpy of combustion of the anode-exit stream is not used in reforming, ${ }^{2}$ but it may be employed for preheating, steam raising or auxiliary power. When internal reforming is used, the FC behaves thermodynamically as if the carbonaceous fuel is used directly, i.e. the electrical efficiency is the cell voltage divided by $-\Delta \mathrm{H}_{\mathrm{C}} / \mathrm{F}$, where $\Delta \mathrm{H}_{\mathrm{c}}$ is the enthalpy of combustion and $\mathrm{F}$ the Faraday in appropriate units. Internal reforming reduces the coolingload requirements on the stack since the enthalpy of the endothermic reforming reaction provides some cooling. HTFC developers may prefer other systems which use the anodeexit stream to provide enthalpy for external reforming. As in the PAFC, separate water-gas shifting is unnecessary.

FC Reliability Issues - An important problem in U.S. electric utilities acceptance of experimental PAFC systems was a perception that the technology was untried and unreliable. Although full-scale cells and short stacks had operated well for several thousand hours, this perception persisted. Older laboratory cells had operated from 40,000 to more than $100,000 \mathrm{~h}^{2}$ Whereas laboratory cells and short stacks often operate continuously under constant-load conditions, utility-plant stacks must operate at varying 
loads discontinuously. Horizontal and vertical scale-up may be accompanied by unpredicted failures and degradation, especially under pressurized conditions.

On the basis of laboratory results, developers maintained that the FC-stack was the most uncertain element of the technology but was the least likely component to fail. Failures were expected in the BOP and could result from problems with high-temperature gas circulation, steam generators, turbocompressors, and cooling-system components. Experience with the 40-kW system had demonstrated this BOP unreliability by 1985 . Furthermore, an on-line corrosion problem occurred on eight $650-\mathrm{kW}$ stacks at Goi with serious performance degradation. More recently, the $200-\mathrm{kW}$ units have proved to be very reliable (cf. Secs. V-7 and IX-1).

\section{IXA-3. The MCFC in 1985}

Workers at IFC had tested a series of externally manifolded laboratory shortstacks and had shown that they lost electrolyte by osmotic pumping through the porous manifold gaskets. The driving force was reduction of $\mathrm{O}_{2}$ in air on the outside of metal bipolar plates, which produced $\mathrm{CO}_{3}=$ externally; alkali metal ions completed the electrical circuit. Fuel oxidation took place in the opposite direction. The net result was pumping of molten carbonate out of the cell. Electrolysis of carbonate occurred across the potential gradient on the stack gasket and caused a loss of $\mathrm{CO}_{3}=$ as $\mathrm{O}_{2}$ and $\mathrm{CO}_{2}$ at the positive end of the stack, migration of alkali-metal ions to complete the circuit, and production of alkali metal at the negative end which immediately reacted with $\mathrm{O}_{2}$ and $\mathrm{CO}_{2}$ to form more carbonate. As a result, alkali carbonate appeared to be pumped to the negative end of the stack. ${ }^{*}$

\footnotetext{
*The chapter on the MCFC in the 1985 report mistakenly stated that pumping was to the positive end. This statement reflects both the difficulty in obtaining accurate information and the fact that the problem was incompletely understood.
} 
Experience with small pressurized stacks (at 5 atma) was limited to work at IFC. A bubble-pressure barrier had been incorporated in the cell anodes to prevent fuel crossover under pressurized conditions. Proprietary details included stack-component construction such as seals including metal-cell-edge seals and electrode and matrix characteristics. Other hardware developers (ERC and, to early 1984, GE) started stack development in 1985 . The GE repeat-cell design was internally manifolded ( a version is illustrated in Ref. 2). A proposed design with multiple manifolding holes on each side of a scale-up bipolar plate is given in Ref. 14.

Coal Systems - The major attraction of the MCFC to DOE in 1985 was its potential use with coal-derived gas in an oxygen-blown integrated gasifier combined cycle (IGCC) system, which operates at elevated pressure with high system efficiency. The MCFC was to serve as a topping cycle for a gas turbine, which pressurized the FC to 8-10 atma and was in turn combined with a steam cycle operating on gas-turbine exhaust gases and waste heat. The steam cycle would supply steam to the gasifier. Electricity would be produced from the FC via an inverter and also from the shafts of the gas and steam turbines. Systems studies had indicated that HHV efficiencies over 50\% might be attained, about 5\% higher than those with the IGCC system alone. The MCFC system was expected to have lower emissions but higher capital cost clean-up systems.

Internal Reforming - ERC showed that the space velocities in an atmospheric pressure MCFC were sufficiently low to operate with internal reforming of a mixture of steam and NG with a reforming catalyst in the anode chamber. The resulting MCFC is attractive as a small on-site power system. The system durability was not known, but the catalyst did slowly lose effectiveness as it became covered by a carbonate film.

\footnotetext{
${ }^{14}$ General Electric Staff, "Development of Molten Carbonate Fuel Cell Power Plant," published as DOE Report DOE/ET/17019-20, Vol. 1, National Technical Information Service, US Department of Commerce. Springfield, VA (March 1985).
} 
A simplified MCFC internal reforming system designed by ERC and FluorDaniel, which requires only one heat exchanger compared with 11 in the $40-\mathrm{kW}$ PC18, is described in Ref. 1. Because of internal reforming using $\mathrm{FC}$ waste heat, the system may be regarded as operating on NG. The LHV of methane (NG) is $100.3 \mathrm{~kJ} /$ equivalent so that $-\Delta \mathrm{H} / \mathrm{F}$ is $1.040 \mathrm{eV}$. Hence, a cell operating at $0.75 \mathrm{~V}$ with internal reforming using FC waste heat will have an in-cell efficiency of $72 \%$. If the FU is $75 \%$, the gross DC system efficiency before corrections for parasitic losses will be 54\%, which exceeds that of a PAFC with external reforming. Because of its simplicity, it was believed that this system could be built for about $\$ 1,780$ mid-1994 dollars in a pilot-production run of $1001.8-\mathrm{MW}$ units.

Materials Issues - A major problem identified by IFC was dissolution of the Lidoped $\mathrm{NiO}$ cathode, which was accompanied by precipitation of $\mathrm{Ni}$ particles (dendrites) between the electrodes towards the anode under reducing conditions. The result may be a short, well before a significant $\mathrm{Ni}$-cathode inventory is lost. Since $\mathrm{NiO}$ dissolution is inversely proportional to oxide-ion activity, it is proportional to the $\mathrm{CO}_{2}$ partial pressure. As the result, the cell life may be limited to $5,000 \mathrm{~h}$ at 8 atma when using a reference oxidant composition containing $30 \% \mathrm{CO}_{2}$ (i.e. $\mathrm{P}_{\mathrm{CO}_{2}}=2.4$ atma at low OU). A lesssoluble replacement for lithiated $\mathrm{NiO}$ may therefore be desirable.

Other materials problems discussed in 1985 were corrosion of 316 SS, which requires Ni cladding under wet anode-exit conditions. A marginally better substitute is 310 SS with a higher $\mathrm{Cr}$ content. Anode creep is generally controlled by using sintering inhibitors other than $\mathrm{Cr}$ (e.g., $\mathrm{Al}$ ) in the sintered $\mathrm{Ni}$ anodes; aluminizing had been shown to be effective in protecting bipolar plate edges from corrosion. Experiments at IGT suggested that electrolyte evaporation in small cells maintained at $650 \mathrm{C}$ under standard reactant conditions was unlikely to limit cell life. 
Cell Performance - Performance in small laboratory cells on reference gases (simulated humidified coal gas at $80 \%$ FU or humidified NG reformate at $85 \%$ FU with $15 \% \mathrm{O}_{2}, 30 \% \mathrm{CO}_{2}$ and $55 \% \mathrm{~N}_{2}$ ) was $750 \mathrm{mV}$ at $160 \mathrm{~mA} / \mathrm{cm}^{2}$ and $850 \mathrm{mV}$ at $80 \mathrm{~mA} / \mathrm{cm}^{2}$ at atmospheric pressure, i.e. the polarization slope was $1.25 \Omega-\mathrm{cm}^{2}$. Corresponding figures at $160 \mathrm{~mA} / \mathrm{cm}^{2}$ and 3 atma were $805 \mathrm{mV}$ (slope $=1.125 \Omega-\mathrm{cm}^{2}$ ); at $5 \mathrm{atma}, 830 \mathrm{mV}$ (slope=1.0 $\left.\Omega-\mathrm{cm}^{2}\right)$; and at $10 \mathrm{atma}, 850 \mathrm{mV}\left(\right.$ slope $\left.=1.0 \Omega-\mathrm{cm}^{2}\right)$.

\section{IXA-4. The MCFC and SOFC in the U.S. and Europe, 1985-94}

U.S. - It was believed in 1985 that commercialization failure of the PAFC in electric utility application would reduce sales of all FC systems to utilities. Review of NOMO responses in 1988 showed that planners at the APPA utilities had concluded that the MCFC would become an attractive future power plant with lower capital cost than the PAFC because of its simpler BOP. The high operating temperature of the MCFC permits the use of sensible heat from the stack for reforming. The present MCFC commercialization effort is largely proprietary (see Secs. V-6 and V-8 for details).

Europe - The Netherlands restarted MCFC development in 1986 after interrupting its pioneering program for 15 years. Non-U.S.-Government-sponsored technology was transferred from IGT beginning in 1985-86 under a gas-development cooperation agreement with The Netherlands Energy Organization (NOVEM). The national program, which included IEA-Joule participation, started in 1987. Stack-development work is conducted at ECN in Petten. The total FC Program in 1993 involved 80 man-years with 60 persons working full time. Of these, $70 \%$ worked on MCFCs, $20 \%$ on SOFCs, and $10 \%$ on PEMFCs; total expenditures in 1993 were $\$ 13.5$ million. ECN has MCFC facilities 3 to 5 times larger than those of Ansaldo in Italy. ECN management has proposed to become the European Testing Center for MCFC, SOFC and PEMFC systems up to $10 \mathrm{~kW}$. Performance of laboratory-scale cells at ECN under standard conditions (low anode 
utilization for a standard 70:30 air/ $\mathrm{CO}_{2}$ reference cathode-gas mixture) was comparable to that at IGT. The CEC supported a successful 1-kW IIR pilot stack at ECN in 1989. A 1000-cm², ten-cell stack has been operated since November 1990 .

The proprietary ECN FLEXSEP ${ }^{\circledR}$ bipolar plate technology has internal manifolding and superficially resembles the MCP IMHEX ${ }^{\circledR}$ plate. Counter flow through the cells with a co-flow manifold supply was first used; now a counter-flow system with improved temperature distribution is employed. Use of a built-in flexible manifold area and a compliant soft metallic rail around the edges for sealing allows for manufacturing tolerances and thermal expansion. The material is Avesta SS with 25:20:5 Ni:Cr:Mo and $\mathrm{Cu}$. This material has better corrosion resistance than AISI 310S (4:28:2 Ni:Cr:Mo). It is nickel-coated on the anode side and aluminized by high-temperature chemical vapor deposition around the edges for corrosion protection. Electroplated nickel coatings ( $50 \mathrm{~mm}$ thick) have been successfully used on iron-based alloys such as the steel in the bipolar plate; less expensive copper coatings are being examined. The bipolar plate consists of a corrugated central part and two gas-distribution frame parts which are TIG-welded. The current collectors are DIN 1.4404 SS, nickel-plated on the anode side. The $\mathrm{LiAlO}_{2}$ matrix tape contains fibrous $\mathrm{Al}_{2} \mathrm{O}_{3}$ for reinforcement. System analyses show that pressurized stacks containing up to 125 large cells are possible. ${ }^{15,16}$

Scale-ups of components from $1000-\mathrm{cm}^{2}$ active area to $3352-\mathrm{cm}^{2}(47 \mathrm{~cm}$ along a 5-hole manifolding, width $=41 \mathrm{~cm}$ ) and finally to $1 \mathrm{~m}^{2}$ have been carried out. The last was accomplished early in 1994 by stretching the smaller plate by a factor of three along its width. A continuous tape-casting machine for these sizes was installed in 1992. Distribution of gas-flow in internally-reforming stacks of this type has been modeled. A

\footnotetext{
$15 \mathrm{~K}$. Joon, P.C. Van der Laag, and D. Jansen, Plenary Session. International Fuel Cell Conference Proceedings, p. 25, MITI, Tokyo (1992).

${ }^{16}$ L.A.H. Machielse, R.J. Boesma, C. Croon, W.M.A. Klerks, and G. Rietveld, International Fuel Cell Conference Proceedings, p. 269, MITI, Tokyo (1992).
} 
proof-of-principle, three-cell 1.0-kW stack with full-scale components was tested in 1992 and was followed by a 20-cell endurance test. A $10-\mathrm{kW}$ pressurized (4 atma), 0.34- $\mathrm{m}^{2}$, 33-cell stack was tested for 2,000 hours, including one thermal cycle, in early 1994 . This is to be followed by a 50-kW stack in 1994 and two $250-\mathrm{kW}$ MCFC units by 1995 . One of these was expected to operate on coal gas, the other on NG with CHP. The first (coal gas energy transformation in an MCFC, COGENT-MCFC) is to be operated on gas from the 250-MW IGCC plant at Buggenem (operational in 1994). Following these proof-ofconcept demonstrations, a proof-of-producibility program was envisaged with production of about $25 \mathrm{MW}$ of $500-\mathrm{kW}$ systems per year.

The Netherlands program continues to put strong emphasis on fundamental research at ECN and at Delft Technical University. The mechanism of $\mathrm{NiO}$ cathode dissolution and the effects of additives on lifetime were examined. Additions of small amounts of alkaline earth metal oxides or carbonates increase melt basicity and have been shown to give a $40 \%$ reduction in dissolution rate. New cathode materials have been examined, particularly lithium cobaltate and lithium ferrite. The latter shows essentially zero solubility but poor performance, which is presumably due to inferior conductivity. Lithium cobaltate has about $10 \%$ of the solubility of $\mathrm{NiO}$ but, in spite of its lower conductivity, it has a performance only about $50 \mathrm{mV}$ lower than the latter. Improvements in the structure and performance of $\mathrm{Ni}-\mathrm{Cr}$ anodes have also taken place; $6 \%$ levels represent an optimum structure for long-term porosity retention. $\mathrm{Ni}$ - $\mathrm{Al}$ anodes with enhanced creep performance are receiving attention. Other life-limiting issues have been reviewed, and the corrosion of $\mathrm{Ni}$ has been examined. Particular emphasis has been placed on improving electrode-performance models.

The ECN SOFC program is carried out in collaboration with other European institutions (Eniricherche, Siemens, GEC-Ahlstrom, Imperial College, Holec, Ridderkerk, 
Loughborough University, University of Aveiro, Rhone-Poulenc, TNO, NOVEM, the Joule Project, and IEA programs). Materials developments (electrolyte components and cells up to $400 \mathrm{~cm}^{2}$ ) and testing are the major activities. For the PEMFC program, there is similar collaboration with Siemens, Johnson-Matthey, and Rolls-Royce.

In 1990, ECN founded Brandstofcel Nederland B. V. (BCN) as a potential MCFC manufacturing arm, with $4 \%$ ownership by ECN, $24 \%$ by Stork (annual gross $\approx \$ 2.2$ billion/yr in industrial machinery including cogeneration), $24 \%$ Schelde (annual gross $\approx$ $\$ 600$ million/yr in naval shipbuilding and cogeneration). $\mathrm{BCN}$ is co-financed by NOVEM (50\%), The Netherlands Electricity Board (program launcher, 16\%), the CEC (16\%), Spain, and others in a $\$ 51$ million program. $B C N$ is licensed by IGT and uses also indigenous technology while collaborating with MCP, Siemens, and Ansaldo. The objective was MCFC manufacture, demonstration, and production. Since 1992, the attitude has become more sanguine. ECN believes the MCFC must compete in price with GTCCs $(\$ 750-850 / \mathrm{kW})$ and cannot do so if a $250-\mathrm{kW}$ stack continues to contain $1 \mathrm{~m}^{3}$ of materials (about 6 metric tons at $\$ 8-10 / \mathrm{kg}$ ). Weight reductions are being made, however. The FLEXSEP ${ }^{\circledR} 1-\mathrm{m}^{2}$ bipolar plate (without current collectors) contains only $6 \mathrm{~kg}$ of ordered materials. Plates from U.S. developers are heavier; the experimental IHI plate weighs about $20 \mathrm{~kg} / \mathrm{m}^{2}$ and the Hitachi plate is even heavier.

Workers at ECN and BCN have concerns about stack life. For example, at 1 atma, ECN conservatively estimates the following lifetimes for various elements (in thousands of hours with system gases): $\mathrm{NiO}$ cathode, 25 ; lithium cobaltate, $120 ; \mathrm{Ni}-\mathrm{Cr}$ and $\mathrm{Ni}-\mathrm{Al}$ anodes, 40 and 80 , respectively; lithium aluminate matrix $>40$; electrolyte as limited by evaporation, 6-10; bipolar plate, $>10,20$ and 20 for the anode and cathode sides, and the wet seal, respectively. At 4 atma, the figures are: cathodes, 6 and 90; anodes, 40 and 80; matrix, >40; electrolyte, 18; bipolar plate areas $>10,20$, and 20 , respectively. These figures are based on laboratory data taken on cells representing outlet- 
gas temperature conditions at $700 \mathrm{C}$ in real co-flow systems. They differ from U.S. predictions taken on reference gases (lower water content and therefore lower hydroxide vapor pressure in the evaporating stream) in small cells maintained at $650 \mathrm{C}$. The suggested life limitation on the anode side of the nickel-clad bipolar plate is due to spalling of the coating on water formation at the SS oxide layer, which is said to be a random, medium-term effect.

At $\mathrm{BCN}$, further demonstrations have been put on hold. There is also concern about the needed start-up capital, estamated by the CEC at $\$ 1.7$ billion (of which the Commission could supply 10\%) for MCFCs, SOFCs, and PEMFCs. Experts at BCN believe that $\$ 330$ million are required to launch the MCFC.

\section{IXA-5. SOFC Issues}

Westinghouse - The only SOFC with near-term commercialization potential is the Westinghouse tubular design, which was devised in 1980 to solve connection and fabrication problems using known concepts. The system has gone through a number of changes with time to improve performance and allow scale-up (see Sec. V-9 for details).

Planar SOFC Developments - Planar technology using thin components (perhaps with metal bipolar plates) may have high performance per unit area, low weight and low costs. The earliest planar systems were those of Ztek (1980s) and had small circular cells and innovative (presumably metal) bipolar plates, with components made by plasma spraying. The system was manifolded internally via holes, and the bipolar plates had segmental ripples to make contact and allow space for gas circulation. This system is now reported to be at the $10-\mathrm{kW}$ stack- development stage (compare Sec. V-10).

TMI developed an interscience radial flow (IRF) SOFC which is similar to the Ztek system; it has internal manifolding via holes and outward radial co-flow of reactant gases in each cell, as well as metal bipolar plates. This system was originally developed at Sohio- 
BP during the 1980s and was then acquired by TMI. A unique feature is the use of particulate rather than sintered air electrodes, which is claimed to remove the need for a matched CTE. It is claimed that the TMI systems operates over a wide range of conditions by having mixed ionic and electronic conductivity.

Another early planar system was the monolithic SOFC of ANL (1983-84) in which all stack components are ceramics. These are piled into a stack in the green state and cosintered (including the manifolding) in the manner employed for ceramic heat exchangers. The system is licensed to AlliedSignal. For details, see Sec. V-2.

Ceramatec Inc., owned by Elkem of Norway, has operated several multi-cell stacks of a few $\mathrm{kW}$ under known FU conditions. The designs are based on the use of an LSC or LCC ribbed bipolar plate in a cross-flow arrangement. For details, see Sec. V-4.

SOFC developers may use BOPs with high-temperature blowers. It is generally acknowledged that costly superalloy or ceramic heat exchangers may be required for 1000 $\mathrm{C}$ operation. At $900 \mathrm{C}$ or less, thinner components become usable to avoid loss of performance. This approach may make the use of relatively inexpensive, low-resistance superalloy bipolar plates feasible after coating with a conducting oxide layer on the cathode side.

\section{IXA-6. PEMFC Issues}

For details see the discussions by Ballard (Sec. V-3), Dow/Ballard (Sec. V-5), and the research recommendations in Sec. DX-4.

\section{IXA-7. Accelerated Life Testing}

Accelerated life testing of short stacks under modified plant operating conditions may prove to be helpful in determining real lifetimes under conditions of normal use. 
Successful use of such a test could allay concerns about reliability of the electrochemical part of the generator technology, i.e. the part which is least familiar to utility engineers. 



\section{PROGRAMS IN UNIVERSITIES AND NATIONAL LABORATORIES ON TEACHING AND TRAINING IN SUPPORT OF A SIGNIFICANT FC- SYSTEM COMMERCIALIZATION EFFORT}

\section{X-1. University Programs in Support of Commercialization}

Successful commercialization of any technology based on advanced scientific and engineering disciplines requires competent and well trained personnel. The disciplinary bases for FC systems include the materials sciences (especially composites, alloys, catalysis, corrosion-resistant properties, and electrical and mechanical properties of electrolytes and electrodes), electrochemistry, fuel reforming, power-systems engineering, mass and heat transfer, quality control, manufacturing, and cost-reduction strategies. Of these, except for a few centers of excellence, electrochemistry has been relatively neglected in the U.S. Furthermore, there are no dedicated university research centers dealing with development and optinization of FC systems as an integrated, goaloriented activity.

A significant increase in U.S. academic teaching, training and research appears to be a useful change in connection with a major FC-commercialization effort. It can probably be accomplished through a definition of programmatic needs that will lead to identification of electrochemistry by a responsible funding agency as a critical and neglected area of university activities. This type of identification may then be expected to be followed by augmented funding for university research with resulting growth of the needed university programs. However, a change of emphasis restricted to electrochemistry as a basic discipline is not likely to have a significant impact on FCsystem commercialization schedules, as will now be elaborated by summarizing current activities from the perspective of normal university functions. 


\section{X-1.1. Education and Teaching Needs}

The establishment of specific programs for teaching and training to support rapid FC development and commercialization within the university system is complicated for the following reasons: (i) The specific needs are varied and diverse because four different FC-system technologies are being pursued and each of these is at a different stage of development and commercialization. (ii) The education and training of students at universities, except at dedicated centers of excellence, may not complement needs for FC commercialization because the aims of university researchers are different from those of FC-system manufacturers. (iii) Industry research and development generally require solutions of specific problems that are highly proprietary, whereas universities deal with long-term, generic research. The industry developers may be hesitant to disclose or define important problem areas for public release. (iv) The time required to conduct research and development in universities is long compared to the time available for solving specific and critical needs of FC development, especially those related to rapid commercialization. (v) Training in multiple disciplines for direct application to FC technologies is not generally available within the university system. (vi) Support by government, industry and universities specifically for FC-system education and training is very limited, if it exists at all. (vii) There is at present a clear lack of recognition by most university faculties and students that FC systems represent an important emerging and growing technology and that industry is likely to provide timely employment opportunities for long-term, rewarding careers.

The primary need for the research and development organizations, utilities and industries working on FC technologies is well-educated individuals trained in disciplines relevant to FC development and applications. These areas include electrochemistry, chemistry, materials science, electrical engineering, environmental science, design, mechanical and chemical engineering, among others. Perhaps the greatest immediate 
need is not for individuals specifically trained for FC-system commercialization, but rather for individuals who have the ability and experience to conduct systematic experimentation leading to the timely solution of the multiplicity of problems that are likely to arise in a commercialization effort.

\section{X-1.2. Training and Educational Support}

A program for training and educating students based on current employment opportunities and the status of FC-system commercialization should include the following: (i) In-depth education and training of individuals in specific disciplines related to one and preferably two or three areas that are currently utilized in manufacture and sales. (ii) A general introduction and involvement of many students, faculty and research administrators to $\mathrm{FC}$ science and technologies. (iii) The cooperative involvement not only of university personnel but also of governmental agencies, government-supported institutions, privately supported institutions, utilities, and industry in the promotion and education of the promise of FC systems.

It is doubtful that a formalized program is required or that it would effectively impact the rapid commercialization effort for FC systems. However, these activities are likely to prove to be of benefit after a pericd of 5 to 10 years.

\section{X-2. The Role of the National Laboratories in the U.S. Fuel-Cell Commercialization Program}

\section{X-2.1. Past Contributions Made by the National Laboratories}

The National Laboratories (NLs) have played a key role in advancing FCs from an expensive device for space use to near-commercial terrestrial applications. Serving as technical experts for DOE, they provided guidance and initiative for many governmentsponsored programs. In the mid-seventies, experts at ANL assisted DOE in the MCFC programs with UTC and GE and, soon afterwards, the SOFC program at Westinghouse. In the eighties, researchers at LANL, ANL and Georgetown Lniversity laid the 
foundation for DOE's transportation program, first helping to build a golf-cart and then an urban bus powered by PAFCs. As a follow-on, the GM/Allison program to develop passenger cars with PEMFCs was established. It should also be noted that fundamental research on PEMFCs at Case Western Reserve University and Texas A\&M has been a major contributor to advancing the potential of PEMFCs for transportation applications.

Researchers at NLs have made major contributions to FC development. At LBL, fundamental properties were investigated of electrocatalysts, porous electrodes, and electrolytes that enhanced the scientific understanding of FC electrochemistry. PNL developed new materials for SOFCs that led to improvements of the tubular SOFC. LANL made significant improvements in PEMFC electrode manufacturing, reduced catalyst loading and reformer technology, which were transferred to the GM/Allison project. ANL invented the monolithic SOFC, which has been licensed by AlliedSignal.

In addition to advancing the technology, the NLs have been playing an important educational role. LBL, which is affiliated with the University of California, has served as a center for training M.S. and Ph.D. electrochemists and electrochemical engineers. All of the NLs have hired recent university graduates as postdoctorate appointees and have assisted in preparing them for industrial or university research careers. Equally important, the NLs have often served as technical resources for private-sector companies and independent organizations seeking information on FCs. Many open presentations and position papers dealing with FCs have been presented and published. A number of the industrial FC developers became active program participants after interactions with experts at the NLs.

As the FC technologies become commercialized, associates in the NLs may be expected to continue to make vital contributions. The strengths of the NLs reside in the knowledge and experience of senior technical experts, outstanding facilities, and independent status. 


\section{X-2.2. Materials and Process Development}

Fuel cells will have to become less expensive to succeed in the market place. The required cost reduction will result from manufacturing larger numbers of improved and progressively lower-cost units. Implicit in the learning curve for mass producing industrial products of all types is improving materials properties and manufacturing methods for the devices.

Industrial developers tend to improve their products incrementally in small steps. The NLs have historically concentrated on exploring fundamental and long-range aspects of the technology. There remain many poorly understood phenomena in the electrocatalysis of the low-temperature FCs and the materials interactions of the hightemperature FCs. New or modified materials and new manufacturing methods will help make FCs less expensive. Workers at the NLs and universities may be expected to lay the foundations for the second and third generations of technology in collaboration with industrial developers.

New developments are expected to result from CRADAs directed by industry or from other contractual arrangements involving NLs, universities and industry that will contribute to the commercialization of new inventions by U.S .companies.

\section{X-2.3. Program Planning and Assessment}

Commercialization of FCs in dispersed stationary power plants is currently occurring, albeit with delays and difficulty because industry cannot absorb the market entry losses by itself. Public sector support may be necessary and is recommended elsewhere in this report. Implementation of the goal of replacing the internal combustion engine in transportation with FCs is likely to be very challenging and will require considerable public support.

The government and organizations such as SCAQMD, EPRI and GRI have in the past tended to rely on internally generated program plans in pursuing their goals. DOE 
currently has a 10-year program plan for FC technology development. Similarly, a New Generation Vehicle Plan is being prepared. The NLs are positioned to prepare or aid in the preparation of these documents based on interactions with industry and their own understanding of the issues involved. As independent experts, workers at the NLs are often called upon to write assessments of different types of FCs for specific types of applications.

\section{X-2.4. Public Education and Awareness}

Acceptance of new technologies with potentially as far-reaching consequences as replacements of stationary power-conversion systems by FC systems or of IC-engines by electrochemical devices will be most readily accomplished if the public is prepared to accept the risks as well as the benefits. Senior staff members from the NLs have increasingly offered public presentations on the merits of FC technologies. This effort requires expansion to reach broader segments of the population.

\section{$\mathrm{X}-3$. Summary Remarks on the Roles of Institutions}

Government - The national government and its agencies, such as the U.S. Department of Energy through its Offices of Basic Energy Research and Fossil Energy, support many research projects in areas related to FC systems. It is anticipated that such research support will continue. Increasing university support for FC projects will generally follow if established university professors propose significant new projects or when new funds become available because of a change in direction toward FC-related research. There are special governmental programs for the support of cooperative research between industry, NLs and universities. A national plan for education and training on FC technologies should best come through the National Science Foundation.

National Laboratories - The NLs involved in FC R\&D have a number of established programs for involving students, post-doctoral fellows and faculty in research 
programs related to FCs but these are used infrequently to support the FC technologies directly. The appointments are generally short-term (6 to 52 weeks), with financial support provided in whole or in part from project funds. There are also available, within DOE and other governmental agencies, graduate fellowships and postdoctoral programs on a competitive basis. This approach for involving faculty, postdoctoral fellows and students is especially effective in providing understanding and experience on FC research, development and technologies.

The NLs appear to be especially well positioned to provide bridge experience and training at the professional level for FC specialists. In addition to an excellent senior staff of professional investigators, these establishments can offer superior facilities and supporting staff to specialists at the pre- or post-doctoral levels for advanced research, possibly with identified industrial needs that are co-funded through CRADAs. Cooperation between the NLs and associated universities should be established to facilitate unique research opportunities for students on issues that have been identified by industrial groups as being of key importance in competitive FC-commercialization efforts.

Utilities and Industry - The utilities and industries often support university students and faculty through contracts on generic research and may offer temporary appointments for university personnel in industrial laboratories. Industry promotions and advertisements on the promise of FC technologies in the media may be useful efforts.

Universities - The universities must provide critical resources aimed at successful development of educational and training programs. Research and development must be conducted in a timely manner to address specific needs and problems. Proprietary aspects must be guarded even while promoting publications. Timeliness is required for university activities if they are to contribute to rapid FC-system commercialization. Education and training of students with multiple disciplinary backgrounds relating to FC 
systems should be encouraged. The major need remains the training of highly adaptable, versatile, accomplished individuals who are ready to tackle any and all tasks relating to FC-system commercialization.

\section{X-4. Establishment of a University-Based Engineering Research Center in FC- System Technology}

The National Science Foundation currently allocates a total of about $\$ 47$ million per year to fund Engineering Research Centers (ERCS) at U.S. universities in about 20 distinct disciplinary areas with an average annual support level of about $\$ 2.3$ million for periods of time ranging from 3 to a maximum of 11 years. The disciplinary areas chosen for support are selected through a complex and exhaustive open competition. With careful planning, it may be possible to succeed in a competitive selection that ultimately leads to the creation of an Engineering Research Center on Fuel-Cell Technologies provided (i) an effective program manager, housed in a university, gains the support, endorsement and cooperation from complementary interdisciplinary departments located in two or more additional universities, (ii) important industrial participants endorse the proposal as being especially useful to their commercialization efforts and (iii) key researchers in the National Laboratories offer to cooperate with the Engineering Research Center because they support the utility of this type of activity.

A representative successful "Advanced Combustion Engineering Research Center" is co-located at Brigham Young University in Provo, Utah, the University of Utah in Salt Lake City, and North Dakota State University. It deals with modeling of industrial fossil-fuel combustors, reduced air emissions and increased conversion efficiencies. It has now operated for 8 years, has funds to expend a total of about $\$ 5.9$ million during its ninth year of operation, has gained support from the State of Utah, various DOE Laboratories, EPA, EPRI, GRI, and about 40 cooperating industrial 
concerns which pay small participatory annual fees (ranging from $\$ 2,000$ to $\$ 15,000$ per annum).

We cannot offer a prescription for founding a particular NSF Engineering Research Center on FC-system commercialization but hold the view that the importance of the topical area of FC-system commercialization, in competition with many other activities that are now funded or will be funded by NSF in the future, is such that a dedicated effort to propose establishment of an Engineering Research Center is likely to have endorsement from AFC2WG members. It is noted that the NSF-funded Engineering Research Centers must be based at universities and cannot be established either in industrial organizations or National Laboratories. The research outputs must be generally publishable. The industrial affiliates will exercise important guidance in developing the research program and may fund special studies through grants leading to preferred research outputs that may be disclosed to sponsors of the research on a restricted basis for brief periods of time. The activities at Engineering Research Centers must be complementary to and not competitive with programs in the National Laboratories. Successful creation of an NSF-sponsored Engineering Research Center implies a desirable level of cooperation among participating industrial affiliates on fundamental research issues that are of general interest without impeding competitive industrial growth.

There should be no presumption of preselection by AFC2WG members of any particular proposal effort. AFC2WG member support will require the right proposal to NSF led by an especially qualified PI. A PI pursuing the goal of a Fuel-Cell System Engineering Research Center might profitably consider each of the following constraints: (i) there should be only a single university consortium with not fewer than 3 or 4 participating universities and including the required interdisciplinary talents (for FC systems, materials science, electrochemistry, reformer capability, requisite power-system 
engineering, design and manufacturing engineering, cost-minimization expertise, etc.); (ii) a substantial expressed interest is required from U.S. manufacturing companies who establish a cooperative industry advisory group to determine research directions and monitor performance on an ongoing basis and the approval of which is a requirement for continuation of funding for the Engineering Research Center to the maximum allowed time period of 11 years; (iii) there must be cooperating researchers in government laboratories; (iv) most important of all, the proposal must survive a stiff competition with all other disciplinary proposals serving other manufacturing and national goals.

A significant university role without the creation of a structure such as an Engineering Research Center is not likely to develop in connection with a national FCsystem commercialization effort. If we are serious about the need of providing preferred treatment for FC-system commercialization because of its singular importance to the national well being, then we must also be serious about expecting that an industryconsortium-backed effort to establish an Engineering Research Center dedicated to FCsystem commercialization can succeed in a national competition against other industrybacked proposals. 


\section{FUEL-CELL PRODUCTION LEVELS AND ASSOCIATED EXTERNAL SUBSIDIES TO MANUFACTURE COST-COMPETITIVE FC SYSTEMS}

For any unsubsidized commercialization activity, it is axiomatic that protagonists working in industry must provide investment-cost estimates, development and implementation plans for the initial period preceding returns on investment, estimates of anticipated product-volume growth, life-cycle costs, and profit projections. An appropriate early measure of the validity of the business plan is provided by the extent to which cost projections before the venture becomes profitable are under budget, within budget or over budget. The importance of projections of this type is well recognized not only by FC-system manufacturers but also by governmental planners. In support of the preceding remark, we cite the following statements contained in a recent $(02 / 14 / 94)$ METC RFP: "Costs versus quantity of fuel cells manufactured shall also be developed. These curves shall be adjusted for the impact on fuel cell costs of the various improvement efforts."

Engineers and scientists concerned with product improvement, quality control and reductions of manufacturing costs are implementers of the improvement efforts. They deal with the "bottom-up" view of the manufacturing and commercialization agenda. It is known from innumerable successful business ventures that the hard and detailed efforts involved in the "bottom-up" approach may ultimately be encompassed by a "top-down" retrospective achievement relation that is often called a learning curve (see Sec. XI-6 for a detailed discussion of this type of analysis).

People concerned with "bottom-up" product improvement have always been reluctant to accept "top-down" economic summaries. Conversely, when hearing about the inventions and ingenuity that will be used in product improvement, "top-down" analysts are likely to remark "there is no free lunch" resulting from product improvement 
and that in the end all costs can be fitted by simple correlations. Needless to say, we cannot resolve these differences in viewpoint in the present study and we therefore present both perspectives in the following sections.

\section{XI-1. Critique from a Manufacturer's Perspective of Any Simplified Model to Describe Cost vs Production-Level Correlations}

It is obviously desirable to have an understanding of the need for and possible level of external subsidies required to commercialize FC power plants. Both the purpose of subsidies and estimates of their needed magnitude are captured inadequately by a model based on traditional learning curves. For this reason, it is important to include proper qualifications concerning the value of the presentation and emphasize that the model results should not be taken too literally by anyone.

\section{XI-1.1. Subsidies are required just to get the user to try "riskier" new products.}

One manifestation of this issue is the fact that customers/users of a new product may require a higher rate of return than for existing products or services. The net effect of this is to lower the competitive price. Subsidies may be needed to provide the risk offset for customers evaluating a new product. Once the product has been established in the market place, the magnitude of the perceived obstacle would be reduced and the competitive price could be increased. This goal could also be accomplished by demonstration programs. However, in a manufacturer's experience, each user requires multiple demonstrations representing a range of user-specific potential applications to show that the overall risk associated with the project is in fact acceptable. The risks that users are concerned about typically include operations, maintenance, service-organization capability, performance over time, and longevity/stability of the manufacturer. 


\section{$\mathrm{XI}$-1.2. There is no single market clearing price for FC power plants.}

Although it is generally agreed that $1500 / \mathrm{kW}$ would be very attractive from the standpoint of maximizing market penetration, there are applications and situations where the competitive price is much higher (i.e. $\$ 2500-3000 / \mathrm{kW}$ ). Even for these premium applications, customers perceive risks associated with new technology. An important purpose of subsidies is to achieve access to a broad spectrum of potential users who gain experience with the equipment without taking undue risks. It is clear that premium-price applications are not factored into an economic analysis limited to cost reductions through increased sales.

\section{XI-1.3. The economic benefits to the customer/user of the FC power plant are in part due to new application concepts and to unique features of the FC power plant.}

Generally speaking, these benefits are not normally considered by users in making economic decisions. Subsidies could be used to induce sales until these benefits are well recognized and can be factored into the overall economic evaluation for establishing a fully competitive price. In addition, subsidies permit realization of societal benefits such as emission reductions which, while important, have no specific economic value that a particular user can readily capture.

From an analytical perspective, it is not clear how to interpret the cost function used for the analysis. The cost-improvement function results from a combination of product-focused $R \& D$ and manufacturing-process improvements. A representative example of cost reduction with production-level increase is illustrated in Fig. XI-1.1. Each technology may be expected to have its own characteristics based on its present status of development. In addition, the total cost to bring the technology to the market place would be some combination of product-focused $R \& D$ investment and purchase subsidies. 


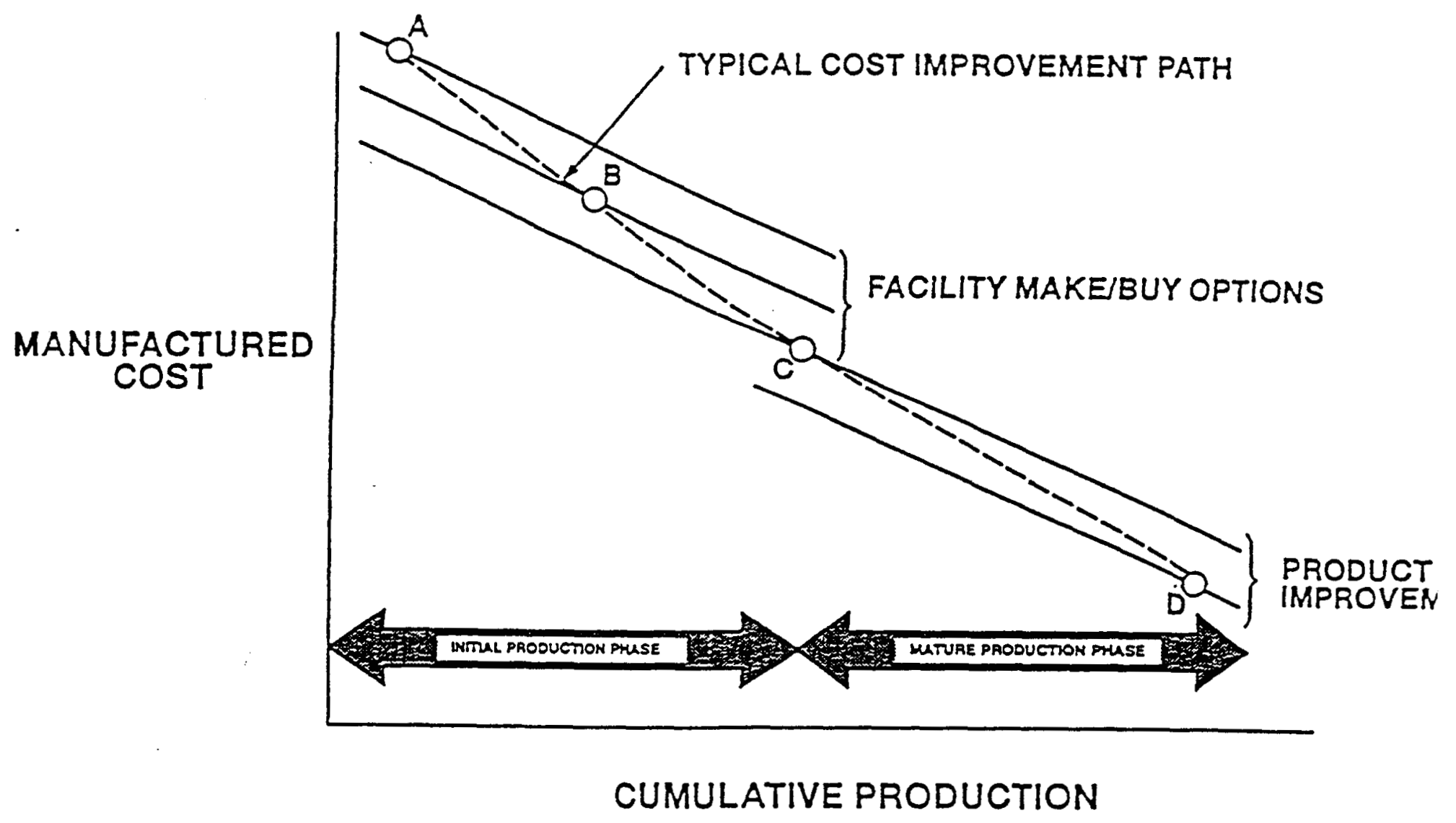

Fig. XI-1.1. A manufacturer's perspective on how manufactured costs relate to cumulative production. The points $A, B, C$, and $D$ correspond approximately to the initial cost level for a successful demonstration, the mid-range for make-buy options, early, and high-level commercial production. 
Consequently, the ability to estimate the total cost of bringing a technology to the market place will depend upon its relative deveiopment status.

In summary, while the questions of subsidy and the potential magnitude of it should be addressed, it needs to be done in a manner which brings out the high degree of uncertainty in the estimate and the totality of factors which influence it. Rather than try to estimate the subsidy, it might be appropriate to suggest that manufacturers working together with potential customers and an independent agency should establish subsidy requirements and the best approaches for determining the magnitude of a subsidy on a technology-by-technology basis.

\section{XI-2. The "Top Down" Perspective}

From the "top-down" perspective, the issue boils down to estimating a learning curve representing economies of scale before final designs and product improvement have been achieved. Projections to achieve cost reductions for developing technologies are always of doubtful accuracy because of the likelihood of unforeseen innovations or possible problems with reliability and field performance. Nevertheless, the following type of correlation has the advantage of fitting historically achieved cost reductions for a wide variety of technologies (see Sec. XI-6 for details).

The cost $c_{s}$ of a manufactured product per unit of product may be parametrically represented by the relation

$$
c_{S}=f(t) S^{b} / S=f(t) S^{b-1},
$$

where $f(t)$ is a decreasing function of time (because of innovation in manufacturing), $S$ the scale of product manufacture and $b$ an industry-specific constant parameter as manufacturing approaches technical maturity. Examples are $b=2 / 3$ for chemical manufacture and pipeline construction, $b=0.7$ for supertanker construction and $b=0.5$ for nuclear power-station complexes. A reasonable value for $\mathrm{b}$ will not be known for $\mathrm{FC}$ - 
system manufacture until after this industry reaches maturity. For the purposes of this preliminary estimation, we will assume $b \equiv b_{F C}=0.6$, i.e. a value intermediate between the known values for nuclear power-station complexes $(b=0.5)$ and chemical manufacture $(b=2 / 3)$.

If $c_{S}\left(t_{0}\right)$ is the unit cost at time $t_{0}$ with production scale $S$, then the cost ratio $R$ per unit of product output when the scale of manufacture has reached $10 \mathrm{~S}$ to that when the scale of manufacture was $S$ is given by

$$
R=\frac{c_{10 s}(t)}{c_{s}\left(t_{0}\right)}=\frac{f(t)}{f\left(t_{0}\right)} \frac{(10 S)^{b} /(10 S)}{S^{b} / S}=\frac{f(t)}{f\left(t_{0}\right)} \times 10^{b-1}
$$

We expect $f(t) / f\left(t_{0}\right)$ to be less than unity. Any estimates of this technology-innovation learning ratio must ultimately come from FC-system manufacturers. In the absence of needed first-hand information, we set this ratio equal to unity on the assumption that even the first satisfactorily operating FC-system with complete BOP will represent reasonably mature technology. Equation (XI-2.2) now becomes

$$
\mathrm{R}=10^{\mathrm{b}-1} \text {. }
$$

Using Eqs. (XI-2.1) and (XI-2.2) and $b=0.6$, it is shown in Sec. XI-6 that an FCsystem with a fair market value that returns a profit to the manufacturer and is priced at $\$ 4000 / \mathrm{kW}$ after 100 units have been built at the $200 \mathrm{~kW}$ per unit power level will require the additional construction of 1000 units to reduce the unit cost to $\$ 1590 / \mathrm{kW}$ with a fair return on investment. This process will involve a total external subsidy of about $\$ 120$ million if all of the systems are sold for $\$ 1590 / \mathrm{kW}$ while production scale-up is implemented. If the preceding estimates are arbitrarily applied to PAFCs, the total external subsidy to develop this competitive FC-system since initiation of development will ultimately reach the order of $\$ 750$ million (see the Sec. XI-6 for details). 
Another FC system considered in Sec. XI-6 is assumed to cost $\$ 10,000 / \mathrm{kW}$ at the 2-MW scale for the first unit. For $b=0.6$, the production of 100 of the $2-\mathrm{MW} \mathrm{FC}$ systems will reduce the system cost to about $\$ 1590 / \mathrm{kW}$ and require external subsidies of about $\$ 180$ million.

The preceding calculations and any other estimates not made by FC-system manufacturers are, of course, little more than highly doubtful, first-order, back-of-theenvelope numbers. Nevertheless, the conclusion appears reasonable that required additional external subsidies for commercially-competitive sales of the two specified FCsystems fall in the range $\$ 120$ to $\$ 180$ million. In the context of revolutionizing the international power-conversion markets and achieving U.S.-industry superiority in a potentially highly lucrative and competitive international market encompassing both the developed and developing parts of the world, the estimated requirements for additional total external subsidies are modest.

\section{XI-3. Sharing the Risks in FC-System Market Entries Between (i) FC-System Manufacturers, (ii) FC-System Purchasers and (iii) Interested Third Parties}

How should risk sharing be partitioned during the early, middle and late commercialization phases? What are formulas for equitable reward/risk ratios for the different participants? These are important public policy issues, which we consider to fall beyond the scope of our deliberations.

\section{XI-4. Public Benefits Anticipated Through FC-System Commercialization}

Enumeration of public benefits requires quantification of each of the following: (i) the value of cleaner local environments, (ii) the value of shorter transmission lines with dispersed power systems, (iii) the value of reduced $\mathrm{CO}_{2}$ emissions through higher efficiency in power conversion, (iv) the long-term benefits resulting from high- 
technology jobs and manufacturing opportunities and export opportunities, and (v) and the cost of avoiding the undesirable impacts on the U.S. economy by not commercializing FC-system technologies first.

The first two specified benefits can be quantified for particular locations in a specified utility system, as has been well demonstrated in a recent EPRI publication, 1 which shows that it is primarily the combination of cleaner local environments and reduced transmission and distribution costs which ultimately made the FC-systems (priced at or below $\$ 1500 / \mathrm{kW}$ ) less costly than advanced diesel generators. The third benefit is much more difficult to quantify because of its global nature and intimate connection with climate models. For our purposes, it is sufficient to note that macroeconomic approaches have been constructed ${ }^{2,3}$ for estimations of the societal costs of reduced $\mathrm{CO}_{2}$ emissions using "top-down" economic models. Quantitative comprehension of the fourth and fifth benefits are not available, require careful modeling of the U.S. and world economies and fall beyond the scope of these investigations.

\section{XI-5. Summary Statements on the Status of FC-Systems (cf. Table I-1)}

PAFCs have been used commercially and have performed reliably. Costs must be reduced as the result of further sales.

MCFCs are being constructed in demonstration units and are expected to perform as designed.

1 "Carbonate Fuel Cells and Diesels as Distributed Generation Resources - Economic Assessment of Application Case Studies at Oglethorpe Power Corporation," TR-102163, Project 1677-24, EPRI, Palo Alto, CA (October 1993).

2 A. S. Manne and L. Schrattenholzer, "Global Scenarios for Carbon Dioxide Emissions," Energy - The International Journal $\underline{18}$, 1207-1222 (December 1993).

$3 \mathrm{~W}$. Nordhaus, "The Economics of Greenhouse Warming: What Are the Issues?" in "Proceedings of the International Workshop on Costs, Impacts, and Possible Benefits of $\mathrm{CO}_{2}$ Mitigation," International Institute for Applied Systems Analysis. Laxenburg, Austria (1993). 
The limited field experience with tubular SOFCs has actually involved more complete field system tests than those for MCFCs. Costs will be reduced with further market penetration.

Planar SOFCs hold the promise of substantial cost reductions but are at earlier stages of development.

After the successful commercialization of PEMCs in stationary power systems, transportation applications may follow with more innovation.

The concurrent development of PEMFCs for both mobile and stationary applications is expected to benefit both types of systems, although there are important differences in these applications. For example, much shorter performance lives and much greater cycling rates are needed in mobile systems. The huge proliferation of PEMFCs for mobile systems is expected to reduce system costs rapidly. On the other hand, the stationary units are expected to cover a much wider power range than the mobile systems and will also have to meet the economical service life of 40,000 hours that is expected for other stationary FC entries.

\section{XI-6. Cost vs Production-Level Estimates for Hypothetical FC-Systems}

At a production level or scale of production equal to $S$, the total expenditures $C_{T}$ may be assumed to be given by a relation of the form

$$
C_{T}=f(t) S^{b},
$$

where $f(t)$ is a function of production level and hence of time $t$ that depends on the introduction of innovations and improved quality control, whereas b is taken to be a 
product-specific constant parameter. ${ }^{4-9}$ We will assume that $\mathrm{f}(\mathrm{t})$ is a constant $\equiv \mathrm{C}_{0}$ for a demonstrated FC-system technology in the absence of detailed manufacturing data. The cost per unit of output at production level $S$ is $C_{t} / S \equiv c_{s}$ and Eq. (XI-6.1) may then be rewritten as

$$
\mathrm{c}_{\mathrm{s}}=\mathrm{C}_{\mathrm{o}} \mathrm{S}^{\mathrm{b}-1} \text {. }
$$

For $c_{S}=\$ 5000 / \mathrm{kW}$ at $\mathrm{S}=100$ with $\mathrm{b}=0.6, \mathrm{C}_{0}=\$ 31,550 / \mathrm{kW}$; for $\mathrm{c}_{\mathrm{s}}=\$ 4000 / \mathrm{kW}$ at $\mathrm{S}=$ 100 with $\mathrm{b}=0.6, \mathrm{C}_{0}=\$ 25,240 / \mathrm{kW}$. Although innovation and product improvements are accomplished in discrete steps, we will approximate the real situation by assuming that $c_{s}$ is the continuous function of S specified in Eq. (XI-6.2). The rate of decrease of cost per unit of output with $S$ is then given by

$$
-\mathrm{dc}_{\mathrm{S}} / \mathrm{dS}=\mathrm{C}_{\mathrm{o}}(1-\mathrm{b}) \mathrm{S}^{\mathrm{b}-2}
$$

and the average cost per unit of output in raising the scale of production from the first unit to level $\mathrm{S}$ becomes

$$
c_{1 \rightarrow S}=\left[C_{o} /(S-1)\right] \int_{1}^{s} x^{b-1} d x=\left[C_{0} / b(S-1)\right] \times\left(S^{b}-1\right) .
$$

For $b=0.6$ with $S=100$, it follows that $\varepsilon_{1 \rightarrow S}=0.250 C_{0}$ as compared to $c_{100}=0.158$ $\mathrm{C}_{0}$.

\footnotetext{
4 See, for example, C. Marchetti, "Transport and Storage of Energy," Report RR-75-38, International Institute of Applied Systems Analysis, Laxenburg, Austria (1975).

5 S. S. Penner and L. Icerman, Non-nuclear Energy Technologies, Vol. II, second edition, pp. 110-113, Pergamon Press, London and New York (1984).

${ }^{6}$ A. R. Fusfeld, "The Technological Progress Function: A New Technique for Forecasting," in A Guide to Practical Technological Forecasting, pp. 92-105, J. R. Bright and M.E.T. Schoenman eds., Prentice-Hall, Englewood Cliffs, NJ. (1968).

7 M.T. Katzmen, "Paradoxes in the Diffusion of a Rapidly Advancing Technology: The Case of Solar Photovoltaics," Technological Forecasting and Social Change 19, 227-236 (1981).

${ }^{8}$ F. Krawierc, "Concepts of Learning and Experience in Developing Solar Technologies," Technological Forecasting and Social Change 24, 207-246 (1983).

9 World Bank Staff, "Learning, Technical Progress and Competitiveness in the Commuter Aircraft Industry: An Analysis of Embraer," The World Bank Industry and Energy Department, OSP, Washington, DC (June 1992).
} 
A ten-fold increase in production level to $10 \mathrm{~S}$ reduces the cost per unit of output from $c_{s}$ to $c_{10 s}$ with

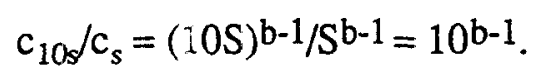

For $b=0.6$,

$$
c_{10}: c_{s}=10^{-0.4}=0.398 ;
$$

it follows therefore that the cost per $\mathrm{kW}$ will decrease from $\$ 5000 / \mathrm{kW}$ to $\$ 1990 / \mathrm{kW}$ and from $\$ 4000 / \mathrm{kW}$ to $\$ 1590 / \mathrm{kW}$ with scale-up of a factor of 10 . If this scale-up by a factor of 10 is accomplished by building 1000 additional FC-systems after construction of the 100th unit, then the average unit cost whiles scaling up for $b=0.6$ will be

$$
\bar{c}_{s \rightarrow 10 s}=\left(C_{o} / 1000 b\right) \times\left(1,100^{0.6}-100^{0.6}\right)=0.0849 C_{o}
$$

for $b=0.6$, i.e. the average production cost from 100 to 1,100 units is greater than the production cost of the 1100th unit by the factor $0.0849 / 0.06074=1.40$. If each unit produces $200 \mathrm{~kW}$, the production cost for 1000 additional units exceeds that of 1000 units of the commercial product by $(1000$ units $) \times(\$ 200 \mathrm{~kW} / \mathrm{unit}) \times(\$ 31,550 / \mathrm{kW}) \times(0.0849-$ $0.06074)=\$ 1.525 \times 10^{8}$ if the cost of the 100 th unit is $\$ 5000 / \mathrm{kW}$ or by $\$ 1.220 \times 10^{8}$ if the cost of the 100th units is $\$ 4000 / \mathrm{kW}$. In other words, the FC-system costing $\$ 4000$ to $\$ 5000 / \mathrm{kW}$ after 100 units have been built will cost $\$ 1590$ to $\$ 1990 / \mathrm{kW}$ for profitable sales after production scale-up by a factor of 10 , corresponding to the construction of 1000 additional units, and will require external subsidies of $\$ 122$ to $\$ 150 \times 10^{6}$ during the learning period that leads to the specified reduced unit costs of $\$ 1590$ or $\$ 1990 / \mathrm{kW}$.

For an entirely different 2-MW, hypothetical, non-existent FC-system, for which a first of a kind unit costs $\$ 10,000 / \mathrm{kW}$ and 100 additional units are constructed, the FCsystem cost is reduced by the factor $100^{b-1}=0.1585$ for $b=0.6$ according to Eq.(XI-6.4), i.e. the 100 th unit cost will be $\$ 1585 / \mathrm{kW}$. The average cost for the 100 additional plants is $\bar{c}_{1 \rightarrow s}=0.250 \mathrm{C}_{0}$ for $\mathrm{S}=100$ whereas the cost of the 100th plant is $0.1585 \mathrm{C}_{0}$. Thus, an external subsidy of $(0.250-0.159) C_{0}$ will be required on the average for each of the 100 
additional plants. In the present case, $C_{0}=\$ 10,000 / \mathrm{kW}$. Hence, the construction of 100 additional 2-MW units requires a total external subsidy of (100 units) $\times\left(2 \times 10^{3} \mathrm{~kW} / \mathrm{unit}\right)$ $\times(\$ 10,000 / \mathrm{kW}) \times(0.250-0.159)=\$ 1.82 \times 10^{8}$.

Of course, both our estimates of the same value of $b$ for the two plants and of the magnitude of $b$ are pure conjectures before the fact. Nevertheless, based on experience with other systems, the scale of the final estimates may well be reasonable.

We estimated in 1984 that about $\$ 450 \times 10^{6}$ had been spent on PAFC developments. ${ }^{10}$ Adding to this estimate the funds expended from 1984 to 1994 and then allowing for a further scale-up by a factor of 10 suggests a commercialization price tag of the order of $\$ 7.5 \times 10^{8}$.

Additional external subsidies in the range $\$ 120$ to $\$ 180 \times 10^{6}$ to reach economically competitive status for each of two FC systems appear quite reasonable in view of the tremendous commercial potential of economically competitive FC-systems for a wide variety of applications. Viewed from this perspective and the customary longterm economic outlook in countries such as Japan, external subsidies for the effective commercialization of FC-systems appear to represent a compelling national priority, as well as a highly desirable business venture for a company willing to trade large long-term returns for average short-term gains.

10 "Assessment of Research Needs for Advanced Fuel Cells" by AFCWG, 1984-85, S. S. Penner ed., Energy - The International Journal 11, 1-229 (1986); see, especially, pp. 1-3 and the article by A. J. Appleby on PAFCs, p. 13 et seq. 